\title{
De GGZ als systeem in wankel evenwicht : de geestelijke gezondheidszorg in relatie tot samengestelde gelijkheid
}

Citation for published version (APA):

Hamers, H. J. F. R. (1987). De GGZ als systeem in wankel evenwicht : de geestelijke gezondheidszorg in relatie tot samengestelde gelijkheid. [Doctoral Thesis, Maastricht University]. Rijksuniversiteit Limburg. https://doi.org/10.26481/dis.19870101hh

Document status and date:

Published: 01/01/1987

DOI:

10.26481/dis.19870101hh

Document Version:

Publisher's PDF, also known as Version of record

Please check the document version of this publication:

- A submitted manuscript is the version of the article upon submission and before peer-review. There can be important differences between the submitted version and the official published version of record.

People interested in the research are advised to contact the author for the final version of the publication, or visit the DOI to the publisher's website.

- The final author version and the galley proof are versions of the publication after peer review.

- The final published version features the final layout of the paper including the volume, issue and page numbers.

Link to publication

\footnotetext{
General rights rights.

- You may freely distribute the URL identifying the publication in the public portal. please follow below link for the End User Agreement:

www.umlib.nl/taverne-license

Take down policy

If you believe that this document breaches copyright please contact us at:

repository@maastrichtuniversity.nl

providing details and we will investigate your claim.
}

Copyright and moral rights for the publications made accessible in the public portal are retained by the authors and/or other copyright owners and it is a condition of accessing publications that users recognise and abide by the legal requirements associated with these

- Users may download and print one copy of any publication from the public portal for the purpose of private study or research.

- You may not further distribute the material or use it for any profit-making activity or commercial gain

If the publication is distributed under the terms of Article $25 \mathrm{fa}$ of the Dutch Copyright Act, indicated by the "Taverne" license above, 


\section{HUB HAMERS}

DE GEZ AIS SYSTEEM IN WANKELL EVENTICHT 
Het onderzoek werd uitgevoerd met behulp van data opgeslagen in het mental health case register, een gevalsregister voor de geestelijke gezondheldszorg voor zuldelijk zuid-Limburg. Dit register kon opgezet worden mede dankzif een subsidie van het ministerie van welzijn, Volksgezondheid en culturur. Voor enkele deelstudies werden in nauwe samenwerking met de afdeling Sociale Psychiatrie van de RUG gegevens uit het noordelljk register verwerkt. 


\section{Hub Hamers}

DE GE AIS SYSIFEM IN WANKEL EVEWIOHT

de geestelijke gezondheidszorg

in relatie tot samengestelde gelljkheid

pramotores: Prof. Dr. M.A.J. Rame

Prof. Dr. H. Philipsen

referenten: Prof. Dr. R. Giel

Prof. Dr. F. Sturmans

Prof. Dr. M.W. de Vries

CIP - gegevens Koninklijke Blbliotheek, Den Haag

Hamers, Hubertus Josephus Franciscus Renatus

De GGZ als systeem in wankel evenwicht : de geestelljke gezondheidszorg in relatie tot samengestelde gelijkheid / Hubertus Josephus Franciscus Renatus Hamers. - (S. 1. : s.n.). - Ill.

Proefschrift Maastricht. - Met lit. opg. - Met samenvatting in het Engels.

ISBN 90-9001924-3

SISO 614.1 UDC 364.65-056.37(492)(043.3)

Trefw.: geestell1ke gezondheidszorg ; Nederland.

Typewerk: L. v. Mameren

omslag ontwerp: $M$. Dente

Druk: B. Meerstad

(c) copyright $1987 \mathrm{H}$. Hamers

Alle rechten voorbehouden. Nlets ult deze ultgave mag worden verveelvoudigd zonder voorafgaande schriftelijke toesterming van de uitgever.

All rights reserved. No part of this publication may be reproduced or transmitted without the prior written pemission of the publisher. 

DEEL I: THEORETISCHE OVERWEGINGEN

1. Inleiding

2. Psychopathologie en verklaringsmodellen 17

2.1. Inleiding 17

2.2. Paradigmata m.b.t. psychische stoornissen 17

2.2.1. De medische optiek en haar varianten 18

2.2.2. Psychologische verklaringen 18

2.2.3. Enkele macro-optieken 19

2.3. De psychiatrische epidemiologie 20

2.3.1. De ecologische benadering 21

2.3.2. Stress en life-events 21

2.3.3. De bijdrage van het netwerk 22

2.3.4. Multifactorille bevindingen 23

2.3.5. Transcultureel onderzoek 23

2.4. Samenvatting en conclusies 24

3. Intermezzo: het menselijk handelen 27

3.1. Inleiding 27

3.2. Het sociale handelen als zingeving 27

3.2.1. Interactie als complexiteitsreductie 27

3.2.2. Typen saciaal handelen 28

3.2.3. Continulteit en verandering 29

3.2.4. Fricties in het sociale handelen 30

3.3. Zingeving en context 30

3.3.1. Civilisatie en psychische beleving 31

3.3.2. De staat als verzorger 31

3.3.3. Optimalisering on proto-professionalisering , 32

3.3.4. Stigmatisering en pijnlijkheid 33

3.4. Samenvatting en conclusfes 33

4. De geestelijke gezondheidszorg als matschappelijk

$\begin{array}{ll}\text { 4.1. } & \text { fenomeen } \\ \text { Inleiding } & 35 \\ \text { 4. } & 35\end{array}$

4.2. De (GGZ) geschiedenis in vogelviucht 36

4.2.1 Ongangsvormen in vroeger tijden 36

4.2.2. Het prille begin 36

4.2.3. Het ontstaan van differentiaties in het hulpaanbod 37

4.3. De huidige GGZ : 38

4.3.1. Beoogde doelen en functies 38

4.3.2. Centrifugale en centripetale krachten 39 
4.3.3. De eeuw ven het beleld: ook in de GGZ?

4.4. De GGZ als collectleve zingever?

4.4.1. De GGZ gevangen in de matschappelifke context

4.4.2. Vraag en anbod: over protoprofessionalisering

4.5. GGZ: hoe nu verder?

4.5.1. Het kernprobleem van de GGZ: chroniciteit

4.5.2. Verschulvingen in de invuliling van de doelsteling

4.6. Samenvatting en conclusies

5. Een brug: van theorie naar empirie 51

5.1. Inleiding 51

5.2. De GGZ als matschappelijke functie 51

5.2.1. De verschillen in de ruimte geminimaliseerd? 52

5.2.2. De verschillen in de tijd gemaximaliseerd? 53

5.2.3. De GGZ: voor welke groepen? 54

5.3. Samenvatting 56

DEEL II: EEN BESCHRIJVING: WERKWIJZE EN RESULTATEN

6. Een Psychiatrisch Case Register 57

6.1. Inleiding 57

6.2. Methode, techniek en mogelijkheden 57

6.2.1. Resistance, Privacy and Technology $* 1 \star \quad 59$

6.2.2. Record-Linkage, systemmanagement en dataprotectie 67

6.2.3. The Use of the Case Register in making Epidemiolo-

6.3. Samenvatting en conclusies 78

7. De regionale GGZ 79

7.1. Inleiding 79

7.2. Enkele interregionale vergelijkingen 79

7.2.1. GGZorg gepeild *3* 80

7.2.2. De GGZ in het noorden en het zuiden des lands in $1981 \star 4 * 93$

7.2.3. De geestelijke gezondheidszorg en haar rislicogroepen $\star 5 \star 107$

7.3. Samenvatting

113

B. De GGZ als organisatie 117

8.1. Inlelding 117

8.2. De mate van afsteming in de GGZ, 117

8.2.1. Het (on)bedoelde gebruik van meer GGZ-voorzieningen $* 6 * 119$

8.2.2. Kortdurende opnamen in PAAZ en APZ: wle naar war? *7* 125

8.3. Samenvatting 139

9. Behoefte an GGZ en samengestelde gelifkheld 141

9.1. Inleiding 141

9.2. Maatschappelijke kwetsbaarheid on aangemelde morbiditeit

9.2.1. De sociale en rulmtelifke spreiding van psychiatrische morbiditeit 
9.2.2. Behoefte an GGZ in relatie tot samengestelde gelifkheid

9.3. Samenvatting

10. 10.1 . Slotbeschouwing

10.2. De huidige GGZ

10.2.1. Als cultureel systeem

10.2.2. Als sociaal systeem

165

10.2.3. Implicaties vaor verder onderzoek

166

10.3. De toekomst van de GGZ

167

10.4. Samenvatting en conclusies

11. Samenvatting

* * de (co-)auteurs van de hier opgenomen pubicaties:

* $1 *$ H.J.F.R. Hamers, M.A.J. Romme M.W. deVries $\star 2 \star$ M.W. deVries, H.J.F.R. Hamers \& F. Sturmans *3* F.G. Brook \& H.J.F.R. Hamers

$\star 4 *$ H.J.F.R. Hamers \&.G. Brook

*5* H.J.F.R. Hamers \& G.A.M. Driessen

*6* H.J.F.R. Hamers, M.A.J. Romme G.A.M. Driessen

*7* H.J.F.R. Hamers, G.A.M. Driessen \& J.M.G. Lasker 


\section{VRRANIWOORDING}

Dit boek is opgebouwd uit twee "lagen". De eerste 1 aag bevat een sociologische optlek warin de plats van de geestelifke gezondheldszorg (GGZ) In onze samenleving op theoretische gronden angegeven wordt. De tweede laag is concreter van ard en 18 gevormd ult een reeks artikelen, warin de GGZ langs een drletal Invalshoeken empirisch beschreven wordt.

Dit betekent dat ten dele wordt gewerkt vanult en macro-gociologische optiek varin de GGZ als social en als cultureel subsytem (theoretisch) centrabl atat, mas ook dat ik mij-vooral in die onderdelen warin empirische resultaten gepresenteerd worden- zal bedienen van jargon, begrippen en theoriefragmenten zoals die in de sociale psychlatrie, in de psychologie en de soclologie als ondersteunende disciplines binnen het medisch domein ontwikkeld zijn. De concrete empirische beschrifving is gebaseerd op mifn practisch georienteerde onderzoeksmatige bezigheden gedurende de afgelopen jaren. Mijn interesse naar instituties als b.v. de GGZ bezien vanult een sociologische optiek was al gewekt tijdens mijn soclologiestudie. De voorwetenschappelijke aanzet tot die interesse wordt hieronder met behulp van twee prive "petites-histoires" gegeven.

"Direkt na de eerste wereldoorlog trok als een van de vele migranten in die periode een vlaming uit de omgeving van Maasmechelen naar de stad Masisticht war hij als fabrieksarbelder aan de kost kon komen. Hij trouwde met een mastrichtse 'lowermiddle class' vrouw, op het moment dat deze dacht verder als oude vifster door het leven te moeten gan. Het echtpar kreeg twee kinderen: de jongste was mijn vader. Mijn opa was een zeer goedmoedig en zachtaardig mens. Mijn oma was in har eigen ogen beneden haar stand getrouwd. Ze herinnerde haar man daar regelmatig an. Deze egolistiache, weinig liefdevolle en contactarme vrouw probeerde federeen in haar omgeving voor haar karretje te spannen. Daarbij was ze zieke$11 j k$ : een gegeven dat zij, zoals u al verwachtte, te pas en te onpas benutte. Hif had zijn gehele leven angstdromen over een voorbije loopgravenoorlog. Het gezin werd door de buurtbewoners als zeer gesloten gekenschetst."

"Eind zeventiger jaren verhuilde de kleinzoon van deze man ls net afgestudeerd socioloog vanuit zijn unfversiteitsstad Nijmegen nar Mastricht on dar zijn matschappelijke loopbaan te starten. Op dat moment was hif even oud als afjn grootvader ten tijde van diens migratie. De kleinzoon was echter al getrouwd. $21 j n$ vrouw was an de sociale academie afgestudeerd en had een baan. Het echtpar had twee jonge kinderen."

Ik, de kleinzoon, lijk wel een beetje op mijn grootvader, maar afgezien van een "migratie' op dezelfde leeftijd zijn ex niet veel overeenkomsten.

Wat is er voor de lezer nu belangrifk an deze twee geschiedenlssen? 
Het belangrijke wan deze "petites-histolres' Ifgt in het gemeenschappelifke, in de overeenkonsten, maar ook in de verschillen. Als ik die hieronder 11 angeven, dan zal $1 k$ daarbij interpreterend mijn weg moten zoeken. Afgezien van deze "methodologische" beperking dient de lezer mij te verontschuldigen voor het gegeven, dat deze interpretatle door de overlevering gekleurd zal zijn.

De verschillen tussen beide geschiedenisgen zijn zeker op het eerste gezicht groot. Zo verschilen de 'Ilfe-events' in intensiteit. Materiee 1 zijn de omstandigheden sterk veranderd, er is een groot verschil in opleidingsniveau aanwezig en is het eerste gezin al als gesloten getypeerd dan is mijn gezin open te noemen. Echter, plaatsen wij beide geschiedenissen in hun eigen tijd, in de juiste context, dan blifken de verschllen anzienlifk kleiner. Wat dan het meest opvalt, is dat er sprake is van een wezenlijk andere culturele beleving, een andere zingeving om de ondervonden problemen het hoofd te bieden.

Impers, waren wif tifdens belde geschiedenissen met ons researchinstrumentarium a anwezig geweest, dan zouden de metertjes bij tijd en wifle ultgeslagen zifn. Toen echter, kenden de mensen de begrippen psychische stoornis, neuroticisme, etc. niet. Oh ja, gekken en zwakzinnigen wel, mar verder gold de uitdrukking dat "leder huisje zijn elgen kruisje had". Het salllante verschil tussen nu en toen is dus het wezenlijk inders omgan met in wezen dezelfde problemen: toen mestal lijdzaam, terwijl nu een vertaling en een herdefiniëring. plaatsvindt op een zodanige wijze dat het mogelijk wordt oplossingen aan te reiken. In de vorm van het natuurwetenschappelifk model -althans meer of minder geslaagde imitaties daarvan- is het rationalisme uitgebreid tot het dagelifks leven.

Heden zijn er steeds meer mensen te vinden die belevenissen trachten te thematiseren om op die manier $z$ in te geven aan een leven dat per definitie moeilijk is. Vroeger werden de dingen als door God gegeven beleefd, warbij de belevingen niet geproblematiseerd behoefden te worden. De zingeving werd gezocht in een andere overheersende ideologle: in het Mastricht van mijn grootvader was dat die van het Rijke Roomse Leven. Hoewel deze wijze van zingeving zeker niet verdwenen is, wordt nu door velen een andersoortige oplossing voorgestaan. Dlt versehil levert conseqenties voor instituties met behulp warvan mensen het sociale leven vorm geven.

De lezer kan tegenwerpen dat de verschillen tussen beide geschiedenissen voortkomen utt de anwezige klasse- en opleidingsverschillen. Men vergeet dan echter dat het opleidingsniveau (en de soclaal-economische situatle) over de gehele populatie sterk verbeterd is en in relatief opzicht de referentles voor de actores niet veel veranderden. Belangrijket zijn de navolgende constateringen. De technische mogelifkheden en daarmee gepaard gaande mogelijkheden tot communcatie en informatie zijn inds mijn grootvaders-tijd enorm veranderd. Als ik als onregelmatige consument van televisieprogramma's op een w1lekeurlg moment het scherin bekijk, dan wordt mij uitgelegd wat een 
fobie is: dat dit niets buitengewoons is en dat er wat an te doen valt. Als $1 k$ als een onregelmatige lezer van populaire bladen eens in de Libelle of de Margriet blader, dan kom ik verhalen van (psycho-) therapeuten tegen die als blijde boodschap bremgen dat er voor bljna alles wel een ver- of een oplossing in het verschiet $1 \mathrm{gt}$.

$\mathrm{U}$ hoort mif op dit punt geen wardeoordeel uitspreken: wel constateer ik dat wij met zijn allen de samenleving zodanig georganiseerd hebben, dat wj in sterke mate geprotoprofessionaliseerd *1* zIjn en dat aangaande (vaak heel simpele) dingen die hun oorsprong in het dagelijks leven hebben.

Mijn theoretische overwegingen zullen over de interrelaties tussen de GGZ en het dagelifkse leven gan. Deze interrelaties hebben invloed gehad op de ontwikkeling van de GGZ als institutie; op de organisatie en op het gebruik ervan.

Vanult een soclologische optiek kan de GGZ als een sociaal subsysteem gezien worden, dat in onze samenleving ingebed 1s. De GGZ kan echter ook als een cultureel subsysteem opgevat worden, waarin verklaringen over psychische stoornissen zijn opgeslagen: verklaringen die anleiding kunnen zifn tot behandelingen van psychische stoornissen, mar ook verklaringen die het dagelijkse gedrag kunnem beinvloeden. Hiermee is dan al angegeven dat de GGZ als cultureel subsysteem zich uitgebreider manifesteert dan als social subsysteem. De term soclaal subsysteem is gereserveerd voor éen specifieke werksoort verdeeld over een (beperkt) aantal voorzieningen.

Met het bovenstaande heb $1 k$ gepoogd een eerste algemene leidraad voor deze bundel vast te stellen, warbij nu al aangetekend kan worden, dat de GGZ niet als vanzelfsprekend tot stand is gekomen. Kort en bondig zou $i k$ de leidraad als volgt lilen formuleren: de betekenis en de functie van de GGZ als institutie $\star 2 \star$ kan ons veel leren over de stand van zaken in de samenleving. Oradat de GGZ als een soclale verdichting van een cultureel subsysteem op te vatten is, kan kennis van de GGZ ons "op afstand' lets leren over hoe wij-als individu en als collectief- vormgeven a an het (samen)leven dat behalve zijn prettige momenten nu eenmal ook zijn problemen en tegenslagen kent. Toch dient er nog een tweede voor-wetenschappelijke constatering genoemd te worden: niet leder mens blijkt in dezelfde mate gelukkig. Enerzijds omdat het er sterk op lijkt, dat de prettige en de onprettige dingen des levens nlet gelijkelijk verdeeld $z i j n$ en er en samenhang aanwezig lifkt tussen deze verdeling en de positie die matschappelijk ingenomen wordt; anderszijds heeft niet leder mens in dezelfde mate mogelifkheden om problemen te liff te gaan. Om toch tot een redelijke, min of meer rechtvardige verdeling van het "geluk" te geraken kent ons soort samenleving -op groepsnivo- compensatiemechanismen; or dit fenomeen te benoemen wordt de term "samengestelde gelijkheid' $\star 3 \star$ gebruikt. Daarmee zif kort de hint gegeven, hoe ik met de ondertitel van deze bundel denk om te gaan. 
HOOFDSTUK 1

\section{INLEIDING}

De empirische resultaten die in deze bundel bijeengebracht zifn, hebben betrekking op practische vraggtellingen: hoeveel personen komen met de geestelijke gezondheldszorg (GGZ) in aanraking" "hebben verschillende GGZ-voorzieningen te onderscheiden functies', etc. Een gebruikelijke term voor dit soort vraggtellingen is gezondheldszorgonderzoek (GZO).

In de afgelopen jaren groeide bij mij een zekere irritatie ten anzien van de inhoud van deze term. Ze suggereert een tegenstelling tussen fundamenteel en toegepast onderzoek, terwijl een dergelijk onderscheld in zekere zin kunstmatig is. De overgang van de ene vorm nar de andere verloopt vloeiend (Albinsky, 1978). Bovendien kunnen beide vormen van onderzoek (en wetenschapsbedriff) niet zonder elkar; de ene bestaat bij de gratie van de andere. De resultaten van toegepast onderzoek kunnen bljvoorbeeld gebruikt worden om meer algemene wetmatigheden en trends in de samenleving in beeld te brengen (Aakster, 1981 ).

Vanuit de veronderstelling dat de GGZ als een sociaal en cultureel subsysteem beschouwd kan worden (Fabrega, 1982; Kleinman, 1982) met een functionele imbedding in de samenleving heb ik en antal deelstudies bijeengebracht. Het probleem van deze optiek is dat de samenleving niet rechtstreeks een functie presenteert, die vervolgens ingevuld wordt; de institutie $* 1 *$-eenmal rudimentair ontstaan- is in zichzelf dynamisch, verandert de samenleving en roept -evenzeer als zijer anderzijds afhankelijk van is-daarmee functies op die zij kan vervullen. Dus, war geen mogelijkheid is om bepaalde vormen van gedrag als te behandelen psychische stoornissen te definierren -dus war geen GGZ als cultureel subsysteem anwezig is- daar zal geen manifeste behoefte an deze matschappelijke functio bestan. Dit $\mathbb{I}^{\mathrm{s}}$ niet ondat er geen psychische stoornissen zouden $z \mathbf{f}$, maar omdat de vertaalsiag van problemen en gedragingen nam psychiatrie niet gemakt kan worden. In cultuur $* 2 * 11 \mathrm{gt}$ de definitie besloten van wat als psychische stoornis gezien kan worden.

In deze bundel zal ik eerst bespreken hoe psychopathologle 'verklaard" wordt. Vervolgens wil ik als intermezzo het social handelen vanuit een soclologische optiek bespreken, wardoor $1 \mathrm{k}$ kan angeven welke functie de geestelijke gezondheidszorg in ons soort samenleving dient te vervullen. Een sociaal subsysteem is echter niet alleen te beschrijven vanuit een puur functionele invalshoek; daarom behandel Ik de structuren die door de tijd heen groeiden en die in sterke mate de huidige GGZ vorm hebben gegeven. 
Uit deze theoretische overwegingen komen en antal hypothesem naar voren, die in het tweede deel van deze bundel getoetst zullen worden. Daarbij zij angetekend dat alleen die hypothesen opgesteld zijn, die voor toetsing met het anwerlge empirisch material in anmerking komen; in dat opzicht heb $1 k$ een beperking moeten aanbrengen.

In de bundel heeft het empirlsch deel in grote lifnen langs drie invalshoeken vorm gekregen. Na een methodisch hoofdstuk, warin ik het gebruikte onderzoeksinstrument beschrijf, geef ik in de eerste plaats weer hoeveel mensen net de GGZ in contact komen; hoe deze mensen over de verschillende voorzieningen verdeeld zijn en beschrijf Ik akele kenmerken van de patikntenpopulatie. Deze erste beschrijving heeft grotendeels betrekking op de GGZ in een tweetal regio"s.

In de tweede plaats wil 1 k het functioneren van de GGz vaststellen an de hand van de populatle die door dit social subsysteem bediend, behandeld of verzorgd wordt. Op die manier kan ik de werking van de GGZ als een organisatorisch subsysteem beschrijven.

In de derde plats laat ik zien welke behoefte an GGz manifest is geworden. Deze behoefte kan ons lets leren over maatschappelijke levensomstandigheden van subpopulaties; omstandigheden die wellicht samengan met een verhoogd risico voor het krijgen van psychische stoornissen.

Uiteraard pretendeer lk hier nlet, dat ik met de gepresenteerde emplrische studies de gehele GGZ beschrijven kan.

Deze bundel is als volgt opgebouwd: deel I dient beschouwd te worden als de theoretische achtergrond van waruit ik de empirie bekijk, terwij1 deel II de feitelifk empirische beschrijving van de GGZ bevat. Na dit inleidende hoofdstuk worden in hoofdstuk 2 enkele paradigmata -noodzakelifkerwifs zeer kort- met betrekking tot het ontstaan van psychische stoornissen besproken. In datzelfde hoofdstuk worden vervolgens enkele relevante bevindingen van de psychiatrische epidemiologie beschreven. Het daaropvolgende hoofdstuk geeft een soclologitche wisle op het (afwijkend) menselijk handelen en levert darmee de bouwatenen om in theoretisch opzicht de "plats" van de GGZ in de samenleving an te geven. Deze aanzet krijgt in het vierde hoofdstuk eon noodzakelijke anvuliing door de GGZ in zijn ontwikkelingsgang en in zijn huldige verschijningsworm te beschrijven. In hoofdstuk 5 breng ik de werschillende theoretische overwegingen en theorleframenten bif elkar: van daeruit worden een antal in deel II te toetsen hypothesen geformuleerd.

Deel II bevat empirische deelstudies betreffende de GGz; dit deeI bestat in hoofdzak ult en negental afzonderlijke publicaties (een zestal zljn reeds eerder verschenen -paragrafen $6.2 .1,6.2 .3 ., 7.2 .1$, 7.2 .2 .7 .2 .3 . en 8.2 .1 - en een drietal zullen nog verschijnen -paraBrafen $8.2 .2 ., 9.2 .1$. en $9.2 .2-$ ). 
In het eerste hoofdstuk van deel II -hoofdstuk 6-wordt de gekozen methode beschreven en verantwoord. Hoofdstuk 7 bestaat uit enkele interreglonale vergelijkingen; vergelijkingen tussen de reglo zuide$1 i j k$ Zuid-Limburg en een regio ter grootte van een middelgrote gemeente in het noorden van het land. Ten behoeve van dit hoofdstuk zijn gegevens uit het 'zuidelijk' en het 'noordelifk" register verwerkt. Het volgende hoofdstuk ( 8 ) bevat de beantwoording van organisatorische vraagstellingen. Het laatste emplrische hoofdstuk (9) omvat material over de behoefte an GG2 vanult verschillende subpopulaties.

In hoofdstuk 10 wordt aangegeven of, en zo $\mathrm{fa}$, in hoeverre de theoretische concepten en beschrifuingen overeenkomen met het emplisish werk. Er worden enkele lifnen voor de toekomstige GGZ uitgestippeld en er worden aanbevelingen voor nader onderzoek gedaan. Hoofdstuk 11 tenslotte bevat een samenvatting. 


\section{PSTCHOPATHOLOGIE BN VERKLARINGSMODELLWWN}

\subsection{Inleiding}

Het medisch systeem als theorie, als duiding van een deel van de werkelijkheid is een cultureel systeem. In de toepassing is het een social systeem. In ledere samenleving zien we dan ook een elgen medisch systeem, in cultureel en in soclaal opzicht. Of zoals Fabrega het stelt: "... In a basic sense the type of soclety and its mode of linkage to the physical environment .... are what condition (in certain respects, determine) the kinds of medical problems that exist in a society. It is the set of medical problems that exist in a society that constitute the target of the society's theory of 111 ness and medical care systems. The latter phenomena, which one may term the cultural and soclological aspects of medicine "are what in turn condition (in certain respects, determine) how these problems are construed and handled." (Fabrega, 1982, p.29). Een analoge opvatting is aan te treffen bif Kleinman (1980): hij formuleert een model waarmee medische systemen begrepen kunnen worden als culturele systemen warbinnen ziekte geschetst wordt in een symbolische vorm van het sociale leven. In het sociale systeem wordt theraple bedreven; de behandeling vindt plaats in specifieke instituties met hun eigen normen, warden, rollen en relaties (zie ook Kleinman, 1982).

De essentie van deze redenering is dat de gezondheidszorg als onderdeel van een groter cultureel systeem mede bepaalt wat individuen als zlekte ervaren en dus ook behandeld wensen te zien. Szasz (1961), I11ich (1976) en Lasch (1977, 1982) beweren dat de gezondheidszorg dit soort opvattingen zou determineren. Dit extreme standpunt deel ik niet o.a. op grond van informatie vanuit anthropologisch en cultureel-psychiatrisch onderzoek.

In dit hoofdstuk geef ik an vanuit welke disciplines wat als psychische stoornis gedefiniegd wordt. Hoewel blijkt dat er een groelende consensus ten anzien van de definitie is, nemt de variatie wat betreft de verklarings-en (be)handelingsmodelien zeker nlet af.

\subsection{Paradigmata met betrekling tot psychische stoornissen}

'Gekte' platst de wetenschap voor wele vragen. Dat die vragen nog niet beantwoord zijn, moge blifken uit de vele disciplines die zlch er mee bezig houden. Desondanks kan, in wetenschappelijk en in toegepast opzicht, een voorultgang geconstateerd worden. Echter van de psychiatrie, beter van de verzameling kern- en hulpdisciplines, mag niet eenzelfde resultat verwacht worden als van de overige medische specialismen. Het object van de psychiatrie lmmers dient in we- 
tenschappelifk en in toegepast opzicht eerder 'gedragsmatig' dan "technisch" benaderd te worden.

Ten slotte, het geheel en al ontbreken wan een min of meer gezamen$11 \mathrm{kk}$ paradigma, warmee een onderzoeks- en behandelkader wordt angerelkt, heeft gevolgen voor de structuur en de organisatie van de GGZ.

\subsubsection{De medische optiek en har varianten}

In de psychiatrie $11 \mathrm{jkt}$ de klinische psychiatrie het sterkst ontwikkeld. Ze ls ontsaan vanuit een traditioneel naturwetenschappelijk (medisch) model met een mechanistische inslag en bepaalt in sterke mate het (klinlsch) gebeuren rond gekte. In de klinische psychiatrie wordt gewerkt vanult en nosologische gedachtengang warbif het complex an symptomen en syndromen gezien wordt als een ziektekundig (analoog aan de somatische geneeskunde) verklaringsmodel warin het probleem van de patient geplaatst wordt.

In de cocile psychiatrie zijn in grote lijn een drietal stromingen te onderschedden: de eerste gat uit van ziekte en is in die zin te bezien als een in soclale situaties toegepast kinisch handelen (en naar analogie daarvan in research terug te zien), terwijl de tweede stroming meer social epidemlologisch gebrienteerd is en als onderzoek sterker in de sociologie dan in de psychiatrie terug te vinden 1s. De sociaal-psychiatrische studies binnen de eerste stroming zijn opgezet vanult een medisch madel met daaran toegevoegd een aantal soclologische en psychologische (individuele) variabelen. Ik spreek over een opzet vanult een medisch model omdat de ziekte, de symptomen, de syndromen voorop staan; ook in de te verifieren causaliteitspatronen.

De social-psychiatrische studies binnen de meer soclologisch georienteerde stroming stelt sociale problemen, veranderingen, e. d. voorop en bekifkt deze met het oog op mogelijke consequenties voor de geestelijke gezondheidstoestand van individuen (o.a. Cassel \& Tyroler. 1961; Casse1, 1976). Stokols (1986) verwijst naar Cassel (1964) om an te geven, dat in deze richting de opvattingen verschoven zijn naar en meer "holistic, soclal-epldemiologic perspective".

De derde en meest radlcale vorm van sociale psychlatrie is te vinden binnen de ant $1-p s y c h i a t r i e ~ * 1 *$ in zifn diverse varianten. Binnen deze stroming wordt de schuld van alle (psychiatrische) ellende primair gelegd in verstoorde relaties en naar gelang het niveau (d.w.z. gezin - kleine groep - matschapplj) van een hogere orde wordt, lijkt de radicaliteit - wat betreft de te ondernemen acties- toe te nemen.

\subsubsection{Poychologische verklaringen}

Vanuit de psychologie is een belangrijk deel van het instrumentarium, dat nodig is voor het psychiatrisch epidemiologisch onderzoek ontwikkeld. De psychologen leveren ter ondersteuning van zowel de behandelpractifk als de research een groot deel van het (diagnostisch) onder- 
zoek. In het onderstande heb $1 k$ me beperkt tot drle hoofdstromingen, die momenteel in de behandelpractljk gebruikt worden. Fen ander deel van de "psychologle" zal ik in de paragraaf over 'stress en lifeevents" behandelen.

De eerste en audste hoofdstroom lis de psycho-analyse; deze atroming heeft als geen andere andacht voor het onbevustie em het driftmatige In het gedrag van mensen. Er wordt daarbij gepoogd persoonlifke prom blemen te benoemen als botsingen antstaan tijdens de ontwikkeling van een persoonlifkheid tussen onbewuste driften enerzijd en de realitelt die hieraan niet altijd tegemoet kan komen anderzifds. Hoewel de invloed van de psycho-analyse niet onderschat mag vorden -zijn de directe gevolgen op de huldige behandel- en researchpractijk minder groot dan op het eerste gezlcht zou 1 ffken. De psycho-analyse heeft wel invloed gehad op de bredere stroom van de psycho-dynamische behande1- en research-practijk warin de verwerking van enoties binnen het individu een centrale plats inneemt. Bovendien $z i j n$ verschillende nieuwere therapievormen in meer of mindere mate uit de psycho-analyse voortgekomen.

Een tweede hoofdstroom vormt de humanistische psychologle. Deze gat uit van een optimistisch mensbeeld en ziet de mens in sat tot een grote mate an zelf-actualisatie, wardoor ook de relatie met $z 1 j \mathrm{n}$ omgeving versterkt wordt. In de eerste decennia na de tweede wereldoorlog heeft deze vorm van behandeloptlek (b.v. de rogerianse theraple) een grote vlucht genomen. Voor epldemiologlsch onderzoek heeft deze richting weinig opgeleverd, dit in tegensteling tot de derde stroming.

De derde hoofdstroom, de leertheorie, gat ervan uit dat alle gedrag -ook onaangepast, afwijkend gedrag- (aan)geleerd is en dus ook door middel van een (af)leerproces - i.c. gedragstherapie- te veranderen is. Zeker anvankelijk zette deze stroming zich aterk af tegen de twee voorafgaande, in het bijzonder tegen de psycho-analyse. De kracht van de leertheorie in practische zin is daarin gelegen, dat er vanuit deze theorie kortdurende theraplevormen ontwikkeld konden worden. En hoewel met het effectonderzoek een begin is gemalkt blinnen de tweede hoofdstroom, werd deze vorm van onderzoek binnen deze derde stroming verder uitgebouwd.

\subsubsection{Enke le macro-optleken}

Van oudsher staat binnen de soclologie het gedrag van individuen in een groter geheel cemtraal; dammee werd al vroeg het afwljkend gedrag als vraagstelling benoemd. Eigenlijk formuleert de sociologie de vraag andersom: hoe komt het dat de samenleving als geheel functioneert en in de $t$ ijd een min of meer stablel karakter heeft, terwifl deze opgebound is met behulp van het gedrag van vele indlviduen. Deze vragstelling verklaart de sociologische interesse in gedrag dat deze stabilitelt kan bedreigen.

Vanuit een soclologische optlek heeft afwijkend gedrag twee aspecten 
die enerzljds elkams tegenpolen zijn maar anderzijds moeilidk los van elkar gezlen kunnem worden. Ult het eerste aspect komt de volgende vrag, 0.a. door Durkheim en Parsons geformuleerd, naar voren: hoe krfJgt de samenleving het klaar enerzijds het ontsian van afwijkend Bedrag in omvang te beperken en anderzljds het bestaande afuljkende gedrag 'reg te organiseren'? $* 2$ *

Binnen het tweede aspect wordt afwifkend gedrag als een positieve factor in de samenleving gezien; het afwijkend gedrag zou er op zifn minst ten dele toe bijdragen dat de samenleving als geheel verandert. Wellicht kan zelfs gesteld worden, dat er t.8.v. (aanvanke1ijk) afwijkend gedrag nieuve gedragsatronen ontstaan wardoor de samenleving als geheel wellgwar verandert, mar warbif tegelifkertijd voor de samenlevlng nleuwe, andere mogelijkheden ontstan. Een ander pluspunt is dat afwijkend gedrag bij anderen en groepsversterkend effect heeft, wardoor het samhorlgheidsgevoel stijgt.

Hoe wif als matschappij omgan met afwljkend gedrag kan ons dus veel leren over de tand van zakem in een samenleving. Hoe we met afwijkend gedrag omgaan wordt zichtbaar als we kijken velke instituties een atabiliserende functie hebben en welke instituties tot taak hebben het afwijkende gedrag in voorspelbare banen te leiden. Door de institutie te gchetsen kan de matschappij in har ontwikkeling, als het ware in deze instituties gesplegeld, zichtbaar gemakt worden.

Wetenschappelifk heeft het bovenstaande vorm gekregen in sociologische onderzoekingen warin sociale problemen en de daaruit voortvloeliende matschappelijke consequenties bezlen worden.

\subsection{De paychiatriache epidemiologie}

Na deze umiere inventarisatie van paradigmata - in de psychiatrie, psychologie en sociologie-volgen hieronder verschillende practische benaderingen in de dagelijkse research.

De psychiatriache epidemiologie heeft door de tijd heen altijd hulp gekregen van gedraggwetenschappen als met mame de sociologle, de psychologle en de culturele antropologle. Hoewel de sociale epidemiologle noolt expliciet als theorle in een toetsbare vorm ten behoeve van de psychlatrie is opgezet, komen aspecten hiervan o.a. in de soclale cologie an de orde, mar dan worden de relaties op geaggregreerd niveau vastgesteld. In de psychiatrische epldemiologle daarentegen onderzoekt men gewoonlifk relaties op indluidueel niveau. De term psychiatrische epldemlologle is de parapluie voor de rijkdom aan empirische bevindingen over frequentie, apreiding en ontstan van psychopathologie.

Als if bezien hoe 'gekte" geoperationaliseerd wordt in het tegenwoordige (bevolkings)onderzoek, dan valt een zeker pragmatisme op: de criterla van 'cageness' zijn alle op de een of andere manier afgeleid van wat hulpverleners in de GGZ -of traditioneler geformuleerd, wat psychiaters- als te behandelen stoornissen zien (zie o.a. Wing a.., 1977) 
Oudere case-finding strategledn waren meestal gebaseerd op gelnstitutionaliseerde patientenpopulaties. Zo zijn er vele studies nar sprelding van psychlatrische opnamen over de populatie ultgevoerd.

\subsubsection{De ecologiache benadering}

Hoewel de fundamenten van deze benadering door quetelet zifn gelegd en Durkheim hlerop als eerste verder kon bouwen (o.a: met zijn onderzoek nat de spreiding van aulcides), is deze methode in het Chicago van de Jaren twintig volledig uitgebouwd met name onder leiding van Park en Burgess. In de door hen als theorle gepresenteerde opzet zijn behalve enkele darwinistische trekken ook theorlefragmenten van Durkheim te zlen (Nelissen, 1972; Bosma, 1975a). Men constateerde dat diverse vormen van sociale problemen volgens bepalde patronen over een gebled verspreid waren. Dit patroon heeft men -voor verschillende vormen van sociale problemen zoals sulcides, criminaliteit en opnamen in psychlatrische ziekenhuizen- in vele steden teruggevonden. Daarbif bleken de meeste problemen voor te komen in de centra van de steden: de problemen namen concentrisch vanuit het centrum naar de rand van de stad af (Haffner a., 1965; Wilken, 1973b; Srole e.a., 1978 en Faris D Dumam, 1939). In Rotterdam biljkt dat buurten die gekenmerkt worden door veel psychiatrische opnamen eveneens gekenmerkt worden door andere soclale problemen (Verdonk, 1979). Ook in Nijmegen blijkt een rulmtelijke concentratie van psychiatrische opnamen voor te komen (Bosma, 1975b). Drop (1979) onderzocht de spreiding van afwifkend gedrag (o.a. psychiatrische opnamen) waarbij de gemeente als aggregatienfveau fungeerde.

De a anvankelijk bewezen geachte hypothese dat de fysieke en sociale omgeving een belangrifke etiologische factor vormt in het ontstaan van psychische stoornissen wordt later ideologisch (Wilken, 1973a), maar vooral methodologisch (Dunham, 1965), sterk becritiseerd. De sociale ecologie als theorie is danook geheel verlaten. Ook zijn populariteit als onderzoeksdesign is afgenomen, hoewel het zeker nog gebruikt wordt (behalve mijn, in hoofdatuk 9 te presenteren, onder zoek o.a. zeer recent in Mannheim door Weyerer e.a. 1987) *3*.

Toch heeft de ecologische methode grote voordelen wat betreft uftvorbarheid $* 4 *$ en het genereren van hypothesen. Echter, dit type design is behept met een methodologische ongelukkigheid, $n .1$. het punt van de 'ecological fallacy'*5*.

In de komende paragrafen zulien verschiliende onderzoeksoptieken besproken worden, warbij gebruik gemakt wordt van gegevens op Individueel en niet op geaggregeerd niveau.

\subsubsection{Stress en life-events}

Howel het begrip atress uit de fysiologie afkomstig is, is het als concept in het psychologisch en het psychiatrisch-epidemiologisch onderzoek ingeburgerd. Een vorm van onderzoek richt zich op 
stressoren warvan if in onze atedelifke omgeving last zouden hebben. Voor ons is echter het onderzoek in de psychiatrische epidemiologle nar 'atregsful 1 ife-events' van meer belang. Het blifkt imners dat bedrelgende gebeurtenissen in het leven telkens een verband hebben met diveree aandoeningen, hetzij psychische hetzij somatiche. Echter, omtrent de etlologlsch rol van ife-events is er nog geen consengus berelkt. Dohrerivend (1986) geeft een vifftal te testen hypothesen, warbij er twee extremen over de te toetsen verklarlngachema's te onderschelden zijn. De eno verklaring leert dat persoonlijkheldakenmerken pathologle tot gevolg zouden kunnen hebben, wardoor 'Life-eventa' zouden optreden. De andere verklaring stelt dat soclale omstandigheden, zoals het antal (onplezierige) gebeurtenissen an gebrekklge sociale steun, de pathologie zouden veroorzaken. $\star 6$ *

Tot slot moet in deze paragraaf gerefeerd worden aan theorievorming en onderzoek warbij psychologische consequenties van (herhalde en oncontroleerbare) stresserende gebeurtenissen bezien worden. Dit onderzoeksveld is te typeren met het begrip 'learned helplessness" warover seligman (1975) zegt: "helplessness involves a syndrome of cognitive, emotlonal and motivational disturbances steming from repeated exposure to uncontrollable events." (Stokols, 1986, p.37). Julst het herhald blootstaan an dergellfke oncontroleerbare gebeurtenissen leidt ertoe dat individuen niet meer de kans zien datgene dat er feitelijk gebeurd te belnvioeden en danook hun pogingen daartoe opgeven. In dit kader past ook de theorie en het empirisch werk over de locus of control (Rotter, 1966). Het theoretiach potentiel en de practische toepasbaarhe id van dit soort concepten blifkt ult enkele nederlandse onderzoeken (Halfkens, 1985 en Hodiamont e.a., 1986). *7*

\subsubsection{De bijdrage van het netwerk}

In de vorige paragraaf gaf ik an dat er een relatie geconstateerd is tusien otress en life-events enerzijds en psychopathologie anderzijds. Fr blifkt ook wetenschappelifke belangsteling nar een moge$1 \mathrm{jk}$ samenhang tussen het soclale metwerk, in quantitatieve en qualitatieve zin, en het ontatan van psychopathologio.

De eerste (gepubliceerde) constateringen dat psychiatrische patidnten een kleine sociale kring hebben, blifken nlet zo oud (Post, 1962 geciteerd door Henderson e.a. 1981). Onderzoeken van o.a. Brown vestigden andacht op het felt dat bif vrouwen het hebben van een intieme relatie bescherming biedt tegen het ontstaan van een depresse (Brown \& Harris, 1978).

Deze onderzoeken gingen van een specifieke diagnostische categorie ult om daarmee de relatie tussen die stoornis en het netwerk te bezien. Laten if echter de beperking tot én diagnostische categorie los dan blifkt hetzelfde resultaat. Er blijkt en samenhang tussen het ingebed zifn in sociale verbintenissen en de anwezigheid van psycho-pathologie (0.a. Miller \& Ingham, 1976). 
Ontrent de richting van de causalitelt in deze samemhang ligt er en soortgelijk probleem is zoeven angegeven bil 11 fe-events.

\subsubsection{Hultifectorisie bevindingen}

Sinds een arntal jaren lijken het medisch en het soclaal model te zljn vermengd in een hernieuwde poging on de sprelding van psychiatrische andoenligen over de populatie te begrlypen en boclale factoren die een etiologische verklaringskracht hebben vat te atellen.

In het $z . g$. NIjmeegse regloproject heeft men mlddels een tree-fasen bevolkingsonderzoek op en als betrouwbar geachte wijze (Ming e.a., 1977; Duncan-Jones Henderson, 1978) de prevalentle van psychische stoornissen in de open populatie vastgesteld. Daarnaast heeft men o.a. de psycho-sociale problematiek, de copingstijl en het soclale netwerk per respondent bepaald (Hodfamont e.a., 1986). Ten anzien van interpretaties inzake mogelijke causalteltspatronen is de Nijmeegse groep zeer bescheiden, ondat een dwarsdoorsnede-onderzoek als in het onderhavige geval, dit soort pretenties niet kan warmaken.

Het onderzoek van Henderson en de zijnen in het Australsche Canberra (Henderson e.a., 1981) is lets ouder dan het zojulst besproken project. In Canberra heeft men een zelfde soort case-finding technlek gehonteerd; een twee-fasen design met enkele screeningsinstrumenten In de eerste fase en een diagnostisch instrument in de tweede fase. Dit onderzoek heeft zich sterk gericht op de soclale ongeving van de respondent en de invloed die hiervan uit zou gaan; met name het sociale netwerk krijgt volop aandacht. Bovendien wordt er in dit project een follow-up studie uitgevoerd bij een deel van de (ateekproef) populatie om zodoende het verloop van de stoornls (of het ontstaan van een stoornis) in zijn 'natural setting' te bezien. Henderson et al. concluderen voorzlchtig dat er aan de soclale ongeving mar weinig etiologische warde kan worden toegekend. Bepaalde persoonl1jkheldskenmerken daarentegen blijken een grote voorspallende warde te hebben t.a.v. de an-/afwezigheid van psychopathologle tijdens de follow-up. Ook de bevindingen van ormel (1980) wifzen in dezelfde richtimg. Hij stelt dat ondervonden gebeurtenissen niet rechtstreeks tot een psychische stoornis lelden, mar dat de persoonlijkheddsstructuur van het individu een significante factor blijkt.

Naar aanleiding van recente bevolkingsonderzoeken (zoals van Henderson, et a 1, 1981 en Hodlamont, e.a, 1986) kan het puntprevalentlecljfer van psychische stoornissen op ongeveer $10 \mathrm{z}$ geschat worden; het jaarprevalentiecljfer op 20 a 25 (Glel e.a., 1983).

\subsubsection{Transcultureel onderzoek}

Deze onderzoekstraditie is voortgekomen uit een samengan van psychiatrische concepten en de culturele antropologle. Onlangs is nog eens gewezen op het wat vreemde prefix "trans" (Favazza, 1986); men 
(anonlem, 1986) geeft daarop do opmerking dat binnen de transculturele psychlatrle een vergelijking wordt genalkt tussen de ene (meestal onze westerse) en een andere cultuur, warblj verschillen in etiologlsche factoren, mar vooral in de ongangsvomen met psychlatrische stoornisien geconstateerd worden. In de culturele psychlatrle darentegen wordt de relatie tusaen een specifleke cultur en psycho-pathologle $\star B *$ gezocht. De eerste moort studles benoemt men wel met de term "etic'; de tweede met "emic". Bezien wij de publicaties vanult dit onderzoeksveld (Favazza \&aheem, 1982) dan valt op dat hoevel belde soorten studies voorkomen, de meeste atudies toch als culturele psychlatrie zijn te beschouwen. In het verwijzen naar literatur e.d. zien we dat vaak een impliciete vergelijking met onze - Igen reaterse samenleving wordt gemakt.

Dat bif onderzoek (In onze elgen, maar ook in andere culturen) nogal ens vergeten wordt soclale en culturele factoren mee te nemen blijkt o.a. ult de International Study of Schlzofrenia, waarin wordt vastgesteld dat in niet-gelndustrialiseerde landen (met vergelijkbare incidentleciffers voor schizofrenie in gelndustrialiseerde en niet-geindustrlaliserde landen) de achizofrene episoden korter zijn (Sartorius e.al., 1978). Dit, terwijl een verklaring hiervan in sociaal en cultureel opzicht -hoewel gelndiceerd (Cooper \& Sartorius, 1977) en -1ders vastgesteld (Edgerton, 1980)- uitblijft en ook het netwerk ten onrechte geen andacht kr1Jgt $* 9 *$ (Beels, 1979; Cohen \& Sokolovsky, 1978).

Hier is echter de belangrijkste conclusie dat de incidentie-rates van ernstige vormen van psychische stoornissen in de $\mathbf{z} \cdot \mathbf{g}$. ontwikkelde en onderontwikkelde landen war geen ultgebreid professloneel GGZsysteem is, in dezelfde mate voorkomen. Vanult deze redenering heeft het geen $z$ in vol te houden dat de gezondheidszorg een gezondheidszorg-probleem achept; wel dat de gezondheldszorg bepaalde 'zijnswifzen" en sociale problemen als psychische -en in principe behandelbare- stoornisien definiert en daarmee ook mede bepaalt hoe met 'gekte" soclaal wordt ongesprongen.

\section{4. Samenvatting en conclusies}

In dit hoofdstuk heb $1 \mathrm{k}$ beargumenteerd dat in de psychiatrische epldemlologie onze culturele visle inzake bepalde vormen van afwlkend gedrag besloten ligt: hetzelfde geldt dus ook voor de definitle velke gedragingen tot deze bepalde vormen van afwijkend gedrag behoren en welke nlet. In onze culturele visie ligt eveneens besloten hoe in 'technische' zin -carling en curing-omgegaan dient te worden met dit afwijkend gedrag. Deze culturele visle wordt in sterke mate gevormd door de paradigmata zoals die kort besproken werden in 2.2.1. (de medische optiek on haar varianten) en in 2.2.2. (psychologische vorklaringen). Bovendien zijn deze theoretische opvattingen terug te vinden in (delen van) de GGz en blijken zif aanleiding tot een grote mate van differentiatie in de GGz als voorzie- 
ningen-pakket. Uit de macro-optilek zifn geen concrete gezondheldszorg-activiteiten, uitgezonderd de afdeling preventie van de Rfagg, naar voren gekomen. Wel zijn een antal overheidsmatregelen op macro-niveau in het kader van de psycho-hygiene te beoordelen.

Vast te stelien 1 dat 'gekte' niet en dermate eenduldig begrip is dat een enkele discipline de oplossing kan aanrelken. Wat betreft de definitie is in de loop van het afgelopen decennium een zekere consensus gegroeld. In de hedendagse psychiatrische epldemiologle komen concepten en methoden (en de darbovenstande methodologie) vanuit de verschiliende disciplines bijeen. Voor de psychlatrische epldemiologie ligt het vertrekpunt in de psychlatrie, in de daar geformuleerde opvatting inzake psychlatrische stoornissen. Het onderzoek binmen de psychlatrische epidemiologle is van groot belang, mar kent door zijn culturele inbedding een beperking, namelijk do veronachtzaming van het gegeven dat er een relatie bestaat tussen (sub)cultuur, socialisatie en matschappelijke positie an de ene kant en psychopathologie en omgang daarmee aan de andere kant.

Uit de bespreking van het transculturele onderzoek blijkt immera dat het noodzakelijk is de invloed van de (sub)cultuur mee te nemen; vooral de omgang met afwijkend gedrag blijkt sterk cultureel bepaald. Het is om die reden dat ik ervoor pleit de empirische bevindingen van de psychlatrische epidemiologle te herinterpreteren in een macrooptiek, warin gevraagd rordt nas de functie van de GGz als een sociaal subsysteem.

In deze bundel zal ik mij beperken tot een beschrifving van de GGZ als sociaal systeem. In de eerste plaats wordt beschreven uit welke voorzieningen de GGZ is opgebouwd en hoeveel patienten daarbij betrokken zijn. Hierbif tracht ik enig inzicht te geven in de mate van reglonale eigenheid van de GGZ.

Ten anzien van de "doelgroep' kan $1 k$ nu al stellen dat ongeveer een tiende van de nederlandse populatie (op één tijdstip) in anmerking komt als mogelijke gebruiker. En door het amtal paradigmata die nast elkaar bestaan, mogen we verwachten dat de GGz-consument te maken krijgt met een grate differentiatie in het zorganbod.

In de tweede plats stat in deze bundel de GGZ als organisatio centraal. Ik ben geinteresseerd in har functioneren en daarom vraag ik in hoeverre er een samenhang tussen de voorzleningen bestart, ma.w een vraag nar de mate van afsteming tussen de GGZ-voorzlenfingen onderling.

Tenslotte wil ik bekifken we feitelijk van de GGZ gebrulk makt. Uit de eerder gememoreerde bevindingen mag gesteld worden dat nlet ledereen eenzelfde kans op geestelijke gezondheid heeft. Ongeacht de etiologische verklaring moet verwacht worden dat en antal categorleên in de samenleving te kampen hebben met een slechtere geeste1ijke gezondheid, met name diegenen met een (te) klein soclaal netwerk en/of met een stressvolle gebeurtenis achter de rug. Een van de vragen die beantwoord dienen te worden, is of deze categoriekn ook in de GGZ oververtegenwoordigd zijn. 
HOOFDSTUK 3

\section{IMTERARZZO: HET HIKNSELIJK HANDEIKN}

\subsection{Inlelding}

Dit hoofdstuk zal de lezer in directe zin maar weinlg over de GGZ leren. Wel worden hier vanuit de handelingstheorle bouwstenen aangedragen warmee ik in de komende hoofdstukken verder kan werken. Hede vanuit de in het vorig hoofdstuk angedragen 1 deesi wil ik in dit hoofdstuk de stelling verdedigen, dat de mens voor alles een 'cultuurlijk' wezen is (Lemalre, 1976). Hij percipleert en gat om met de wereld zoals hem dat door middel van zifn socialisatie - in de brede zin enculturatie en acculturatie- mogelijk is geworden ${ }^{*}$. Vanult die optiek zal $1 k$ vooreerst het menselifk handelen als zingevende activiteit theoretisch plaatsen, warbij de context warin dat handelen geschiedt van belang blijkt.

\subsection{Het sociaal handelen als zingeving}

Cultuur $\star 2 \star$ kan worden opgevat als een stelsel van warden en normen, die per samenleving anders geformuleerd en samengesteld zijn; ook binnen een samenleving - per subcultuur- zijn er variaties mogelifk. In cultuur $1 \mathrm{fgt}$ het leidend principe besloten volgens welke individuen handelen en dit handelen zin krifgt. De betekenis van het soclaal handelen is cultureel verankerd en, julst omdat personen in een samenleving een min of meer gelifk cultureel patroon in het hoofd hebben, handelen individuen meestal zo als de ander dat verwacht. Tijdens het handelen maken individuen een keuze ult vele mogelijke handel ingen.

\subsubsection{Interactie als complexiteitsreductie}

Cultuur helpt het individu de hem omringende chaos te structureren te ordenen wardoor hif de complexiteit van de wereld kan reduceren. Tegelifkertijd geeft cultur richting an het sociaal handelen: de (sub)cultur reikt het individu interpretatiekaders an op grond warvan het individu $21 j n$ omgeving warneemt, vormt on wardoor sociaal handelen pas mogelifk kan worden.

Voor Luhmann (1975) is het kleinst denkbare soclal grtem het Interactiesysteem. Dit bestaat uit de handelingen van twee interacterende actores. Een dergelijk systeem zou slechts kunnen bestaan, Indien an de volgende voorwaarden voldaan is: 1 ) de anwezigheld van personen; 2) wederzijdse warneming van de aanwezigen, wardoor een diffuse structurering ontstat on 3) er een selectieproces volgt bijvoorbeeld door middel van verbale communicatie. 
De functie van en interactiesysteem is reductie van complexiteit. Het madee 1 van Luhmann's opvat ing 18 , dat handelen buiten een interactiesysteem alet la sociaal handelen begrepen kan worden.

\subsubsection{Typen goclaal handelen}

Onlangs 1 s door Peters (1986) beargumenteerd, dat er ten gevolge van en verkeerde interpretatie van het verk van Weber -en in die wetemschapstradtie bevindt Luhwann zlch ten dele- belangrijke aspecten van het menselijk gedrag niet als sociaal handelen zijn aangemerkt. Deze interpretatle zou ontstaan zijn omdat er te weinig andacht is geschonken an het begrip 'sociale relatie' zoals Weber dat hanteert. Hif onderacheidt namelifk twee vormen van sociaal handelen: "1) het soclaal handelen $1 \mathrm{~g}$ soclale interactie twee personen orienteren hun handelen qua zingeving wederzijds an het verloop van dat handelen en 2) het social handelen dat an de "zinfnhoud" van een sociale relatie is georlenteerd" (Peters, 1986, p.9). Daarbij wordt sociaal handelen van handelen onderscheiden door het criterium betrokkenheid op de ander.

Er is sprake van een kans -'Chance' bij Weber-dat er op een bepalde wijze soctaal gehandeld wordt; een actor kan bepaald sociaal handelen van de ander verwachten door de zingeving die aan het sociaal handelen ciq. de soclale relatie gegeven is. Deze zingeving wordt echter objectief eenzlj $\mathrm{dg}$ gedacht $* 3 *$. Het soclat handelen kan dus bepald niet deterministisch opgevat worden.

Vanult beide optles -van Luhmann em van Weber-formuleer ik het sociaal handelen als volgt: sociaal handelen orvat al die menselijke gedraglngen die gekenmerkt worden door een aubjectieve (of objectief eenzljdige) zin(geving) en die verbonden zijn aan een directe handeling dan wel aan een (beoogde, bedoelde of feitelijke) relatie met een ander lndividu $* 4 *$. De functie van het sociaal handelen is reductie van complexiteit.

Daarme is bifvoorbeeld het schrijven van dit hoofdstuk in mijn entje achter mijn bureau op te vatton als een sociale handeling, omdat het schrifven gedridnteerd is a an andere actores: bovendien wordt tijdens dit proces complexitelt gereduceerd door uit alle mogelifke onderwerpen juist deze te kiezen en deze langs een specifleke invalihoek te beschrijven.

Mensen handelen nlet vanuit een nulsituatie; niet alles is nieuw, neutraal. Een mens brengt zichzelf tifdens het sociaal handelen in en bepalt mede zodoende zijn elgen zingeving van het social handelen. Ondank de elgen Inbreng gedragen mensen zich meestal voorspelbaar; zif geven een elgen zingeving a an hun handelen dat de ander kan involien. Om dit te begrifpen ('zu verstehen") gebrulkte Weber de term 'Elnstellung': hlervoor in de plats gebruik fk nu, in navolging van velen, de term attitude. Aan dit begrip zijn vier componenten te onderschelden: 1) een fysieke; 2) een cognitieve; 3) een affectieve en 4) en evaluatieve component. 
Het name de drie latste componenten komen wif in cultuurbenaderingen tegen onder de begrippen kennis, motivatie en normen. Het zijn julst deze attitude-componenten die tifdens de soclalisatie door een Ind1- Idu vorden angeleerd. In dis zin is een mens een soclaal en cultureel dier, warbij de angeboren constitutle, ard e.d. weliswaar randvoorwarden angeven, mar slechts ten dele voor de anwezige variatie in het sociaal handelen verantwoordelijk Beacht kunnen worden.

Enerzijds wordt een attitude relatief constant gedacht, wardoor deze als een relatief constante orlunterings-en gedragspredispositie kan werken. Daarmee vornt deze predispositie een voorwarde voor continulteit en consistentie in het gedrag onder isselende omstandigheden. Anderzijds zullen attitudes over langere perioden kunnen veranderen juist ten gevolge van (aanhoudend) veranderde omstandigheden, wardoor een indiuldu door middel van leerprocessen tot ander sociaal handelen kan komen.

De relatie tussen cultuur en het soclaal handelen komt met behulp van de attitudes tot stand. Vanuit het sociaal handelen is een social leven -een sociaal systeem- denkbaar als een relatief stabiel, mar ook een $z$ ich veranderend geheel.

\subsubsection{Continulteit en verandering}

Ondanks dat er telkens nieuwe generaties verschijnen, kent de samenleving een grote mate an continulteit. Uiteraard is de feitelijke blologische reproductie van nieuwe generaties met een min of meer gelijk biologisch apparaat een eerste vereiste voor die continulteit. De stap van de mens als natuur 1 ijk mar de mens als cultuurlifk wezen 1s groot: deze stap is echter in een menselifke samenleving noodzakelifk. Dit heeft consequenties voor de wijze van informatieoverdracht van de ene nar de volgende generatie. Socialisatie is in wezen niets anders dan het overdragen van informatie; $z$ ij het dat het medium niet genetisch van aard is. Daardoor blifken socilale veranderingen sneller te kunnen verlopen dan biologische. Over korte perioden zijn al grote veranderingen warneembar.

Om te kunnen verklaren welke mogelijke veranderingen ook daadwerkelijk voet aan de grond krijgen, plaatst Luhmann de mogelijkheid tot verandering central. Luhmann hanteert het begrip 'communicatief succes' als sociaal selectiemechanisme warmee een soclaal system wardevolle (functioneel in een specifieke constellatie) oplosingen bewart. Mede door het hoge abstractieniveau van Luhmann's systeemtheorle is deze benadering tamelijk inhoudsloos: $d, w . z$, de theorle kan as een schema gehanteerd worden, mar dient nader geconcretiseerd te worden met betrekking tot het onderwerp warnar de interesse uitgaat. Hondrich (1975) stelt bifwoorbeeld voor Luhmann's schema in te vullen m.b.v. een behoeftetheorle. 


\subsubsection{Frictiog In het soclaal handelen}

In deze paragraaf gat mijn interesse uit naar situaties warin het social handelen mislukt. Hanneer zijn er fricties in het soclaal handelen te constateren? Wanneer wordt er afgeweken van de 'Chance' In het soclaal handelen en hoe zljn deze vormen van soclaal handelen te typeren?

De af $1 \mathrm{jkingen}$ in het verwachte social handelen kunnen worden benoemd a het optreden van wederzllds incompatibele zingevingen. Deze Incompatibilitelt is toe te schrijven an een tegenstelling tussen de attltudegystemen van twee actores $\star 5 \star$. Die tegenstelling kan op onderdelen -cognitlef, evaluatief of affectief-van de attitudes betrekking hebben en nar aanleiding daarvan is een deel van het soclale leven geinstitutionaliseerd (van gevangenis tot Blijf-vanmiln-LIf huizen, van hulsarts tot psychiatrische ziekenhuizen).

slechts en deel van alle afwijkingen in het sociaal handelen zijn relewant met betrekking tot het onderwerp 'gekte'. Dit deel van het afulkend sociaal handelen is niet anders te begrijpen dan andere vormen van afwijkend sociaal handelen. 'Gekte", psychische stoornis, definleer ik als een nlet-individugebonden onvermogen om dusdanige sociale handelingen te laten platsvinden dat aan de directe interactie of an de (beoogde, bedoelde of feltelijke) sociale relatie wederzifds zin gegeven wordt. In feite vindt er tijdens die vormen van social handelen geen of onvoldoende complexiteitsreductie plats.

Afwjkend sociagl handelen komt tot uiting in het sociaal handelen en het komt voort uit een combinatie van persoonsgebonden "maar in het sociale leven ontstane, attitudes gegroeid op en biologisch substrat en de reacties hierop door andere voor de persoon relevante actores. Het sociale systeem als totaliteit, gebaseerd op en mogelijk gemakk door de complexiteitsreductie tijdens het sociaal handelen, wordt in principe bedreigd, indien er in de interactiesystemen onvoldoende complexiteitsreductie platsvindt *6*.

\subsection{Zlngeving en context}

Complexiteitgreductie is voor ieder sociaal systeem en dwingend gegeven. Het ageme van onze samenleving is dat steeds meer zaken uit de ongeving geproblematiseerd worden. Onze samenleving is steeds sterker gedifferentlerd geworden, wardoor er een grotere complexiteit in de amenleving is ontstan. Hierdoor kunnen steeds grotere prestaties wat betreft complexiteitsreductie plaatsvinden. Dat wil zeggen dat de omringende chaos minder als chaos, als drelgende naturi of door God gegevon beschouwd vordt. Ten gevalge van arbeidsverde$1 \mathrm{lng}$, peciallsatie en kennisopslag/overdracht is het mogelijk in de tijd groter wordende delen van de omgeving beheersbar, planbaar, invoegbar te maken. 


\subsubsection{Civiliatie en peychiache beleving}

Weber (1972) spreekt in dit verband over de 'Entzauberung der Welt': met deze term bedoelt hif een proces warin de samenleving en ons sociaal handelen steeds meer van rationalitelt doortrokken rakt. Ellas (1984) daarentegen benadrukt dat niet rationalitelt mar vooruitzien ons gedrag steeds meer kenmerkt. Dit voorultzlen is in zijn optiek (zle ook de Swean, 1984) steeds sterker tot gedragsdispositie geworden. Voorultzien is een onderdeel van onze attitudes geworden.

Ellas laat zien dat het vooruitzien ten gevolge van de langer wordende afhankelijkheidsketens noodzakelifk werd *7*. Aldoende beargumenteren Elias en de Swaan dat de psyche van het individu in de loop der tijd steeds meer taken naar zich toe geschoven krijgt. Daarbij hoort een overgang van 'Fremdzwang' nar 'Selbstzwang': het Individu internaliseert nu veel van wat vroeger van buiten kwam en gelegitimeerd werd.

Dit verdergaand internaliseren is noodzakelifk omdat het sociaal handelen in die lange afhankelijkheidsketens in sterke mate voorspe1baar dient te zijn. Dwang van buitenaf kan dit niet bewerkstel1igen; 'Selbstzwang' is een veel effectiever middel. Elias laat zien dat het clvilisatieproces over een lange periode optreedt en dat de 'Selbstzwang" steeds meer op de voorgrond treedt. Dok over kortere perioden is een dergelifke -ulteraard relatieve- overgang van "Fremdzwang" naar 'Selbstzwang' te signaleren (Kapteijn, 1985).

Hoewel er winst van het civilisatieproces te constateren is, moet geconcludeerd worden dat het leidend cultuurbeginsel - In mijn opinie te benoemen als instrumenteel ratlonalisme $* 8 *$ (Lemaire, 1976)- voor het individu ook negatieve consequenties heeft.

\subsubsection{De ataat als verzorger}

In het civilisatieproces wordt an de stat een sleutelpositie toegedacht. Als een belichaming van "le contract social" is de stat gelegltimeerd, onder verwijzing nar en situatie warin een ieder in oorlog met de ander verkeert, het regelend principe te worden. Hierdoor worden vergaande vormen ven arbeldsverdeling en speciallatele mogelijk. Er ontatan lange afhankelijkheldsketens warin velen van velen, telkens voor andere facetten in het leven, afhankelijk $21 j n$. De staat is dariblj zelf geen verzorger, zij is geen peraoon (de Swaan, 1984), mar zif makk het anderen mogelifk to verzorgen, te onderwijzen, te verplegen, emancipatieprocessen op gang te brengen, etc. Voor deze regulering heeft de stat een budget nodig. Dat daarbif dit budget een steeds groter deel van het national inkomen uitmakt, is noodzakelifk om ten gevolge van de arbeidsverdeling steeds meer middelen te realloceren. Dit wordt momenteel als een economisch probleem gezien wartegen een monetair gebrienteerde politiek in stelling wordt gebracht. Echter, hier lifkt sprake van een probleemverschuiving warblj het wezenlijk probleem verdoezeld wordt.

Het eigenlijke probleer bestaat daarin, dat en steeds groter wordend 
deel van het prive beataan van het individu publiek wordt. Zijn wij onze samenleving gestart onder het principe van Hobbes om onszelf te vrljwaren wan (levensbedrelgende) misdragingen van onze medemensen, dan ordt dit principe nu gehanteerd tegen een gemeenschappelijke vijand ( $b . v$. kans op ziekte) en daarin komt onze specifieke vorm van solidarltelt naar voren. De situatie in onze samenleving kan met een citat van Koot stegerhok als volgt omschreven worden: "De mate van (H.H.; beataans-) zekerheid voor allen is gebaseerd op alldarlte1t." (Koot stegerhoek, 1986, p. 53). Dit houdt in, dat er In zekere mate sprake moet $21 j \mathrm{n}$ van een redelijke, rechtvaardige verdeling van de sociale goederen: "In de context van de verzorglngstat (warbij de zorgzame samenleving als een amendement darop gezien wordt; H.H.) is samengestelde gelijkheld de concrete Invulling geworden van het ideal van en rechtvaardige samenleving." (Koot \& Stegerhoek, 1986, p. 54). Deze samengestelde gelijkheld wordt op verschillende manieren bewerkstelligd, warbij centraal staat, dat Individuen die in relatief opzicht aan een sociaal goed gebrek hebben datroor becompenseerd worden. Echter, telkens wanneer een lindividu 'gecompenseerd wordt' wordt een deel van de persoonlijke leefwereld door het publleke gekoloniseerd (Habermas, 1982).

\subsubsection{Optimallsering en proto-professionalisering}

Ieder mens heeft de fundamentele behoefte zich als mens te verwezenlifken: een mens is niet, maar wordt (Maslow, 1968). De wijze warop deze verwezenlifking gestalte krijgt, is cultureel bepaald. De hidrarchle in de behoeftenboom zoals Maslow die opgesteld heeft, 1ijkt een universele geldighefd te hebben. Echter, tot op welke hoogte de hierarchle ingevuld wordt, is cultureel bepaald. Dit geldt ook voor de vorm dle bif deze lnvulilng gekozen wordt. Het is in die zin dat behoefte per definitie culturel gestalte krijgt en er vervolgens behoefte ontstat an voorzieningen, zorg, 1.h.a. an instituties warin het culturele als sociale verdichting vorm krijgt. Instituties op hun beurt hebben als sociaal subsysteem hun eigen dymamiek en beinvloeden de vigerende cultuur; zij veranderen deze, brengen ultbreidingen aan, claimen delen van het leven, kortom zij belnvioeden opvattingen omtrent menselijke 'zijnswijzen', verklaringen daaromtrent en formuleren vanult die verklaringen problemen, warvoor nu nieuwe oplossingen denkbaar zijn.

De ultuindingen als nleuwe culturelementen kunnen langs verschillende vegen onder de populatie verspreid worden. Vanult de gezondheldszorg gebeurt dat op twee manieren. Enerzijds direct: namelijk wanneer individuen in aanraking komen met die sociale subsystemen die als exponent $v a n$ dat culturelement fungeren. Anderzijds indirect: en dat gobeurt dan via de media, via contact met professionals en semi-professionala (Oosterbaan \& Zeldenrust, 1985). 
Optimalisering van leders persoonlijk leven en proto-professionalisering horen bif elkar. Wanneer nleuwe cultuurelementen oplossingen $11 \mathrm{jken}$ te bleden voor tot nu toe onbevredigend opgeloste problemen en mensen krijgen er lucht van dat zodoende oude problemen geherformuleerd, opgelost en/of verzacht kunmen worden, dan zal de protoprofessionalisering zlch uitbrelden en de behoefte toenemen.

In de volgende paragraaf zal ik een laatste reden geven, warom de behoefte an diverse instituties in de $t$ ijd is toegenomen.

\subsubsection{Stigmatiserfigg en pijniljkheid}

Wij zijn het ls ateeds pijnlijker gan ervaren met elgen en met andermans ellende, leed, afwijking, intimitelt geconfronteerd te worden. Daaraan parallel loopt het proces van individualisering met als tegenhanger de ervaren pijnlijkheid, de gevoelens van gêne die in de loop der tijd sneller optreden. De 'Selbstzwang' is met name hieromheen georganiseerd.

Er zijn nog andere gevolgen van het clvilisatieproces an te wijzen. Wif handelen met zovelen voor wat betreft slechts gefragmenteerde aspecten van het leven, zodat onze gedragingen affectneutraler zijn geworden. Dat houdt in dat er in het algemeen geaccepteerde soclaal handelen meer varlaties ontstaan zijn; hierdoor kon aanvankelijk deviant gedrag -hoewel het een minderheidsgedrag blifft-geaccepteerd worden, zif het met wisselend succes, maar de trend is duldelijk. Als wij tegenwoordig lemands gedrag in e6n rol -b.v. de sexuele- niet accepteren, 11 dat nog niet zeggen dat wij hem in andere rollen niet handelingsbekwaam zouden achten en juist het totale afwijzen heeft met stigma te maken. Wij accepteren in steeds sterkere mate variaties in het gedrag en wijzen minder mensen af, ondanks dat zij gedragingen vertonen die wif vanult onze elgen 'gêne-drempel" voor onszelf niet accepte vinden; het toppunt van zelfdwang.

Voorlopig concluderend zijn enkele, op het eerste gezicht tegengestelde bewegingen, te onderkennen: 1) een toenemende tolerantie voor andersoortig gedrag en een darmee samenhangende vermindering van matschappelijke stigmatisering in de vorm van ultstoting; 2) een vergroting van de gevoeligheld voor allerhande zaken die in het leven zoal mis (kunnen) gaan en 3 ) de ontwikkeling van technteken (en van instituties war deze gepractiseerd worden) on deze problemen alsnog op te lossen te herdefinieren *9*. Totale uitstoting als verschijnsel treedt steeds minder op: echter, een groter antal personen dan oolt wordt op enigerlel wifze met een partiele uitstoting geconfronteerd.

\subsection{Samenvatting en conclusies}

Twee belangrijke opties kwamen in dit hoofdstuk an de orde. De eerste optie is dat psychische stoornis gelinterpreteerd kan worden in termen van (mislukte) sociale handelingen met daarbij de link naar 
cultuur als het vooratructurerend lement. Vanult deze stelingname kunnen botsingen en mlolukkingen in het social handelen Beinterpreteerd vorden. Uitgande van de algemeen abvarde cultureel gedefinigerde verkelijkheid vordt een van de individuen $* 10 *$ als patlent, alo crlmineel of al deviant gebrandmerkt. Tegelifkertijd is op theoret sche gronden plauslbel geraakt dat ij in toenemende mate gevoellg zijn voor elgen en andermans fellen en er darrom een toenemende behoefte zal z1jn dt fellen ongedaan te maken.

De tweede opt le $1 \mathrm{lg}$ op macro-nivo en komt voort uit de vaststelling dat ons soort samenleving gebouwd is op basis van onderlinge afhanke11jkheid. Julst daarin kan ten gevolge van arbeldsverdeling, speclallsatle, d. het instrumenteel rationalisme als leidend cultur princlpe steeds aterker mar voren komen. Het tweespan onderlinge athanke11jkheid en instrumenteel rationalisme geeft aanleiding tot een situatie warin wij trachten tot een redelijke verdeling van alerhande soclale goederen te komen. Gezien de technische, economiache, mediche en educatieve ontwlkkelingen blifkt deze redelijke verdeling realiseerbar. Toch wil dit alles niet zeggen dat de bestaande ociale ongelijkheid opgeheven zou zijn. Echter, de verpakking in de vorm van samengestelde gelijkheid oogt humaner. Als negatlef bijeffect heb ik gewezen op het koloniseren van het prive-bestan door het publieke zoals dat vorm gegeven is in en gepractiseerd wordt door diverse instituties. Deze instituties $z i j n$ te bezien als soclale verdichtingen van culturele subsystemen. De GGZ kan als een dergelijke sociale verdichting beschouwd worden.

Concluderend kan gesteld worden, dat sociale ongelifkheid naar voren komt als onderzocht wordt welke categoriezn in sterkere mate dan anderen gecompenseerd worden met als optie te mogen deel hebben in onze samengestelde gelijkheid.

Tot slot ijs ik erop dat door middel van het instrumenteel rationa1 isme meer complexiteit gereduceerd kan worden. Wij kunnen nu vraagatukken en problemen aanpakken en tot oplossing brengen door gebrulk to maken van methoden, technleken en denkwijzen zoals die in de (po- itivistische) wetenschapsbeoefening ontwikkeld aijn. Wij kunnen deze zodanls toepassen dat het te bewerken "materiaal" het probleem, tijdens een proces verandert in een gewenst 'elndprodukt". Om dit klar te apelen aljn wij in steeds aterkere mate van anderen afhankelljk (en zij van ons) en dient er t1jdens het sociaal handelen ateeds gedisciplineerder met elkar omgegaan te worden. Wat betreft dit latste is te concluderen dat het noodzakelijk is per individu meer informatie c.q. meer gedragsregels beschikbaar te hebben. In die zin legt de matschappelijke "wens" steeds meer complexiteit te reduceren en grote druk op het individu. 
HOOFDSTUK 4

DE GERSTKLIJKR GEZONDHEIDSZORG ALS HAATSCHAPPELIJK FENOWEWN

\subsection{Inle 1ding}

In dit hoofdstuk zal het ontstaan van de GGz kort besproken worden: en van daaruit zal ik de huidige GGz beschrijven. Daarblj zal $1 \mathrm{k}$ kort andacht besteden an de doelen van de GGZ en de lyze warap men deze denkt te bereiken.

In de daarop volgende paragraaf, 'de GGZ als collectleve zingever?', zal ik een link leggen tussen de theoriefragmenten zoals die in het vorig hoofdstuk verwoord zijn en de implicaties daarvan deduceren.

Alvorens tot enkele afsluitende conclusies te komen, zal ik enkele lijnen uitstippelen warlangs de huidige GGz verder zou kunnen evolueren.

De centrale stelling die hier verdedigd zal worden, is dat de GGz in deze samenleving onze vorm is om met 'Bekken' om te gaan en dat die vorm in sterke mate historlsch en cultureel bepald is. Echter -en dat is de contradictionaire situatie warin de GGZ zich bevindt- de GGZ kan principielel niet anders met har clientele omgan dan cultureel voorgegeven is. zij heeft daarbij bovendien rekening te houden met een verplichting tot het afleggen van verantwoording an de hand van cultureel vastgelegde criteria. Dus de GGZ dient zich war te maken in rationele en utilitaire zin; vandaar de belangstelling voor evaluatie- (b.v. Beenackers, 1986) en effectonderzoek (b.v. Schagen, 1983 en $1985 * 1 *$ ).

Mijn belangstelling gat uit nar de betekenis en de functie van de GGz in onze sameleving. Om deze belangstelling vorm te geven moeten twee aspecten onderscheiden worden. In de eerste plasts wat is de bijdrage van de GGZ aan onze samenleving, wat hebben wij er als maatschappij aan? In de tweede plats zal $1 \mathrm{k}$ beargumenteren dat de GGZ vorm heeft gekregen in onze samenleving en darmee als het ware doordrenkt 1s. Beide aspecten kunnen met behulp van het begrip context benaderd worden: de GGZ zoals die nu zichtbaar is -en die zichtbarheid zal $1 \mathrm{k}$ in de latere hoofdstukken empirisch onderbouwen$1 \mathrm{~s}$ in sterke mate bepald door onze (specifleke) samenleving en het krachtenspel daarin. De GGZ moet gedacht worden in een context die enerzijds uit andere soclale subsystemen (de overheld, het 'beleid', financieringsmoge $11 j k h e d e n, e . d$.$) bestaat, mar die anderzijds door$ haar potenti\&le clientele gevormd wordt. Mar de GGZ op haar beurt vormt ook een context; namelijk voor de GGZ-patiênt (als gocial en cultureel ysteem) en voor leder individu als potentiele patient (als culturee1 aystem). 
Een latste Inleldende opmerking betreft de uitbreiding van de taken vanult de ambodzijde. Zoals onlangs Beckers (1986) veer eens in herlmnering bracht rorden er -ook in de GGZ- dingen ultgevonden die In feite nlet blijken te werken voor diegenen warvoor ze bedoeld - aren. Anderen blijken echter voor deze "uitvindingen" zeer gevoelig. Een behoefte pordt geboren en de doelstelling van een organisatie vordt verschoven ten gevolge van de nieuw aangeboorde of an te boren markt: de GGZ breidt het terrein warop zij betrekking heeft -gekte, afwifkend gedrag- utt. Zowel in de GGZ als in de samenleving zal dus In de loop der tijd een ultbrelding te zien zijn van verschijnselen de men doof mlddel van GGZ-technieken behandelbaar zal beschouwen; poradisch zal het terrein ingekrompen worden.

\subsection{De (GGZ) geschiedenis in vogelvlucht}

Wi1 de huidige GGZ als matschappelifk fenomeen beschreven worden, inklusief enkele contouren van de toekornsige GGZ, dan zal kennis omtrent hat voorganger(s) anwezig moeten zijn. Gelukkig heeft de geschiedenis van psychische stoornis en de omgang darmee de latste faren wetenschappelijke aandacht gekregen. Voor de volgende paragrafen kon lk dan ook gebrulk maken van een aantal studles, zoals die van Foucault (1965), Binnenveld e.a. (1982), Brinkgreve e. . (1979), Brinkgeve (1984), de swaan (1979), Bulhof (1983) en zeer recent v.d.Grinten $(1987)$.

\subsubsection{Omgangsvormen in vroeger tijden}

In de middeleeuwen werden psychiatrische patienten nauwelijks uitgestoten; wellswar waren zij vaak onderwerp van spot, maar zlj werden toch-soms op afstand (in het dorpje Geel o.a.)-door de familie verzorgd. Patienten die op drift, op zwerftocht waren gerakt, werden wel ult de door hen bezochte gemeenschappen gestoten.

De start van de grote opsluiting wordt door Foucault in de klassieke per1ode (1600-1800) bij het ontstan van de huldige statsvorm gedacht, mar door Peeters (in Blninenveld e.a., 1982) later geplaatst warbif hil stelt dat de opsluting in de klassieke perlode slechts marglnal is in vergelijking met die vanaf de tweede helft van de vorlgo eauw. In de klassieke perfode is er sprake van een ongedifferentluerde opslulting warvan zowe 1 psychiatrische patienten alsook anderszins losgeslagenen het slachtoffer werden, of zo wilt, konden profiteren. Het inrichten van grote gestichten -vañaf de tweede helft in de 19 e euw- zou men kunnen a anmerken als een, ruimtel1Jk nog steeds herkenbaar, beglnpunt van de huldige GGZ.

\subsubsection{Het pri11e begin}

Al: de tijd er rijp voor is; ofwel dezelfde ultvindingen worden zonder wederzijdse voorkennis door verschillende mensen gelijktijdig gedaan. 
In dat licht kunnen (sociale) uitvindingen, dus ook medische en psychiatrische uitvindingen, bezlen worden. Maar dan is de vrag ufterard, wat dat dan is als de tifd er rijp voor is peeters (Binnenveld e.a., 1982) noemt de extra-, inter-en intra-discursieve determinanten welke een rol spelen. Het ulteenrafelen hiervan lijkt mif een nuttige (monnikken)arbeid die buiten dit kader valt. Belangrijker 1 ijkt mij de constatering dat boortgelijke ontwikelingen voor diverse sectoren in de samenleving -zols het onderwijs en de algemene gezondheldszorg- vooral vanaf midden $19 \mathrm{e}$ eeuw geconstateerd kunnen worden.

In die periode ontstat het onderwifssysteem, het welzijnswerk en de gezondheldszorg in een vorm zoals die nog altijd herkenbaar is: met andere woorden er ontstaat een steeds sterker gedifferentielerde, gesegmenteerde, goeddeels verzullde samenleving als tussenvorm vanult de burgerlijke kapitalistische samenleving naar onze huidige postindustrièle samenleving. Een belangrijk kenmerk hlerbij is dat de arbefdsverdeling zich in een veel sneller tempo dan daarvoor voltrekt en juist in die tijd de afhankelifksketens (de Swaan, 1984) in zeer korte tijd groter worden. Het is dan ook de tijd warin nieuwe beroepen ontstaan en deze beroepen $z i c h$ met succes mengen in de strijd om erkenning, macht, etc. (Brinkgreve, 1984; Bulhof, 1983). Immers, die nieuwe beroepen kunnen aangeven dat zij noodzakelifk zijn in deze nieuwe samenlevingsvorm.

Vanaf dat moment kon de 'emancipatie' van opeenvolgende bevolkingsgroepen beginnen: en proces dat tot op vandaag aanwezig is. Maar voordat men mij misverstaat: de wezenlijke grondslag van deze emancipatie is, dat steeds grotere groepen in de samenleving passen en hieraan een (productieve) bijdrage leveren. Deze emancipatieprocessen moeten dan ook wezenlijk bezien worden als een verdere uitbreiding van het instrumenteel rationalisme als leidend cultuurprincipe. In dat licht kan ook de differentiatie in het hulpaanbad vanuit de GGZ bezien worden.

4.2.3. Het ontstaan van differentiatiea in het hulpaanbod

BIf de vroege voorlopers van de GGZ was slechts een zeer klein deel van alle psychisch zieken "In behandeling". Querido stelt dat tot ver in de $19 \mathrm{e}$ eeuw (Blobal de eerste helft) "het lot van geinterneerden zeer droef" was echter warschijnlijk was "het antal geinterneirden slechts een klein deel van alle geesteszieken ult die tijd." (Querido geciteerd door Romme, 1984)

Bovendien was deze categorle op dat moment nog nauwelijks object voor de medische retenschap: in de z.g. dolhuizen was cen mengeling te vinden van geesteszieken, zwakzinnigen en criminelen. Pas na de krankzinnigenwet in 1841 kon er lets gaan veranderen an het lot der geesteszieken. De verantwoordelijkheid kwam nu bif de provincie te ifgeen, terwijl ook In die tijd de psychiatrie zich manifesteerde als een medische professie. In deze tifd ontstaan de eerste psychiatrische ziekenhuizen, in de duinen, op de Veluwe en dicht tegen de 
landsgrenzen, telkens op afstand van bevolkingagglomeraties.

De oudste vorm van semimurale zorg is te zien in de z.g. gezinsverpleging, de voor een deel vanult het psychlatrisch ziekenhuis opgezet verd (in Wederland), maar b.v. in Belgie (Geel) van nog ouder datum 1s. Deze zorgvorm bestaat in deze vorm nog maar nauwelifks.

De ambulante zorg is als mazorg na ontslag vanult het psychiatrische zekenhul ontstaan. Deze vorn van zorg heeft zich vanaf de twintiger Jaren definitief in de rlJ van de voorzleninges geschard zoals: de soclaal psychiatrische dlenst (SPD in 1928), de ambulante zorg voor de zwakzinnigen (SEeD in 1923), het medisch opvoedkundig bureau (MOB in 1928), de Jeugdpsychlatriache dienst (JPD in 1931) en als laatste in deze serfe het Bureau voor Levens- en Gezinsmoeilijkheden (1935). Het consultatiebureau voor alkohol en drugs (CAD In 1945), het instituut voor multidlsciplinalre psychotherapie (IMP in 1940 gestart in de eerste bezettingadagen) zijn al van later datum, terijl het jonBeren advies centrum (JAC in 1970) de rif sluit. Vrifwel alle ambulante zorgsoorten zijn begonnen vanult een charitatieve achtergrond, warbij het particuliere 1 intlatief van groot belang was. De verzuilde vooroorlogse samenleving heeft ertoe bijgedragen dat deze zorg zich over de hele linle relatief snel uitbreldde (zie v.d. Grinten, 1987). Deze 11jn heeft zich na de tweede vereldoorlog voortgezet; het duurde lang eer de overheld $z$ lcht op de ontstane lappendeken kreeg.

\subsection{De huidige GGZ}

In de volgende paragrafen zal ik de huldige GGZ bespreken, waarbij doelen en functies an de orde komen. Vervolgens worden de GGZ-voorzleningen in hun onderlinge samenhang (en gebrek daaraan) beschreven.

\subsubsection{Beoogde doelen en functies}

Vergelifken wif de huldige GGZ met die van vroeger en met die in andere westerse landen dan blijkt dat het aanbod aan voorzieningen rijk en divers is. Naast behandelingsmogelijkheden zoals die echelonsgewijs opgebouwd zijn, kent de GGZ specifieke functies; functies soms in een (deel van een) voorziening gelocaliseerd, soms gelocallseerd in meer voorzieningen warbij er al dan niet sprake is van enlge samenwerking.

De algemene GGZ-doelstelling zou ald volgt geformuleerd kunnen worden: het verbeteren van de positie van de psychiatrische patient. Hoewel hiermee ledereen (In en bulten de GGz) het eens zal zijn, is de formulering te algemeen en ontstaan er tegenstellingen tussen de diverse GGZ-geledingen Indien de definitie geconcretiseerd wordt. Het 11jkt er sterk op, dat de GGZ zich de afgelopen decennia niet zozeer heeft bezig gehouden met het formuleren van de concrete doelen die zif als Institutie dient na te streven. Wel heeft men aldoende functies gereallseerd warmee (niet-geexpliciteerde) doelen bereikt zouden kunnen worden. 
De functies die de GGZ ls geheel biedt zijn de volgende: preventie (inkluslef vroegtijdige onderkenning), behandeling (inklusief de opvang van acute crises), verzorging en (re)sociallsatie (zle ook Romme, 1985). Daarnast - als ondersteuning om deze functiea blifvend. war te maken- houdt men zich bezig met evaluatie en planning en schenkt men andacht an diverse cholingsmogelijkheden voor de werkers.

Echter niet alleen deze functies bepalen de structuur in de GGz. Deze is Immers ook opgebouwd naar (potentible) patidntkenmerken o.a. naar leeftijd en de meest naar voren komende problematiek (zie ook Romme, 1984). Zo kent men binnen de GGZ aparte circuits nar leeftijd (voor jongeren, voor de volwassenen en voor de bejamide populatie), naar problematiek (b.v. alcoholcircuit -zie ten Horn, 1976). Ook binnen instellingen wardt nader naar soort behandeling gedifferentierd.

Als wij de GGZ bezien, dan is te constateren dat en breed takenpakket anwezig is, terwifl de grens tussen de GGZ en andere instituties en de grenzen tussen de voorzieningen binnen de GGZ mar moelzam te geven zifn. Zo is het beleidsmatig moeilijk an te geven hoe ernstig de klacht moet zijn wil een behandeling in de RIAGG geindiceerd zijn en niet in de huisartspraktijk of in het Algemeen Matschappelijk Werk (zie de nota Geestelifke Volksgezondheld, 1984 en Hodiamont e.a., 1986): analoge problemen liggen er m.b.t. het welzijnswerk, de (algemene) gezondheidszorg en het justitielel apparaat.

Concluderend mag gesteld worden, dat de algemene GGZ-doelstelling, de gerichtheid op geestelijke gezondheidsproblemen (zie Rome e.a., 1981) voor professionelen in aanpalende beroepsgroepen en voor leken onvoldoende geoperationaliseerd is. Julst dit geeft an dat de GGZ als institutie nog niet uitgecristalliseerd is (Brinkgreve e.a., 1979). Enerzljds is deze onduidelifke situatie toe te schrijven an onvoldoende bekendheid met de GGZ, anderzijds kan ook gesteld worden dat de GGZ als matschappelijke lnstitutie nog lang niet gefixeerd is; welke gespecificeerde doelen dient zij na te streven en welke functies dienen dus a anwezig te zijn? Deze onduldelijkheid zal, zoals ik nog zal laten zien, consequenties voor de toekomstige GGz hebben.

\subsubsection{Centrifugale en centripetale krachten}

Herboven heb $1 k$ al beschreven dat er in de GGz vele behandelingsmethoden bestaan. Het aantal wordt steeds groter: steeds worden er nieuwe technieken ontwikeld (b.v. sociale vaardigheidstrainingen, zie ook Beckers, 1986 en Beekers, 1982). Om een voorbeeld te noemen: de ontwikkelingen binnen de OEP (organlsatorische eenheid paychotherapie) voorheen het IMP, een voorziening die in 1940 in Amsterdam ontstaat (de Swan, 1979; Brinkgreve, 1979) als een instelling om oorlogsalachtoffers in psychische zin de helpende hand te reiken. Er verd in deze voorzlening ultsluitend psychoanalytisch behandeld. Bezien wj en hedendaagse wilekeurige OEP dan $1 \mathrm{~s}$ de gegroeide differentiatie groot; de keuze is anwezig tussen oen individuele 
theraple op pischoanalytleche $\$ 2 *$ danwel een andere psychodynamische bas 1s of op leertheoret Ische basis. Er vorden groepstheraplez (met de nodlge therapeutische differentlaties) gegeven: voorts zijn er nog gezing- en echtpar-(relatie)-theraplecn.

Het OEP sat in deze ontwkelingen niet alleen. In andere voorzieningen, b.v. het APZ (Algeneen Psychlatrisch Ziekenhuls), zijn analoge ontwikkelingen zlchtbaer. Uit het APZ zijn tijdens een jarenlang proces de zwakzinnigen, de geriatrische patiznten en de verslaafden goeddeeli "weg georganleeerd" voor deze groepen kwamen categorlaal werkende inistellingen. Vervolgens is er een verdere differentiatle ontstaan nar teams, behandelunits en afdelingen ieder met hun eigen taak geformuleerd in termen van patientkenmerken, behandeldoelstelling en mogelijkheden. Maar ook binnen de kleinste enheden heeft men zich verder gespectallseerd. Dit gebeurde soms in de vorm van elgenstandige onderafdelingen, mar vak in de vorm van bijdragen vanult de afzonderlijke disciplines, warbinnen gandeweg specialiat les ontstonden.

De GGZ, die goeddeels vanult het particuliere inltiatief ontstan is In en verzullde samenleving, werd tot een twintigtal jaren terug gekenmerkt door nast elkar bestaande enheden welke onderling geen of weinig contact hadden. Sturing vanuit de centrale overheid heeft in de jaren zeventig geleld tot meer samenhang in de regional Bedachte (A)GGZ. Momenteel is het resultaat van deze bemoelenis te zien in het bestan van de RIAGG, die een bundeling is van IMP, SPD, MOB en LGV-bureau's. Een ander product van dit overheidsstreven is de RIGG warln de grotere GGZ-voorzieningen in een bestuurlijk verband Gebracht zijn (zie 0.a. Jacobs, 1984).

Dit overheldsbeleid is als een centripetale kracht te beschouwen, maar daarnaast wordt het overheidsbeleid ook door -al dan niet vooropgezette-centrifugale krachten gekenmerkt. Een voorbeeld is de wens van de overheld de tussenvoorzieningen samen te laten gaan in de regionaal opgezette RIBW en niet in de RIGG warin de grotere en kleinere broers participeren en van waruit de tussenvoorzieningen soms zijn opgezet. Ook de verschillende financleringsvormen ondersteunen bepald niet altifd de samenwerkingsinitiatieven (o.a. Jonkman, 1984). Bovendien zijn er tendenzen in het overheidsbeleid zoals b.v. de anzetten om tot een integrale jeugdhulpverlening en en Integraal ouderem-beleld te komen, warblj onderdelen vanuit'de GGZ veer naw gelleerd gedacht worden an andere instituties. Ook de kennelijke wens om de hulpverlening lnzake psychosoclale problemen in de eerte $11 \mathrm{jn}$ te latem plativinden $* 3 *$, geeft bl $1 \mathrm{jk}$ van en centrifugale kracht ondat delen van de GGZ nauwer dienen samen te werken met le lijnsvoorzieningen, ten behoeve van de daartoe noodzakelijke (en ult te bouwen) consultatiefunctie. 
In een recent artikel vat Crombag (1986) enkele ardige gedachten samen onder de titel 'de eeuw van het beleld'. Hif merkt op dat de zaken tegenwoordig planmatig angepakt dlenen te worden en dat deze premisse noolt ter discussie staat. Hij slgnaleert deze planmatige anpak op het nlveau van het individu, mar nog sterker op het niveau van collectiviteiten: de mens vreest chaos. Echter wij mensen $z i f n$ beperkt: "De aspiratie nar generale rationalitelt van verstandelfjk beleld loopt stuk op onze beperkte aandachtsspanne en de complexiteit van een wereld war in principe alles met alles samenhangt." (Ibid, p.22) Doordat individuen niet veel verder komen dan een vorm van locale rationalitelt resulteert het collectief beleid hoogult in een vorm van globale rationaliteit.

Ondanks het feit dat beleidsplannen geen realiteit worden, blifven wij beleid maken of stelien ij de oude plannen bij. De schrik voor chaos is zo groot dat wij blijven streven nar universele rationaliteit met telkens nieuwe profeten (nu de informatici; ibid). In deze analytische redenering die Crombag leent van v.Gunsteren (1976) staat de tegenstelling tussen beleld gebasererd op de universele rationaliteit en de resultaten van de lokale rationaliteit van individuen centraal. Kortom beleid dat gebaseerd is op universele rationaliteit, is slechts mogelijk, indien ook individuen er een dergelijke rationaliteit op na houden. Echter, daartoe zou volledig gedetermineerd (sociaal) handelen van individuen noodzakelijk $\mathrm{zijm}$. En zover zijn wij als soort (Belukkig?) niet.

Het werken in en rond de GGZ wordt uiteraard eveneens gekenmerkt, door beleidsvoerlng op alle niveau'si. Op overheidsniveau heb ik zojuist al enkele beleidsijnen angegeven: op (inter- en intra-) instellingsniveau geldt hetzelfde. Dit uit zich alleen al in de grote toename an antallen beleidsmedewerkers in de GGZ gedurende de afgelopen decennia.

Het al angegeven algemene probleem inzake het bereiken van universele rationaliteit in het te voeren beleld, lifkt in de GGZ nog problematischer vanwege het gedrag van individuen -hulpverleners en consumenten- dat nog minder deterministisch dan in andere sectoren $11 \mathrm{kt}$.

\subsection{De GGZ als collectieve zingever?}

A1 erder heb ik betoogd dat de GGZ als een sociaal systeem, en als een cultureel systeem beschouwd kan worden. Als cultureel systeem, als een geheel aan warden, normen, verklaringsmodelien en duldingsvormen, is de GGZ uitgestrekter dan als sociaal systeem: immers ook Individuen die niet rechtatreeks met de GGZ als social systeem te maken hebben, hanteren in meer of mindere mate de "GGz-kijk" orm problemen een zinvolle plaats in het leven te geven.

In het voorafgaande hoofdstuk heb ik psychlsche gtoornis als volgt gedefiniëerd; een onvermogen om dusdanige sociale handelingen te 
laten platavinden dat aan de directe Interactie of an de sociale relatie wederzijds zin verleend wordt. Een GGz-behandeling is dan primatr te bezlen als en aciale handeling varin alsnog gepoogd wordt tot een compatibele zlngeving tussen geldentificeerde patient en het relevante deel van diens omgeving te komen. Hulpverlener en patidnt dienen tot overeensteming te geraken (zle ook Dormar e.a., 1986): het gat erom hoe zij belden zin geven an hum sociale relatie die men theraple noent. De contie hiervan is dat langs de weg van het instrumenteel rationalisme het individu gecompenseerd wordt voor zaken die in het leven misliepen. Het individu moet hiervoor een deel van zijn priveleven prijsgeven: op macro-nivo wordt hierdoor amengestelde gelijkheid gerealiseerd. Tenslotte zij erop gevezen dat aldoende delen van het menselijk handelen die voorheen niet planbaar, niet boheersbaer, etc. waren, dat nu wel zifn. Met andere woorden, met behulp wan het instrumenteel rationalisme $z i j n$ grotere prestaties wat betreft complexiteitsreductie mogelijk geworden.

\subsubsection{De GGZ gevangen in de matschappelifke context}

Waar $1 k$ hier aandacht an wil besteden is het gegeven dat behandelingen in de GGZ platsvinden binnen een culturele context die per definitie beperkingen oplegt.

In de voorafgaande paragraaf heb ik angegeven dat een GGZ-behandeling gezien moet worden als een sociale relatie, als een interactiesysteen, waraan beide actores, de hulpverlener en de patiênt, een eigen zingeving proberen te geven. Voor de hulpverlener gat het In dit spel erom dat hij zin kan geven an het gedrag van de patient In deze situatie en wel zodanig dat dit gedrag past in het paradigma van de hulpverlener: evenzeer hoort daarbij dat de hulpverlener zijn zingeving, zijn verklaring overdragt of vertaalt mar zijn tegenspeler, de patisnt.

De gewenste complexiteitsreductie die anvankelijk niet kon platsvinden, omdat incompatibele attituden niet leiden tot wederzijdse zingeving in het dagelijks leven, dient al zoekend tot stand te komen tijdens de theraple. Hoewel hulpverleners inventieve mensen blijken, blifven zif van ons voort. Zlj worden evenzeer als wij bepald door hun elign context. Ook hun attitudesysteem heeft beperkingen; hulpverleners kunnen mar beperkt buiten de werkelijkheid, zoals wij die matschappelijk gedefinieerd hebben, treden. En hun poglngen tot zingeving zulien gebaseerd zijn op onze werkelifkheld, op onze matachappe11Jke normen omtrent normaliteit, functioneren, etc., en zulien dientemgevolge erop gericht zijn de patient onze werkelijkheid 1s werkelijkheld te doen accepteren. Mar niet alle patienten zullen hiertoe (blijvend) over te halen zijn, ondanks alle steeds meer "geavanceerde technleken", Juist ondat het uitgangspunt-gelegen in de definitie van de sociale relatie- niet wezenlifk verandert. pie patidnten noemen wij vervolgens chronisch. De matschappelijke kwetsbaarheid voor delen van de populatie en de 
relatie van kwetsbarheid en het ontstan van psychlsche stoornissen verdient nog kort andacht. Soclale relaties, sociale interacties, attituden en zingeving (inklusief verkelijkheidsbeleving) horen onverbrekelijk bij elkaar: ook macht past in dit r If te. Daaruit kan geconcludeerd worden, dat 'machtelozen' in de meest brede $z$ in per definitie gevoeliger zijn voor het ontstan van psychische stoornissen, julst ondat zif -op alle niveau"s, mas vooral op die niveau's warop hun machteloosheid het scherpst natr voren komt- het minst in staat zijn (mede) hun definitie van de verkelifkheld ingang te doen vinden, hun zingeving door anderen geaccepteerd te krijgen. Deze logische aflelding platst de GGZ als matachappelijke institutie voor een onoplosbar dilemm. Immers hieruit komt naar voren dat het principe van samengestelde geligkheid berust op het geven van compensatie voor a anwezige ongelifkheld en niet op het teniet doen van die ongelijkheid.

\subsubsection{Vraag en anbod: over protoprofessionalisering}

Over vraag en aanbod, over "oneindige behoefte, onelndige zorg" is al veel afgepraat en geschreven. De eerste constatering dat er veel meer mensen psychiatrisch zlek zifn dan er werkelifk in behandeling zifn, is al oud en wordt a angeduid met de term 'ijsbergfenomeen': later kon dit telkens opnieuw empirisch vastgesteld worden, hoewel de verhouding de nodige variatie kent. Het punt is, dat behoefte aan zor $\mathbb{B}_{\text {, }}$ aan GGZ-behandeling lets anders is dan het hebben van een psychische stoornis. Het hebben van een psychische stoornis kan wel objectief en betrouwbaar, onder aantekening dat ons meetinstrument cultureel gegeven is, vastgesteld worden. Bij het vaststelien van behoefte an zorg doen zich enkele fundamentele problemen voor: behoefte wordt door verschillende factoren bepald. De ernst zoals die door de pationt of diens omgeving ervaren wordt, is slechts een van de factoren. Daarnast zijn te moemen: bekendheid met de GGZ als institutie en als ijze van denken warmee bepaalde problemen opgelost kunnen worden, de mate van vertrouwen in die institutie en denkwijze, eerdere ervaringen darmee, etc..

De Swaan en anderen (de Swaan e.a., 1979; Brinkgreve e.a., 1979; de Swan, 1984; Dosterbaan zeldenrust, 1985) hebben argunenten en empirisch materiaal bijeen gebracht waruit de anwijzing naax voren komt, dat de mate van proto-professlonalisering bepalend is voor de mate van behoefte an GGZ. Wellicht hangt dat ook samen met de mate van behandelsucces. Daarbij kan vermeld worden, dat succesvolle behandelingen niet persé tot minder (toekomstige) behoefte zullen leiden: integendeel, indien nieuw ervaren problemen zich voordoen zal een sterkere behoefte zich doen gevoelen.

Tenslotte ijs ik erop dat juist omdat de GGz la denkwjze, als cultureel verklaringsschema in de hogere en in de middenklasse $* 4 \star$ ontstaan is -en mar geleidelijk "naar onderen zal druppelen"- in eerste instantie weinig bekend zal zijn c.q. Weinig succes kan boeken bif diegenen warvan theoretiach verwacht mag orden dat $z$ ij er het 
neest latent behoefte an hebben. Anders gezegd: de GGZ zal als inatitutle al atevig matschappelifk verankerd moeten $z i j n$, wil $z i j$ ook die categorlesn berelken die har het hardst nodig hebben. Pas dan kan de GGZ als inatitutie optimaal werkzaam zijn in het (mede) bewerkstel1 $1 \mathrm{gen}$ van samemgestelde gelijkheid.

\section{5. cGz: hoe nu verder?}

Mifn formele beschrifulng van de GGZ loopt hier ten elnde. Enkele i1jnen, die in de naaste toekomst van belang kunnen zifn, wil $1 \mathrm{k}$ nog kort angeven.

In dit hoofdstuk heb lk laten zien - in navolging van andere auteursdat de GGZ zijn start had in de behandeling (de verzorging) van die personen die wij tegenwoordig chronisch psychiatrische patienten noemen; persomen warblj sprake is van dusdanige handicaps dat normal functioneren slechts moeizaam of in het geheel niet meer mogelijk is.

De buidige GGZ wordt echter gekenmerkt door het gegeven dat mar ten dele een oplosing $\star 5 *$ gevonden is voor deze groep patienten. Dit, terwijl in vergelifking met de beginfase van de GGZ het hulpaanbod en ook de totale patientenpopulatie -zowel in absolute aantalien (en per 1000 Inwoners) alsook naar verdeling van de aangemelde psychische problematiek- sterk veranderd zIjn. De GGZ behartigt nu meer geindividuallseerde, mas in oorsprong matschappelijke in het social handelen tot uiting komende, problemen dan vroeger. Dit is mogelifk omdat een instrumentarlum ontwikkeld is on aanvankelijk ongedefinieerde problemen als psychische problemen te kunnen benoemen.

\subsubsection{Het kernprobleem van de GGZ: chroniciteit}

Alleen het omlijnen van chroniclteit als theoretisch begrip en het empirisch bepalen als verschijnsel rechtvaardigt een studie op $z i c h$. Ik refereer an de eerder geformuleerde definitie, warin twee criteria verwoord werden: het eerste luidt dat het gat over GGZ-patienten. Ten tweede, het betreft individuen waarmee geen biljvende wederzljdse zingeving angaande het sociaal handelen kan plaatsvinden. In deze $z$ In 1 de GGz een deel van het spel "chroniciteit" warbif de GGz matachappelijk gezien een sociaal geaccepteerde zin tracht over te brengen, maar daar noodzakelijkerwijs blj een aantal Individuen in falt. Dit falen wordt de GGz echter matschappelifk opgedrongen: de norm lnzake zingeving, realiteitsbeleving 1 igt primair sociaal verankerd *6*. Een emancipatie van b.v. psychotische Bedragingen als een gelifkwardige variant is in onze westerse samenleving, gebseerd op een lnstrumenteel rationalisme, moeilifk denkbaar. Dit omdat onze samenleving gekenmerkt is door lange athankel 1 kheldsketens warbij het sociaal handelen sterk (intern) Benormeerd dient te verlopen. Daarin 1 lgt de reden dat de mate van terugval in socile rolien bij ons groter is dan in de $z \cdot B$. prinitleve samenlevingen; de "traditionele psychiatrische patient. 
kan an de strakke (intern te verwezenlifken) nomerling maar moel11jk voldoen en hif is meer dan wle ook het slachtoffer van een samenleving dfe is gerleht op planbarheld en op makbarkeld.

Opheffing van chroniciteit is dan ook slechts op twee wljzen denkbaar. In de eerste plaats: letterlifk door te concluderen dat de GGZ juist in datgene wat har ontstaanggrond was, gefaald heeft. Darom zou men de traditionele psychlatrische patient moeten laten wat hij feitelijk is, n.1. een deel van de (onbegrepen) omgeving van de samenleving. Hierbij hoort de antekening dat deze personen nlet an hun lot overgelaten mogen worden of dat zij ult de samenleving gestoten dienen te worden. Het alternatief moet daarin gezocht worden, dat het kennelijk mogelijk is warlanten in delen van het gedrag te accepteren. Abstract geformuleerd betekent dit dat alleen en deel van het gedrag tot omgeving gemakt wordt. We moeten darbif bedenken dat wij in wezen alleen problemen hebben met bepalde aspecten binnen het sociaal handelen van deze individuen; voor wat betreft andere aspecten behoeft er niet zoveel an de hand te zijn. Juist daarom is het langzamaan mogelijk te werken an de emancipatie van deze afwijkende varlant in het soclaal handelen: een nieuwe taak voor de GGZ? Wat daarnast resteert voor de GGZ is dan belangenbehartiging in plats van behandeling, warbij die belangenbehartiging niet alleen op het individu gericht zal moeten zijn, marar ook structureel, matschappelijk vorm dient te krijgen.

In de tweede plats is opheffing van chroniciteit denkbar door verder te zoeken naar een mogelijkheid de patiknt te transformeren en hem alsnog tot 'rede' te brengen.

De keuze tussen beide mogelijkheden lifkt mij ulteindelijk meer een vraag voor de ethiek dan voor de GGZ: gezien de stand van zaken heeft de eerste richting wellicht meer kans realiteit te worden dan de tweede. Voor de GGZ echter resteren andere (wellicht meer succesvolle) taken.

\subsubsection{Verschuivingen in de invulling van de doelatelling}

De algemene doelstelling van de GGZ is het verbeteren van de qualitelt van het bestaan van paychlatrische patienten. Echter, deze doelstelling is breed en wein concreet en $1 \mathrm{~g}$ vooral an veranderingen onderhevig op het moment dat de definitie van de 'psychiatrische patient" (dus de criteria inzake "caseness') verandert. Bovendien wordt de invulling van de doelstelling mede bepald door de anwezlge technologle; bij uitbrelding van de techniek kan 'het verbeteren van de qualiteit van het bestaan" een andere inhoud krijgen en kunnen de doelgroepen -wie noemen we cen casus- veranderen.

Veel van de ambulante zorgvormen zijn begonnen met als doel terugual van ontslagen patienten te voorkomen (nazorg) n het ontstaan van (ernstiger vormen van) psychische stoornisisen tegen te gaan. Gaandeweg is er steeds meer belangsteling gekomen voor verbetering van de geestelijke gezondheid van de populatie. Binnen deze stroming, die in Amerika begon onder de benaming 'mental health movement" is 
men in Nederland langs verzullde $11 \mathrm{jnen}$ overgegaan tot de oprichting van diverse ambulante zorgvormen.

De meeste van deze (ambulante) zorgvormen vallen nu onder de geestelijke gezondheldszorg $\star 7 \star$ en worden als zodanig gefinancierd. Met de ontwlkeling van deze ambulante zorgvormen, als organisatie en als methodische verkorm, breidt het onderwerp, het objekt van de GGZ alch ult: er vindt een verschuiving plaats. In de loop der tijd worden vooreerst een aantal (mis)gedragingen tot object van de GGZ gemakt die dat voorheen niet waren. Vervolgens wordt de grens van wat nu als noodzakelijk te behandelen geacht wordt opgeschoven, wardoor de "gemiddelde ernst" van de te behandelen stoornis minder wordt.

Hoiewel momenteel onder druk van de monetaire stuatie (en en daaraan Bekoppelde nleuwe ldeologle) gepoogd wordt een deel van de huldige patientenpopulatie (met name de minder ernstige stoornissen) terug te platisen blf de le $11 \mathrm{~J} n$, kan erop gewezen worden, dat de GGz als cultureel systeem, als denkmodel zich sterk lijkt uit te breiden o.a. in die le lijn, mar ook in de gehele samenleving.

Tenslotte wil lik erop wifzen, dat er vanuit de GGZ -of onderdelen daarvan- claims gelegd worden richting somatische gezondheidszorg: men pretendeert een antal zaken te kunnen oplossen die daar (onnodig) behandeld worden (zonder feitelijk resultaat) en men denkt daarbij kostenbesparend te kunnen werken (mar uiteraard betekent dit ook een kostenverschuiving van de somatische gezondheldszorg naar de (GGiz).

\subsection{Samenvatting en conclusieg}

Dit hoofdstuk kreeg een a arvang door te stellen dat de GGZ onze manier is om met 'gekte' om te gaan. Vanuit die stelling ontstat de verplichting on op verschillende niveau's te tonen hoe de relatie tussen de GGZ -als een manler van denken en als vorm gegeven in voorzieningen- en de samenleving eruit ziet; hoe de een de ander beinvloedt. Uiterasd ben Ik mij ervan bewst dat hier de relatie tussen de GGZ en de samenleving maar velnig gedetallieerd beschreven is. Echter, in dat korte bestek heb lk laten zlen dat, hoewel het begin van de GGZ wel bil het ontstan van de stat (zoals wis die hier in het westen kennen) geplaatst wordt, de Goz pas goed van draad begint te komen in de negentiende eeuw: in een periode dat ook andere "socla le verdichtingen" (onderwijs o.a.) vorm krljgen. Het "ardige" van de Nederlanse stuatie 10 dat die verdichtingen ontstan vanult het particulier inftatief dagrin ligt de oorzak van en sterke groel en differentiatie in de verzullde samenleving in de eerste helft van deze euw Dit houdt in dat de overheld pas achteraf regelend kom (kan) optreden en dan pas op het moment dat de afzonderlijke enheden tot voldoende grote combinatiea gesmeed waren.

De doelstelling van de GG2 blijkt zeer algemeen en weinig concreet, n1. de zorg voor de qualiteit van het bestaan voor de psychiatrische patint. Het concreet invulien van deze doelstelling geeft anleiding 
tot diverse wegen. De zorg (de middelen, de technleken) kan tot de nodige varieteit anleiding geven. Ontrent de qualitelt van het bestaan zifn weinig, In de tijd stabiele, enduldige criteria te geven: ook veranderingen in de definitie van de 'psychiatrische patient' (de criteria inzake 'caseness') geven aanlelding tot een verdere ultbouw van de GGZ. Tenslotte blijkt dat de aanwezlgheid van verschillende theorien met betrekking tot ontataan van paychische btoornissen geleid hebben tot een grote differentiatie in het zorgaanbod. Pas gandeweg wordt het duidelifker bij welke andoening welke behandeling het meest geindiceerd is.

In het streven nat planmatigheid komt de relatie tussen de GGZ en de context warin zij zich bevindt tot ulting: dit is te zien op het niveau van de voorzlening en op het niveau van meer voorzieningen, b.v. In de vorm van regionale afstemming tussen de voorzieningen. Hoewel de overheid bij dit alles steeds sterker sturend anwezig is, lijkt het ook duldelijk dat hooguit een vorm van globale rationaliteit -in termen van crombach (zie 4.3.3)-bereikt wordt; ondanks onze vrees voor chaos kunnen wij deze niet geheel en al uitbannen, integendeel, soms veroorzaken wij ongewild chaos.

De GGZ is beschreven als een verspreider van instrumenteel rationalisme in een schemergebied van het menselifk bestaan: 'gekte' geheten. Op macro-niveau bewerkstelligt zij een verhoging van de complexiteit in de samenleving. Zodoende giet zif delen van het menselijk handelen in hanteerbare, in beheersbare vormen. Op het niveau van het individu kan de GGZ zorgdragen dat personen met een sechtere geestelijke gezondheid hiervoor compensatie krijgen. De GGZ kan in die zin beschouwd worden als een van de instituties die samengestelde gelifkheid tot stand laten komen met als nadeel het koloniseren van en deel van prive-bestaan.

Tot sllot enkele speculaties over hoe het verder zou kunnen gaan met die GGZ. Daartoe is het nuttig de draad vast te houden dat de GGZ voort komt uit het instrumenteel-rationalisme als leidend cultuurbeginse1. Julst ondat het er sterk op lifkt dat dit beginsel "stevig in het zadel zit' en een hoog nuttighelds-effect kent lis het maar moeilijk denkbaar dat daarin verandering kont. Hoewel dit vanult een cultuur-filosofisch otandpunt negatief te warderen valt (en deze negatieve cultuurkritiek is een leder middels de geschriften van o.a. de Frankfurters wel bekend), schept deze situatie watin het instrumenteel-rationalisme het leven de komende decennia zal blijven bepalen, de nodige mogelifkheden voor de GGZ: dit ondanks de huidige stagnatie voortkomend uit het monetair gedicteerde overheidsbeleid.

Het groelpotentibel van de GGZ moet hoog worden ingeschat en wel vanwege de volgende overwegingen. Aan de aanbodzijde zien wif en varidteit aan technieken, die in grote mate an allerhande problemen gelocaliseerd bij allerhande soorten individuen soelas kunnen bieden: technieken die bovendlen langzaamaan op min of meer gestandaardiseerde wijzen benut (kunnen) worden. Daarnaast is te constateren dat er een toememende organlatorische ervaring a anwezlg is, waardoor 
minstens op pei1 zal kunnen houden. Tenslotte wil $1 \mathrm{k}$ erop wizen, dat de arbeldspool in principe groot is, hoewel er zich fricties t.a.v. het vereiste opleldings- en ervaringsniveau kunnen voordoen. In die zin zullen oplelding, nascholing, e.d. belangrijke issues in de GGZ moeten blifven en zonodig zelf meer andacht behoeven.

Aan de vraagzijde behoeft vooralsnog niet gevreesd te worden voor een "Inzakkende vraag". In de eerste plats omdat nu slechts en deel van de potentie patienten-populatie die in aanmerking komt voor behandeling ook daadrerkelifk een behandeling krigt.

In de treede plaats is het nuttig ons de behoeftenboom van Haslow nog eens voor ogen te halen. Dan blijkt dat individuen, als eenmal aan een antal primaire zaken tegemoet is gekomen, behoefte hebben als mens ook in social en psychisch opzicht te groeien. zolang wil in Nederland qua levensstandaard niet oterk terugvallen, zal de behoefte an GGZ -voortkomend uit een vens het sociale en psychische welzijn te verhogen- eerder toenemen; zeker indien bedacht wordt dat de bekendheid met de GGZ door processen van protoprofessionalisering toe zal nemen. Deze factor sluit overigens aan bif ontwikkelingen in de GGZ tijdens welke de criteria inzake 'caseness' anders, breder geformuleerd worden.

Tot lot breng $1 \mathrm{k}$ de lezer nogmals in herinnering dat de GGz -nast andere instituties- een belangrijke stabliserende functie in de samenleving heeft namelijk het bewerkstelligen van samengestelde gelifkheid. Het loslaten van dit beginsel lijkt erg onwaarschijnlijk, omdat het geworteld is in de basis van onze samenleving. Hierin immers komt onze specifieke vorm van solidariteit naar voren. Bovendien is het beginsel van samengestelde gelijkheid vooral vanaf het midden van de vorige eeuw steeds duldelijker matschappelijk geconcretiseerd.

Zijn er ook zwakke kanten te constateren? Die zijn er te over. Bijvoorbeeld, in de huidige situatie warbij steeds hogere qualiteltsen doelmatigheidseisen gesteld worden in een periode van krimpende middelen, wardoor het moeilijk is alle beloften war te maken. Maar atructureel zifn er ook enkele twijfels te signaleren. Een korte opsomming levert de volgende punten: 1) een onduldelifke en ongelijke financierligsstructuur; 2) de gestelde doelen worden niet altijd gehald (ofwel de pretenties waren en zijn weleens te groot Bebleken): 3) de van tijd tot tijd ontstane 'modellenstrijd' en tenslotte 4) het gegeven dat de wortels van de psychiatrie, van de GGZ en dile van de geneeskunde niet dezelfde zijn (Neff e.a., 1987), terwild de GGZ $21 \mathrm{ch}$ als gezondheidszorg presenteert. Dit is nlet vreemd, daar dit voordelen inzake financiering, legitimatie, matschappe $11 \mathrm{jk}$ prestige, e.d. heeft. Hoewel men in de GGZ mede werkt vamult het medisch model en dit model de boventoon blijft voeren (Gle1, 1982), kan men niet zonder de andere modellen. Dit blifkt ook ult de geschiedenis van de psychiatrie, warbij zelfs gesteld zou kunnen worden dat psychiatrie in eerste instantie ontstan is vanuit een algemene humanitair gevoede ethlek in plaats vanult een technische invalahoek: hoewel de techniek al snel een belangrijke rol 
speelde. Deze innerlijke gespletenheid levert een onduldelijk beeld op voor de buitenwacht en versterkt de tegenstellingen tussen (onderdelen van) voorzieningen.

Tot slot een punt dat door velen wellicht als een nadeel voor de GGZ gezien wordt. Het huldige overheidsbeleid is erop gerlcht een deel van de vraag in de le $11 \mathrm{fn}$ te laten afhandelen. Het effect van dit beleid is op korte termijn een uitbrelding van de GGZ -al cultureel systeem- in de populatie en daardoor op lets langere termifn een vergrote vraag naar meer GGZ als sociaal systeem, met andere woorden een vergrate vraag naar specialistische GGZ-hulpverlening $t . g . v$. de proto-professionalisering die door de le 1 ifn als proces versterkt is. 


\section{HOOFDSTUK 5}

\section{BEN BRDG: VAN THEORIE NAAR GMPIRTE}

\section{1. Inleiding}

Dit hoofdstuk vormt de schakel tussen het eerste en het tweede deel van de bundel. In het tweede deel wordt de GGZ langs enkele invalshoeken empirisch bezien. Ik zal hier een aatal theoretische aspecten zoals die in de voorafgaande hoofdstukken aan de arde gesteld zijn, omzetten in te toetsen hypothesen.

Het hier gehanteerd thema bestaat daarin, dat kennis van de GGz als een matschappelifke institutie om problematische vormen van sociaal handelen alsnog invoegbaar te maken, ons lets zal leren over de matschappij warin deze institutie vorm heeft gekregen. Tegelifkertijd dient onderkend te worden dat kennis over de GGz niet mogelijk is zonder kennis over de samenleving warin zij vorm kreeg.

Ik 11 de GGZ langs drie lnvalshoeken beschrijven. In de eerste plaats formuleer ik verwachtingen omtrent de vorm van de GGZ: naar het soort voorzieningen en functies en naar de aantallen individuen die in contact komen met die voorzieningen en functies. Specifiek zal ik hier beredeneren dat de GGZ in een regio sterk op die in een andere zal lifken.

In de tweede plaats zal ik aangeven, dat er in een samenleving, die berust op het instrumenteel rationalisme, gekeken wordt nar de wijze warop functies uitgeoefend worden. In een dergelifke samenleving zal men proberen zodanig te werk te gaan, dat meer effect bereikt kan vorden, liefst met minder middelen. Dit betekent dat er, ook gedurende een relatief korte periode van vijf a tien jaren, ontwikkelingen in de GGZ te constateren zullen zijn. Deze ontwikkelingen, die in de richting van een toenemend rationalisme en derhalve in de vorm van grotere onderlinge afstemming tussen de GGz-voorzleningen gaan, kunnen vooraf aangeven worden.

In de derde plats, is uit de theoretische besplegelingen af te lelden welke groepen in de samenleving meer dan anderen en beroep op de GGZ zullen doen: namelifk die Broepen die meer dan anderen op compensatiemechanismen angewezen zijn or zodoende te kunnen 'profiteren" van onze rechtvardige verdeling in de vorm van samengestelde gelijkheld.

\subsection{De GGZ als matachappe1ijke functie}

In vergelijking tot een a antal decennia terug kan het GGZ-aanbod in Nederland rijk en divers genoemd worden; dit gaat ook op in vergelifking met andere (westerse) landen. Verwacht mag worden, dat het asntal personen dat in Nederland bif de GGZ in behandeling kont 
relatief groot is en dat de totale pationtenpopulatie over een reeks voorzleningen verspreld zal zijn. Het merendeel van de patienten zal ambulant behandeld worden; in vergelljking met vroeger is vooral deze 'ambulante populatie' aterk in orvang toegenomen, tervijl het aantal paychiatrische bedden in vergelifking tot vroeger minder veranderd 1.).

Toch blifkt ook bif een dergelijk relatief omvangrifk aanbod, dat maar een fractie (te schatten op 10 a 14 procent) van alle psychopathologie (op jaarbasis) bif de GGz in behandeling komt. Dat deze fractie in de tijd gezien groter is geworden, valt toe te chrljuen aan een vergroot hulpaanbod, van vooral de ambulante aktor. In het voorafgaande hoofdstuk heb ik beschreven welke voorzieningen in de loop van de afgelopen decennia bij gekomen zijn. In die zin kan gesteld worden, dat het hulpaanbod de behoefte aan GGZ-voorzieningen bepanit.

Echter, ook kan gesteld worden dat er een latente behoefte in de populatie anwezig (geweest) moet $z i j n$; anders was hulpaanbod niet vertaald in anspraak op GGZ. In hoofdstuk 3 (Intermezzo; het menselifk handelen) is getoond, dat onze samenleving in toenemende mate gekenmerkt wordt door het instumenteel rationalisme, maar ook dat dit een seeds grotere afhankelijkheid van een persoon t.o.v. vele anderen schept. Tegelifkertijd zien we in toenemende mate een niet-kunnen accepteren van gebeurtenissen en situaties die in het leven mis gaan. Met de ontwikkeling van nleuwe technieken en vardigheden, die alleen door gespecialiseerde personen toe te passen zifn, worden if in toenemende mate van deze specialisten afhankelifk. De GGZ is een plaats in de samenleving war speclalisten 'gehuisvest' zijm: zo worden wij in toenemende mate ook van de GGZ afhanke 1 ijk.

In dit proces heeft de zich ontwikelende professie een niet te onderschatten rol gespeeld. Dat is duidelifk $* 1 *$, mar deze ontwikkeling geldt voor meer professles. Maar ook is duidelijk dat de voedingsbodem voor dit proces, in de westerse wereld aanwezig was; in het verzullde Nederland blijkt deze bodem zeer vruchtbar te zijn geveest.

\subsubsection{De verschilien in de ruimte geminimaliseerd?}

Het is nlet verwonderiljk, dat ontwikkelingen in de GGZ in de westerse landen zovele paralellen vertonen. Immers, culturen, die ateeds dichter nar elkar toegroelen vanwege een algemeen en zlchzelf bevestigend culturuprincipe, gaan in sterke mate op elkar lifken. Mede door een grote communicatieve ultwisseling mag verwacht worden, dat binnen deze culturen eenzelfde soort afhanke11 khe 1 dsketens zullen ontstan.

De verschillen die anwezig zijn, zullen grotendeels op regionale historlsche gronden te herleiden zijn. En zij hebben van doen met min meer toevaliige fluctuaties in het ontwikkelingsproces. zo kon 
v.d.Grinten (1987) opmerken, dat in de ons omringende landen met een zekere afgunst gekeken werd nar het tot stand komen van een belangrlJk gelntegreerd deel van de ambulante GGZ $1 \mathrm{n}$ de vorm van de RIAGG. Tevens kon v.d. Grinten (1987) aannemel1jk maken, dat de RIAGG tot stand kwam dankzij haar voorgangers in een verzullde samenleving: onze RIAGG heeft har wortels in een verzullde samenleving die bij utstek nederlands te noemen 1 s. Dat 11 echter nlet zegsen, dat er ook In andere westerse landen niet eenzelfde tendens anvezig zou zijn, die leldt tot de ontwikleling van een $A G G Z$, integendeel $\star 2 \star$.

Voor nu zij het voldoende op te merken, dat wanneer de GGZ in twee reglo"s van Nederland met elkaar vergeleken worden -op cen tijdstipwif weinig verschilien mogen verwachten en wanneer alt al wel het geval zal zijn, dit te herleiden is tot l) de gevolgde methodieken c.q. verschilien daarin, 2) de reglonale historisch gegroeide situatie en/of 3 ) een liseling tussen voorzieningen wat betreft vergelf kbare functies. Ook verschillen t.a.v. aantallen in behandeling zifnde/komende individuen worden niet verwacht. Verder mag verwacht worden dat slechts een klein deel van de patienten met de Intra- en de semimurale GGZ in aanraking kont.

Concreet kunnen de volgende hypothesen geformuleerd worden:

1. de GGZ in twee regio's zal hetzelfde antal personen (op $6 \mathrm{n}$ tljdstip, gedurende én jaar en lo nleuwe patienten per jaar) in behandeling hebben;

2. de verdeling per regio van de patienten over de echelons zal eenzelfde beeld tonen;

3. de verdeling per regio van de patienten over de afzonder 1 ijke GGZ-voorzleningen zal eenzelfde beeld tonen, en

4. de verdeling per reglo van de patienten naar demografische kenmerken zal eenzelfde beeld tonen.

De toetsing van deze hypothesen vindt in hoofdstuk 7 plaats.

\subsubsection{De verachilien in de tifd gemaximaliseerd?}

In hoofdatuk 4 heb fk al angegeven, dat de GGz als organlsatle sterk in beweging is en, mede onder druk van de overheld, ernar atreft de qualitelt van har product te vergroten. Het beleid in de GGZ is er op alle niveau's vooral op gerlcht meer samenhang in de zorg te krljgen, onnodig dubbelwerk (overlap) te vermijden en de verschillende zorgvormen beter op elkar te laten aansiulten.

Vooral in de jaren zeventig zijn nogal wat atudies gepubliceerd, warult bleek dat er veel aan de GGZ verbeterd moest en kon worden. Het overheidsbeleld is mede op deze studies gebaseerd. Verwacht mag dan ook worden, dat het antal te ignaleren negatieve punten inmiddels in omvang afgenomen zal zijn: ik verwacht met een tweetal deelstudies te kunnen laten zlen, dat or o.a. een grotere samenhang in de afsteming van de zorg t.a.v. elkar bestat en dat er en betere takkfbakening tussen de GGZ-instellingen onderling te vinden 1s. 
De volgende hypothesen zullen in hoofdstuk 8 getoetst worden.

5. De overlap tusgen GGZ-instellingen is in vergelifking met het verleden in sterke mate 'gedekt" door samenwerkingsverbanden tussen die GGZ-inatellingen, en

6. In vergelijking met het verleden is er een duldelifker takafbakening wat betreft kortdurende opnamen in het AP2 en de PAAZ.

\subsubsection{De GGZ: voor weike groepen?}

Psychlsche stoornis heb lk gedeflniterd als een niet perse individugebonden onvermogen om dusdanige soclale interacties te laten plastsvinden dat an de directe interactle of an de soclale relatie vederzijds zin gegeven wordt. Mar in welke situatie en bij welke individuen bestaat or nar verhouding een grote kans dat een dergelijke situatie ontataat? Op dit punt komen wij bij het kernvraagstuk in de psychiatrische epidemlologle en alhoewel dit buiten mifn vraagstelling $11 \mathrm{gt}$, kan $1 \mathrm{k}$ er nlet geheel omheen.

Als eerder angegeven lifkt het erop dat de bevindingen vanult de psychiatrische epidemlologle de voorkeur geven an de hypothese die een et $10 \mathrm{log}$ ische kracht toekent an persoonlijkheidskenmerken en niet an soclale omstandigheden, zoals stress veroorzakende gebeurtenissen en van het netwerk ondervonden steun. Zonder nu al een richting wat betreft de causaliteit an te geven blifft het toch frappant dat b.v. de social-economische status samenhangt met een hele reeks verschijnselen, die lets zeggen over de gezondheidstoestand van Ind Ividuen.

Deze togenstelling lijkt mif weinig vruchtbaar de anzet tot een andere optiek gaf ik eerder (in 3.3.2. en 4.4.1). Alvorens enkele hypothesen te formuleren wil ik die anzet iets verder uitwerken.

In de eerste plaats heb $1 k$ eerder al aangegeven dat nar gelangcognitief, affektief of evaluatief-attitudes van de bif het sociale handelen betrokken actores botsen deviant gedrag een specifieke benoeming en een institutionele vertaling krijgt.

In de tweede plate kan gerefereerd worden a an de door Elias geschetste ontwikkelingen binnen het clvilisatieproces: dit proces wordt gekengchetst door vormen van soclale ongelifkheld warbij de bovenlaag zich wenst te onderschelden. Dit bereikt zij door continu nleuwe gedragsvormen vast te stelien en zodoende haar positie te blljven innemen. Deze gedragsvormen druppelen naar onderen', de lagere klassen nemen deze over en intussen ontwikkelt de bovenlaag alternatieven welke nog niet bif het grote publiek bekend zijn.

Deze voorsprong raakt de bovenbouw per definitie niet kwijt: wat varluert is de omvang van de bovenlaag en de wijze waarop deze samengesteld wordt. In dit proces is 'geld" is al lang niet meer het enlge princlpe dat en rol apeelt. Enerzijds bepalt de bovenlaag in de meest brede zin wat goede 'gedragingen' zijn en anderzijds reserveert $z 1 \mathrm{~J}$ deze gedraglingen voor zichzelf. En al socialiserend zorgt de bovenlaag ervoor dat ook har nazaten prima in het juiste patroon passen $* 3 *$. 
Bij dit alles moet bedacht worden, dat 'goede gedragingen" zich uiten op velerlei terreinen; het leven bestat nlet alleen ult etikette. Ook financien, huisvesting, onderwijs, gezondheld, etc. zijn domeinen, warbinnen men soctaal handelt en warbinnen dit sociale handelen kan mislukken.

Eerder is beredeneerd, dat if personen die nog nlet geheel comme 11 faut" sociaal handelen, compenseren: onze trechtvaralige verdeling van soclale goederen' heet 'samengestelde gelifkheid' en deze kont mede tot uiting in het meer dan toevallig gebrulk van voorzieningen door specifieke categorieen in de samenleving. Dit is danook de kern, wardoor telkens blijkt dat het 'ongeluk', d.w.z. problemen of compensaties hiervoor op welk gebled dan ook, bij dezelfde categorieen in versterkte mate te zien zullen zijn. Deze problemen kunnen zich dus voordoen op het gebied van hulsvesting tot gezondheid, van onderwijs tot justitie.

Een opmerking resteert alvorens enkele hypothesen te formuleren. Wat te denken van een institutie die bedoeld is om samengestelde gelifkheid te bewerkstel1igen, maar juist niet die categoriedn compenseert, die ten anzien van dit punt het aterkst gedepriveerd zijn? Een dergelifke institutie voldoet niet of nog niet an har matschappelifke functie. Mocht dit blijken voor de GGZ, dan zou daaruit af te leiden zijn dat de GGZ als sociaal en als cultureel systeem onvoldoende ingebed is in de samenleving. Dat het noodzakelijk is op dit punt de GGZ te onderzoeken, moge blijken uit een recent onderzoek warult o.a. naar voren kwam dat individuen uit lagere soclal-economische klassen meer geplaagd werden door een slechtere geestelijke gezondheid (en dus op dit punt volgens de heersende cultuur compensatie behoven), mar minder met de psycho-sociale hulpverlening in aanraking kwamen (Raats e.a., 1987).

Dit punt kan getoetst worden, omdat ik er theoretisch vanuit mag gaan, dat de categorién die meer dan andere problemen op bepalde levensterreinen hebben, ook compensatie wat betreft hun geestelijke gezondheid nodig hebben om ook op dit punt tot samengestelde gelijkheid te kamen. Deze algemene uftspraken zijn hier tot onkele hypothesen verbijzonderd: de toetsing van deze hypothesen vindt in hoofdstuk 9 plats.

7. de sociale en de rulmtelijke verdeling van de blj de GGZ bekende psychiatrische morbiditeit is niet toevalili;

8. deze verdeling blifkt in de tijd stablel te zijn, en

9. deze verdeling kan beschouwd worden als een vorm om tot samengestelde gelijkheid te komen en correspondecrt met andere factoren warlangs deze samengestelde gelijkheid wordt vorm Begeven. 


\subsection{Samenvatting}

Dit hoofdstuk vormt een brug tusien theorie en empirie: daartoe werdem een negental hypothesen geformuleerd. Deze zullen in het tweede deel getoetst worden met behulp van gegevens zoals die reglomal bijeengebracht zijn in een gevalaregister voor de geestelljke gezondheidszorg. 
DEEL II: EKA BESCHRIJVING: WERKWIJZE BN RESULTATEM

\section{HOOFDSTUK 6}

\section{ETR PSYCHIATRISCH CASE REGISTER}

Het researchinstrument dat in deze studie het merendeel an empirisch materiaal bijeen gebracht heeft, is plaatselijk bekend als het MHCR: deze afkorting staat voor 'Mental Health Case Register'. Een wat vreemde naam; in de anglosaksische literatuur is de gebruikelijke term 'psychiatric case register', terwijl 'psychiatrisch gevalsregister' en "psychiatrisch casus reglster" goede nederlandse namen zijn. Echter het MHCR is (mede als naam) zo ingeburgerd, dat een naamsverandering onmogelijk 1 ijkt.

\subsection{Inleiding}

Niet alle registratiesystemen zijn registers. Van een register is pas sprake wanneer de volledige en continue registratie van de contacten van de bevolking in een gebied met de GGZ-voorzieningen op een centraal punt bijeengebracht en per patient aneengekoppeld en geordend worden (Brook \& Hamers, 1985; Baldwin, 1973).

Door deze volledige en continue registratie van contacten van de bevolking in een gebied kan betrekkelijk eenvoudig statistische informatie betreffende de aangemelde morbiditeit worden verkregen. Zo kunnen epidemiologische en planningsvragen beantwoord worden, terwijl een register ook gebruikt wordt als zgn. sampling-frame.

Het MHCR als tweede Nederlands register en het noordelijk register * 1* hebben gemeen dat ze an elke bif de GGZ aangemelde persoon afkomstig vanuit het registergebied en die nog niet in het register voorkomt, een zgn. registernumer toekennen. Alle gegevens die in de loop van de tijd van deze personen binnenkomen worden door middel van een reeks identificatiegegevens an de al anwezige toegevoegd (Baldwin, 1973; Wing, 1968).

Een van de belangrifkste argumenten om een tweede reglonal register op te zetten, komt voort uit de vrag in hoeverre resultaten gegeneraliseerd kunnen worden: in een van de volgende hoofdstukken wordt echter Beconcludeerd dat daartoe toch meer dan twee registers aanwezig dienen te zijn. Het lifkt er op, dat de wensen in deze -gezlen de activiteiten in a.a. Rotterdam-vervuld gaan worden.

\subsection{Methode, techniek en mogelijkheden}

In het hiernavolgend - in het engels gestelde- artikel (als paragraaf 6.2 .1 ) komen de start en de opzet van het MHCR aan de orde, waarbif de basisprincipes en een overzicht van de dataverzamelings-, verwerkings- en opslag(beheers)procedures gepresenteerd worden. 
Vervolgens worden in paragraaf 6.2 .2 . enkele recente ontwikkilingen en de comsequenties daarvan voor de huldige stand van zaken aangegeven. Ten slotte wordt in een reeds gepubliceerd engelstalig atuk (hier opgenomen als paragraaf 6.2.3) uitgebreid ingegaan op de (epidemlologische) mogelijkheden van een register. 
RESISTANCE, PRIVACY AND TECHNOLOGY: COMMENTS ON THE NEGOTIATIONS TO ESTABLISH THE CASE REGISTER IN MAASTRICHT

H. FAMERS, M. ROMME and M.W. DE VRIES

Department of Social Psychiatry, University of Limburg, Maastricht, the Netherlands

\section{INTRODUCTION}

In 1980, the Department of Soclal Psychiatry of the University of Limburg initiated a Mental Health Case Register (MHCR) for the region of Maastricht, located in the most southern part of the Netherlands, with a population of approximately 200,000. The effort was sponsored jointly by the Ministry of Welfare, Health and culture, and the University Faculty of Medicine. Ensuring the participation of all mental health institutions in South Limburg was not: an easy matter, since Dutch mental health facilities have the right to function as independent corporations, and are highly diverse in goals and functions. Moreover, in the Netherlands, as in many countries, the central storage of confidential information is a highly sensitive issue: this gave rise to much debate and initial resistance to the undertaking.

\section{ESTABLISHMENT OF THE MHCR}

over a period of three years the copperation of all mental health services was established through negotiation, so that today the MHCR covers all relevant facilities in the "zuid-Limburg" region. The participating organizations from which all patient contacts are recorded (Table 11 are:

1. psychiatric hospital with an outpatient clinic, a day-hospital and three halfwily houses:

2. a psychiatric ward in a general hospital, with an out-patient clinic:

3. all psychogerlatric wards, and a day-hospital for the elderly, in a nursing home;

4. a seven-day, 24-hour crisis interwention service with outreach facllities and a bed crisis unit;

5. a large ambulatory comunity mental health service including a centralized chila guidance programme, a psychogeriatric team, a before and after care programme for chronic patienta, a psychotherapy institute and four decentralized community 
centers where short-term psychlatric treatment and counseling are carriled out;

6. an alcohol/drug treatment programme;

7. an ambulatory service system handing problems of mentaliy retarded people:

8. two priwate psychiatric practices.

TABLE 1

ONE-YEAR PREVALENCE 1981; THE NUMBER OF PATIENTS ACCORDING TO THE FIRST, IN 1981, INSTITUTION CONTACTED (a) AND THE TOTAL NUMBER OF PATIENTS, PER INSTITUTION SEEN IN 1981 (b), PER 1000 INHAB ITANTS *

\begin{tabular}{|c|c|c|c|}
\hline $\begin{array}{l}\text { Organizations } \\
\text { services }\end{array}$ & & $\mathbf{a}$ & $b$ \\
\hline psychiatric hospital & & 4.00 & \\
\hline $\begin{array}{l}\text { beds } \\
\text { day-hospital } \\
\text { halfway houses } \\
\text { outpatient clinlo }\end{array}$ & $\begin{array}{l}1.44 \\
0.30 \\
0.23 \\
2.03\end{array}$ & & $\begin{array}{l}2.29 \\
0.71 \\
0.28 \\
2.63\end{array}$ \\
\hline $\begin{array}{l}\text { Psychlatrie. Ward in } \\
\text { General Hospital }\end{array}$ & & 2.83 & \\
\hline $\begin{array}{l}\text { beds } \\
\text { outpatient clinic }\end{array}$ & $\begin{array}{l}0.25 \\
2.58\end{array}$ & & $\begin{array}{l}0.67 \\
3.05\end{array}$ \\
\hline $\begin{array}{l}\text { Psychogeriatric wards } \\
\text { in nursing house }\end{array}$ & & 0.78 & \\
\hline $\begin{array}{l}\text { beds } \\
\text { day-hospital* }\end{array}$ & 0.78 & & 1.07 \\
\hline crisis intervention centre & & 2.66 & \\
\hline $\begin{array}{l}\text { beds } \\
\text { ambulatory }\end{array}$ & $\begin{array}{l}0.62 \\
2.04\end{array}$ & & $\begin{array}{l}1.60 \\
3.34\end{array}$ \\
\hline $\begin{array}{l}\text { Community mental } \\
\text { health service }\end{array}$ & & 11.65 & 12.31 \\
\hline $\begin{array}{l}\text { Alcohol/drugs treatment } \\
\text { program** }\end{array}$ & & - & - \\
\hline $\begin{array}{l}\text { Ambulatory service for } \\
\text { mentaliy retarded }\end{array}$ & & 3.04 & 3.09 \\
\hline $\begin{array}{l}\text { Private psychiatric } \\
\text { practices }\end{array}$ & & 1.27 & 1.43 \\
\hline TOTAL ONE-YEAR PREVALENCE & & $\begin{array}{c}26.23 \\
(N=53861\end{array}$ & \\
\hline
\end{tabular}

* from Hamers and Brook, 1986, (3)

* not avallable for 1981 
Table 1 shows the 1981 year prevalence and patient inception figures to illustrate the range of services and the total mental health care provided in South Limburg.

Again we wish to underscore that a unique Dutch characteristic of all these facilities is their capacity to function as independent legal entities, with their own management structure and organizational objectives. This sets the Dutoh situation apart from many other countries where mental health care is more closely bound to a coordinated network of services, usually centered upon the hospital.

During the intraductory phase in 1980, resistance to the MHCR was great. We had to satisfy a range of practical criteria set. by the institutions; these criteri were primarily grounded in concern for institutional autonomy and the safeguarding of privacy. These criteria included "

a. Implementation of the MHCR should not bring an increased work load for their staff;

b. registration procedures adopted should not be totally mew or different from those currently in use;

$c$. information gathered would be fed back to them for their own use;

d. no data would be given to third parties without permission of the institution;

e. patient permission for participation must be obtained directly from the subject; non-participation must therefore also be possible:

f. data would be destroyed, or recalled by the institution, if the institution wished it or if a socio-poiltical situation required it.

We conformed to their demands by coupling and interweavipg our registration with pre-existing information-systems, thereby limiting the introduction of new procedures. We also 1 inited the demographic and clinical data collected, thereby minimizing the increased work load on clinical systems.

For privacy and confldentiality we instituted a supervisory oversight comittee in which institutions and patient organizations are both represented. The activities of this group include site visits as well as regular meetings. The supervisory committee prepared a code of rules in consultation with the legal department of the university. which was approved by all parties. 
These rules clarify obligations, rights and procedures for case register operations. They include rules regarding medical confidentlality in psychiatry, and legally binding oath of confidentility for all case register workers.

Technical measures also had to be taken to ensure privacy. wich as separating sensitive "personal" data from more general data not traceable to individuals. The sensitive data, from which patients could in principle be ldentifled, were locked in a safe to which only a few team members had access. This included both disks and handwritten code books. Also introduced were spectal passwords for different functions and a mechanism to detect unauthorized data access. These were discussed, planned and approved by the supervisory committee.

The most important part of the negotiating process, however, was the building of personal and responsible relationships through regular and frequent contact between staff of the MHCR and the various institutions. Continuous and regular contact gradually produced a basis of trust between the MHCR team on the one hand, and the institutions and patient organizations on the other. Nevertheless, before this point was reached, numerous discussions were held with the institutions at virtualiy all personnell levels. During these talks, the MHCR team succeeded in underscoring the unlque capacities of the register - while preserving privacy - for compliing a body of up-to-date information essential for the agencies to monitor, evaluate and plan thedr staffing and services.

Some case register possibilities proved of particular interest. The evaluation and monttoring of services by the MHCR was viewed by the institutions as useful for financial and administrative purposes, including evaluation of crisis centres. They also considered the investigation of referral patterns and patient flow through diverse institutions to be of value for planning efflctent services. During a period of econonic scarcity, the case register, with its potential for faclitating the streamlining of care, appeared as a cost-efective undertaking for the institutions.

These discussions were time-consuming, particularly in the Dutch situation, where mental bealth organizations may be characterized as highly professionalized and democratic. They were, 
however, vital to successful initiation of the register and to maintenance of a continuous, complece and accurate collection of data.

DATA-COLLECTION AND THE DATA BASE

All contacts between the region's inhabitants and any of its mental health services have been recorded from January 1981. In principle, the MHCR is based on the Camberwell register in the U.K. (1) and a register in the north of the Netherlands (2). One reason for establishing the MHCR was to do comparative studies be tween northern and southern Dutch regions. $(3,4,5)$ Registration includes all face-to-face contacts between patients and providers of care, admission and discharge data. demographic information and items such as diagnosis, referrals and type of treatment. $(3,4)$

Identification data collected for every patient are place and date of birth, sex and the first character of the name, but names and addresses are not recorded. A probability link (6) is thus introduced without putting the patient"s anonymity at risk. "The procedures adhered to within the institutions and between these and the MHCR team have been so structured that the institutions" costs of participation are minimized. They are not charged to the MHCR. By 1984 the MHCR included 15,000 patients with 3,000 new entries per year. In order to facilitate feedback to institutions, given these large numbers, an automated data-base system is employed. Investment for the development of this system has been considerable. This outlay was necessary for a system that could process a vast data set rapldyly to provide rapid feedback to the institutions. We are currently able to feed back information to institutions very quickly - sometimes within a week. A schematic overwlew of the MHCR system is presented in Figure 1.

Each institution records and collects the data, but a member of the register team visits at regular intervals and checks for completeness and errors, making correctlons where required. The processing takes place at the register where the data are coded and a register number is attached to each patient. Data entry uses specially-written programmes in Fortran, because of the need for speed and error detection. The computerized filing system is composed of four files:

1. patient record containing treatment and service data:

2. a patient record with demographic data; 

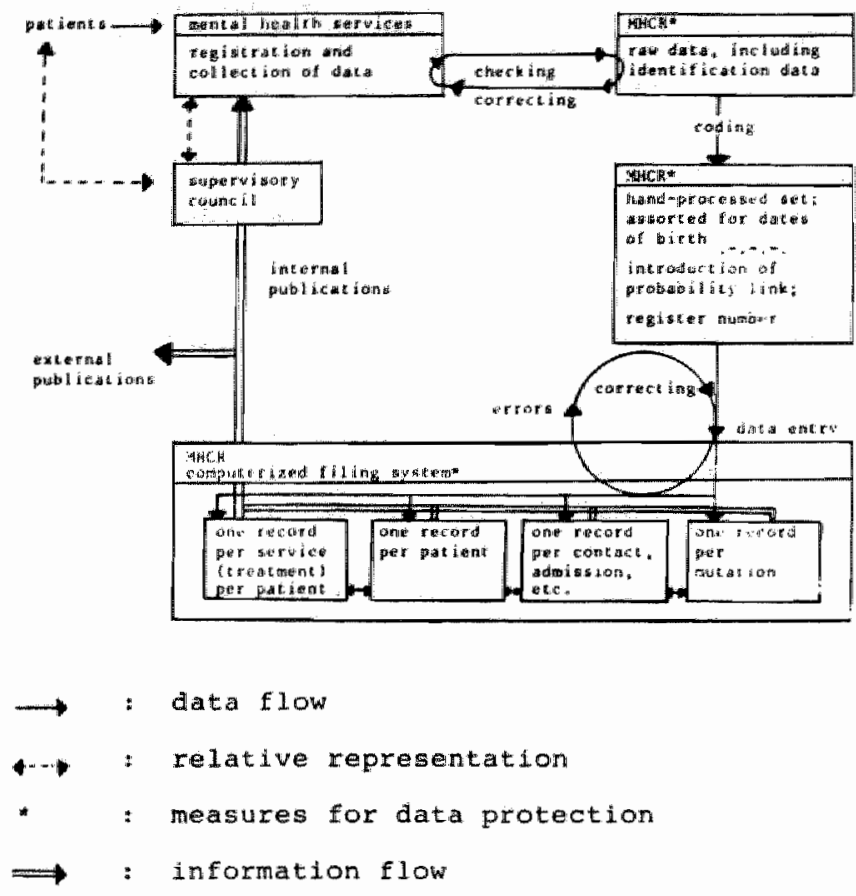

For data entry, checking, output, etc. standard programs in Fortran have been developed.

FIGURE 1

MHCR OVERVIEW 
3. a patient record of contacts, admissiona, discharges (and date of deathl including the service contacted;

4. a patient record of changes in a persons life, for instance divorce from a previously recorded married state, and the date.

There are links between these files and a means of standardizing changes within all files. For research purposes, Fortran programmes are available for determining point prevalence, incidence and year prevalence counts. As required by the code of practice, planned research is discussed with the supervisory committee before starting. Similarly, before publishing, results are discussed with the committee and the service agencies. Internal reports concerning a particular service are sent only to that service.

MAINTAINING THE RELATIONSHIPS

The purely administrative use of the MHCR is ratier dry. It is therefore essential for continuous good work that the interest of the participating institutions be sustained. A major portion of the team's time is, therefore, spent supplying facilities with MHCR information and keeping a high profile. Research questions in social psychiatry also serve a major stimulating function in which the university department plays an important role. A "living" register will keep changing in step with developing facilities and needs for information, in the everchanging perspectives of both science and clinical care. Hence, continual interaction with MHCR institutions is required. Currently we. are discussing the introduction of an all-encompassing diagnostic system, an adapted DSM III. As always, our adage in these deliberations is "progress by negotiation."

\section{REFERENCES}

1. WING, I.K. and HAILEY, A. Evaluating a community pisychiatric service: The Camberwell Registe 1964-1971. London, Oxford University press, 1972 .

2. GIEL, R. and TEN HORN, G.H.M.M., "Een psiychiatrisch register als basis voor planning" "rijdschrift voor socide Geneeskunde. 54, 1976, 148-153.

3. HAMERS, H.J.F.R. and BROOK, F.G., "De GGZ in het noorden en in het zuiden des lands in $1981^{\prime \prime}$, Tijaschrift voor pychiatrie, in press $(1986)$. 
4. BROOK, F.G. and HAMERS, H.J.F.R., "GGZorg gepeild. Een vergelijkend onderzoek met behulp van twee reglsters voor die geestelijke volksgezondheld", Tijdschrift woor Psychiatrie, 27, 1985, 115-127.

5. HAMERS, H.J.F.R., ROMME, M.A.J. and DRIESSEN, G.A.M., "Het (on)bedoelde gebrulk van meer GGzorg-voorzleningen" " $\mathrm{Tijd-}$ schrift voor saciale Gezondheidszorg, 13, 1985, 506-511.

6. BALDWIN, J.A., "Linked recora medical information systems", Praceedings of the Royal Society of London, 184, 1973, $403-420$. 


\subsubsection{Record-1inkage, aystem-management en data-protectie}

In deze paragraf zal ik uiteen zetten, warom het nuttig is de gegevens in de tifd van en en dezelfde pationt cumulatief te verzarelen, op en punt bijeen te brengen en op te alaan. Vervolgens zal ik kort de werkwijze schetsen zoals die ten behoeve van het M.H.C.R. tot stand is gebracht en op welke wijze daarin tegemoet vordt gekomen an de eis de privacy van patient te varborgen.

Allereerst dienen enkele voor de hand liggende felten gememoreerd te worden. Het blijkt dat en deel van de psychiatrische patisnten een langdurige patientcarrière heeft. Veel psychiatrische patisnten maken op een moment in de tijd en in de tijd opeenvolgend gebruik van meer GGZ-voorzieningen: hieraan zitten positieve en negatieve kanten en uiteraard is het beleid binnen de GGz-voorzieningen erop gericht zoveel mogelijk de positieve aspecten te versterken en de negatieve af te zwakken.

Wetenschappelijk is er interesse voor de patientcarrière wat betreft de voorspellende 1tems: welke kenmerken (persoons-, omgevings-, etc.) zifn van belang met betrekking tot langdurige carrieres. Welke momenten in een carrière komen in aanmerking voor een interventie ter voorkoming van verdere of ernstiger vormen van chroniciteit? $\star 2$ *

Beleidsmatige interesse is er ook en wel tweeledig. In de eerste plaats is men erin geinteresseerd welke voorzleningen met elkaar dienen samen te werken, juist andat patiënten kennelifk van deze voorzieningen gebruik maken. In de tweede plaats is men er in geinteresseerd of de wijze warop men de samenwerking georganiseerd heeft de goede is:

Tenslotte moet bedacht worden dat prevalentie- en incidentletelingen van groot belang zijn: deze kunnen echter niet anders dan m.b.v. een register verkregen worden vanwege het optredende dubbelgebruik van de voorzieningen door de clientèle.

Hoe de gegevens verzameld on bijeengebracht worden, is in 6.2.1. uiteengezet. Hileronder zal ik nader ingaan op enkele veranderingen m.b.t. technische aspecten van het M.H.C.R..

De meest wezenlifke verandering die recentelljk is doorgevoerd, behelst de automatisering van de $\mathrm{zgn}$. warschifnlifkheldskoppeling.

Deze koppeling - bedoeld om onder handhaving van de anonfmitelt van de patient (in de zin dat diens naam bif de onderzoekers niet bekend wordt) patientcarrières te reconstrueren en van daaruft ook patientstromen samen te stellen- is gebaseerd op enkele persoonsgebonden items welke feder voor zich onvoldoende, mat gezamenlijk voldoende uniek zijn om de gegevens behorend bijeen en dezelfde patient ook als zodanig te zien en te behandelen. Deze persoonsgebonden items zijn geboortegemeente, geslacht, geboortedatum, eerste letter (geboorte)achternaam en woongemeente.

Het automatisch laten verlopen van de warschijnlijkheidskoppeling geschiedt middels een personal computer warop alle vroeger handmatig 
te nemen beslissimgen nu geatomatiseerd verlopen. De voordelen van deze geatomatiseerde arachijnlijkheidskoppeilng zijn evident. Enerzijds wordt er menskracht bespaard, anderzijds kan de koppeling beter verlopen, worden fouten geconstateerd en hersteld en kunnen ook in het verleden gemakte fouten hersteld worden. Bovendien diende louter uit fysieke overweglngen de automatisering doorgevoerd te worden: dit omdat het bestand immiddels de grens van 20.000 gevallen overschreden heeft.

Een ander voordeel van de 'personal' is dat privacy-gevoelige data nlet onder de handen van het reglsterteam vandaan verdwijnen: deze data blifven immers in de regloterruimte. Een latste voordeel is dat m.b.v. de geautomatiseerd verwerkte en opgeslagen indentificatiegegevens de bestanden op de main-fralm voor een deel aangemaakt en gecontroleerd kunnen worden: immers een deel van de indentificategegevens zijn in beide bestanden anwezig, zoals het geslacht, de woongemeente, het geboortejasr en het (toevaliig) toegekend registernummer. Ook dit punt heeft vele mogelffkheden tot controles gegeven, warvan imiddels dankbar Bebruik gemakt wordt.

Wat betreft de opzet, zoals die t.b.v. de geautomatiseerd op de main-frame opgeslagen gegevens gehanteerd wordt, hebben er ook enkele Ingrijpende veranderingen platagevonden. Werd in de vorige paragraaf -en met name in figuur 1- de werkwijze beschreven die tot en met 1985 werd gehanteerd, hier wordt ingegaan op de situatie van dit moment.

Het grote nadeel van de oude opzet was, dat er tussen de verschillende subbestanden koppelingen gelegd dienden te worden om aldoende bestanden an te maken, warop middels bekende statistische pakketten (als SPSS, SPSSX en BMDP) analyses uitgevoerd konden worden. Het samenstellen van die werkbestanden kostte enerzijds veel cPU-tijd en anderzijds konden deze pas op dat moment op een aantal specifieke fouten gescreend worden. Resultaat was dat controle, foutdetectie en herstel van de fouten in een zeer laat atadium konden plaatsvinden. De oude opzet was destijds-in 1980- gekozen, ondat de verschillende bestanden uit records met een verschiliende recordlengte waren opgebouwd en deze konden toen mar moellijk in 6en bestand ondergebracht worden. Voor dit punt is limiddels -dankzif ontwikkelingen in de programmeer-techniek- een oplossing gevonden, wardoor alle gegevens van eon patient bij elkar ataan. Alvorens de nieuwe data aan het grote bestand worden toegevoegd, worden deze nu vooraf op alle mogelijke fouten gescreend en zonodig gecorrigeerd. Het aammaken van een verkbestand kost nu en minder rekentijd $6 \mathbf{n}$ er kunnen in det bestand geen fouten meer voorkomen.

Over de bescherming van de persoonlijke levenssfeer is al het een en ander gezegd. Hier wil lk kort Ingaan op enkele aspecten en vooral angeven wat onze ervaringen gedurende de afgelopen faren zijn. De privacy van patienten is op verschillende wijzen gewarborgd: enerzijds en formeel furldische beveiliging welke sterk gekoppeld is an de (veronderstelde) integriteit van betrokken onderzoekers. Anderzijds zijn er enkele technische bevelligingen gekozen; zoals het 
nlet op naam registreren, maar het gebrulk maken van een warschijn11fkheidskoppeling, het coderen van de data, het loskoppelen van de privacy gevoelige data van de overige data en het niet toegankelijk voor derden maken van de data.

De formele beveiliging $11 \mathrm{gt}$ in het registerreglement en de Rad van Toezicht, warbij deze latste een visitatiecommisile heeft ingesteld. Deze visitatiecomissle heeft gedurende de afgelopen jaren diverse malen het registerteam een onverwachts bezoek Bebracht. BiJ deze bezoeken werden nooit onregelmatigheden geconstateerd, terwij1 ook intensieve checks (m.b.v. de administraties van de voorzieningen) geen dubleuze zaken an het licht brachten.

Een nadeel van het registerreglement, zoals dat door de Raad van Toezicht in samenwerking met de Dienst Juridische zaken van de RL is opgesteld en waraan de GGZ-instellingen en de RL door middel van een samenwerkingscontract hun goedkeuring hebben verleend, is dat patienten mogen welgeren dat er gegevens van hen in het MHCR worden opgenomen. Herstel: dat patiunten dat mogen is prima, mar vanuit de optiek van een onderzoeker is het vervelend dat een deel dat daadwerkelijk doet. Echter het weigerpercentage blifft ver onder de responsuitval waarmee ander onderzoek geconfronteerd wordt. Het weigerpercentage varieert per instelling: het gemiddelde 1 igt rond de $12 \%$.

In de hiernavolgende -een reeds gepubliceerd engelstalig artikelparagraaf wordt ingegaan op de (epldemiologische) mogelijkheden van het MHCR. 
THE USE OF THE CASE REGISTER IN MAKING EPIDEMIOLOGICAL RESEARCH MORE COST-EFFICIENT

M.W. DE VRIES, H. HAMERS and F. STURMANS

Departments of social piychiatry and Epldemiology, University of Ilmburg, Mastricht, the Netherlands

After World War II, as mental health services and their patient populations grew, the need to gather epidemiological and health care information became evident. Initlal studies showed that patterns of mental health care-seeking behavior were complex. Patlents differing in ethnicity and socio-economic status varied in utilization patterns; institutional services often overlapped and differed; and patients frequently used a number of institutions simultaneously (1). Data gathered by one facility were therefore inadequate for describing the health care seeking behavior in a population. To overcome this handicap, many areas established central data banks that 1 inked together divergent facilities and practices and recorded all mental health contacts in a defined population $(2,3,4)$. The modern case register was thus born, with the high expectation that it would provide a realistic plcture of psychiatric care in a population for use in planning and in making epidemiological inferences. While the function of case registers has varied, register research has clarified important thealth care issues and has been helpful. in planing $(4,5)$. More recently, researchers and health care planners have shifted their focus of attention to communitybased prevalence statistics in the population. From the comparison of these epidemiologic studies with case register data has emerged a puzzel: just what proportion of mental alsorders in a population is accounted for in the treatment prevalence statlistics of the case registers. To answer this question, prevalence figures gathered with the case register in one area have been linked with eplidemlologic studies from another area. Problematic features of these efforts, in addition to the differences In population and social context $(5,6,7)$, were that the epidemiologic surveys often did not differentiate complaints from illness, used differing research instruments and methods, and often lacked clear hypothesis to gulde the analysis of the large amounts of data collected. The relationship between case regis- 
ter and population data has therefore been difficult to determine. When specific disorders were the focus of research, and comparisons between epidemiologic findings and case register data were made within a defined population, results have proved more promising $(8,9)$.

\section{CASE REGISTER AS A. SAMPLING FRAME FOR RESEARCH}

In the linking of epidemiological approaches to register data, an attempt should be made to avoid the problem and costs of survey research by seeking clear hypothesis and dependent variables, samping specific neighbourhood locations and, where possible, using specific disorders such as the Epidemiology Catchment Area study (ECA) in the U.S. has done (10).

In Mastricht, we asked if we could use the case register in making epidemiologic research more cost-efficlent. Could the Mental Health Case Register be used as a sampling frame for research at both the population and individual level? can we control for the effect of provided health care services? can we use the MHCR to refine hypothesis to be tested in community based, case control research? Can this process illuminate case register statistics in the light of "real" prevalence rates in a population?

This broadens the use of the case register from its more traditional use as a planning device to its use in investigating potential etiological factors. This cannot be done by means of the case register findings alone because they must eventually be coupled to data gathered in the compinity; in mation, such investigations would require the inclusion of non-ill controls." We considered that the required pre-selection of ili and notill groups, as well as the selection of specific locations for community follow-up, would implicitly demand the formulation of clearer and more detailed hypotheses to be tested. This, we thought, could lead to potentialiy more efficient cohort or patient-control epidemiologic studies. One of the problems, of course, in using the case register in this way" is that "caseness" is here determined by the avalable health care and referral patterns, particularly those issuling from primary care physicians. We must therefore attempt to control for referral patterns and avallable services whin the particular subject populations. By controlling for services and by first determining 
the impact of traditional, social psychological and demographic factors, we hopie to more clearly relate the case register figures to actual population statistics, as well as creating an avenue for direct and more efficient population sampling.

\section{NEIIGHBOURHOOD STATISTICS}

specifically, as a first step, we looked at treatment prevalence statistics in each neighbourhood in Mastricht, the Netherlands. These nelghbourhoods vary on a number of soclological and demographic factors. The period prevalence figures for 1981 were chosen from the Maastricht Register. The 1981 figures tended to correlate well with incidence, generated a large sample and were reliably avallable. Our preliminary results showed that treatment prevalence figures differed remarkably between nelghbourhoods. Testing whether these neighbourhood variations could be accounted for by some standard social psychiatric hypothesis such as the influence of age and socio-economic status (SES) on utilization, we used the avaliable demographic and socio-economic data avallable in the case register and local governmental information sources and found that the number of aged in a neighbourhood did not predict utilization as expected, but that poor economic and social status did play a role as predicted.

While this is an important, but not unfamiliar, fincling to pursue, we illustrate it here only as part of a stepwise sequence of analysis and to underscore the need for the linkage of government and case register information systems lwith adequate privacy protection as necessary and useful step in clarifyling MHCR data. We must, of course, guard against the tendency toward fallacious ecological reasoning when aggregate data from varied sources are useo in such a way as here. These precautions include carefuldy monitoring the data and carrying out andyses in a number of ways in order to demonstrate that a found relationship 1 sobust, and providing a case-level analysis as we suggest later.

\section{AVATLABILITY OF MENTAL HEALTH CARE}

Demographic findings such as age, sex, marital status and sEs are often presented in population studies. We, however, wanted to take a further, and often ignored step, that of controliing for the impact of avallable health care services on 
the treatment prevalence. Starting with the hypothesis that the availability of mental health care accounts to a large extent for case register figures and perhaps more generally also for illness expression in a population, we proposed using the case register, supplemented by community sources, to derive neighbourhood samples with comparable health care services for further study. Our rational for this should be briefly justified. First, European and American studies often suggest that differences in avaldability of health care services correlates with both intramural and extramural care utilization $(6,11,12,13)$. Secondly, Goldberg (14) underlines the impact the general practitioners" mental health care referral strategies and further demonstrates that prevalence statistics differ at different levels of the health care system as a result of referral patterns. He thus documents indirectly the general contribution of the medical referral system to the care made avaliable to a population and the need to analyze speciflc primary care referral practices. Thiraly, we hold that illness arises in a social context in which the formal health care system plays a major part. Medical anthropologists have demonstrated that the health care system gives meaning and guides illness expression in a population $(15,16)$. This linkage is also particularly strong in societies. where general health insurance and highly organized health care exists, such as in modern European industrial societies. Here, the classification of physical and mental processes has markedly shifted away from the family and informal medical system to the established, professionalized medical system. Today, it may be postulated that definitions of health and patterns of health care-seeking are intimately linked with the care offered by th formal health system. In spite of this strong hypothetical injpact, the contribution of the medical system to health careseeking behavior and morbidity in a population is often ignored. we assume, on the contrary, the significance of this effect and attempt in our model to control for and hold stable the mental. health care offered a population.

DERIVING HEALTH CARE AS A VARIABLE

To control for avallable health care and derive comparative population samples we will draw on health care system, community and case register sources. First, we will define 34 neighbour- 
hoods that range in size from 1,000 to 8,000 people in the Maatricht population of 110,000 . Next, catchment area responsibilities af mental health care faclitties in these neighbourhoods w1 be ascertalned and neighbourhoods with similar spatial access to facilities will be selected, thus controlling for a atrong mediator of utilization, the distance from facilities. Further, whether the services offered a neighbourhood are similat will be tested by comparing institutional goals, manpower, avallability, size and range of services offered in each pair of faclity locations. For many services such as the larger mental hospltal, the entire case register population is included in their catchment areas, thus facliltating comparisons. We can also use the data to compare the relative use of different facilities by a neighbourhood. The case register will then be used to select neighbourhoods with similar utilization ratios of intramural and extramural services, with the aim being to determine roughly the relationship between community care-seeking patterns and avallable health care services. Soclal class, the relative use of in- and outpatient services as well as a description of available mental health care services, allow us to characterize the system and how it is used.

General practitioner referral practices, however, are more difficult to characterize and compare (14). Although we will define the number of general practitioners in a neighbourhood and the size of their practices, experience suggests that general practitioner referral strategles will vary diastically 117 . To help resolve this dilemma we wili screen out las, in fact, investigated more specificaliy in another study physicians who account for an lalosyncratic number of referrals, this will be done using case register referral figures as well as information on general practitioner referral patterns obtalned from interviews in other studies currently underway in our department. In this model, we will use multivariate techniques such as cluster analysis to link general practitioner referral behavior to other health care factors under study, producing clusters of neighbourhoocs with similar services and referral systems. These three techniques should create enough order in the referral practice of general practitioners so that the mental health care avadiable to different neighbourhoods is rendered comparable. case register care prevalence figures will then be examined 
in areas where amount and type of health care is similar. If care prevalence figures (and later incidencel vary in neighbourhoods with similar health care avallability and referral practices, specific underlying risk factors, actual morbidity, demographic and ecological factors may then be assumed to pllay a major contributory role. Specific hypothesis about the ecological relationships in that population can be formulated and be further examined using case-control and cohort approaches 115 , 19,201 .

INDIVIDUAL CASE LEVEL

Just as it is essential to control for available health care in selecting neighbourhoods with a high or low prevalence rate, it. is equaly important at the individual case level. We are, of course, assuming that individuals are comparable on the measures just outlined. The case register may be used as a sampling method, selecting cases from areas with similar mental health care as well as selecting controls from the same area using officlal community information sources. This would allow the important additional step of investigating whether commony hypothesized discriminating psychosocial factors such as live-events, economic change, moves, etc. are also at work at the individual level. We suggest that these factors are best studied in samples which have similar mental health care, demographic configurations and socio-economic status, but that differ on the prevalence of cases. To investigate these factors more closely focused field research $(7,22)$ is planned, investigating health care-seeking behavior (16), ideas about health ard disease problems $(15-20)$ as well as measures of 111 ness (21) and $r$ sk in relation to diagnosable disorder $(10)$ in the selected nelghbourhorods.

\section{DISCUSSTON}

In sum, in this model, case register and community information is used to derive small neighbourhood samples in which a control on the availability of health care services has been incorporated. These samples will be further examined with demographic variables that are guided by specific hypothesis which will in turn lead to small epidemiologic and ethnographic field research projects employing case control, cohort and historical 
(retrospective) cohort appoaches. This in turn avolds the problems and costs created by overly oroad popilation surveys and may provide a more thorough picture of actual morbidity, risk and health care-seeking behavior.

It is important to remember that regardless of how thealth care data is gathered, in populations or with a case register, the inferences drawr about the amount and type of medical care required ultimately remains a social and political question often quite divorced from actual illness data. As society changes, governments rise and fall, technology advances, and definitions of man change, the question of how much medical are is needed In a population must be continually socially asked, scientifically investigated, and politically negotiated. The case register clearly has a place in this process.

\section{REFERENCES}

1. GARDNER, E.A., MILES, H.C., BAHN, A.K. and ROMANO, J., "AII psychiatric experience in a community. A cumulatiwe survey: Report of the first year's experience" "Archives of General Psychiatry, 19, 1963, 369-378.

2. WING, L., WING, J., HAILEY, A., BAHN, A., SMITH, H. and BALDWIN, J., "The use of psychiatric services in three urban areas; an international case register study" "sociall Psuchiatry, 2, 1967, 158-166.

3. WING, J.K., and HAILEY, A., "Reported prevalence", In L. Wing and $A$. Hailey, eds., Evaluating a commuty psychiatric service. London, Oxford University Press, 1972.

4. GIEL, R. and TEN HORN, G.H.M.M., "Een pisychiatrisch register als basis voor plannung", rijeschrift voor socialle ceneskunde, 54, 1976, 148-153.

5. GARDNER, E.A. and BABIGIAN, H.M., "A longitudinal comparison of pischiatric service", American yournal of orthopsuchitut 4 . 36, 1966, 818-828.

6. GIEL, R., "The thruth about psychlatric morbidity", Acta psychiatrica scandinauica, suppl. 285, 62, 1980, 30-40.

7. HENDERSON, S. , BYRNE, D.G. and DUNCAN-JONES, P., Neurosis and the socid ervironment, Canberra, 1981.

B. HELGASON, T. "Prevalence and Incidence of mental disorders estimated by a health Questionnaire and a psychiatric Case Register" Aeta Psychiatrica Scandinavica, 58, 1978, 256-26.

9. HELGASON, "T., "The epidemlology of Alcohol Abuse", Nordisk Medielne, 99, 1984, 290-294.

10. REGIER, D.A., MYERS, J.K. KRAMER, M., ROBINS, L.N., BLAzER, D.G. "HOUGH, R.L., EATON, W.W. and LOCKE, B.2." "The NIMH Epidemiologic Catchment Area Program", Archives of General Fsychitery, 41, 1984, 934-941. 
11. REgIER, D.A., GOLDBERG, I.D. and TAUBE, C.A., The facto US mental health services system, a public health perspective", Archives of General Psychiatry. 35, 1978, 685-693.

12. LEVIN, B.L." GLASSER, J.H. and ROBERTS, R.E., "Changing patterns in Mental Health Service Coverage within Health Maintenance Organizations" "American Journal of public Health, 74, 19 , 453-458.

13. REDLICH, F. and WELLERT, S.R., "Trends in American Mental. Health", American Journal of Fsychidtry, 135, 1978, 22-28.

14. GOLDBERG, D. and HUXLEY, P., Mental illness in the communty: the pathway to psychiatric care. London, Tavistock, 1981.

15. KLEINMAN, A., Patients and healers in the context of culture. Berkeley, University of California Press, 1980.

16. DE VRIES, M.W., "Introduction: Medicalization in perspective", In M. de Vries, R.L. Berg and M. Lupkin jz, eds.. The use and abuse of medicine. New York, 1982 .

17. SHEPHERD, M. , COOPER, B., BROWN, A. and KALTON, G.W.. Psychiatric illmess in general practice. London, Oxford University Press, 1966.

18. STURMANS, F., Epldemiolagie: theorie, methoden en toepas= singen. Nijmegen, Dekker en wan de Veght, 1983.

19. FRIEDMAN, G.D. "Primer of epidemiology. New York, McGrawHi11, 1974 .

20. MACMAHON, B., PUGE, T.F., Epidemiology: princlples and methods. Boston, Little, Brown, 1970.

21. WHITING, J." "Methods and problems in cross-cultural research"" "In G. Lindzey and E. Aronson, eds. " Handbook of social psychology, Vol. 2, 2nd ed. (693-728), Reading (Mass.), Addison-Wesley, 1968 .

22. GOLDBERG, D. , Manisal of the General Health puestionnaire. Slough, National Foundation for educational research, 1979. 


\subsection{Samenvatting en conclualles}

In 1980 werd er vanult de capaciteltagroep Sociale Psychiatie een start gemakt met de opzet van een psychiatisch casus reglster voor de reglo zuldelijk zuld-Limburg met een populatie van ongeveer 200.000 inwoners. DIt register werd bekend onder de man MHCR.

De onderneming werd gesteund door het Minlaterle van Welzijn, Volksgezondheld en Cultuir, warult al blijkt dat beleldsmatige Interesse voor de ultkomsten van registerstudies aamezig vas en nog 1. Vanult de capaciteltagroep Medische Sociologle en vanult de dienst Memic werd de opzet mede begeleid.

Na een Jaar waren de betrokkenen het eens en werd een samenwerkingscontract opgesteld en ondertekend door de GGZ-voorzlenimgen en het College van Bestuur van de Rifksuniversiteit Limburg. Per 1 Januarl 1981 starten de registraties in de GGZ-instelingen: in een enkele instelling (CAD) of een onderdeel darvan (psychogeriatrische dagbehandeling van een verpleegkliniek) werd later gestart.

In dit hoofdstuk werd beschreven hoe het MHCR is opgezet, welke problemen darto overwonnen dienden te worden en hoe zowel in de Instellingen alsook t.b.v. de verwerking en de opslag van de gegevens de procedures zo zijn opgezet -en in de tijd verder verfijnd zijnwardoor optimal efficient en betrouvbar gewerkt kon worden. Darnaast heb $1 k$ ook a angegeven hoe we an de wensen inzake de bescherming van de persoonlijke levenssfeer tegemoet $z 1 j n$ gekomen en dat dit helas een negatief aspect oplevert, in de zin dat niet van ledere patidint gegevens verkregen vorden. De spanning tussen onderzoek en de wens de bescherming van de persoonlijke levenssfeer maximal te latem $21 j n$, komt hier tot uiting. Ten slotte is getoond dat een psychiatisch casus register gebruikt kan worden om epidemiologisch onderzoek gerichter op te zetten, warbij het reglister ons als het ware leldt naar mogelijke (maatschappelijke) factoren die een tiologische werking inzake psychopathologie hebben.

Afslltend moet gesteld worden dat een register een relatief kostbare investering verelst, warbij een data-base angelegd wordt die geraadpleegd kan worden voor onderzoeksvragen van uiteenlopende aard. Belangrijk is de constatering dat een psychiatrisch register nawrelifks weg te denken is in het hedendaagse (sociaal) paychiatrisch-epldemlologisch onderzoek, ordat een register onontbeerlijke gegevens levert die op een andere wifze niet of zeer moliljk te verkrijgen $21 j \mathrm{n}$. 
HOOFDSTUK 7

DE REGIONAIE GGZ

7.1 Inleiding

In dit hoofdstuk wordt een eerste empirische beschrifving van de GGZ gepresenteerd; de GGZ in een andere reglo wordt daarblj als referentie gebruikt. Het in die andere reglo gehanteerde onderzoeksinstrument is analoog an het onze, omdat het als voorbeeld gediend heeft tijdens onze opzet.

\section{2. Enkele interregionale vergelifkingen}

Zoals al in hoofdstuk 6 vermeld is, was een van de belangrijkste aanleidingen een tweede psychiatrische casus reglster in Nederland op te zetten, gelegen in het mogelijk maken van interregionale vergelijkingen. Imrers de resultaten van een reglo hebben betrekkelijk weinig warde, zowel beleldsmatig als wetenschappelijk, Indien op geen enkele wijze zicht bestaat op mogelifke generalisaties. Immers een register omvat weliswar alle of nagenoeg alle GGZ-patiénten in een regio, mar is in feite zelf een steekproef: van alle GGZ-gystemen, die in de tijd en in de ruimte aanwezig zijn, dit ene GGz-systeem hier en nu. 


\section{GGZorg gepeild}

Een vergelijkend onderzoek met behulp van twee Registers voor de Geestelijke Volksgezondheid

door F. G. Brook en H. J. F. R. Hamers

\section{Inleiding}

Alweer ruim tien iaar (sedert 31 december 1973) worden in het noordelijk Register Geesteliike Volksgezondheid alle contacten, die inwoners uit de Registergemeente $| \pm 45.000|$ hebben met voorzieningen voor de Geestelijke Gezondheidszorg (intra-, semi- en extramurale) verzameld |zie Giel en Ten Horn, 1976|. Zeven iaar later, op 31 decem. ber 1980, ging een soortgeliik Register van start voor Maastricht en omgeving $4 \pm 205.000$ inwoners $)$.

Een van de belangriikste redenen om een tweede Register op tezetten was vergelijkende studies te kunnen uitvoeren in regio"s, die duidelijk van elkaar verschillen in het aanbod van GGZ-voorzieningen. Inmiddels is een dergelijke vergeliiking mogeliik.

In deze eerste publikatie, waarin een doorsneedag (een zogenaamde 'census' ook wel puntprevalentie| wordt vergeleken, geven wij eerst een korte beschrijving van de opzet van de Registers, van de daarbii betrokken GGZ-instellingen, alsmede van enkele sociaal-demografische kenmerken van de twee regio's.

\section{Doel en kenmetken van een Register}

Niet alle registratiesystemen zijn Registers. Van een Register is pas sprake wanneer: (a) de volledige en continue registratie van de contacten van (b) de bevolking in een omschreven geografisch gebied met $|c|$ bepaalde instellingen (in dit geval de Geestelijke Gezondheidszorg) op een centraal punt gebeurt en de gegevens (d) per patiënt worden aaneengeschakeld en geordend (zie Baldwin, 1973). groep Sociale Psychiatrie vam de RU Limburg. 
Door deze volledige en continue registratie van contacten van de bevolking in een omschreven geografisch gebied met alle voorzieningen woor de Geestelijke Gezondheidszorg kunnen op betrekkelijk eenvoudige wijze statistische gegevens over de angemelde psychiatri. sche morbiditeit van de bevolking worden verkregen. Epidemiologi. sche onderzoeksvragen kunnen worden beantwoord, zoals: Om hoe. veel mensen gaat het en wat zijn globaal beschouwd hun psychiatri. sche problemen? Wat is het beloop van deze ziektebeelden?

Een Register biedt tevens mogelijkheden om kwantitatief vergelijkend onderzoek te verrichten naar planningsvraagstukken zoals over de omvang en invloed van de diverse vormen van Geestelijke Gezond. heidszorg. Door het longitudinale en continue karakter van een Regis. ter kunnen 'gaps' en 'overlaps' tussen instellingen, discontinuïteit en en dergelijke zichtbaar gemaakt en effecten van veranderingen gemeten worden.

Verder kan een Register als uitgangspunt dienen woor specifiek onderzoek. Het voordeel van het gebruik van een Register als "sampling frame' is dat men niet eerst vele vaak duizenden mensen behoeft te onderzoeken alvorens men een voldoende grote groep met het bedoelde kenmerk (b.y. een manisch-depressieve psychosel bijeen heeft.

In het buitenland, vooral in Engeland, is al jarenlang veel onderzoek met dergelijke psychiatrische Registers gedaan (zie De Graaff en Ten Horn, 1975). Wereldberoemd is, één van de eerst opgezette, het Camberwell Register, voor een deel van Londen (zie Wing and Hailey, 1972). Sinds 1980 hebben de acht UK-registers (Aberdeen, Camberwell, Car-

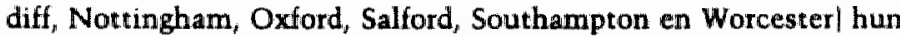
krachten gebundeld om tot gezamenlijke publikaties te komen. Zeer recent word geprobeerd een samenwerking tussen alle Registers in de wereld lincl. Europese zoals Aarhus, Dublin, Genève, Mannhein, Verona en de beide Nederlandse Registers| op gang te brengen |zie WHO workshop report, 1983 ).

Hierop voonutlopend vergelijken wij nu eerst twee Registergebie den met betrekking van de Nederlandse Registers. Deze hebben ge meen dat ze aan elke bij de GGZ aangemelde persoon afkomstig uit het Registergebied die nog niet in het Register voorkomt, een Registernummer toekennen. Alle gegevens die in de loop van de tijd wan deze personen binnenkomen worden door middel van een reeks identificatiegegevens aan de al anwezige toegewoegd (zie voot de principes Baldwin, 1973 en Wing, 1968). De gegevens die over de patiènt en over zijn contact met de GGZ in beide registers worden verzamell komen sterk overeen, alleen geven bepaalde instellingen, die bij het zuidelijke Register betrokken zijn, geen psychiatrische diagnose.

Door bet zuidelijke Registerteam worden woor bepaalde instellingen ook nog gegevens verzameld over patiën ten van buiten het Registergebied. Dit gebeurt om de betreffende instellingen een totaalbeeld over hun hulpverlening in een bepaalde periode te kunnen verschaffen. 


\section{Enkele sociaaldemografische gegevens}

Vanwege de door ons bestuurde "doorsneedag' presenteren wij hier gegevens, die betrekking hebben op het jaar 1981 .

In de eerste figuur wordt de verdeling naar geslacht, leeftijd en burgerlijke staat wergeleken van de inwoners van beide Registerregio's. De noordelijke regio telt in totaal 45.170 inwoners, de zuidelijke 204.939. De zuidelijke regio omvat dus ongeveer 4.5 keer zoveel inwoners.

De verdeling naar geslacht is vrijwel gelijk. In het zuiden zijn er meer mensen van 65 jaar en ouder, gescheidenen en mensen in de weduwstaat dan in het noorden, terwijl er in het noorden meer mensen van 0 tot $\$ 8$ jaar zijn dan in het zuiden. Al met al lijken de gebieden toch wel veel op elkaar. Maar de noordelijke regio bestaat uit slechts een gemeente, terwij] de zuidelijke naast een grote gemeente $[110.232$ inwoners| nog een elftal kleinere omvatt.

De verschillen tussen de Registerregio's zijn over het algemeen geringer dan die tussen de gemeenten van de zuidelijke regio onderling. Het bleek dat in beide regio's, vooral in het zuiden, de sterfteciffers voor mannen in alle leeftijdsgroepen hoger zijn dan voor vrouwen. Met het oplopen der leeftijd, vooral na het 45 ste levensjaar neemt de kans op sterfte sterk toe. Substantiëlle verschillen tussen beide regio's zijn echter niet waar te nemen. Samenvattend kan worden gesteld dat er tussen de populaties van de beide regio's in de door ons bestudeerde

Figuur 1: Leefrijd naar geslacht in het noorden en het zuiden

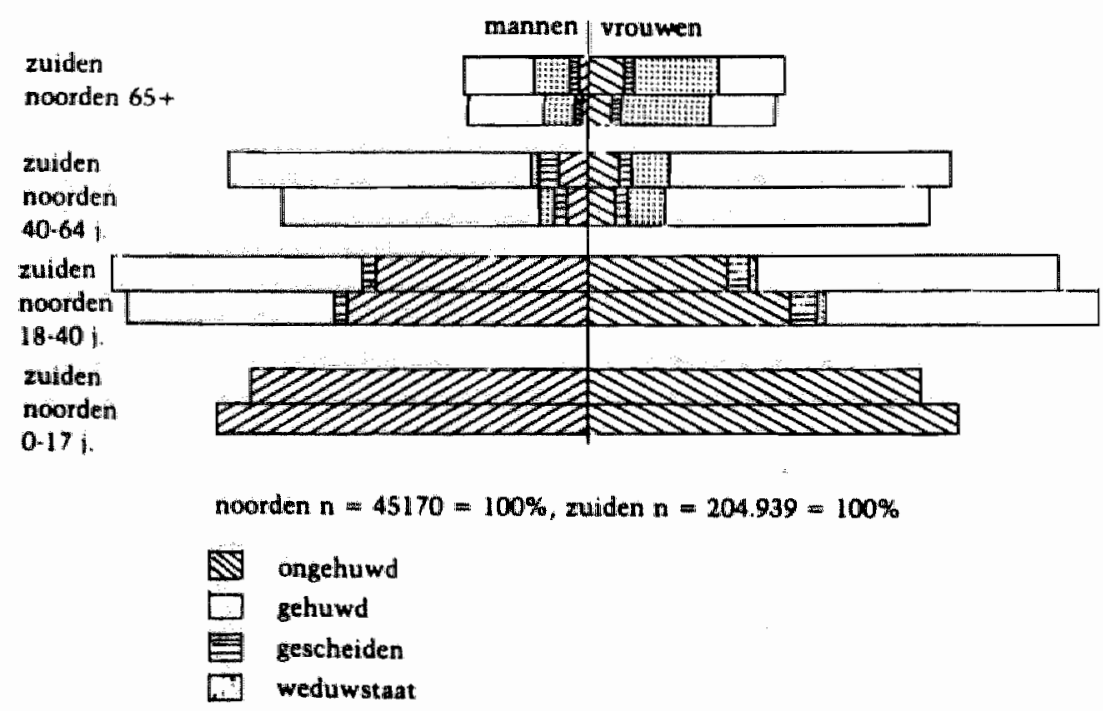


kenmerken slechts enkele verschillen kunnen worden vastgesteld. Het zuiden wordt in vergelijking met het noorden gekenmerkt door een iets kleiner aantal jeugdigen en een iets groter aantal beiaarden.

\section{De voorzieningen voor de Geestelijke Gezondheidszorg in beide Registerregio's}

Alvorens een beschriiving te geven van de instellingen die betrokken ziin bii de beide Registers, moet worden opgemerkt dat het in dit onderzoek uitsluitend gaat om de contacten die inwoners uit het Registergebied hebben met GGZ-instellingen. Het aandeel van inwo* ners uit het Registergebied in het totaal van de clièntèle kan per

Tabel I: De GGZ vaorzieningen in de noordelijke en zuidelijke regio anno 1981

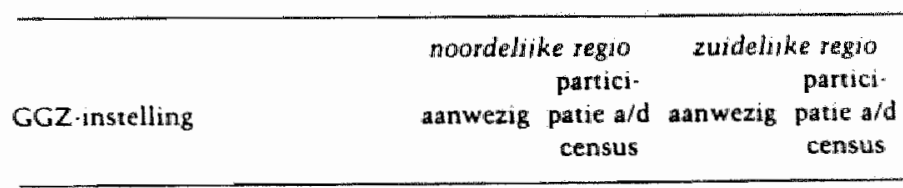

\section{Intramuraal}

Alg. Psych. Ziekenhuis

Psych. Afd. Alg. Ziekenhuis

Verslavinuskliniek

Inst. $v$. Kinderpsychiatrie

Psychogeriatr. Verplih.

Zwakzinnigeninstituut

Kliniek voor TBR

semumuraal

Medisch Kleuterdagverbl.

Medisch Kindertehuis

Dagzickenhuis APZ

Dagbchand. Psychogeriatrie

Beschermende woonvormen

"Crisisopvangcentrum"

extramuraal

polikl. Alg. Psych. Ziekenthuis

pollikl. Psych. Afd. Alg. Ziekenh

poli-Kinderpsychiatrie

Consultatiebureau Alc en Drugs

Inst. Multidisc. Psychotherapie

Regional Inst Amb Ceeste-

liike Gezondheidszorg

Vriigevestigde zenuwartsen

24-uurs opvangpost

Socialal Pedagog. Dienst

\begin{tabular}{|c|c|c|}
\hline$x$ & $\mathrm{x}$ & $x$ \\
\hline$x$ & $x$ & $x$ \\
\hline $\mathrm{x}$ & $\mathbf{x}$ & \\
\hline $\mathbf{x}$ & $x$ & \\
\hline$X$ & $\mathrm{X}$ & $x$ \\
\hline $\mathrm{X}$ & $x$ & $x$ \\
\hline$X$ & $\mathrm{x}$ & \\
\hline
\end{tabular}

$x$

$x$

$\mathrm{x}$

$x$

$x$

$x$

$X$

$x$

$\mathrm{x} \quad \mathrm{x}$

$x \quad x$

$\mathrm{x}$

$\mathrm{X}$

$\mathbf{x}$

$\mathrm{x}$

$\mathrm{x}$

$\mathrm{x}$

\begin{tabular}{|c|c|c|c|}
\hline$x$ & $x$ & $x$ & $x$ \\
\hline$x$ & $\mathbf{x}$ & $x$ & $\mathrm{X}$ \\
\hline $\mathrm{X}$ & $\mathrm{x}$ & & \\
\hline$X$ & $x$ & $x$ & \\
\hline$x$ & $x$ & $x$ & $x$ \\
\hline \multirow[t]{3}{*}{$x$} & $x$ & $x$ & $x$ \\
\hline & & $x$ & $x$ \\
\hline & & $\mathrm{x}$ & $\mathbf{x}$ \\
\hline $\mathbf{x}$ & & $x$ & $x$ \\
\hline
\end{tabular}


instelling sterk varièren, maar is nooit $100 \%$ omdar geen enkelle instelling zich uitsluitend richt op de inwoners uit het Registergebied.

In tabel 1 staan de voor de beide Registerregio's beschilkbare GGZ. woorzieningen en wordt vermeld of de instelling ook betrokken was bij de zogenaamde censustelling.

Niet alle intramurale voorzieningen die in de noordelijke Registerregio aanwezig zijn, zijn ook in de zuidelijke Registerregio aanwezig. Zo ontbreken in het zuiden een instituut voor kinderpsychiatrie, een TBR-kliniek en een verslavingskliniek. De instituten voor de zwakzinnigenzorg ziin in het zuiden weliswaar aanwezig maar ontbreken in de zogenaamde censustelling. Ook is psychogeriatrische dagbehandeling in het zuiden wel aanwezig maar voor de censustelling niet verzameld. In het noorden is bij de Psychiatrische Universiteitskliniek te Groningen (dus buiten de Registerregiol een crisisopvangcentrum beschikbaar en ook bij de censustelling meegenomen als het om patiënten wit de Registergemeente gaat.

In het noorden is in de Registergemeente geen crisisopvangcentrum beschikbaar, terwijl dit in het zuiden wel het geval is. In het zuiden participeren in tegenstelling tot het noorden een Medisch Kleuterdagverbliff en een Medisch Kindertehuis aan het Register. Verder is er voor het gemak in het noorden geen onderscheid gemaakt tussen de verschillende afdelingen van het Algemeen Psychiatrisch Ziekenhuis, hoewel bepaalde afdelingen zich duidelijk richten op een psychiatrische semimurale behamdeling.

Extramuraal zijn er nog duidelijkere verschillen in "iet aanbod aan voorzieningen in beide regio's. Zo is het opvallend dit in tegenstelling. tot het zuiden er in het noorden geen vrijgevestigde zenuwartsen beschikbaar zijn en dat het Consultatiebureau voor Alcohol en Drugs in het zuiden weliswaar beschikbaar is maar in 1981 nog niet participeert in het Register.

Het Instituut voor Multidisciplinaire Psychotherapie (IMP) is in beide regio's beschikbaar en participeert ook in de beide Registers.

In deze analyse zal het IMP verder worden meegerekend tot het Regionale Instituut voor de Ambulante Geestelijke Gezondheidszorg. Het RLAGG in het zuiden omvat naast vier rayonteams en het IMP nog een drietal centrale teams te wreten, het team Langdurende en Structurele Begeleiding [LSB-team), het geriatrische team en het team Kinderen Jeugdzarg $[\mathrm{KJ} / \mathrm{Z}$ ).

Een deel van de werkzaamheden van het al eerder genoemde KOC in het zuiden is ambulant en als zodanig in het onderzoek verwerkt onder '24-uurs opvangpost'. De sociaal pedagogische dienst is mede in verband met de participatie van het Medisch Kleuterdagverblijf en het Medisch Kindertehuis in het zuiden betrokken bil het Register. De sociaal-pedagogische dienst is daar namelijk de instantie die de verwijzing naar de semimurale voorzieningen verzorgt.

Samenvattend kunnen we stellen dat met betrekking tot de ouderen 
in de beide regio's dezelfde soort en voorzieningen aanwezig ziin en participeren aan de zogenaamde censustelling (met uitzondering van de psychogeriatrische dagbehandeling in het zuiden/. Met betrekking tot de volwassenen moet worden opgemerkt dat er geen vrigevestigde zenuwartsen in het noorden ziin. Van alle anwezige extramurale voorzieningen ontbreekt in het zuiden alleen het $\mathrm{CAD}$ an de censustelling.

Met betrekking tot kinderen hebben de beide regio's een duidelijk verschillend pakket aan voorzieningen. Intramurale instituten woor kinderpsychiatrie ontbreken in het zuiden, en omdat men het idee heeft dat deze functie voor een deel wordt ingevuld door het Medisch Kleuterdagverblijf en ' Medisch Kindertehuis zijn beide laatste in tegenstelling tot het noordelijk Register van bet begin bij het Register betrokken.

\section{Een doorsneedag}

In navolging van de definiëring van Camberwell (zie Wing, 1972) worden in de census opgenomen, c.q. op een doorsneedag geteld:

1. Alle patiënten die op die dag (de zgn. peildatum/ worden of zijn opgenomen in één der intramurale instellingen, uitgezonderd degenen die op die dag worden ontslagen, en alle patiënten die op de peildatum in een semimurale voorziening wonen of die bezoeken

2. Alle patiënten die zowel vóór als na de peildatum een ambulant contact met een GGZ-instelling hebben met een maximale tussenperiode van drie maanden;

3. Alle patiënten die omstreeks de peildatum overgaan van de ene GGZ-instelling naar een andere |bijv. van intramuraal naar extramuraal/ mits de periode tussen het contact met de twee instanties niet meer dan drie maanden bedraagt. Met onderstaand voorbeeld zal worden toegelicht wie wel en wie niet in de census werd opgenomen:

-A heeft een ambulant contact op 10 januarien op 6 april 1981 . Omdat de tussenliggende periode minder is dan drie maanden wordt A dus in de census opgenomen.

-B wordt op 7 februari ontslagen wit een psychiatrisch ziekenhuis en heeft een ambulant contact op 3 juni 1981. De tussentiggende periode is niet ${ }^{1}$ langer dan drie maanden wardoor $B$ njet in de census wordt opgenomen.

Figuur 2: Censuscriteria

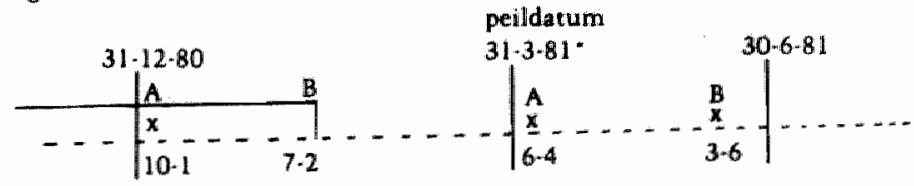


In tabel 2 presenteren wil per instelling het aantal patiënten per 1000 van de bevolking in beide Registerregio"s.

Met "eerste instelling' bedoelen wij dat iemand tijdens de periode van 1 januari 1981 tot en met 30 juni 1981 een van deze instellingen als eerste inistelling heeft.

Uit tabel 2 blijkt dat op een willekeurige dag in het noorden 9.59 personien per 1000 van de bevolking in contact waren met de GGZ, in het zuiden was dit 9.76 per 1000 van de desbetreffende bevollking. Wanneer we de instellingen die in de beide regio's voorkwamen maar in éen van beide regio's niet meededen aan de zogenaamde censustel. ling, buiten deze vergelijking laten, dan worden deze aantallen voor het noorden en bet zuiden respectievelijk 7.59 en 8.13 per 1000 van de desbetreffende bevolking.

Uit tabel 2 blịkt dat andere intramurale voorzieningen dan de PAAZ

Tabe/2: De censuspatienten op de doorsneedag in de CGZ-instellingen in de noordelijke en zuidelijke regio in absolute atatallen, percentages en per 1000 van de bevolking

\begin{tabular}{|c|c|c|c|c|}
\hline & \multicolumn{4}{|c|}{$\begin{array}{l}\text { eerste instelling periode } 1-1 / 30-6.81 \\
\text { moorden } \\
\text { zuiden }\end{array}$} \\
\hline & abs. & $\psi_{0}$ & abs. & $\%_{0}$ \\
\hline \multicolumn{5}{|l|}{ intramuraal } \\
\hline Alg. Psych. Ziekenhuis & 48 & 1.06 & 197 & 0.96 \\
\hline Psych. Afd. Alg. Ziekenh. & 10 & 0.22 & 19 & 0.09 \\
\hline $\begin{array}{l}\text { andere intramurale } \\
\text { voorzieningen }\end{array}$ & $83 *$ & 1.84 & $154^{\cdots} \cdots$ & 0.75 \\
\hline \multicolumn{5}{|l|}{ semimuraal } \\
\hline $\begin{array}{l}\text { Medisch Kleuterdagverblif" } \\
\text { Medisch Kindertehuis" } \\
\text { Dagziekenhuis" }\end{array}$ & - & - & 93 & 0.45 \\
\hline Pensiontehuis & 7 & 0.15 & $39 \cdots \cdots$ & 0.19 \\
\hline \multicolumn{5}{|l|}{ Dagbeh. Psychogeriatrie* } \\
\hline Crisisopvangcentrum & - & - & 5 & 0.02 \\
\hline \multicolumn{5}{|l|}{ extramuraal } \\
\hline poli-APZ & 80 & 1.77 & 186 & 0.91 \\
\hline poli-PAAZ & 4 & 0.09 & 167 & 0.81 \\
\hline RIAGG [incl. LMP] & 176 & 3.90 & 779 & 3.80 \\
\hline$C A D^{*}$ & 29 & 0.64 & - & - \\
\hline vriigevest. zenuwartsen & - & - & 92 & 0.45 \\
\hline 24-uurs opvangposit & - & - & 29 & 0.14 \\
\hline Soc. Pedag Dienst* & - & - & 240 & 1.17 \\
\hline Totalal & 433 & 9.59 & 2000 & 9.76 \\
\hline
\end{tabular}

- Deze instellingen worden niet in de verdere analyse betrokken. 
N.B.: onder andere intramurale voorzieningen wordt verstaan: Psychogeriatrisch verpleegtehuis, $z$ wakzinnigeninstituten, instituten voor kinderps ychia trie, verslavingsklinieken en TBR-kliniek

Tabel $2 a$ : Het aantal censuspatienten dat als eerste instelling een intra -, semil-, of extramurale voorziening had in absolute aantallen en per 1000 van de bevol. king (exclusief de instellingen die in beide regio's voorkwamen natar in eén van beide regio's (nog) niet betrokken waren bij een register)

\begin{tabular}{lrlrr}
\hline & \multicolumn{2}{c}{ noorden } & \multicolumn{2}{c}{ zuiden } \\
& abs. & \%o & abs. & $\%$ \\
intramuraal & 79 & 1.75 & 370 & 1.81 \\
semimuraal & 4 & 0.09 & 44 & 0.21 \\
extramuraal & 260 & 5.76 & 1253 & 6.11 \\
Totaal & 343 & 7.59 & 1667 & 8.13 \\
\hline
\end{tabular}

-. waarvan 16 in een psychogeriatrisch verpleeghuis, d.w.z. $0.35 \%$

... uitsluitend psychogeriatrisch verpleeghuis

*.. uitsluitend beschermende woonvormen

en het APZ als "eerste instelling" meer in het noorden voork wamen dan in het zuiden. Dit is te verklaren door de participatie in het noorden van de $z$ wakzinnigeninstituten aan de zogenaamde census en de aanwezig. heid van de verslavingskliniek, TBR-kliniek en het instituut voor kinderpsychiatrie.

Uit tabel 2 a blijkt dat de aantallen opgenomen personen in de zuidelijke en noordelijke regio bijna gelijk zijn, respectievelijk $1.75 \mathrm{en}$ $1.81 \%$. In het noorden werden echtex meer mensen op de PAAZ opge. nomen dan in thet zuiden, respectievelik 0.22 en $0.09 \%$, terwill in het zuiden meer personen in het psychogeriatrisch verpleeghuis worden opgenomen dan in het noorden, respectievelijk 0.75 en $0.35 \%$

Uit tabel 2 a bliikt eveneens dat in het zuiden per 1000 van de bevol. king meer semimuraal contact is dan in het noorden, respectievelijk 0.21 en $0.09 \%$. Hierbij dient te worden opgemerkt dat in het noorden een deel van de semimurale sector onder het APZ viel. Per 1000 van de desbetreffende bevolking is in het zuiden de extramurale sector groter dan in het noorden, respectievelijk 6.11 en $5.76 \%$. Uit tabel 2 blikt dat dit verschil komt door de aanwezigheid van de vrijgevestigde zenuw artsen en de 24-uurs opvangpost namelijk 0.45 en $0.14 \%$. Het aandeel van de poll-APZ en de poli PAAZ te zamen is in beide gebieden bijna even groot, namelijk in het moorden $1.86 \%$ en in het zuiden 1.72, maar vertoont een totaal andere samenstelling. In het noorden is het aandeel van de poli-APZ bijna twee keer zo groot als in het zuiden, respectieve lijk 1.77 en $0.91 \%$, en het aandeel van de poli-PAAZ in het noorden beduidend minder dan in het zuiden, respectievellijk 0.09 en $0.81 \%$

Het aandeel van de RIAGG is in beide gebieden wat betreft de extramurale sector verreweg het grootst en in beide gebieden ongeveer 
geliuk, respectievelijk in het noorden $3.90 \mathrm{en}$ in het zuiden $3.80 \%$.

Om de vergeliikbaarheid van beide gebieden te vergroten zullen wij in het nu volgende die instellingen buiten de analyse laten die weliswaar in beide gebieden voorkomen, maar in éến van beide gebieden niet betrokken zijn bij de zogenaamde censustelling. Wij gaan er namelijk wan uit dat de functie van de instellingen die niet in én van beide gebieden voorkomen door andere instellingen wordt vervuld. In het noorden zal bijvoorbeeld de functie van de vrijgevestigde zenuwartsen worden vervuld door de RIAGG en de poliklinieken wan de PAAZ en het APZ. Tabel 3 geeft de aantallen personen in zorg weer volgens de eerder genoemde censuscriteria.

Tabel 3: De censuspatiènten in het noorden en in het zuiden in percentages en per 1000 wan de betreffende bevolking naar soort zorg op de censusdag*

\begin{tabular}{|c|c|c|c|c|}
\hline \multirow[b]{2}{*}{ soort zorg } & \multicolumn{2}{|c|}{ moorden } & \multicolumn{2}{|c|}{ zuiden } \\
\hline & $\%$ & 加 & $\%$ & $\%$ \\
\hline alleen extramuraal & 70 & 5.29 & 70 & 5.72 \\
\hline alleen intramuraal & 19 & 1.44 & 22 & 1.81 \\
\hline combinatie & 11 & 0.86 & 7 & 0.60 \\
\hline Totaal. & $\begin{array}{l}100 \\
n=343\end{array}$ & 7.59 & $\begin{array}{l}100 \\
n=1\end{array}$ & 8.13 \\
\hline
\end{tabular}

* zie pagina 120

Extramuraal is zowel in het noorden als in het zuiden procentueel de grootste categorie, namelijk $70 \%$, gevolgd door intramuraal $\mid \pm 20 \%$ ) en de combinatie van zowel intra-, semi- als extramuralle zorg.

In tabel 4 wordt het aantal instellingen weergegeven waarmee men tiijens de censusperiode in contact komt.

In het noorden zijn 52 personen $15.2 \%$ in een periode van een half jaar met meer dan eén instelling in contact geweest, in het zuiden is dit $14.2 \%(236)$.

Tabel 4 : Het aantal instellingen in het noorden en in het zuiden warmee men tussem 1-1-1981 en 30-6-1981 in contact kwam

\begin{tabular}{|c|c|c|c|c|}
\hline \multirow{2}{*}{$\begin{array}{l}\text { antal } \\
\text { instellingen }\end{array}$} & \multicolumn{2}{|c|}{ moorden } & \multicolumn{2}{|c|}{ zuiden } \\
\hline & abs. & $\%$ & abs. & $\%$ \\
\hline eén & 291 & 84.8 & 1431 & 85.8 \\
\hline twee & 43 & 12.57 & 160 & 9.67 \\
\hline drie of meer & 9 & $2.6^{15.2}$ & 76 & 4.6 \\
\hline Total & 343 & 100 & 1667 & 100 \\
\hline
\end{tabular}


Als personen tijdens de censusperiode bij meer instellingen komen. is het nuttig te weten met welk soort voorzieningen men in contact is geweest.

In tabel 5 worden een aantal combinaties weergegeven: de groep "anderszins' omvat zowel andere dan vermelde combinaties tussen twee instellingen alsook combinaties waarbij drie of meer instellingen zijn betrokken.

Tabel 5: Soort zorg in de periode 1-1-1981 en 30-6-1981

\begin{tabular}{lrrrr}
\hline \multirow{2}{*}{ soort zorg } & \multicolumn{3}{c}{ noorden } & \multicolumn{2}{c}{ zuidien } \\
\hline extra & 228 & 67.1 & 1066 & 63.9 \\
semi & 2 & 0.6 & 3.5 & 2.1 \\
intra & 61 & 17.8 & 330 & 19.8 \\
extra-extra & 7 & 1.5 & 9.6 & 5.8 \\
extra-intra & 12 & 3.5 & 39 & 2.3 \\
intra-intra & 5 & 1.5 & 6 & 0.4 \\
anderszins & 28 & 8.2 & 95 & 5.7 \\
& & & & \\
Totaal & 343 & 100 & 1667 & 100 \\
\hline
\end{tabular}

Uit tabel 5 blijkt dat de categorie extramurale zorg in beide gebieden de belangrijkste soort van zorg is, respectievelijk in het noorden $67.1 \%$ en in het zuiden $63.9 \%$. De categorie semimuraal was in beide gebieden klein, respectievelijk in het noorden $0.6 \%$ en in het zuiden $2.1 \%$. In beide gebieden ziin tussen 1-1-1981 en 30-6-81 procentueel ongeveer evenveel personen opgenomen respectievelijk in het noorden $17.8 \%$ en in het zuiden $19.8 \%$.

De categorie 'extramuraal naar extramuraal' laat procentueel een duideliik verschil zien tussen beide gebieden. In het zuiden gaan meer personen van een extramurale voorziening naar een andere extramurale voorziening dan in het noorden: hierbij dient vermeld te worden dat in het zuiden 38 RIAGG-cliënten voor hun behandeling overgingen van een rayonteam - de eerste lijn binnen het RIAGG - naar een centraal team. Tenslotte willen wij enkele persoonskenmerken in de verschillende censustellingen presenteren.

In tabel 6 wordt de leeftijdsverdeling voor mannen en vrouwen weergegewen die bij de censustelling waren betrokken, in absolute aantallen en per 1000 van de betreffende bevolkingscategorie.

Uit tabel 6 blijkt dat in het noorden per 1000 van de desbetreffende bevolking zowel voor mannen als vrouwen beduidend meex jongeren in contact zijn met de GGZ dan in het zuiden, respectieveliik $5.80 \%$ in het noorden versus $0.88 \%$ in het zuiden. De leeftijdscategorie 18.40 is voor beide geslachten in beide gebieden ongeveer gelilk, maar de cate. gorie 41-64 is voor beide geslachten in het zuiden beduidend hoger dan 
Tobel 6: De censuspopulatie nar leeftijd en geslacht ${ }^{*}$ in het noorden en bet zuider in absolute antallen en per 1000 van de betreffende bevolking

\begin{tabular}{|c|c|c|c|c|c|c|c|c|}
\hline \multirow[b]{2}{*}{ leeftiod } & \multicolumn{4}{|c|}{ noorden } & \multicolumn{4}{|c|}{ zuiden } \\
\hline & $\begin{array}{r}M \\
\text { abs. }\end{array}$ & $\%$ & $\begin{array}{c}V \\
a b s\end{array}$ & $\%$ & $\begin{array}{c}\mathrm{M} \\
\text { abs. }\end{array}$ & tho & $\begin{array}{c}\mathrm{V} \\
\text { abs. }\end{array}$ & Tou \\
\hline $0-17$ & 40 & 6.49 & 35 & 5.80 & 23 & 0.88 & 22 & 0.88 \\
\hline $18-40$ & 62 & 7.50 & 74 & 8.67 & 277 & 7.22 & 349 & 9.62 \\
\hline 4164 & 30 & 5.71 & 34 & 5.95 & 280 & 10.28 & 330 & 11.94 \\
\hline 65 e.o. & 19 & 9.17 & 49 & 15.62 & 114 & 11.65 & 265 & 18.28 \\
\hline Totaal & 151 & 6.94 & 192 & 8.20 & 694 & 6.83 & 966 & 9.35 \\
\hline
\end{tabular}

- Van 7 personen in het zuiden was het geslacht onbekend

in het noorden, respectievelijk $\pm 11.00 \%$ in het zuiden versus $5.80 \%$ in het noorden. De leeftijdscategorie 65 jaar en ouder is in het zuiden zowel voor mannen als vrouwen biina $3.00 \%$ meer dan in het noorden; in beide gebieden echter is dit zowel voor mannen als vrouwen de grootste categorie.

De belangrijkste overeenkomsten in dit eerste vergelijkende onderzoek met twee Registers voor de Geestelijke Gezondheidszorg kunnen als volgt worden samengevat:

- het aantal personen in zorg per 1000 wan de desbetreffende bevolking is in beide gebieden ongeveer gelijk,

- in beide gebieden is het percentage cliënten dat met meer instellingen in contact komt groot,

- het RIAGG heeft in beide regio's een groot aandeel aan de verleende zorgi

- de semimurale zorg is in beide gebieden gering.

Als belangripkste verschillen noemen wij de volgende:

- de polikliniek van het APZ in het moorden beeft een groter aandeel aan de totale verleende zorg dan dezelfde voorziening in het zuiden, terwiil voor de pollikliniek van de PAAZ het omgekeerde geldt;

- in het noorden is de leeftijdsgroep van 0-17 jaar aanzienlijk groter dan in het zuiden.

\section{Discussie}

De hier gepresenteerde informatic verkregen vanuit twee Registers voor de Geestelijke Gezondheidszorg laten duidelijke verschillen en overeenkomsten zien tussen twee regio's.

Wellicht zijn de overeenkomsten frappanter dan de versichillen temeer indien men bedenkt dat de structuur van de GGZorg in beide regio's duidelijke verschillen vertoont. Immers bet zuiden kent enkele 
praktiiken van vrijgevestigde zenuwartsen en vooral de polikliniek van de PAAZ heeft in thet zuiden een omvangrijke clientèle. Daamaast is nog vam belang om te vermelden dat het RLAG in het zuiden al genuime tijd /vanaf 1977) functioneert als en multifunctioncle AGGZ-instelling warbij van de vroegere organisatiestructuur met afzonderlijke bureaus (SPGD, LGV, MOB, SPD) nog mat weinig is terug te vinden.

Een belangrijk verschil tussen beide censuspopulaties is gelegen in de leeftijdsopbouw. Met name blijkt dat in het noorden meer jongeren |0-17 jaar| in contact staan mer de GGZorg-instellingen. Dit is vriwel geheel te verklaren uit het gegeven dat het RLAGG in het zuiden naar verhouding veel minder jongerem ziet dan het noordelijke RIAGG [LGV, SPD, SPGD, IMP en MOB te zamen]. Een deel van de behandeling van kinderen vindt bij bet zuidelijke RIAGG plaats binnen de zogenaamde rayonteams - de 'eerste lijn' binnen het RIAGG - terwiil pas indien specifieke behandelingsvormen gewenst zijn ex een interne doorverwijizing plaatsvindt naar het centrale team Kinder-en Jeugdzorg. Ingang bij het rayonteam van een 'opvoedingsprobleem' kan echter - al dan niet terecht - vertaald worden naar een probleem van de ouder|s\}en de ouder $|s|$ wordt ingeschrever als client. Uiteraard zal dit niet altijd gebeuren, maar wellicht is het een deel van de verklaring hoe de gekozen organisatievorm consequenties heeft voor de wije wie geholpen wordt en dus ook voor de daanuit gedestilleerde informatie.

Een waarschuwing is dus op zijn plaats. Men moet bedenken dat de gepresenteerde informatie eerder een weerspiegeling is van het aanbod en de structuur van de voorzieningen dan van de behoefte aan voorzie. ningen (zie Van Weerden-Dijkstra en Giel, 1974). Zo kan men wit de bevinding dat er in het zuiden meer semi murale zorg voork wam dan in het noorden niet concluderen dat er in het noorden minder behoefte is aan semimurale zorg. Echter wel dat er in het zuiden meer semimurale zorg beschikbaar was dan in het noorden. De behoefte van de bevolking aan voorzieningen kunnen wij niet met prevalencecijfers meteh.

De behoefte van een bevolking is warschijnlijk sterk variabel en afhankelijk van de introductie van voorzieningen en wan hun veronderstelde of bewezen succes. En daar het aannemelijk is dat het soort stoomissen in de twee vergeleken populaties niet sterk verschill, zijn de hier gepresenteerde gegevens vermoedelijk voomameliik een weerspiegeling van het aambod aan voorzieningen. Een veelwuldig gestelde vraag of twee regionale Registers voldoende zijn om het landeliikte beleid van informatie te voorzien moet dan ook ontkennend worden bean twoord. In elk gebied war een samenhangend geheel van voorzie ningen in de toekomst aanwezigzal zijn, bijwoorbeeld op provinciaal of op RIAGG-niweau, zal een register een uitstekende informatiebron zijn voor de planning en het beleid ten aanzien van Geestelijke Gezond heidszorgvoorzieningen en de evaluatie daarvan. Elk registratiesysteem toont namelijk uitsluitend het aanbod van voorzieningen aan en 
wat er birninen de voorzieningen platatsvindt. En elk gebied zal mede door het autonome beleidskader een versichillend aanbod aan voorzieningen hebben.

\section{Literatuux}

Baldwim, J. A. (1973), Linked record medical informationsystems: Proc. R. Soc. Lond B. 184, 403.

Giel, R. en G. H. M. M. ten Horn (1976), Een psychiatrisch register als basis voor planning. T. w. Soc Geneeskunde 54, 148.

Graaf $A . C$. de, en C. H. M. M. ten Horn [1975], Psychiatrische patiëntregisters in Engeland, Denemarken en Nederland anno 1975. T. v. Soc. Geneeskunde 53,829 .

Weerden-Dijkstra, I. R. van, en R. Giel (1974), Mededelingen uit het Centrale: Patiënten-Register voor psychiatrische ziekenhuizen en universiteitsklinieken. Tijdschrift voor Psychiatrie 16, 453.

Wing, L, a . o. 1968/, Camberwell Cumulative Psychiatric Case Register. Part I Aims and Methods, Soc. Psychiotry $3,116$.

Wing, J. K., and A. Hailey (1972), Evaluating a community psychioutic service: Camberwell Register 1961-1971. Oxford Press, Oxford.

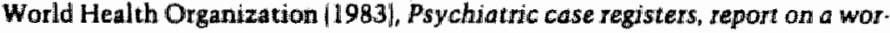
king group. Mannheim 5-6 may.

F. G. Brook en H. J. F. R. Hamers

The treated 'onc-day prevalence' of mental Illness: a comparative study with two mental health case registers.

'One-day prevalence' figures from the two Dutch psychiatric case-registers have been compared. Findings suggest remarkable similarities. In both areas most people contacted out -patient services, especially the so called Regional Institutes for Ambulatory Mental Health Care IRIAGGil.

The age distribution of registered patients differed in both areas; in the north considerably more children were in care than in the south. 


\title{
De GGZ in het noorden en het zuiden des lands in 1981
}

\author{
door H.J.F.R. Hamers en F.G. Brook
}

\section{Samenvatting}

De jaarprevalentiecijfers van twee Nederlandse poychiatrische case-registers zijn wergeleken en hoewel de resultaten in grote lijn enkele opmerkelijke overeenkomsten te zien geven, blijken er daamanst duidelijke verschillen tussen de GGZ in beide regio's aanwezig te zijn.

In het al gemeen konden wij de resultaten van onze cerste vergelijkende studie - gebaseerd op een puntprewalentietelling in beide regio's - repliceren. In beide regio's $\mathrm{kwamen}$ de meeste patiènten in contact met ambulant werkende voorzieningen; dat gold in het bijzonder voor de RLAGG.

De diagnostische verdeling gaf enkele verschillen te zien voor de opgenomen patiëntenpopulatie.

\section{Inleiding}

Sinds kort is het in Nederland mogelijk vergelijkende studies uit te voeren met behulp van twee regionale registers voor de geesteliike gezondheidszorg. De eerste studie betrof een vergelijking tussen beide gebieden op een tijdstip, de zogenaamde puntprevalentie |zie Brook en Hamers 1985/. Een van de belangrijkste conclusies was, dat de gepresenteerde informatie voomamelijk een afspiegeling is van het aanbod an voorzieningen in de twee registergebieden.

Hier wordt verslag gedaan van een tweede vergelijking waanin de onderzoekspopulatie wordt gevormd door alle personen die in 1981 met é́n of meer woorzieningen voor de geestelijke gezondheidszorg (GGZ) contact hadden en woonachtig waren in én van beide register * gebieden (een zogenaamde jarprevalentievergelijking).

Alvorens dat te doen geven wij eerst een korte beschrijving van de beide registers en de voornaiamste overeenkomsten en verschillen zoals die uit de eerste publikatie naar voren kwamen. Voor een meer gedetailleerde beschniving van de bij de registers betrokken voorzie. ningen verwijzen wij naar onze eerste gezamenlijke publikatie. 


\section{Debeide registers}

Beide onderzoeksinstrumenten zijn opgezet naar analogie van het Camberwell Register (Wing anci Hailey 1972). Voor beide registers geldt dat de volledige en continue registratie van de bevolking, woonachtig in een omschreven geografisch gebied en in contact met de GGZ, op een central punt wordt bijeengebracht en dat de gegevens per patjënt worden aaneengekoppeld en geordend.

Dit aaneenkoppelen geschiedt middels een waarschijnlijkheidskoppeling (Baldwin 1973), die erop gebaseerd is dat van iedere persoon een aantal unieke gegevens wordt verzameld en vervolgens aan iedere persoon een uniek registernummer wordt toegekend. De doelen van beide registers zijn dezelfde: namelijk het beantwoorden van epidemiologische onderzoeksvragen en vragen ten aanzien van de planning van de GGZ. Registers worden bovendien als bron voor meer specifieke onderzoekingen gebruikt (Hoek e.a. 1984 en De Vries en Hamers 1984).

De verschillen tussen beide registers komen voomamelijk voort uit het gegeven dat in de structuur van de GGZ in de twee gebieden duidelijke verschillen zijn waar te nemen en dat de omvang van de populatie in het zuidelijk registergebied ongeveer 4,5 keer 20 groot is als die van het noordelijk registergebied. De aanpak rond de bescherming van de persoonlijke levenssfeer geeft ook enkele verschillen te zien (Hamers 1984). Deze verschillen komen voornamelijk woort uit het feit dat beide registers op een ander tijdstip /het noordelijk register in 1973 en het zuidelijk in 19801 zijn geinitieerd; in 1980 bleek het noodzakelijk de procedures angaande de bescherming van de persoonlijke levenssfeer - waaronder de wijze waarop de patiënt geünformeerd dient te worden-zeer strak en geformaliseerd vast te leggen. Een van de consequenties daarvan is, dat er in het zuiden meer patiënten zijn, die weigeren dat er van hen gegevens worden opgeslagen. Het gemmiddelde percentage weigeraars in bet zuiden ligt op ongeveer $7 \%$, terwill het percentage in het noorden te verwairlozen is.

\section{DeGGZ in beide registergebieden}

In tabel 1 is opgenomen welke voorzieningen in de twee registergebieden aanwezig zijn, tevens is aangegeven welke van de genoemde vooraeningen aan deze vergelijkende studie geparticipeerd hebben. Voor een meer uitgebreide beschrijving van de voorzieningen verwijzen wij naair onze eerste gezamenlijke publikatie.

De belangrijkste resultaten van de eerste studie, een puntprevalentietelling werden als volgt samengevat:

- het antal personen in zorg per 1000 van de desbetreffende bevol. king is in beide gebieden ongeveer gelijk;

- in beide gebieden is het percentage cliënten dat met meer instellingen in contact komt groot; 
Tabel 1: De GGZ·voorzieningen in het zuideli|ke en noordelijke registergebied

\begin{tabular}{|c|c|c|c|c|}
\hline & \multicolumn{2}{|c|}{ Noordelijike gebied } & \multicolumn{2}{|c|}{ Zuidelike gebied } \\
\hline & $\begin{array}{l}\text { Aan- } \\
\text { wezig }\end{array}$ & $\begin{array}{l}\text { Participa- } \\
\text { tie aan } \\
\text { deze scudie }\end{array}$ & $\begin{array}{l}\text { Aan - } \\
\text { wezig }\end{array}$ & $\begin{array}{l}\text { Participa. } \\
\text { tie an } \\
\text { deze studie }\end{array}$ \\
\hline \multicolumn{5}{|l|}{ Intramurasl } \\
\hline$A P Z$ & $x$ & $\mathbf{x}$ & $\mathbf{x}$ & $x$ \\
\hline PAAZ & $\mathbf{x}$ & $\mathbf{x}$ & $\mathbf{x}$ & $x$ \\
\hline Vutslavingskl. & $\mathbf{x}$ & $\mathbf{x}$ & & \\
\hline Ins. v. kinderpsy. & $x$ & $\mathbf{x}$ & & \\
\hline Psych ger verpl th. & $x$ & $\mathrm{x}$ & $\mathbf{x}$ & $\mathbf{x}$ \\
\hline Zwakzinnigeninst. & $x$ & $\mathbf{x}$ & $\mathbf{x}$ & $\mathbf{x}$ \\
\hline TBR-kliniek & $x$ & $x$ & & \\
\hline \multicolumn{5}{|l|}{ Semimaraal } \\
\hline Med. Kleuterdagv. & $\mathbf{x}$ & & $x$ & $\mathbf{x}$ \\
\hline Med. Kinderteh. & $\mathbf{x}$ & & $x$ & $\mathbf{x}$ \\
\hline Dagziekenh. APZ & $\mathbf{x}$ & $\mathbf{x}$ & $x$ & $x$ \\
\hline Dagbeh. Psychoger. & $x$ & $\mathbf{x}$ & $x$ & \\
\hline Bieschermende woonv. & $\mathbf{x}$ & $\mathbf{x}$ & $\mathbf{x}$ & $\mathbf{x}$ \\
\hline KrisisOpv. & & & $\mathbf{x}$ & $\mathbf{x}$ \\
\hline \multicolumn{5}{|l|}{ Extramuraal } \\
\hline Poli APZ & $x$ & $\mathbf{x}$ & $x$ & $\mathbf{x}$ \\
\hline Poli PAAZ & $x$ & $\mathbf{x}$ & $x$ & $\mathbf{x}$ \\
\hline Poli Kinderpsych. & $x$ & $\mathbf{x}$ & & \\
\hline $\mathrm{CAD}$ & $x$ & $\mathbf{x}$ & $\mathbf{x}$ & \\
\hline RLAGG |incl. IMP| & $\mathbf{x}$ & $x$ & $\mathbf{x}$ & $\mathbf{x}$ \\
\hline Vrig. zenuwartsen & & & $\mathbf{x}$ & $\mathbf{x}$ \\
\hline 24-uurs Opvangp. & & & $\boldsymbol{x}$ & $x$ \\
\hline Soc ped dienst & $\mathbf{x}$ & & $\mathbf{x}$ & $x$ \\
\hline
\end{tabular}

- de RIAGG heeft in beide regio's een groot anandeel in de verleende zorg' (Brook en Hamers 1985, p. 125).

De gevonden verschillen tussen beide gebieden hebben waarschijn lijk van doen met een andere structuur van de GGZ. Zo bleek de poliklimiek van het APZ in het noorden omvangriik in verhouding tot die in het zuiden, maar voor de PAAZ-poliklinieken lag dit andersom. Ook de werkwijze binnen de RIAGG'en blijkt cen belangrijke factor, waardoor verschillen kunnen ontstaan. Door de zuidelijke RLAGG werden beduidend minder jongeren $(0-17$ jaar $)$ behandelld of geregistreerd dan door de noordelijke RIAGG.

Bovendien bleek de semimurale sector in het zuiden omvangrijker. Dat was voornamelijk toe te schrijiven aan de patiênten die voor maxi. maall tien dagen in het KrisisOpvangCentrum werden opgemomen; een voorziening - in deze vorm in het noorden niet anwezig - die, hoewel 
Tobel2: Het antual patienten liaarprevalentiel in het noordelike en zuidelijke registergebucd: naar eerste instelling in $198 \mathrm{II}$ in absolute antallen en per 1000 Intwing

\begin{tabular}{|c|c|c|c|c|}
\hline \multirow[b]{2}{*}{ GGZ voorzieming } & \multicolumn{2}{|c|}{ Noordelike gebied } & \multicolumn{2}{|c|}{ Zuidelike gebied } \\
\hline & Absolurt & per 1000 & Absoluut & per 1000 \\
\hline \multicolumn{5}{|l|}{ Intramuraal } \\
\hline APZ & 119 & 2.63 & 296 & 1.44 \\
\hline PAAZ & 28 & 0.62 & 52 & 0.25 \\
\hline Andere int woorz. & 100 & 2.21 & 581 & 2.84 \\
\hline \multicolumn{5}{|l|}{ Semumuraal } \\
\hline $\begin{array}{l}\text { Med. Klevterdagv. } \\
\text { Med. Kinderteh." }\end{array}$ & - & - & 153 & 0.75 \\
\hline Mied Kinderteh." & & & & \\
\hline Dagzekenh. APZ & 9 & 0.20 & 61 & 0.30 \\
\hline Dagbeh. Pisych G. & 5 & 0.11 & - & - \\
\hline Besch. Woonvoorz. & 4 & 0.09 & 48 & 0.23 \\
\hline KrisisOpvangCentrum & - & - & 128 & 0.62 \\
\hline \multicolumn{5}{|l|}{ Extramuraal } \\
\hline Poli APZ & 215 & 4.76 & 416 & 2.03 \\
\hline Poli PAAZ" & 57 & 1.26 & 529 & 2.58 \\
\hline Poli Kinderpsych. & 0 & 0.00 & - & - \\
\hline $\mathrm{CAD}^{\circ}$ & 103 & 2.28 & - & - \\
\hline RIAGG \incl IMP| & 564 & 12.49 & 2388 & 11.65 \\
\hline Vriig Zenuwartsen & - & - & 261 & 1.27 \\
\hline 24-urs Opwangp. & - & - & 419 & 2.04 \\
\hline Poli zwakz.zorg & 1 & 0.02 & - & - \\
\hline Soc ped. dienst" & - & - & 624 & 3.04 \\
\hline $\begin{array}{l}\text { Total |zonder } \\
\text { dubbeltellingen| }\end{array}$ & $1205^{\prime \prime}$ & 26.68 & $5960^{\cdots}$ & 29.08 \\
\hline
\end{tabular}

" van deze gemerkte instellingen ziin de aantallen in de volgende tabellen niet verwerkt; dit in verband met de wergelijkbaarheid

"* incl consulten ". 4 personen: eerste instelling onbekend.

N.B : Onder andere intramurale voorzieningen wordt verstaan: psychogeriaurisch verpleegtehuis, zwakzinnigeninstituten, instituten voor kinderpsychiatrite, verslawingsklinieken en TBR-kliniek.

Tabel 20: Het aantal patiënten fiaarprevalentiel in het noordelijk en zuidelijk registergebied: naar eerste instelling in 1981 en per echelon in absolute aantalleat en per 1000 inwoners

\begin{tabular}{lrcrc}
\hline & \multicolumn{2}{c}{ Noordelike gebied } & \multicolumn{2}{c}{ Zuidelike gebied } \\
& Absoluut per 1000 & Absoluut per 1000 \\
\hline Intramuraal & 247 & 5.47 & 1057 & $5: 15$ \\
Semumuraal & 13 & 0.29 & 109 & 0.54 \\
Extramuraal & 837 & 18.53 & 4013 & 19.58 \\
Totaal & 1097 & 24.29 & 5179 & 25.27 \\
\hline
\end{tabular}

- Het KrisisOpwangCentrum is thier tot de intramurale sector gerekend 
ex opnamen plaats vinden, door de zuidelijke GGZ als semimuraal getypeerd wordt. (Deze typering liikt terecht, omdat het KrisisOpvang. Centrum gevestigd is in een 'normaal' huis in de binnenstad van Maastricht zonder enige associatie met een klinische setting en omdat de opbouw naar discipline van de staf anders is dan in een klinische opnameafdeling. Wij verwachten met deze studie de eerdere bevindin. gen te bevestigen.

\section{De jaarprevalentie in 1981}

ledereen die gedurende 1981 met tenminste éen GGZ-voorziening in contact is geweest en woonachtig is in een van de beide registergebieden werd meegeteld in het zogenaam de jaarprevalentiecijfer. In tabel 2 is voor beide registergebieden het aantal patiënten per voorziening. waarmee in 1981 het eerste contact plaats vindt, angegeven. Dit is gebeurd om te vermijden dat er in deze tabel dubbeltellingen zouden ontstaan van die patiënten die met meer GGZ-voorzieningen in contact komen. Het totaal aantal patiënten per 1000 inwoners in de desbetreffende populatie (de jaarprevalentie/ was 29.1 in het zuidelijk en 26.7 in het noordelijk registergebied.

De getallen van tabel 2 mogen niet zonder meer met elkaar worden vergeleken, daar van enkele voorzieningen - ofschoon in beide gebieden aanwezig - in een van beide gebieden geen gegevens werden verzameld. In tabel $2 a$ zijn deze voorzieningen buiten beschou wing gelaten; de aantallem van tabel 2 a bieden daarom een betere vergelijkingsmogelijkheid. De voorzieningen die in beide gebieden aanwezig zijn mar in een van beide gebieden niet participeren, zijn in tabel $2 \mathrm{a} \mathrm{en} \mathrm{ook} \mathrm{in} \mathrm{de}$ volgende tabellen niet meegerekend (b.v.het CAD in het noorden en de Sociaal Pedagogische Dienst in het zuiden). De voorzieningen die slechts in een van beide gebieden aanwezig zijn en participeren aan de studie zijn daarentegen wel in tabel $2 \mathrm{a}$ en in de volgende tabellen meegerekend [b.v. de 24-uurs Opvangpost in het zuiden]. Dit gebeurde omdat te verwachten is dat andere voorzieningen de functies van de afwezige vervullen.

Omdat wij vermoeden dat de opmamen die in het KrisisOpvangCentrum /zuiden/ plaats vinden bij afwezigheid van die voorziening in bet noorden in een van de intramurale voorzieningen zullen geschieden, is in tabel $2 \mathrm{a}$ het KrisisOpvangCentrum tot de intramurale sector gerekend. Hoewel deze voorziening als semimuraal getypeerd wordt, lijkt het erop dat zij / ten delej een intramurale functie vervult. Uit tabel 2 a blijkt dat het jaarprevalentiecijfer in het zuiden iets hoger is dan in het noorden (25.3 tegenover 24.3 per 1000 inwoners). Het ciffer in het noorden is sedert 1974 nawwelijks veranderd (Giel en Ten Horm 1976).

De verdeling over de drie echelons geeft geen grote verschillen te zien. Blijken in 1981 in bet zuiden naar verhouding meer patiênten dan in het noorden een extramurale of een semimurale voorziening als 
eerste instelling te hebben bezocht, in bet noorden geldt dit voor de intramurale voomzieningen. Daar zilin naar verhouding meer mensen met het APZ en de PAAZ |als eerste voorzieningl in contact gekomen.

In het zuiden komt een grote groep patienten met het KrisisOpvangCentrum in contact; terwill het dagziekenhuis (dagcentrum en dagactivering) en de beschermende woonvormen in het zuiden in verhouding tot die voorzieningen in het woorden veel vaker als eerste voorzie. ning voor de patiènt fungeren.

Het aantal patiênten dat in 1981 bij de noordelijke APZ-polikliniek begint blikt groot in verhouding tot de polikliniek van het APZ in het zuiden; voor de PAAZ poliklinieken ligt dit precies andersom. Hierbii dient te worden opgemerkt dat de PAAZ in het noorden zowel klinisch als poliklinisch in 1981 gedurende een periode van zes maanden gesloten is geweest. Het is daarom duidelijk dat de PAAZ in dit vergelijkend onderzoek onvoldoende naar voren komt aangaande zijn plaats en functie binnen de GGZ in het noorden.

Beide RLAGG'en zien als eerste voorziening in 1981 per 1000 inwoners ongeveer evenveel patiënten. Daarbij moet echter worden bedacht, dat met name de RIAGG in het zuiden relatief veel weigeraars $112 \%$ in 1981 in haar populatie heeft. Als daarvoor wordt gecorrigeend dan kwamen er 13.2 patiënten per 1000 van de zuidelijke bevolking naar de RIAGG als eerste instelling tegenover 12.5 in het noordelijk registergebied. Laten we de z wakzinnigenzorg buiten beschouwing en beperken we ons tot de GGZ in engere zin dan ontstaan de volgende jaarprevalentiecijfers: in het zuiden $23.5(\mathrm{~N}=482$ l/ en in het noorden $22.9|\mathrm{~N}=1033|$.

In tabel 3 zijn de aantallen personen aangegeven die gedurende 1981 in contact kwamen met de verschillende GGZ-instellingen.

Wat bet reft de intramurale sector is uit tabel 3 af te lezen dat er in het zuiden gedurende een jaar meer patiënten per 1000 inwoners in een psychogeriatrisch verpleegtehuis zijn opgenomen dan in het moorden [zuiden: 1.1 en noorden: 0.61. Daarbij moet wel bedacht worden dat in beide regio's een deel van de APZ'en in feite functiomeerden als een psychogeriatrisch verpleeghuis, maar in beide regio's tot het APZ is gerekend. De aantallen voor de PAAZ in teide gebieden liggen dichter bij elkaar (zuiden: 0.67 en noorden: 0.88 ).

Er is een groot gantal personen in het zuiden dat (kortdurend] wordt opgenomen in het KrisisOpvangCentrum |1.6 per $1000_{;}$in het noorden is deze voorziening niet aanwezig). Daartegenover staat, dat in het noorden anzienlijk meer patiènten in het AFZ werden behandeld (noorden: 4.1 en zuiden 2.3 ). Er is in het zuiden een werhoudingsgewijs groot antal patiënten in contact met het dagzieken huis van bet APZ of opgenomen in een beschermende woonvorm.

Binnen de extramurale sector is te zien dat de RIAGG in beide gebiedien longeveer even) veel personen in behandeling heeft (zuiden: 12.3-gecorrigeerd voor weigeraars: 14.0 -en noorden: 13.2 | en dat de 
Tobel 3: Het aantal patiënten gedurende 1981 in contact met tenminste én GGZ voorziening |exclusief de zwakzinnigenzorg en de eerder angegeven voorzieningen] in absolute aantallen, per 1000 in woners en als aantal dat eerder in 1981 met een andere instelling in contact was fin absolute antallen en horizontaal gepercenteerd

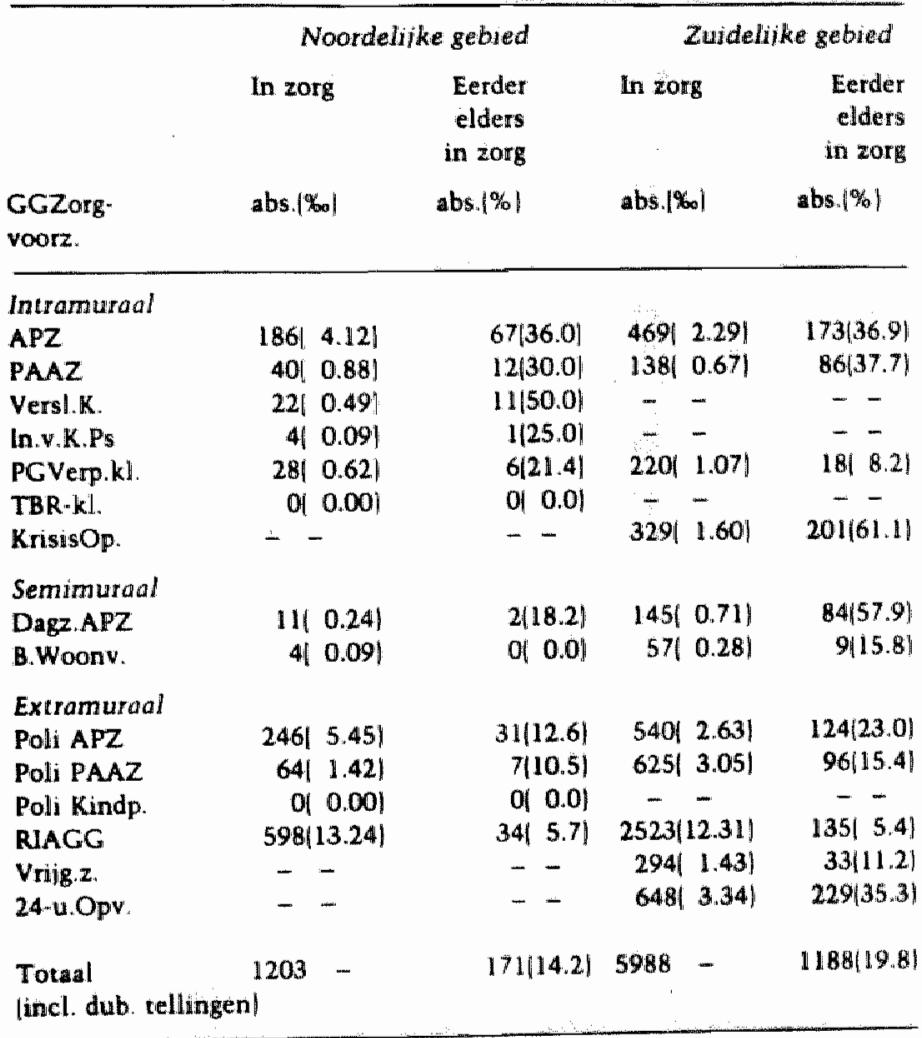

poliklinieken (APZ en PAAZ) en de vriigevestigde zenuwartsen (in het zuiden) tesamen ongeveer evenveel patiënten per 1000 inwoners in zorg hebben (zuiden: 7.1 en noorden: 6.9). Ten slotte valt op dat een grote groep patiënten gedurende 1981 met de 24-uurs Opvangpost lín het zuiden) in contact komt (3.3 per 1000, in het noorden is deze voorziening niet aanwezig).

Bij twee noordelijike voorzieningen [niet aanwezig in de zuidelijke regio) blijken in 1981 geen patiënten - woonachtig in de registerregioin behandeling te zijn geweest, namelijk de TBR-kliniek en de Polikliniek voor Kinderpsychiatrie.

In tabel 3 staan ook de antallen personen vermeld die voordat zij 
met de betreffende instelling in contact kwamen in 1981 reeds bii |minstens) ến andere instelling in zorg zijn geweest (in absolute aantallen en als percentage van het totaal aantal bij de betreffende instelling in 1981 in zorg). De percentages liggen in bet zuiden over het algemeen hoger. Vooral de verschillen tussen de noordelijke en de zuidelijke semimurale sector en in iets mindere mate tussen de noordelijke en zuidelijke PAAZ - en APZ-poliklinieken zijn opmerkeliik. Anders ligt dit bij de psychogeriatrische verpleegklinieken; in het zuiden $(8.2 \%)$ zijn minder patiênten elders gewreest dan in het noorden $|21.4 \%|$. De RLAGG'en (in het zuiden $5.4 \%$ en in bet noorden $5.7 \%$ ) verschilden niet.

Tabel 4: De patièntenpopulaties [exclusief de zwakzinnigenzorg en de eerder aangegeven voorzieningen |: leeftijd tegen geslacht in absolute aantallen en per 1000 inwoners in de betreffende categorie

\begin{tabular}{|c|c|c|c|c|c|c|c|}
\hline & \multicolumn{6}{|c|}{ Noordelijke gebied (van twee is het geslacht on bekend) } & \\
\hline & \multicolumn{2}{|c|}{ Mannen } & \multicolumn{2}{|c|}{ Vrouwen } & \multicolumn{2}{|c|}{ Tatas } & \\
\hline & $\begin{array}{l}\text { Abso: } \\
\text { luut }\end{array}$ & $\begin{array}{l}\text { per } \\
1000\end{array}$ & $\begin{array}{l}\text { Abso } \\
\text { luut }\end{array}$ & $\begin{array}{l}\text { per } \\
1000\end{array}$ & $\begin{array}{l}\text { Abso- } \\
\text { luut }\end{array}$ & $\begin{array}{l}\text { per } \\
1000\end{array}$ & \\
\hline $0.17 \mathrm{jr}$. & 99 & 16.1 & 78 & 12.9 & 1.77 & 14.5 & \\
\hline $18.29 \mathrm{jr}$ & 100 & 21.2 & 130 & 26.0 & 230 & 23.6 & \\
\hline $30.44 \mathrm{jir}$ & 93 & 20.6 & 98 & 21.8 & 191 & 21.2 & \\
\hline 45-64 & 114 & 26.7 & 117 & 24.7 & 231 & 25.71 & \\
\hline $65-74 \mathrm{jr}$ & 18 & 13.8 & 37 & 21.8 & 55 & 18.3 & \\
\hline 75 jr. e.o. & 32 & 42.0 & 96 & 66.5 & 128 & 58.0 & \\
\hline Onbekend & 8 & - & 11 & - & 19 & - & \\
\hline Totaal & 464 & 21.3 & 567 & 24.3 & 1031 & 228 & \\
\hline
\end{tabular}

Zuidelijke gebied (van 3 I is het geslacht onbekend!

\begin{tabular}{lllll}
\multicolumn{2}{c}{ Mannen } & \multicolumn{2}{c}{ Vrotuwen } & \multicolumn{2}{c}{ Thotalal } \\
abso- per & abso- per & bso* & per \\
luut 1000 & luut 1000 & luut 1000
\end{tabular}

\begin{tabular}{|c|c|c|c|c|c|c|c|}
\hline $0.17 \mathrm{jr}$. & 160 & 6.1 & 112 & 4.5 & 278 & 5.4 & \\
\hline $18-29 \mathrm{it}$ & 425 & 20.4 & 589 & 29.6 & 1017 & 24.9 & \\
\hline $3044 \mathrm{ir}$ & 792 & 34.5 & 757 & 35.4 & 1550 & 35.0 & 29.1 \\
\hline $45.64 / r_{0}$ & 570 & 26.2 & 628 & 27.8 & 1199 & 27.0 & \\
\hline $45.64 \mathrm{ir}_{\mathrm{n}}$ & 570 & 26.2 & 628 & 27.8 & 1199 & 27.0 & \\
\hline $6574 \mathrm{kr}$ & 89 & 13.9 & 145 & 17.3 & 236 & 16.0 & \\
\hline 75 it eo & 159 & 47.2 & 364 & 59.3 & 528 & 55.5 & \\
\hline onbekend & 0 & - & 0 & - & 13 & - & \\
\hline Totaal & 21195 & 21.6 & 2595 & 25.1 & 4821 & 23.5 & \\
\hline
\end{tabular}


Het hoge percentage patiënten bij het KrisisOpvangCentrum (zuiden) dat in 1981 reeds eerder met een andere voorziening in contact is geweest, wordt verklaard doordat de meeste personen die daar worden opgenomen al een ambulant contact met de 24-uurs Opvangpost hebben gehad. Opmerkelijk is de grote groep patiënten bij de 24-uurs Opvangpost in het zuiden die reeds elders in behandeling is geweest $|35.3 \%|$.

\section{Enkele kenmerken van de patièntenpopulaties}

Eerder constateerden wij dat de zuidelijke en de noordelijke patiëntenpopulaties in de puntprevalentietelling wat betreft de leeftijdsopbouw van elkaar afweken; in het zuiden bleken jongeren $(0-17$ jaar $\mid$ per 1000 inwoners minder in behandeling te zijn. Dit kon worden toegeschreven aan het gegeven dat door de zuidelijke RIAGG minder jongeren werden behandeld of geregistreerd.

In tabel 4 is af te lezen hoe beide patiêntenpopulaties in de jaarprevalentie naar leeftijd en geslacht zijn opgebouwd. In deze tabel zijn de aantallen per 1000 inwoners opgenomen in de desbetreftende leeftijds/ geslachtscategorie om een optimale vergelijking tussen beide registergebieden te presenteren.

Het jaarprevalentiecijfer voor de populatie van 18-64 jaar is in thet zuiden hoger dan in het noorden 29.1 per 1000 inwoners in het zuiden en 23.5 in het noorden|. Dit hogere zuidelijke prevalentieciffer is toe te schrijven aan de omvangrijke groep van 30-44 jaar die in het zujden in behandeling is.

In het zuidelijke registergebied hebben vrouwen in alle leeftijdsklassen, uitgezonderd die van 0-17 jaar, een grotere kans om met de GG $Z$ in aanraking te komen dan mannen; dit geldt ook voor de patiènten in het noorden uitgezonderd voor de leeftijdsklassen van 0-1 7 en 45-64 jaar. In beide registergebieden bebben mensen ouder dan 75 jaar de grootste kans om met de GGZ in aanraking te komen; dit geldt vooral voor vrouwen ouder dan 75 jaar en in iets mindere mate voor mannen ouder dan 75 jaar. De leeftijdscategorie van $65-74$ jaar blijkt in beide gebieden een relatief lage kans te hebben met de GGZ in aanraking te komen.

Ten slotte is voor diegenen die in 1981 intramuraal zijn behandeld de verdeling naar diagnose en leeftijd gegeven. Voor diegenen die meer diagnosen kregen doordat ze met meer (intramurale) voorzieningen in contact zijn geweest, is een 'kerndiagnose' vastgesteld volgens de hiërarchie van Giel (1978).

In het zuideliike registergebied heeft een groot deel van de intramurale populatie de diagnose dementie gekregen $|34.4 \%\rangle$; in het noorden is dit percentage lager $(20.5 \%)$. In het noorden komt de diagnostische categorie neurose het meest voor $(26.5 \%$; in het zuiden $22.1 \%)$; de psychosen daarentegen komen in het zuiden meer voor $129.0 \%$; in het noorden $22.3 \%$ ). Verslavingen ten slotte komen in het noorden meer 


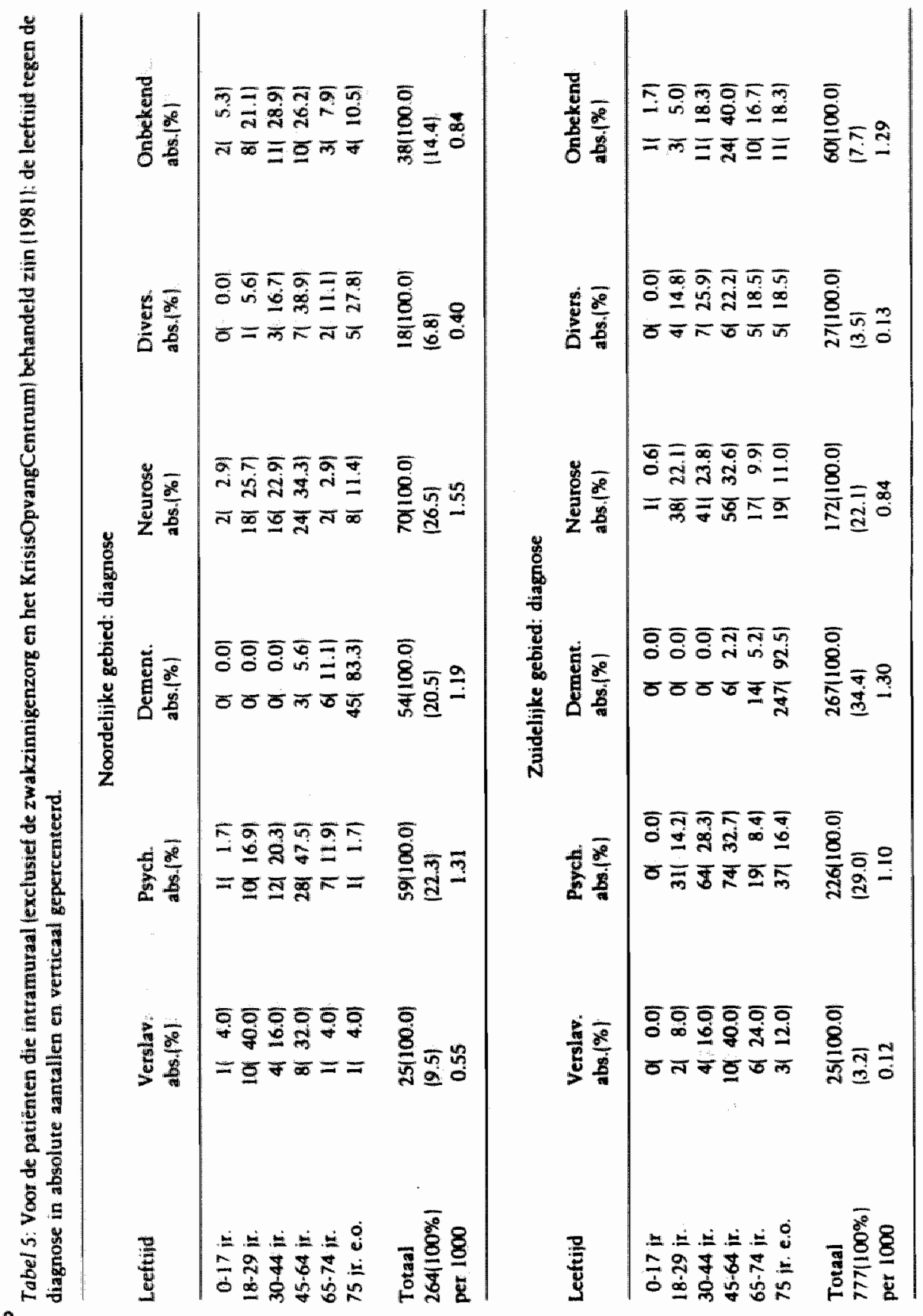


voor $19.5 \%$ tegenover $3.2 \%$ in het zuiden|. De verdeling naar leeftijd binnen de diagnostische hoofdgroepen geeft geen grote verschillen te zien. In tabel 5 zijn de diagnosen per 1000 van de desbetreffende bevolking weergegeven. Het blijkt dat in thet noorden de verslavingen en de neurosen per 1000 van de bevolking vaker intramuraal behandeld worden, terwil dit in het zuiden voor dementie opgaat.

\section{Discussie}

Een groot deel van onze eerdere bevindingen konden hier worden bevestigd. Wat intrigeert is echter het volgende verschil. In de puntprevalentiestudie constateerden wij niet die grote verschillen tussen beide gebieden ten aanzien van de intramurale sector. Noor het APZ vonden wij dichtbij elkaar liggende puntprevalentiecijfers \{zuiden: 1 .0 en het noorden: 1.1); voor de PAAZ gold dat in mindere mate /zuiden: 0.1 en het noorden: 0.21 .

Voor de psychogeriatrisch verpleegkliniek bleek dat er op een punt in de tijd in het zuiden meer personen waren opgenomem dan in het noorden (zuiden: 0.7 en noorden: 0.3 . Als we voorgaande drie voorzieningen tesamen nemen dan bleken er op één tijdstip per 1000 inwoners ongeveer evenveel (APZ, PAAZ en psychogeriatrischel bedden bezet te zijn (zuiden: 1.8 en noorden: 1.71). Maar in een jaar tijd werd er in het zuiden door minder personen gebruik gemaakt van deze drie voorzieningen tesamen dan in het noorden (zuiden: 2.7 en noorden: 3.7 ). Met eventueel dubbelgebruik van voorzieningen binmen APZ.PAAZ-Verpleegkliniek is hier geen rekening gehouden.

Een deel van de verklaring is, dat in het zuiden een groep patiënten met de diagnose verslaving buiten het gezichtsveld van het register blijft. Echter, het lijkt belangrijker in herinnering te roepen dat er vele kortdurende opnamen binnen het KrisisOpvangCentrum in het zuiden plaats winden, een deel wan deze opnamen zal bij afwezigheid van deze voorziening in het noorden vermoedeli $k$ binmen andere intra murale voorzieningen plaats vinden. Bovendien zijn de semimúrale voorzieningen in het zuiden qua omvang verder ontwikkeld dan in het noorden.

Een ander verschil is, dat er door de zuidelijke patientenen vaker contact wordt gelegd met meer voorzieningen. Dit geldt vooral voor de patiënten in behandeling bij de semi - en de extramurale voorzieningen. Waarschijnliik maakt de hulpverlening in het zuiden meer anspraak op andere voorzieningen om mogelijkheden, die men zelf niet in huis heeft, te benutten |zie voor een uitwerking van dit onderwerp: Hamers e.a. 1985). Daarnaast speelt cok de wijze waarop de 24-uurs Opvang" post gestalte heeft gekregen een belangrijke rol, omdat deze voorziening mede is opgezet om de continuiteit van zorg ten behoeve van de patiênten, die elders in ambulante of intramurale zorg zijn of zijn geweest, te waarborgen (Hamers 1983). 
Ten slotte constateerden wij dat de jaarprevalentie voor de totale bevolking in beide gebieden vrifwel gelijk is. Voor de leeftijdsklasse van 18-64 jaar is de jaarprevalentie in het zuiden echter hoog in vergelijking tot die in het noorden Anderzijds kan de vraag gesteld worden in hoeverre er in het zuiden lacumes zijn woor wat betreft de hulpverlening aan jonge mensen $10-17$ jaar]. Vergelijken wij de jaarprevalentiecijfers met die welke met behulp van registeronderzoek in Groot-Brittannie verkregen werden (Goldberg en Huxley 1981 ), dan zijn beide Nederlandse prevalentieciffers hoog. Dan dient men bovendien nog te beseffen, dat in de hier gepresenteerde informatie de gegevens betreffende de zwakzinnigenzorg en het $\mathrm{CAD}$ ontbreken.

In onze eerste publikatie noemden wij vooral de geconstateerde overeenkomsten frappant, juist omdat de structuur van de GGZ in beide gebieden nogal van elkaar verschilt. De hier geboden informatie brengt een aantal verschillen tussen beide regio's naar voren, verschillen die wellicht de regionalle beleidsopvattingen in de twee gebieden weerspiegelen en van doen kunnen hebben met de specifieke situatie in het zuiden waar de laatste jaren pogingen ondernomen worden om intramurale behandelingsvormen door semi- of extramurale te vervangen onder andere door een restrictief opnamebeleid te hanteren en het daarnaast met name in het APZ een algemene beleidslinn is de opnameduur zo beperkt mogelijk te houden. Bovendien wordt er in het zuiden door de grotere GGZ-voorzieningen op beleidsmatig/b.v. RIGG en de voorlopers daarvan/ en op hulpverleningsniveau /b.v. het psychogeriatrisch circuit en de 24-uurs Opvangpost) all een aantal jaren concreet samengewerkt; men mag verwachten dat dit in de cijfers tot uitdrukking zal komen.

Tot slot is een waarschuwing op zijn plaats. Om de getallen juist te interpreteren dient te worden bedacht dat zij vooral een afspiegeling zijn van de fomvang van del zorg, zoals die wordt aangeboden vanuit een voor ieder ge bied specifieke constellatie van de GGZ. De bevindingen mogen niet zonder meer gebnikt worden als indicator voor de behoefte aan zorg vanuit de bevolking.

\section{Literntuar}

Baldwin, A A (1973), Linked record medical information systems. Proc. R. Soc. Lond. 184, 403.

Brook, F. G., en H.J.F.R. Hamers (1985), GGZorg gepeild. Een vergelijkend onderzoek met behulp van twee registers voor de geestelijke wolksgezond. heid. Tidschrift voor Psychiatrie 27, 115-127.

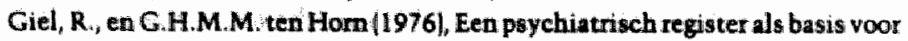
planning. Tijdschrift voor Sac. Geneeskunde 54, 146*153.

Giel, R. (1978), Over de classificatie in disgnostisch opzicht van elienten. Afd. Sociole Psychiatrie, RU Groningen.

Goldberg, D. en P. Huxley, (1981), Mental illness in the Community. Londen. 
Hamers, H.J.F.R. [1984\}, Onderzoek en privacy, De praktijk van een dilemma, Perspectief fintern tijdschrift Sociale Psychiatrie Masastricht/ $51-63$.

Hamers, H.J.F.R. (1983), De 24-uurs Opvangpost voor acute psychosociale en psychiatrische crises in de regio Masstricht. Tijdschrift voor Sociale Gezondheidszorg 61, 802-805.

Hamers, H.J.F.R. M.A.I. Romme en G.A.M. Driessen [1985 I, Het fon/bedoelde gebruik van meer GGZ voorzieningen. Tidschrifi voor Sociale Gezondheidszorg 63, 506-511.

Hoek, H.W., F.G. Brook, R. Giel en G.H.M.M. ten Hon «1984», Anorexia Niervosa. Tijdschrift voor Psychiatrie 26, 736-744.

Vrues, M.W. de en H.J.F.R. Hamers [1984], Mental health care and morbidity. The use of the case register in refiningepidemiolegical research. Tijdschrift voor Saciale Gezandheidszorg 62,504-506.

Wing, I.K, en A. Hailey (1972), Evaluating a Community Psychiatric Service: Camberwell Register 1961-1971. Oxford Press, Oxford 
H.I.F.R. Hamers and F.G. Brook

The treated year-previlence of meatal illness in two register-areas

Year-prevalence figures from two Dutch psychiatric cuse-registers have been compared. Although the findings suggest some remarkable similarities, there seem to exist some differences between the mental health care in both areas.

In general we could replicate our first comparative findings /one-day prevalencel. In both areas most people contacted out-patient services, especially the so called Regional Institutes for Ambulatory Mental Health Care (RLAGG).

The diagnostic distribution showed some differences for the patients who were admitted. 
7.2.3.

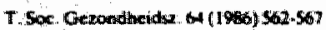

\title{
DE GEESTELIJKE GEZONDHEIDSZORG EN HAAR RISIKOGROEPEN
}

\author{
H. J. F. R. Hamers, G. A. M. Driessen
}

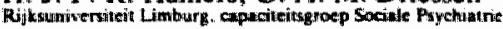

Met behulp van een psychiatrisch case register werden voor onderscheiden leeftijds burgerlijke staat karegorieën de administratieve incidentiecijfers (per 1000 inwoners in de desbetreffende kategarieën) bepaald. Hierwit bleek dat er enkele risikogroepen in de populatie aanwezig zijn: sommige kategorieên komen meer dan verwach met de $G G Z$ in aanraking, andere minder. 


\section{INLEUDNGG}

Uit diverse bevolkngronderzokingen blijk dat niet iedeteen in en populatie dezelfde kans heeft psychische stont

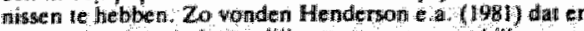

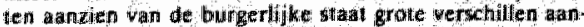
wexig zijin in do prevale atiegutallen. Onder te gescheiden peromen wenden de grootste prevalenterates gehonsta tiet meter menten problemen aangarande thum geestelijle gezond heid hetben.

In ons land werd en heine then jaar geleden een omvang rijk bevolkingsonderzoek (BAVO-rapport 1978) uiligewoerd: de gegevens wan dit ondenotik werden onlangs werder geanalyseerd en gepubliceerd (Offerhaus, 1964l). Hieruit blete dal zowel de ervaren problemen alsook de

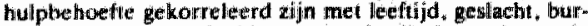
gerlijlce stabl, sociale klasse en urbanisatiegraed van de Woonplatats

Ment mag dan ook verw dehterin, dat een aantal kategoneten in de geestelijke gezondheidszorg (GOZ) owerwertegen. woordigd zulten zijn. Exhter zoals bekend komt slechts een zeer klein deel van die mensen met psychische stoornissen in kontakt met de GGZ; tusten de populatie en de GGZ funktioneten enkele fitters (Goldberg 1981), waarbij o a. aen de huisarts eer belanginjke rol wordt toegekend. Bowendien wordt het aantal personen dat met de GGZ in kontakt komt, warschijnlijk in hoge nrate bepaald door de omving de toegankelijkthe id en de verondersteide of ervaren effelktiviteil wan de: $\mathrm{GOZ}$

Sprekend over de paitenten in behandeling bij de GOZ, mogen wif dus niet zonder meet vaststellen. dal bepaalide kategorietin - omdal zij zi overwertegenwoordigd - een slechtere geestelijke gezondheid bezitten. Ondanks dai, is het frappanu dal in de G GZ kategorieên overweregenwoordigd zijm. die vanuit de resultoten van bevolkingsonderzoe. kingen als risicogroepen geoormerkt zijn.

Zo bijw. vand mern in enkele recente vergelifkende studies. dat hoogbejalarden meer dan gemiddeld in behandeling bij de GOZ waren (Brook \& Hamers 1985, Hamers en Brook 1986). Soortgelijke bevindingen werden al eerder gewon* den: zowel als de gethele intramurale GGZ in Nederland bekeken werd (Van Weerden en Giel 1975) alsook indien men de bij de gehtele $G G Z$ in behandeling zijnde populatie van een regio onderzocht (Giel en Ten Horn 19,8).

Hier willen wij rapporteren ower mogelijke risikogroepen in

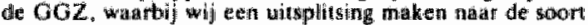
zorg die onivangen wordt. Naast de wrats wie heeft een

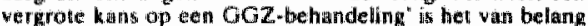
oan lie geven wie exi overgrate kans heef intramuraal bellarideld te worden; ond tht tow ianngenomen mag wordien dal dit in thet alge meen dhe rnstiger women van prychopathologie betteft.

Ten slotte: indien angetoond kam wordien, dat in werschil- lende gebieden dezellde risih ongropen annwezis zijn, heb ben wij een goede aanleiding te veronderstellen dat er welliswarar filters bussen de populatic en de GGZ zijh, maar dial deze filters nilet selectief werken. De popsilatie in behandeling bij de COZ geeft dan eentwerspiegeling wan wat in de populatie aan psychische stownissen abnwezig is on welke kategoriees - b. w. naw demografische vanabelen een wlechtere geesielijke gezondheid bezituen.

\section{METHODE}

Om de yragen te be:antwoorden is gebruik gemaak! van gegevens opgeslagen in thet register wor de $G G Z$ in de regio Maastricht e ou (popolatie ca. 200,000). Dit registert is opgezet natar analogic van hell register woor eem middelgrote gemeente in het noorden van Nedertand (Giel en Ten Horn 1976)

Het belangrijkste kenmerk van cen dergelijk register, is da: de geqevens van de patienten in behandeling bij de $G G Z$ op en centralle plaats bijeen gebracht worden en de gegevens per patientent agneengelkoppeld worden. Deze koppeling is wanwege privacyoverwegingen opgezet als een warschijn lijkheidskoppeling (Baidwin 1973. Hamers e.a. 1986) waarbij de naam van de patiēnt voor de onderzoekers onbekend blijt. Omdat het aantal patienten. dat gedurende een jalar in kontakt met rwee of meer GGZ-4oorzieniagen bome. mroot is - in 1981 bijna 20e (Hamers e.a. 1985) - is het alleen middels een register praktisch mogelijk om (administratieve) incidemite- en prevalentietellingen uni te voeren; $d, w, z$. zonder dat er dubbettellingen plaatswinden. Over 1981 zîjn de patienten bepaald die - na de drie fastste maanden in 1980 geem behandeling in de $G G Z$ te the bben ondergaan - nieuw in de GGZ verschijnen; de $Z_{*} g_{\text {in }}$ incidem tiegevallen".

$\mathrm{Om}$ te onderscheiden naar soort $\mathrm{zorg}$ hebben wij aparie groepen patiënten gevornd; n.l. diegenen die gedurendo 1981 alleen met de extramurale $G G Z$ in aanraking kwamen en die patienten die (ook) bij lenminste een intral of een semimurale voorziening in behandeling geraakten (al dan miet gekombineerd met extramurgle zorg).

Alvorens wij de eigenlijke analyses gestan zijn. is gekon troleend of de gehantee rdie variabelen gekorreleerd zijn met de eersiste kontaktdatum in 1981 . Dit bleek niet lhet geval: alle te bespreken kategoriez̃n patienien hebben ewenweel tijd in 1981 om met bepaalde voorzieningen in aanraking te komen.

De resultaten worden grotendech in grafickworm gepresen teerdi daabij: worden telkens de aantallen patienten per 1000 inwoners in de desbetreffende kategorie weerge. geven.

\section{RESULTATEN}

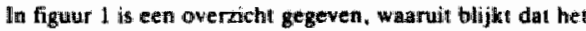

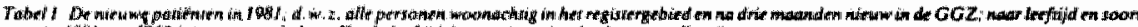

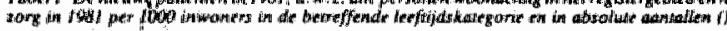

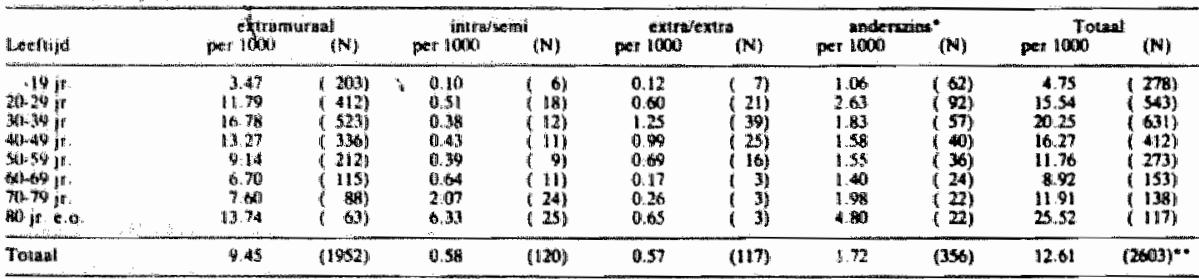

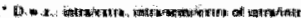

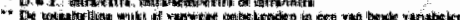




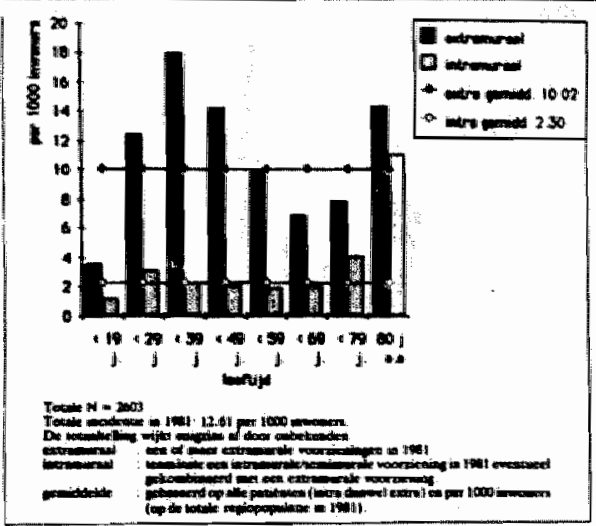

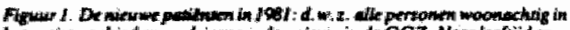

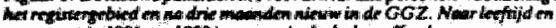

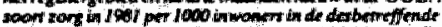

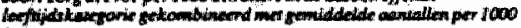
Gumenims.

incidentiecijfer in 1981 voor de regio Maastricht e.o. 12.61 per 1000 inwoners is (zic ook tatuel 1).

Vanwege de leesbaarheid hebben wij in de grafieken gemiddellden opgenomen, wardoor gemakkelijk gflecsbatar is in wellke kategoriezn duidelijk afwijkend in positieve of negaHieve zin scoren. Voor wille kategoriećn gezamenlijk is het extramurale (alleen extramurale zorg in 1981) incidentiecijfer 10.02 en hel intramurale (met nentminste een intra/ semimurale vooratening in kontakl gedurende 1981 al dan niet gekombineerd met een extramurale voorziening) incidentiecijfer 2.30 per 1000 iawoners. Duidelijk is te rien dat met het stijgen van de leeftijd - boven de 70 jaar - de kons groter wordi met de GGZ in aniraking te komen: dil geldi vooral voor wat betreft de intramurale zorg. De leeftijdsk a. tegorie van 30.39 jaar - en in iets mindere mate de groep daaromder en daarboven - kent grote aantallen per 1000 inwoners in de destbetreffende kategorie extramuraal in behandeling. terwijl de kategorie $20-29$ jaar meer dan gemiddeld intramuraal in behandeling komt.

in figutur 2 is naar burgertijke stabl weergegeven hoeveet patienten er per 100 in inoners in de desbetreffendie katego-

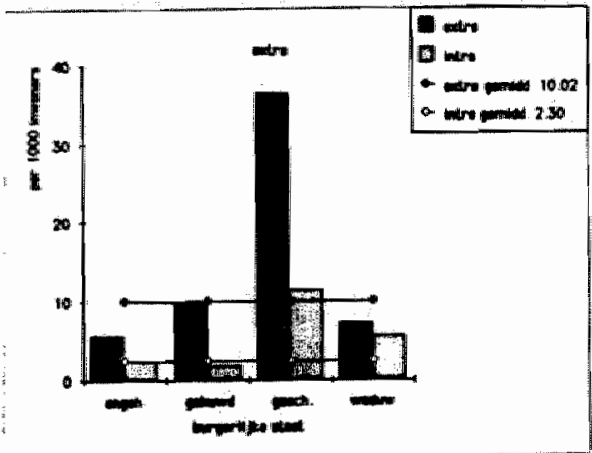

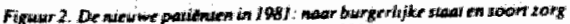

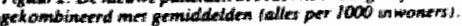

rie in behandeliqg komen: ook is een onderscheid gemaakt naar soort zorg. De kategorie gescheidenen scoort dutdelijk hoger dan gemiddield wat betreft zowell de exina. ahook de intramurale zorg. De kategothe weduwshat scoort how wat betreft de intramuirale zork, malar la ag wat betrefit de extramurale zorg: die ongehuwden en de gehwwden blijwen vooir beide soorten zorg onder het gemiddelde

Dabr leeftijo en burgerlijke tail met elkan wan dowen bebben is hel noodtakelik om meer gedetaille rd te bezien hoe de getallen per 1000 yoor de te ondersoheiden kalegom rieén - naar lewfijd. geslacht en bargenlijke staat - uttvallen.

In figuur 3 a zijn de a antallen (per 1000) ongehuirude vrouwe. bije incidentiegewallen weergegeven en wel nat soort zorg gedurende $198 \mathrm{j}$. Om vergelijkingen mogelijk te maken is diarower de leeftijdsverdeling naar norg voor de totale patientenpopulatie per 1000 inwoners geprojecterd. Untitar muraal walt op, dat de ongehuwde vrouwen in alle leeftijids. kategorieten hoger dan gemiddeld witkomen; extramuraal geldi dat nok witgezonderd woor de oudere ongehuwde vrouwen $(70+)$ en de jonge ongehuwde vrouwen $(0-19$ jaar). Uhi figuar $3 b$ blijh dat vanuit de kategotie gehwiwde wrouwen in het algemeen er minder als paticait in de 002 verschijen. De witzondering betreft de gehuwde vrow wen van sol jas en ouder in extramurale behandeling en de jongste kategorie gehuwde vinouwen (zowel extramaras" alsook intramuralal in behandeling). Wat twetreft de wedu. wen (figuar 3c) is hei opvaliend dat jonge wedturwen meer dan gemiddeld exiramuraal behandeld worden. terwijl intramuraal de kategorieèn $50-59$ jatr en 70 jaar en ouider hoger dan gemiddeld scoren. Afgezien vain de jonge wedu. wen scoren de andere leeftijden extramuraal laiag. De kategorie gescheiden wrouwen (figuur 3d) geefi voor srijwell alle beftijdskategoriectn grote aartallen per 1000 inwoners te zien. Dit gejdt voor zowel de intramurale zorg alsook de extramurale zorg.

Vogr de mannen hebben wij een analloge serie van vier grafieken opgenomen.

Uit figuur $4 a$ blijkt dat ongehuwde mannen in hel algemeen minder dan gemiddeld extramuraal, maar meer dan gemiddeld intramuraal in zong komen. De gehuwde mianen (figuur 4b) komen zowiel intra - alsook extramuraal in hes algemeen minder dan gemiddeld in behandeling. terwijl de weduwnater (figut $4 k$ ) cen expramurale piek wor de kategorie van $40-49$ jatar kennem. Intramurasi scoren de

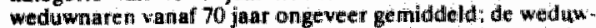
naren vam 60 tot 70 jaar komen intramuinal moer dary gemiddeld in behandeting

De gescheiden marinen (figutu 4d) scoiren in het algerween (intira en extramuraal) duidelijk hoger dan gemuddeld Vergelljken wij mannen en wrowwen in de diverse leefindth en burgerlijt staat kategorieen, dan blijki dai ongehuwde vrouwen (per 1000 inwoners in de destetreffende katego. rie) meer kans hebben in behandeling te komen ofan onge hutwde mannera. Ongehuwde maninen hebben meer kan. antramuraal behmindel te worden; ongehuwde vrouwet hebben intra- en extramurat een megr dan gemiddelde: kins met GGZ in kontakt te komen.

Gehuwde mannen blijken in thet algemeen hoger te sorren dian gehurde yrouwen (uileratard weer per loow inwoners in de desbetreffende kategorie ) gefhuwiden sconen echter voor de meesite leefijidskategorien minder dan gemiddeld. De weduwen en weduwnaks geven beiden een phick te zien als zij relatief jomg zijn (en dam gatat het voomanelijk om extramurale behandeling): op hogere letefijd secorom beide kategorie en minder dan geniddeld. Gescheiden vrouwen bomen (per 1000 inwoners in de betreffende kategarie? meer in thehandeling dan manuten: beidle kategoriegn geschelidenen hebbein in vrijwel alle leefrijdshategorien een meer dan ge middelde kars om met de $\mathrm{GGZ}$ in a nrak ing 

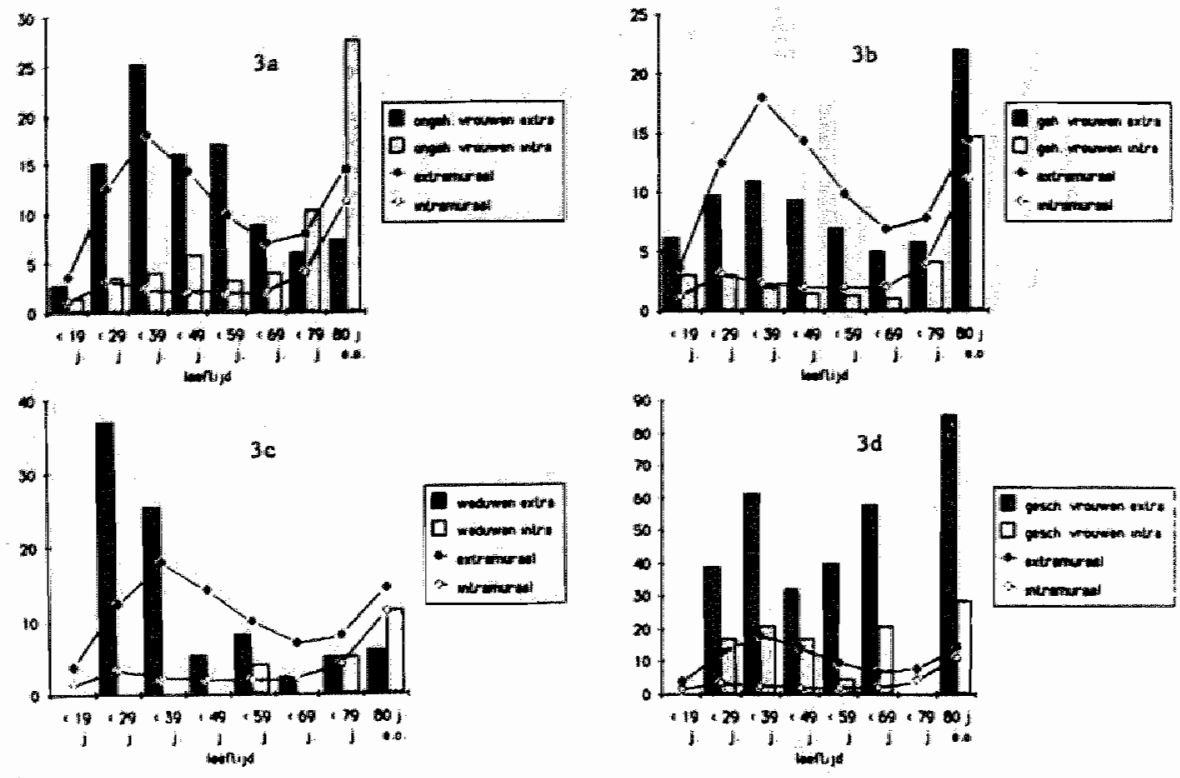

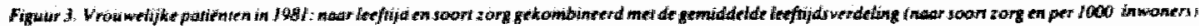
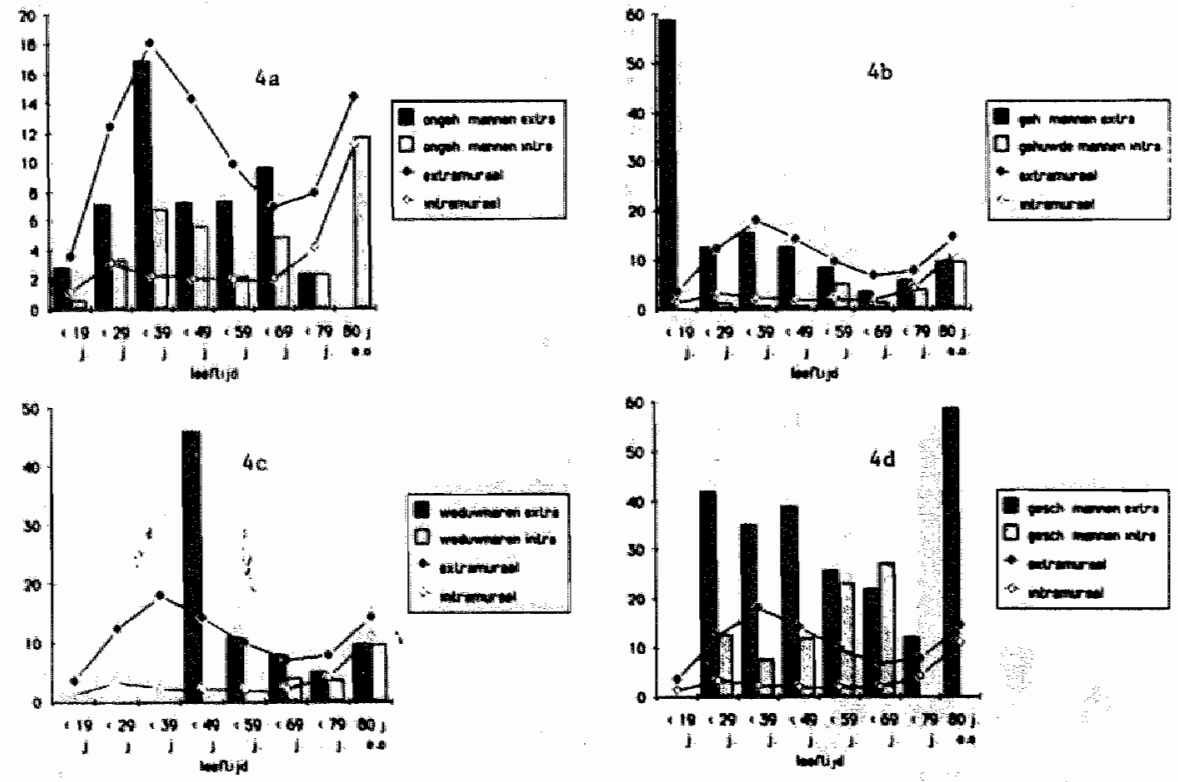

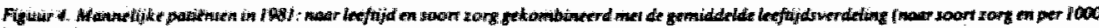

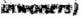


te komen.

Tot nu toe hebben wij enkele kntegonieen de revue laten passeren, zoals die voor de gehele regio in behandeling komen. Echter binner de repio kent de stad Maastricht een hoger incidentieciffer dan het owerige deel, grotendeets bestand uit rurasil en gesuburbaniseerd gebied. Bovendien blijgta de stad Maastricht, indien deze maar bwurten wordt opigedeeld. een grote variacie te kernen in het incidentiecijfer. Het wall buiken het kader hier ower deze resullaten uritgetoreid te rapporteren. Wel is ons gebleken dat er ongeacht de geikozen geografikche eenheid (te weten de buwrten van Magsitricht en het meer ruraal deel van de registerregio) met narne de kategorie gescheidenen zeef geprononceerd als risticogroep naar voren kwam. Anders gezegd: cen geografische eenheid met een hoog incidentieciffer bent een (zeer) hoog incidentiecijfer voor de gescheiden populatie, misar diatzelfde geldt ovor een geografische eenheid met een Ia ag incidentiecijfer.

Samenvartend bleck diat het incidentiecijfer - 12.61 per 1000 inwoners - ten zeer globalal cijfer is en dat er een grote variatie bestaat als gekeken wordi naar kategoneten gevormd door leeftijd, geslacht en burgerlijke staat. Ook bleck dat cen opdeling van de gehele registerregio naar diverse geografische eemheden verschillen te zien gaf met betrekking tot thet incidentiecijer.

Daamaast is het duidelijk dat sommige kategorieetn in sterke matke op de intramurale zorg aangewezen zijn, terwij] andere kategorietn wrijwel alleen maat - zij bet enkele in sterke mate - gebruik maken van extramuralle GGZ voorzienirgen.

Als niet nat soon zorg gespecificeerd wordt, dan blijken de katogorieen ongehuwde mannen en vrouwen tot 20 jaar weinig in behandeling te tomen (resp: 3.44 en 4.21 per 1.000); ook gehuwde zestigers blijken per 1000 inwoners in die leeftijdskategorie maar weinig met de GGZ in aanraking te komen (mannen en vrouwen resp. 4.71 en 6. 10).

De gescheidenen sconen over alle leefilijden hoge aantallen per 1000 . Het is opvallend dat de dertigers in vrijwel alle kategoriečn (geslacht en burgerlijk stagi) grote aantallen nieuwe patienten leweren: dit geldt in sterke mate voor de ongehuwden (mannen en vrouwen resp. 23.49 en 29.17 pelt 1000) en voor de gescheidenen (mannen en wrouwen resp. 42.62 en 82.29 ). Voor wat betreft de gehuwde dertigers bestaat de zorg maar voor een kiein deel uit intramurale zorg (mamnen en vrouwen resp. 0.68 en 1.97 ), terwijl dit voor de engehuwden en de gescheidenen duidelijik anders ligt (ongehuw we mannen en viouwen resp. 6,78 en 4,02: gescheiden mannen en vrouwen resp. 7.61 en 20.92 per 1600).

Tenslotte bleck dat er weliswaar grote geografische ver. chillen met betrektking tot de hoogte van bell incidentie cinfer bestain. maar dan telkens dezelfde risicogroepen nase woren komen

\section{DISKUSSIE}

Enige woorzichtigheid bij het interpreteren van de resulla. ten is geboden, ondai de informatie gebasseterd is op de incidentiegevillen van een jarar en omdat enkele hategorieen (in de regiopoputatie en in de patientenpopulatie) kiein zijo ton er zodoende loevalstreffers in het material kunnen zitter. Dit laatste zou bijy. kummen gelden woor de gescheidem vrouwen boven de 80 jaar. Desondanks wijkit de hier gepresenteerde informatie nyet af wan de resulhaten wan andere onderzoekingen; telkens blijken er in grote lijnen dezelfde kategoriežn als 'geval' oververtegenwoordigd. warbij het ef theinelijk einig toe doet of de informatie werkregen wordt middels bevolkingsonderzock danwel met behulp van zogenaamd loketonderack. Een van de verschillen tussen beide vormen wan onderzoell vorm de gewalkdefinile: ain het lloketonderaok is a angemelde patient een geval terwifl in thet bevolkingsonderzock van een persoon informatie ominent het al dan niet geval zijo wordt verkregen met behulp wan unmiddels verfijnd ogende meetinstrumenten en onderzo ksdesigns. Daarbij lijkt het goed in herinnering tie brengen dat het instrument dat in het bewolkingsonderzoek het kriterium inzaka casents geeft (PSE: zie Verthey 1981 ) ankomstig is vanuit de (intramuirale) GOZ en daarin zhin validiteit vinet .

Onlangs verscheen er wanuit het zgn. regioprojekt in Nüme. gen (Hodiamont e, 1986) interessance informative betreflende de overeenkomsten en de Werschillen wussen psychosociale en prychuatrische gevallen. Eent dergetijk onderscheid maar soont gevallen is met behuip van een psychiatrisch case register niet te maken. Dit is dan ook de reden warom er door ons een onderscheid gemaakt is natar soont zorg die in 198 l ontwangen werd: wij veronderswellien dasrbij dat de intramurale zorg wrijwel exclusief bestemd is voor die patiémien die als een psychiatrische case an te merken ziln en dat in de extramurale zorg cen menging abaw tzig zal xijn van psychosociale en psychiatrische gevallen. En dan blijkt in het algemen, dat indien cen kategone intramuraa! als risikogroep naar woren komt, dit ook exuramurant het geval is. Uitzonderingen in dit patiroon komen zeker voor: met name voor de - vooral de jongere - mensen in de weduwstaat, die veel extramuraal en weinig intramuratil in behandeling versehijnen en voor de ongehtrwde mannen waarwoor het tegenowergestelde patroon geldt: Hodiamonit e.a. (1986) wonden dat van alle psychiatrische gevallen bijna driekwart cok en psychosociaal greval was: wij konstaleren dat extramuraal (psychiarrische en psychosocialle gevallen) en intramurasl (psychistrische gevallen) dezelfde bevolking gsgroepen alls risikogroepen naw vorem komen.

Vanuit een momentopnane, zoals die hier gepresenteerd is; kan uiteraard geen causale interpretatie gedestilleerd worden. Desondanks bijijkt wel dat de gekonstateer de trisikowolle momenten (fervof situsties) in en mensenleven korresponderen met enkete theoriefragmenten. Enerzijds zijn er in een thensenleven perioden met verhoogde risico's, zoals aan het begin van de volwassen levensfase en tijdens het semium. Anderzijus zou een analoog model an dat van Brown en Harris (1978) gehanteerd kunnen wor. den: personen die geen bevredigende en langdurige relatie mel eem ander apgebouwd hebben - en deze zullen nververtegenwoordigd $z$ ijn in de niet -gehuwden kategonieen - missea een beschermde faktor. Bowendien zullen in deze zelfde kategorieen de personen oververiegenwoordigd xijn die (recent) een belamgrijke gebeurtenis als "provoking agent' meegematst bebben. Beide theoriefragmenten villen elkaar aan en verschaffen zodoende wen interpret ta thek dier a wan het thier gepretenteerde material.

Het nadeel van laketonderzoek is dat mogelink causale relaties niet rechtstrek ks teggen zijn: de whate in how verne sociale faktoren een bijdrage leweren aan hetomista an van psychische stoomisisen wal middeis andersoortip onderzoek opgelost moeten worden. De pogingen daturtod (o. a. Hemderson 1981 ij zin prijzenswatardig. matr de resul. taten daarwam kunnen vertekend zijn: wit ondat het indvidu in een dergelijk onderzoek vian zijn socianal kullurele matr vooral van zijn historische kontext geisoleterd bezen wordi.

Tensiloite kar de vradgesteld worden of. indier zo konsis teni telkerili dezelfde risicogrocpen naar voren komen

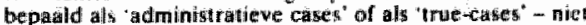
gekonkludeerd mag womden. dat de administratief bepalalde incidentie een goede verhoudingsmat is voor de geeste lijke gezondheid vian (sub)populaties onder voorwataf de dat

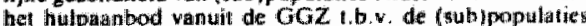
dezelfde is (De Vries en Hamers 19424: De Vries a a 1986 ) Echter alleen al door de faktor afstand is het hulpoantod - 


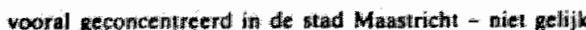
wor de getwele regio-populatie. Er mag wanut de gepiesenverdie informatle niel gekonkludeerid worden dat in de populatie win een (grolere) stad meer psychische hoomis-

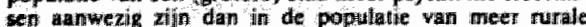
gebieden (athoewel dit op andere gronden warschiniffik its).

Vison de afzonderlyke buturten wan Manstrich kan an de voorwatarde van een getijl hulpaanbod voldan worden, omdat zodoende voor afstand gekontroleerd wordt Ondanis dat bijket dan dat de adninistratieve incidenticcijfers grose yerachillen te zien geven tusisen de burten en komen et telkens - of die buint nu een boog of een latag incidentieciffer kent - dezelfute ristcogroepen nas voren.

\section{NoOr}

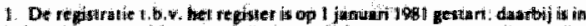

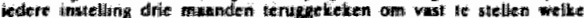

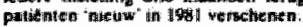

\section{SIMMARY}

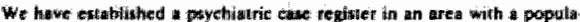

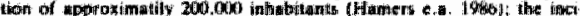

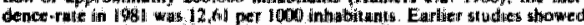

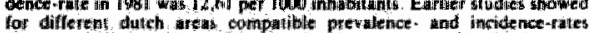

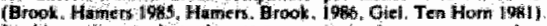

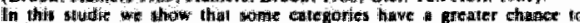

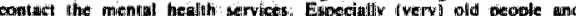

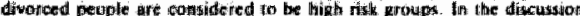

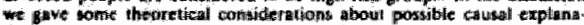
thon:

\section{LTHRATUEN}

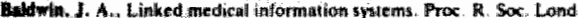
184 (11973) $4(49420$

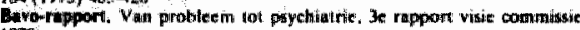
197 :

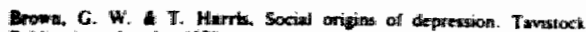

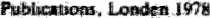

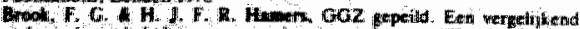

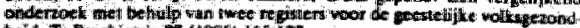

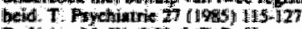

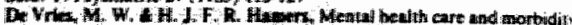

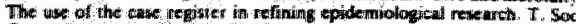

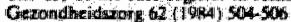

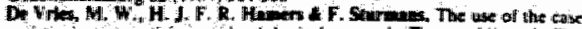

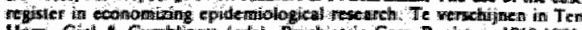

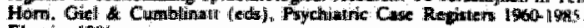
Eleveries 197 tho

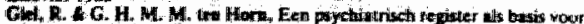

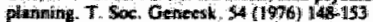

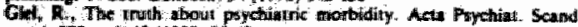

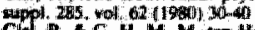

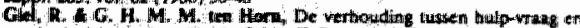

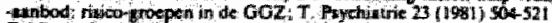

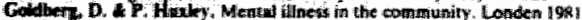

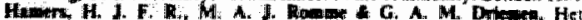

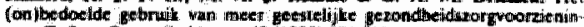

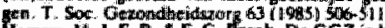

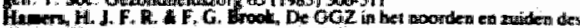

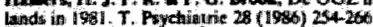

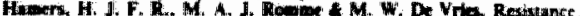

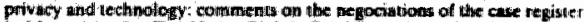

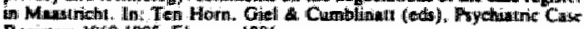

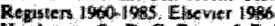

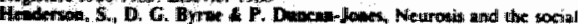

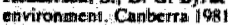

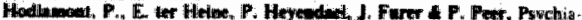

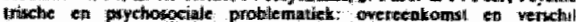

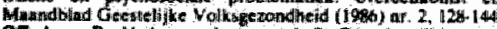

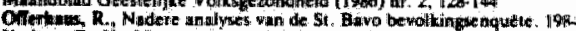

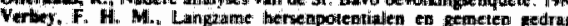
Leiter-Nypets; Mmastricht 1981

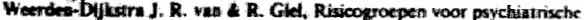
opmane. T. Pyychialic it (1975) 41-47

\section{CORRESPONDENTIEADRES}

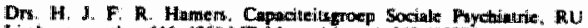

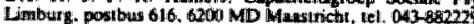




\subsection{Samenvatting}

In dit hoofdstuk is de GGZ in een zuidelijke reglo (ongeveer 200.000 inwoners) vergeleken met die in een noordelijke regio, bestaand ult een gemeente (ongeveer 45.000 inwoners). Global genomen bleken er in het zuiden meer patienten per 1000 inwoners $1 \mathrm{n}$ behandeling dan in het noorden: zeker indien wij bedenken dat de zuldelijke ciffers met $12 \%$ (de "weigeraars"; zie ook hoofdstuk 6) vermeerderd dient te worden. Het blijkt dat met name de extramurale GGz in het zuiden meer patienten heeft dan de noordelijke GGZ, terwijl de intramurale zorg in beide regio"s ongeveer evenveel patienten (per 1000 van de bevolking) in behandeling heeft. De semimurale zorg, die in belde regio's klein is, blijkt in het zuiden ongeveer twee keer zo groot als in het noorden. Wat het totaal antal patienten in zorg betreft moet nog opgemerkt worden, dat de zuidelijke reglo voor de helft uit ruraal en suburbaan gebied bestaat (war in het algemeen de in behandeling zijnde populatie kleiner blijkt) en de noordelijke regio wit eén ( $z i j$ het tamelijk kleine) stad bestaat. In het algemeen kan voorzichtig geconcludeerd worden, dat de consumptie an (algemene) gezondheidszorg in de zuidelijke reglo hoog is, terwijl ook de gezondheidstoestand van de zuidelijke populatie slechter dan elders $1 \mathrm{ijkt}$.

De resultaten beziend, mag geconcludeerd worden dat or in het zuiden meer personen bif de GGZ in behandeling zijn dan in het noorden: deze constatering wordt onderbouwd door de anwezigheld van een relatief Broot aanbod aan extramurale GGZ (zie Ypema \& de Haen, 1983).

Bekljken wij de verdeling over de voorzleningen, dan blifkt -indien onze blik globaal blijft- een grote mate van gelljkenis tussen beide GGZ-systemen: echter een meer gedetailleerde blik leert dat er kennelijk ook functies in de GGZ aanwezig zijn die door verschillende voorzieningen vervuld kunnen worden. Daarbif is 0. a. te denken a de relatief grote zuldelijke RAAZ-polikliniek en de relatief kleine zufdelifke APz-poli, maar ook aan een verschuiving tussen de zuidelijke bedden in APZ en PAAZ nat bedden in het crisiscentrum (een voorziening die in het noorden niet aanwezig is) en in de psycho-gerlatrische verpleegkilniek.

Ook werd geconstateerd dat categorieun - samengesteld op grond van demografische kenmerken- in belde reglo's oen even grote (of even kleine) kans hebben met de GGZ in contact te komen. Dit bleek, indien vergelifkingen tussen beide reglstergebieden gemakt werden $n$.a. v. de punt- en de Jaarprevalentieteling; oootgelijke bevindingen werden gevonden tijdens een studie (paragraaf 7.2.3.), die ten dele als een replicatiestudie te beschouwen is en warin incldentlegevallen onderwerp van studie waren. Hoewel langzaaman duldelljk werd dat generalisaties in globale zin meer mogelijk waren dan men aanvankelljk dacht, moet ervoor gevaarschuwd worden, dat de gepresenteerde informatle in sterke mate afhankelijk is van de GGz zelf en de darin vastliggende methodleken, opvattingen en administratieve gewoonten. 
Relateren $1 \mathrm{j}$ onze bevtndingen an de hypothesen zoals die in hoofdstuk 5 geformuleerd zijn, dan moet geconcludeerd worden dat de verschilen in de rulmte niet zo groot zifn en war a anwezig of terug te voeren zijn tot een verschll in anbod, of van doen hebben met een wiseling tussen voorzlentagen vat betreft vergelljkbare functies of een uitdrukk1ng $21 \mathrm{Jn}$ van de omvang van het abnbod. Een mogeligk punt van verschil heb $1 k$ in hoofdstuk 5 nlet voorspeld: namelijk een verschil wat betreft het punt warop een GGZ-syateem zich in haar ontwikeling bevindt. Bifvoorbeeld: al gerulme tijd is men in Nederland doende tot een 24-uurs berelkbaarheid in de GGZ te komen met al dan niet daaraan gekoppeld een crisisvoorziening var mensen kortdurend opgenomen kunnen worden. Het (toevallige) felt dat dergelifke voorzleningen in het zuiden (in 1981) reeds asnwezig waren on in het noorden niet, had enkele opmerkelfjke verschilien tot gevolg.

Concreet betekent dit dat de hypothese $1 \mathrm{t} / \mathrm{m} 4 \mathrm{zoals}$ die in hoofdstuk 5 Beformuleerd werden niet zonder de nodige anvullingen en nuanceringen geaccepteerd kunnem vorden. Hieronder zal ik dit meer in deta 11 beargumenteren.

De eerste te toetsen hypothese werd als volgt geformuleerd: de GGZ in twee regio's zal hetzelfde antal personen (op een tijdstip, gedurende 6én jaar en als nleuwe patiknten per jaar) in behandeling hebben." Daarbij zij er nogmaals op gewezen dat het hier twee specifleke regio"s -namelijk een middelgrote gemeente in het noorden van Nederland en de reglo zuidelijk zuid-Limburg- betreft. Op én tijdstip bleken or in het Noorden 7.59 per 1000 inwoners als patient bif de GGZ in behandeling en in thet zuiden 8.13 per 1000 inwoners. Op jaarbasis -d.w.z. als jaarprevalentiecijfer-bleken er in het noorden 24.25 per 1000 in behandeling en in het zulden 25.27 . Het zuldelijk incidentieclffer (1981) bleek 12.61 per 1000 fnwoners en ls daarmee hoger dan het eerder gepubliceerde noordelijke incidentieciffer (Giel \& ten Horn, 1981; zij geven an, dat gemiddeld per jaar van ledere 1000 inwoners van de noordelijke registerregio er in de periode 1974-1978 10.5 patient in de GGZ wordt).

Echter het zuiden heeft een 'welgerpercentage' (zie ook 6.2.2), het noorden niet. Wat betreft de prevalentleciffers ontstaan dan voor het zuiden respectlevelijk het noorden de volgende warden: 9.11 (puntprevalentle) en 28.30 (jaarprevalentie) en 7.59 en 24.29 per 1000 inwoners. Het blijkt dan dat in het zuiden meer patibnten bij de GGZ in behandeling zijn en komen (met een incidentieciffer van 14.1 tegenover 10.5 per 1000 inwoners).

De eerste hypothese in de hierboven geformuleerde vorm dient verworpen te worden; toetsing van de tweede kan ons leren hoe de certe hypothese geherformuleerd dient te worden. Deze tweede hypothese luldt als volgt: "de verdeling per reglo van patienten over de echelons zal enzelfde beeld tomen."

Uit de punt- en jaarprevalentieteling blijkt dat deze hypothese niet te verwerpen 1a, alhoewel er klefne verschulvingen te zien $21 j n$, 
warbij de zuidelifke semimurale sector lets omvangrifker is dan de noordelijke. Ook uit de antallen per 1000 is af te lelden dat voor alle chelons in het zuiden geldt (zeker indien de 'velgerars' meegerekend worden) dat zif meer patisnten zien dan in het noorden: dit gat echter vooral op voor de extramurale cGz.

Uit de bespreking tot nu toe kan geconcludeerd vorden, dat de bevinding dat het zulden meer patidnten (per 1000) in behandeling heeft, vooral is toe te schrijven an een groter antal patiditen ambulant in behandeling en in wat mindere mate asn patidnten die semimuraal met de zuidelifke GGZ in aanraking kwamen.

De derde hypothese "de verdeling per reglo van de patignten over de afzonderlijke GGZ-voorzieningen zal eenzelfde beeld tonen", kan masr zeer ten dele geaccepteerd vorden. Immers er blijken een aantal verschuivingen te constateren: zo is de noordelijke APZ-poll groot en de zuldelijke klein, terwijl dit voor de PAAZ-poli's julst andersom ligt. Intramural zijn er verschillen te constateren, waarblj het zuldelifk crisiscentrum (in het noorden afwezig) en de zuldelljke verpleegkliniek veel patienten in verhouding tot die voorzleningen im het noorden hebben, terwijl dit voor APZ-en en PAAZ-en weer precies andersom geldt. Het $11 \mathrm{jkt}$ er sterk op dat het zinnig is te denken in termen van noodzakelijke functies in plaats van noodzakelijke voorzieningen: zo 1 ifkt het uit de vergelijkingen noodzakelijk dat er bifvoorbeeld (kortdurende) opnames plaatsvinden, maar dat die nlet perse allemal in een APZ of PAAZ gerealiseerd behoeven te worden. Ook blijkt er behoefte aan een meer medisch (-psychiatrisch) georienteerde ambulante voorziening, mar die kan in wiselende verhoudingen vervuld worden door GGZ-voorzieningen als APZ- en PAAZpolikifniek en door vrijgevestigde zenuwartsen.

Tenslotte kan hypothese 4, mde verdeling per reglo van de patibnten naar demografische kenmerken zal eenzelfde beeld tonen" als geaccepteerd beschouwd worden onder a antekening dat er in het zuiden minder jongeren in de GGZ geregistreerd zijn dan in het noorden. Daaruit mag. nlet zonder meer geconcludeerd worden, dat or in het zuiden lacunes: op het punt van de jeugdzorg zouden zijn, ondat ook therapeutische ulgangspunten en daaruit voortkomende administratieve gewoonten (met name in de zuidelijke RIAGG) een rol blijken te spelen. 
HOOFDSTUK 8

\section{DE GGZ ALS ORGAMISATIE}

\subsection{Inleiding}

Als een organisatie - of een groep nauw verbonden organisatiespretenteert goed te functioneren, dan is het minimal noodzakelifk dat geconstateerd kan worden dat $z i j$ doet wat $z$ if voorgeeft te doen. Zo acht men het opportuun om tot een optimale afsterming te komen tussen de GGZ-voorzleningen: m.a.w. men tracht de voorzieningen dusdanig te doen functioneren dat voor de verwijzer en de (potentiele) patient duidelijk is voor welke kwal en welke daarbij in anmerking komende behandeling men war terecht kan. Danwel men formuleert tussen de voorzieningen zodanige afspraken, samenwerkingsverbanden en overlegstructuren dat de juiste patient op de juiste plek terecht komt en dat deze daarbij zo min mogelijk stations dient te passeren.

\subsection{De mate van afatenming in de GGZ}

In deze paragraaf zal ik enkele concrete probleemstellingen formuleren welke in dit hoofdstuk vervolgens behandeld zullen worden. De GGZ in Nederland wordt nogal eens vergeleken met een lappendeken en men verwijt har daarbij een onoverzichtelifke atructur te hebben: in hoofdstuk 4 heb ik laten zien dat deze situatie goeddeels historisch zo tot stand il gekomen, mar van de andere kant van doen heeft met de wens GGZ-behandelingen, voldoende gedifferentieerd an te bieden. Echter ook heb $1 k$ al aangegeven dat het overheldsbeleid sturend anwezig wil zijn en verwacht moet worden dat deze sturing -en de anticipatie daarop door de regionale GGz- gevolgen zal hebben.

In hoofdstuk 7 constateerden wij dat het antal patienten in contact met meer dan 6én GGZ-roorziening groot is: dit bleek bovendien" in twee reglo's en er is geen reden te veronderstelien dat dit 'multiple-service-use' in de rest van Nederland minder zal zijn. De vraag hier is dan ook hoe de GGZ beleldsmatig omgat met dit gebrulk van meer voorzieningen. Daarover handelt paragraaf 8.2 .1 , een reeds eerder gepubliceerd artikel met als titel "het (on)bedoelde gebrulk van meer GGZ-voorzleningen".

De tweede vraagstelling in dit hoofdstuk komt voort ult de navolgende constatering. Gedurende de latste decennia blifkt het antal eerste psychiatrische opmamen en in nog aterkere mate het antal heropnamen in het APZ sterk te zijn toegenomen: daarbij is de gemiddelde opnameduur sterk bekort. Door de atijging van het antal kortdurende opnamen in het APZ -en daar de opnamen in de EAAZ bijna per definitle kortdurend zijn- lijken beide voorzieningen eenzelfde functie te 
verzorgen. De vrag is dan: wasin verschllt de kortopgenomen patillit In de PAAZ van die in het APZ?

B11 belde vraggtellingen is het van belang on aan te geven in hoeverre er zich t.a.v. deze punten veranderingen in de t $1 \mathrm{~d}$ hebben voorgedan. 


\title{
HET (ON)BEDOELDE GEBRUIK VAN MEER GEESTELIJKE GEZONDHEIDS- ZORGVOORZIENINGEN
}

\author{
H.J.F. Hatiners, M. A. J. Romme, G. Driessen

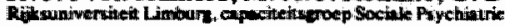

Van de patiënten, die bij de geestelijke gezondheidszorg (GGZorg) in behandeling zijn, blijkt een grote groep gedurende een relatief korte periode met meer GGZorg-woorzieningen in aaniraking te komen. Ten aanzien van dît gegeven kunnen twee vragen gesteld worden. Namelijk in hoeverre: 1. bestaan er samenverkingsverbanden of overlegwormen tussen die GGZorg-voorzieningen waar dit saort overlap aanwezig is en

2. is het terecht dat dit gebruik van meer GGZorg-voorzieningen plaatsvindr?

Het onderzoek in de regio Maastrichr - uitgevoerd met behulp wan een register woor de GGZorgbracht aan het licht, dat her overgrote deel van de overlap tussen de voorzieningen gedekt werd door samenwerkingsverbanden. Dit in tegenstelling tor de resultaten wan een eerder registeranderzoek (Ten Horn en Giel, 1978) in een andere regio; in die publikatie werd gepleit voar meer overleg ook russen die GGZorg-voorzieningen welke geen organisatorische eenheden vormen.

Ook ten aanzien van de patronen tussen de voorzieningen werden op enkele onderdelen afwikingen gekonstateerd in vergelijking mer het eerder onderzoek. Dit kon verklaard worden wit het gegeven. dat de regio Maastricht in 1981 eem krisiscircuit kende; eendergellike voorziening was in het andere registergebied niet aanwezig.

\section{INLEIDING}

Zoals de titel suggereen zall in dit artikel wonden ingegaan op de vraag. wanneer - uiligatande van ee a optimale afstem ming van de zorg op de moden van patienten - het gebnitk van meer geestelijke gezondheidstore (GGZorg) voor zieniagen functioneel danwel dysfunctioneel is. Aan de hand van gegevens uit hell Register woor de Geestelijke Gezondheidszong in Maastricht e.o. (die regio zuidelijk Zuid-Limburg) wordi nagegaan welke vormen van multiple-service-use' zoal woorkomen en dasitbij wordi ter discussie gesteld wat hiervan alls warrchijnijik juist gebruilk en wat als mogelitk onjuist gebnilk kan worden angem merki.

De geestelije gezondheidszorg in Nederland wordt nopal ews vergeleken met weri kappendeken en men werwiji has dastbij een onoverzichielithe stinuktuur te hebben. Ten dele is deze knitiek terecht en mede dnarom lijkt het verstandis (overheids)belleid enige struktuit on samenhang an te brengen, Daanoe werden Regionale Instellingen voor de Ambulante Geestlijke Gezond heids zorg (Riages's) tot stand gebrach. wardocor een groot deel van het ambulante veld samengevoegd werd. Momenteel zijn er in vele regio's oolk Regionale Instellingen voor de Geestelijkie Gexand heids. zorg ( $\mathrm{Rig}^{4}$ 's) opgezet or in voortbereiding, wharin het ambulante veld en de belangrijkste intramurale voorzieningen onder even bestuurlike noemer worden gebrach.

Ondanks deze posillieve ontwikkelingen moet gekonstateerd worden dat de hulpwertening (zeer) gedecentraliseerd en autonoom plaalsvindt, waarbij bovendiem door iedere hulpwerieningsvorm min of meer specifiehe behandelingsvormen tea behoeve wain min of meer omschmeven doelgroepen wonden geboden.

Brook en Hamers konstateenden voor twee gebieden - bet woondelijlk en thet zuidelijk registergebied met respectient- lijk 45.000 en 200.000 inwoners - dat een growt deet van de patienten, die op een peildatuim met de GGZorg in kontak! stondien, rond die peildaum (gedurende zes manden) bij meer voorzieningen in behandeling was; n.I. rond de $15 \%$ (Brook en Hamers 1985). Van alle palienien die gedurende een jaar met tenminste een GOZorg-voorziening in kontakt kwamen, bleek de groep mulniple-service-users mog groter (Hamers en Brook 1985). Deze messultaten sporen met de untkomsten wan vooegere onderzoekungen. die met behulp van een register weinden uingevoerd (zie b. v. ten Horn en Giel 1978 ).

In de literatum wond valk geswigereerd dat muliple service-use gedurende een konte periode als negathef beschouwd dientle wonden en suggest te die door wele

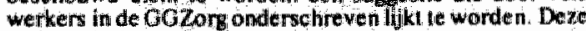
suggestie word bovendien vaht gehoppeld an de onover-

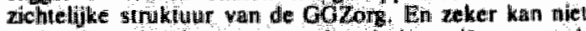
ontkend wonden dal met mame chmonisehe patienten - waak langdurig, ambulknt in behandeling met daprtus sendoo $\mathrm{kll}$ nische behandelingen - soms op een zeer wilkekeurige minier GGZorg konsumeren het \& g. shopping-around van deze growep wordit zelfs als can van de kenmertken van chroniciteil ge roend (zie b. Whotuevell 1984 ).

Toch is er in de literatuur oolk en positieve opvalting anwezig ten aanzien van het multiple-service-uste ex opvating die onder het begriph hontinuilieit van zorg te vangen is. Kontinuinteil van zorg ontstast als probleem of het moment, dat de hulpwerlening om welke reden dan ooh niel meer door es nulpverlener (of tewh/ardelling) gebodem wordit. Om de konthuiteit wan zong te warborgen ont staal het in de tijd opeenwolgend of het gelijkt id ig gebruik maken van mier GCZorg-voorziethingen. Voor de Nederlandse

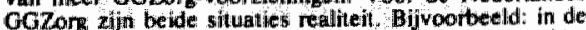
tid opeenvolgend biu nazor no onislag van een pisychia trisch bed. Deze nazorg wordt als belaingrijk beschouwid en 


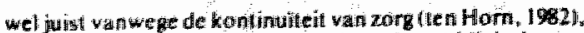
maar omdai nazong meesital nite de lavk van kliniseh werkende hulpverleners is. ontstad hel gebnuik vain meer GOZary-yoorzimingen lets deraelijks ireed took op. indien er ambulante kontakten als voorzorg plaausinden om een oprame le woorhomen en er alsnog een opname peindicee rd is

Voorbeclden wan gelijktijuig gebwik komen in de praktijk voor, wanneer een GCZOng woorziening wel de ente service kan bieden (bijv. psychotherapie of gezinsondersteuning). matar niel de anders: (bijw. sen vaor de patient zinvolle dagwulling). Indien hulpwerieners op een dergetijke wijze gebruil maken wan de diensten van andere voorzheningen utiteraard met als bedoelfing de behandeling van de paticnt 20 goed anogelijk, binnen cen zo natuuritily mogelijk dageliks leven toen werlopen - is er sprake van het gebruik van meer GGZ7org-voonieningen zonder dat iemand zich dmanower in negatieve zin zou kunnen uitlaten czle ook Romme $1962 \%$. Wij zouder ideze vorm van gelijklijdig gebruilk wan meer woorzieningen zelfs als een worm vian maal werk kunnen beschow wien. warabij de zorg door ver"* schillende GGZorg- voorzieningen inel verschillende funkties in gezamenligjkheid aangemeten word! (zie ook Rotueveel 1904 ).

\section{VRAAGSTELLINO}

Om te bezien in hoeverte thet gebruik wan meer GGZorgvoorzieningen als funktioneel danwel als oystunktionecl

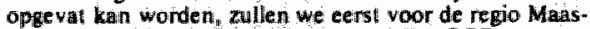
trich e.0. moeten wastsule lien mei welke GGZorg-voorzieningen de groep multiple-service-users in aarakimg kwam gedurende het onderzoeksjas.

Het onderscheiden van kombinaties van GGZorg-voorzieningen watrvan groepen patiènteta gedurende cén jaar gebruilk maken heefi tol doel na le gaan:

1) of er een relatie is thissien dit gebruik van meer voorzieningen en de afgesproken samenwerkingsvertoanden of overtegvormen in de regio:

2) of er gebruik van meer voorzieningen voorkomt tussen instellingen wast ij sprake is wan het bieden vam eenzelfde soor zorg " terw jil er geen sprake is vam taak verdelingsafspraken.

In het eerste geval wijst miltiple-service-use op functioneel gebruik, in het tweede gewal op dysfunctioneel gebruik. Vooir de beantwoonding van dere vraggstelling wondl aller. cerst de methouk beschrewen warmee he! gebruik van met Goizorg-woorziemingen door een patient is vastgesteld. Veryolgens zullen de belangrijkste same nwerkíngsafspraken in de regio us sen de versehillende voorzieningen worden weergege ven. Datma zal grafisch de omvang vian de zong in te divers voorzieningen worden weengegeven on het percentweet andeel wan de patienten die in bet onderzoeksuar $(1981)$ nog mat andere voorzieningen in konthkt stonden. Voor de groep multiple-service-users word teisslotle per voorztening aangegeven of dil oenvoudig verlklarard kan worden met behulp van de gemakte samenwerkingsafspraken, of dat dit nietl het geval is.

\section{METHODE}

Daar wif peutheresseend ain in hel gebruik van meer GOZorg voondienimgen zila wij voor onze infommatie an. gewezen op een psychinatrisch case register. Een dergelijk register, opgeztet naser analogte wan het negister in hel noonden wan Nedertartid (Giel en ten Hom 1976, a ook Wing 1972), bestaat simdis 1 januar 1981 voor de regio

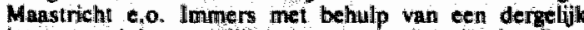
imstrument is het mogelijk (op grote schaal) pationtharments te rekonsitneren en paptientenstromen tussen de $00 \mathrm{Zorg}$ - voorzleningen te bepalen. Da: is mogelijk omdat de gegevens vani alle kontakten tussen de GC2org en de leden wan de populatie in eem omschre'ven Bebied op een cenitral punt bijerengebracht zijn en middels een wasschijnlijkheidskoppeling per patient aaneengekoppeld worden Deze war. schiljnlijkheidskoppeling geschied me: behulp van een beperkle set identilikalliegegevens tde woongemeente bij geboorte. de cerste lelter vam de geboorte-achternam en de geboontedatumil wandoor de priwacy gewarbongd is (zie ook Baldwin 1973).

Met behulp van dit register woor de GGZorg is voor de regio Masstricht de jaarprevalentie vasigesteld voor $198 \mathrm{I}$; d.w.Z. de groep patienten is bepaald die in de lowp van 1981 met tenminste een GGZorg-woorziening kontaki hadden (Hamers en Brook. 1985). Van deze groep van 4201 patienten, woonachtiog in de regio, bleek een groot gedeelte bij meer dayn een voorziening in etn jar tijd in behandeling le zij.jn $(19.7 \%)$. Alvorens het gebruik van meer voonzie ningen weer te geven zulten wij eerst de regionale GGZorg in de regio Maastricht e. 0 . bespnelhen.

\section{DE RECIONALE STTUATIE}

Er is cen breed spectrum aan intramurale, semimurale en extramunale GOZorg in de regio anwezig (zie ook Browk en Hamers, (985). De belangrujkste samenwerkingsverbanden worden vanuit de in de regio aanwezige behandelingsfundkties beschreven. Op die munier kan dan wordem aangegeven in hoeverre multiple-service-use als funkitoneel of dysfuniktioneel gezien moet worden.

\section{Aunbutante betiandeling}

Voor deze vorm van behandeling zijin een groot aantal GGZong voorzieningen aanwezig: de pollikliniclken (APZ en PAAZ), enkele vrigevestigde zenuwartsen en de Riagg De Riagg heeft l,b.v. de inierne organisatic metl haar rayon" teamis afgesproken dat deze voor alle soorten GOZ probilematiek een eerste onderzoek en behandeling bieden. echter niet langer dan gedurende een perinode van 6 maanden. Indien een langere behandeling getindiceend is, verwijzen zij dow maar de zogrenaarade centrale teams van de Ribag (de SPD-aldeling, de psychotherapit-afdeling, de afdeling Jewgdzorg en de afdeling Sociale Oeriarie). Dit betekent dait er tussen rayonteams en centrale teams in de tijd opeenwolgend multiple-service-use te verwachtea is.

De polliklinieken van een instelling (APZ en PAAZ) werken uliteraard samen mel andere afdelingenffunkties van de destbetrefferde inslelling ook diagr zal dus multiple-service-use voorkomen. Multiple-service-tise tussen de poilWilineken onderting en tussien de poliklinicken, de vrijgevestipde zenuwartisen en de Riggeteamis is, zeker als het gelifktijdig plastsvindt, dysfunktioncel te noemen. Dil temeer orndat deze GOZong voorzieningen in grote mate eenzelifde type beliardeling bieden.

\section{Sematimancle betandeling}

Bif deze hulpverleningsworm zijn een idrietall belangrijke onderscheidingen te maken.

De eervie is krisisinterventie. Dal geschied in muwe samenwerking tussen het Krisiscentrum - Nls semimumale voorziening waar mensen tijdelifk wonden opgevangen en ook kunnen ovemachten - en de 24-uurs Opvangpost. Deze batste voorziening werkt extramuraal en is peorganiseend om builten de kantooruren service te bieden bij takute psy. chiatrische en psychosocitale problemen m. b. $v$, mobiele bujpverteners die de persoon in de lkrisissituatic ook in zijn eigen milieu kunnen bezocken. Het is de bedoeling om dan alkute hulpvertening te bieden en zonodlig door te verwijizen 
naar de meest mapewezen (GCZorg of andersoortige) voorziening in de regio. Deze service is eveneens bestemo voor patienten die reeds met de GOZOMr in kontalkt stman. doch die bij akute kritses moten worden opgevangen (zie ook Hamers, 1983). Tussen Krisiscentum en 24-uurs Opvangpost is multiple-service-use met alle andere voordieningen te werwachien.

De tweede semimurale GGZarg-voorziening hebben wit in de presentatic wan de gegevens samengenomen onder de kategorie dagzikekenhulis; hieronder wallen een aantual dagbehandelings plaztsen ( 0.8 . dagkliniek) en dagst rukturerende aktiwiteiten (aktliveringsald el ingen), Organisatorisch is deze voorziening in het $A P Z$ ondergebrach.

Ten slotte zijn er nog de beschermende wopinvormen. Deze behandelingsworm is voor een deel organisitoriseh ondergebmacht binnen het APZ en woor een deel binnen de Riagg Het gebruilk van de semimurale woorrieningen ta van andere voorzieningen hang samen met verwijhingen vanuit de extramurale en de intramurale zorg en bovendiem met het annwezig zijn van lokale samenwerkingsvertanden: deze zullen nog apar besproken worden.

\section{Intrumiande behandeling}

De intramurale behandeling kan in de regio naar een drietal vormen onderscheiden worden; het APZ, de PAAZ en de psycho-geriatrische afdieliagen van de Verpleegkliniek.

Zoals overal in Nederland wondt naar deze behandelingsvormen verwezen door de gehele extramurale seixtor en de: krisis voorzieningen, tenwijl de PAAZ en hel APZ zullen verwijzen near semimurale voorzieningen en de VerpleegLeliniek.

Dit betiekent dat multiple-service-use wan de intramuralle woorziemingen thet alle andere woorzieningen verwacht. mag wonden. Ook tussen de intramurale voorzieningen verwachten wij multiple-service-use mede door aanwezige samenwerkingsvertanden waraan de intramurale GGZorg participeen.

Bovenstande beschriving van de GGZorg; in de regio Masistrich" behoeft nog een belangrijke aanvulling. omdat er een antal afspraken bestan binnen emkele lokate samenwertingsvertanden, wardoor voorieningen onderlings aan elkakar gelieend: zijn. Dil bneng1 nog wormen van multiple-service-use met zich die als funktionecl aan te merken zijin. De samenwerkings ventbanden kunnen onder de volgende noemers gebracht worden:

a. Het krisiscircuit" hiervoor verwachten wij multiple-ser vice-use met. alle GGZorg voorzieningen: dit komi rechi. streeks voort uit de regionale organisatic van de krisishulp als service buiten de kantooruren.

b. Het psycho-geriatrische circuit: binnen dit circuit wer-

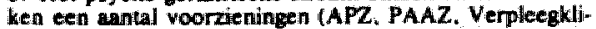
niek en de Social Geriatinische Dienst van de Riargit samen om tot een gezameniligk beleid ten aanzien van de doellgroep the komen. Multiple-service-use in deze sektor moet zeker als funktioneel gezien worden maar gezien de specifieks: propulatie verwachten wij niet dat hel om grote antallen gaat.

c. Het sociad-psychiatrisch circuit behellst een samenwerking tusisen een wan de centralle tearms van de Riagg (de: SPD-funktie), de beschermende woonwormen, hell dagziekenthuis (met name do dagaktivering). de APZ en de PAAZ-beddenafdelingen. Multiple-service-use, warbij deze voorzieningen zowel in de thjil opeenwolgend alsook gelifktijdig betrokken zijn, is vanuil dit samenwerkingsverband als funktioned aan te merhen.

d. De PAAZ als service-instelling ten behoeve van hell $A P Z$ betreffende de patienten, werdach van organische afwitkingen. waarvoor nader somatisch oderscheid geindiceerd is. Hienwoor lent zeb Algemeen Zekenhuís meer de overgeng van APL naw de PAAZ (en omgekend) mag dan ooli zelker terwach worden.

c. Ten slotie hebben wili wolk ender angegeven dtal er binnen een instelling tussen de vernschillende funktitest. verschillende woorzieningen - samengewerkt wondt. Deze sameawerlsing wordt door ons als funktioneel gezwen

\section{RTSUTATEN}

In fuguur l is het gebuik van de intmamumle en semimunale voorzieningen weergegeven, onderverdecld nawir hel percentage alleengebriti" (niel searceerd) an gebnuik wan andere woorzieningen (geanceerd), d w, z het asindeel wan mensen die in het jar van onderzoek tewens kontaki mel andere voorzieningen hebben gethad

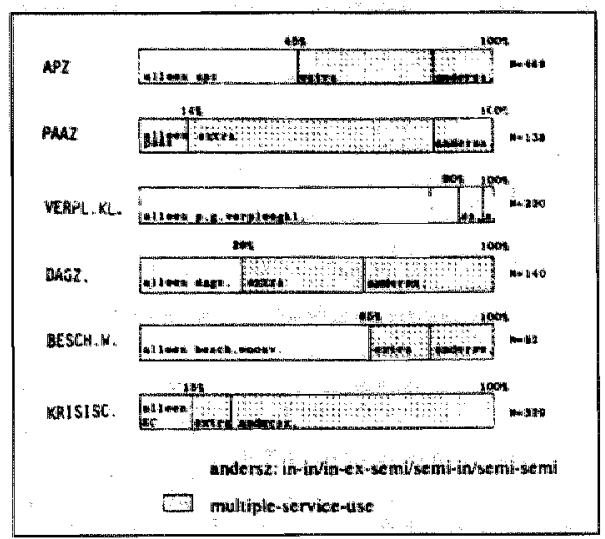

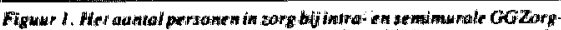

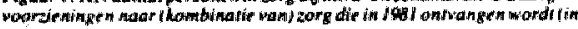
Pefremages i

Het gebruik wan meer voorzieninger woor de patientenpopulative wain het APZ is $55 \%$, van de PAAZ $86 \%$, van die verpleegk liniek $10 \%$, van thel dagzickenthuis $75 \%$, van de beschermende woonvermete $35 \%$ en van her Krisiscentrum 85\%. Naarmute de gemiddelde verblifisduur tin do destbe treffende voondeningl korter is, ligt hel percientage patienten dat lewens van een andere voorzleming gobnulk matakt hoger. Dil is to verwachien. gezien het foit dat iemand zelden in exen intra of semimurale voorztening opgenomen of onislagen word" zonder dat er, voor die opname of ma hell onitstige ambullarite kontakten met een GCZongvoorzic ning plats winden.

In figuur 2 wond hetzelfide weergegeven, maar dau voor de exiramunale voorzieningen.

De percentages multiple-service-use liggen, met uitzondering wan de 24-uurs Opwangposi. bil de exiramurale vooriaeningen aanzienlijik lager dan bij de intra- en semimurale zorg. Het hoogste pencentage multiplle-service-users: ziein wiil bij de 24-uiurs Opvangposi (77\%). Vervolgens bif de pollikiniel van het $A P Z\left(40^{\circ} \%\right.$ ) de polikliniel van de $P A A Z$ en de centrale teams van die Riage (beide $29 \%$ ) en tensloute de vrigevestigde zenuwartsen (17\%) en de rayonieams wan de Riagg $(14 \%)$.

Deze re latief lage percentages zijn ook te verwachten woor de extranunale GOZ 0 mg voorzieningen fuitgezonderd woor de 24-uurs Opwangpost). Wel mont bedacht worden dat het in absolutie aanialien om grote groepen klituten gan. De rayonteams van de Ringog levenem in absolute tiantallen 


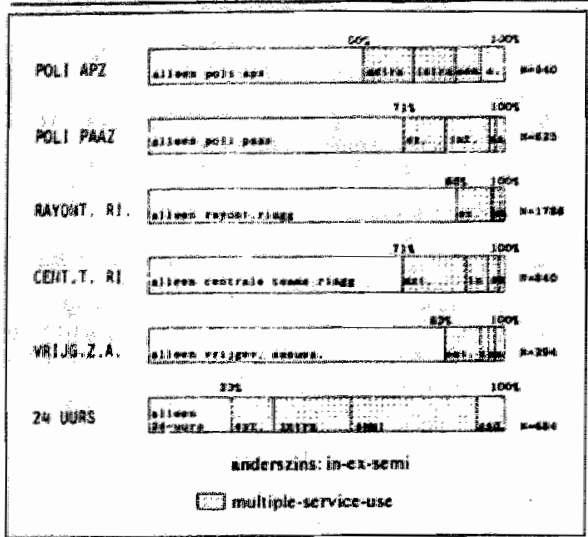

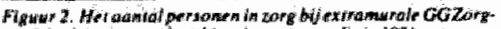

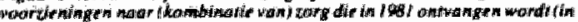
perternages?

meer multiple-service-tsers op dasn de polikliniek van bet APZ (250 tegenover 216\%. Datzelfore geldi woor de cenirate leams wan de Rians, in vergelijking met de poliklinick vas het $A P Z$ (243 thegenover 216).

Figuur 3 geeft woor de multiple-service-users weer in welk percentage tevens van eef van de andere met navam genoemile voorzieningen gebruik is gemaikt dastin milgaande van thet totatall aantal multiple-service-users per instelling. In ledene horizontale balk komen dubbeltellingen voor van diegenen die met meer dan twee voorzieningen (3 en meer) in kontakt komen. De lengte wan iedene balk als overschrijting wan de $100 \%$ onenis is dus een indicatie voor de mate van ditiedubbel ten meerl gebruilk van de GCZorg voorzieningen.

In figuur 3 is aangegeven welk ded wan het multipleservice use vanuit de eerder beschreven samenwerkingsivertominden door ons als funktioneel wondl ge zien. Daarbiji is telkens voor ieder blokje multiple-service-use aangegeven met welke regionale afspraken wij te maken hebben. Het is opwallend dat er woor de intria/semimurale sekoor marweliks vormen wan dysfunkitoneel muldiple-service-use te

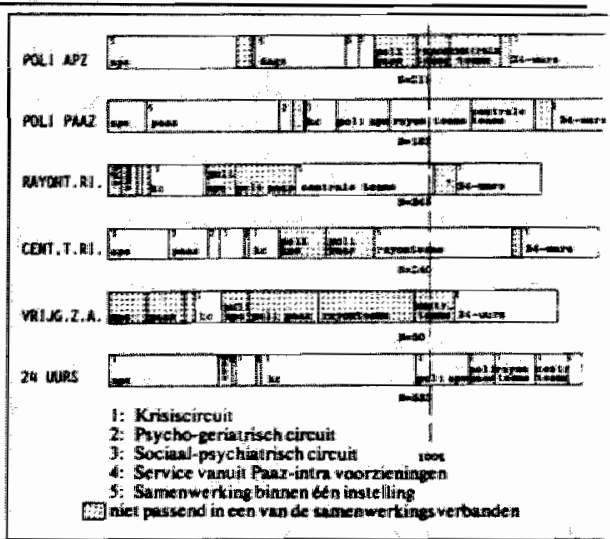

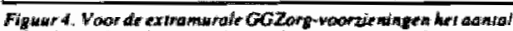

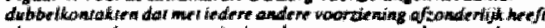

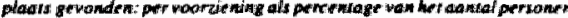

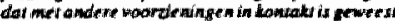

konstateren zijin. Tevens is het opvallend dat de 24-uurs Opwangfossl mel alle voorzieningen in deze sektor een duidelijke overlap te zien geefl; met name geldt dit voor de kombinatie van APZ en 24-uturs Opvangpost.

In figuur 4 is hetzellide weerge gewen als in figurur 3 , maar nu voor de exiramurale GOZorg-voorzieningen.

Redenerend vanuit onze opzet is er nogal dysfunktioneel multiple-service-use in de extramurale sektor te onderscheiden. Vooral de overtap tussen de polikliniciken onderling en tussen de poliklinicken en de Ringr-teams springt in het $00 \mathrm{~g} ; 00 \mathrm{k}$ al gezien de grote aantalien kijenten waar bet om gant.

Uireraard is cen deel van de overtap tussen de poliklinieken en de writisevestigde zenuwartsen eneraids en de Riageteams anderzijds wel te verklaren, indien verwijzingen vanuaht de eersten nar de laatsten plaatsvinden.

Het blijkt echier moeilijk om te bepalen wanneer een patient overgaal van de ene instelling magr de andere. omdat een grote varueteil in patientenkamtnes anwezig is. Soms heeft cen patient enkele kontakten met een andene GOZork-voorziening, waarna de behandeling weer word

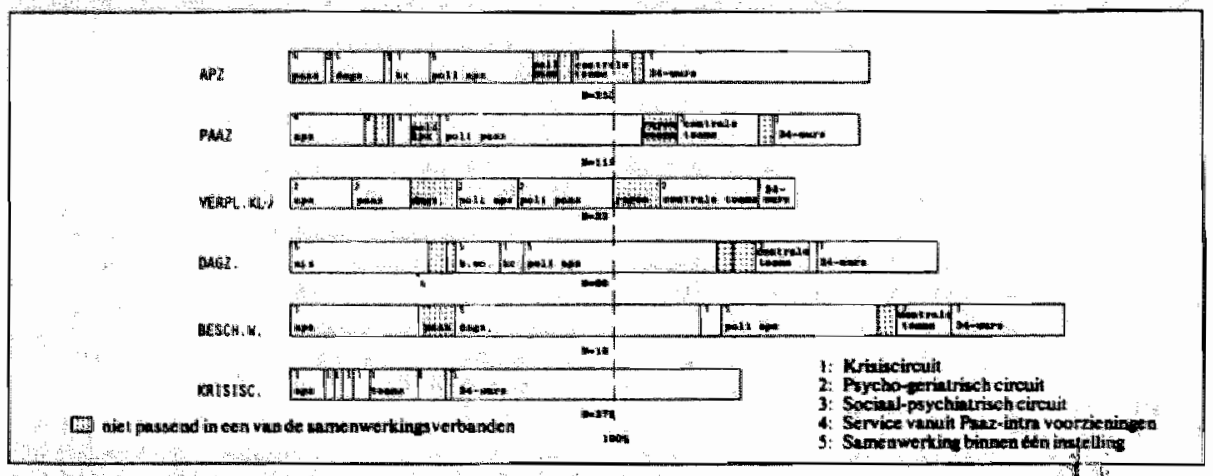

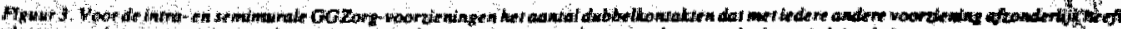

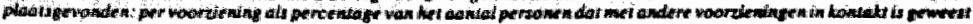


voortgezet biji de oorspronkelijke voorriening. Soms lkom! de verandering van de ene extramurale voorziening nawr de andere tot gitand, hadal er een intrz- of een semimurate behandeliag plasts heef gevonden. Tenslotte komen erook gelijktijdige behandelingen woor warbij in hell algemeen de Kontaktfrequentic bij de the voorziening hoos en bij de andere voorzening lage is. Helt zou in dit kauder te ver voeren deze zorgpatronen gedetailleend te bespreken: wel willen wij hiserover bianenkon rapponenen waarbij de zorg zoals die dow de patienten gekonsumeend wondt central zal stas.n.

In de latste fiztur zin voor de grootste GOZZorg-voorzieningen de onderlinge petientenstmomen weergegevein. Daartoe is van alle patienten, die gedurende 198 I mel meer dan cen voorziening in kontalikt kwamen, de voorziening bepaald warbij men in 1981 het eerst in behsondeling was. Zo vertrokken er bj voorbeeld 89 patienten vamuit de rayon-teams nar de centrale teams (dít is dus cen patifntenstroom binnen een instelling. maar tussen verschillende (GZong-voorzieningen); omgekeend hadden 13 patienten met een van de centrale teams het eerste kontakt in $\mid 981$ en vertrokken vervolgens richting rayonteam.

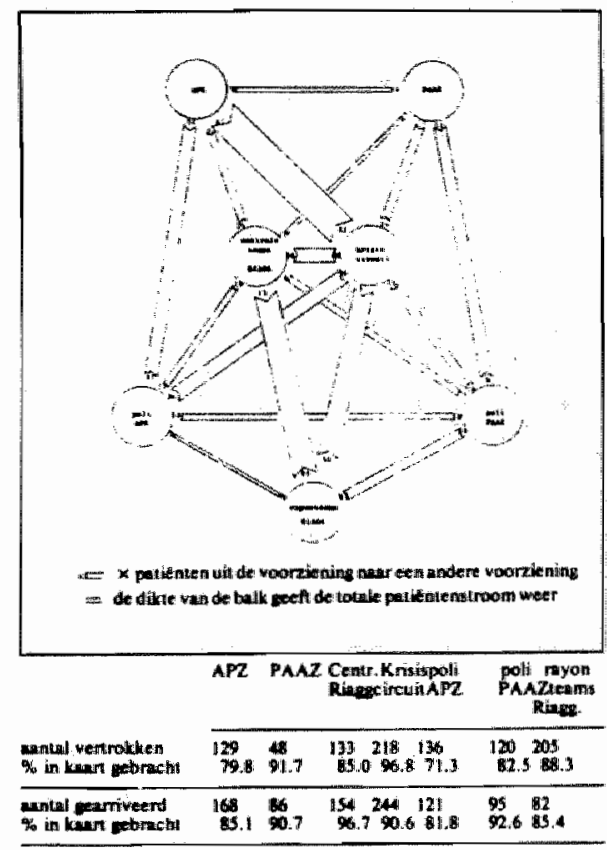

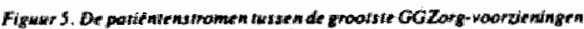

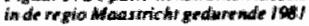

De dikte van de verbindingsbalken in de figuri geeft het totaal aantal patienten weer die bij het onderling verkeer tussen twee woorzieningen betroklken zijn. De meest omvangajike patientenstromen komen en gaan vanuit het zogenaamde krisiscircult (het Krisiscenirum en de 24-uurs Opwangpost zijin daarin samen genomen). waarbij voonal het verkeer met het APZ omvangrijk blijkt.

Een anxiere omwangritike stroom loopt tussen de rayonteams en de centrale teams van de Rlags. De patientenstro- men tusisen de extramurale en de intramurale GOZorg. voorzeningen lopen vamuit de pwoliklinieken van de PAAZ en het APZ en de centrale tegints wan de Riags Datbil wormen zowel the APZ alsook de PAAZ ieder een didiclijk organisatorisch blok, tenwifl de patidentem wan de centrale teams wan de Riagg werdeclid worden over het APZ en de $P A A Z$, Wanuit de intranurale sektor gaan weinig patiè nten riehting centrale teams van de Riage in werhouding tot het aqual dal richting poliklinieken gaal. Vergeluken wu deze fuguur 5 met enkele resultaten zoals idie nas ande id in wan vroeger registeronderzoek geputbliceend werden (Ten Horn en Ghel 1978 \%, den valt hel voondle regio Masalricht op dal het knsiscireuit en belangrijke funkt tic vervui!: en dai zowel voondat cen opname platisvindill alsook nadat een opname betindigd is. Deze voorziening was in het dow Ten Horm en Giel onderzocht GGZong-systcem niet aainwezig. Ten Hom en Giel honden vastsiellen "dat PAAZ en APZ ieder woor zich tesamen met de eigen polikliniek duidellijk organisatorische etnheden vormen. Eenzelfde konkhusie kan ook nu getrokkis worden, zij het dat potiènte nstromen binnen deze eenheden kleimer zijin daarvoor in de plants zijn de patiëntenst romen wamuati de ext mamu ralle voorzieningen maar hel krisiscircuil ten vanuti het krtigiscifeuil naar het APZ en de PAAZ gekomen.

Wu zagen zojuist dat de Riags maar weing patienten (terugkontvangt wamuil de intramunale sektor: Ten Horn en Giel kwamen tot eenzelfol the vinding, althans te n aanzien van de relatie tussen thet $A P Z$ en de $R$ Rarom (toen in die reigio de Stichting Geestellike Volksigezondheid, afdelingen SPD en SGD).

\section{DHSKUSSIE}

In 1978 konkludeerden Ten Horn en $\mathrm{Giel}$ het volgende: $O \mathrm{~m}$ kontinunteit van de geestelijke gezondheidszorg te watarborgen zal overleg bimnen een bepaald blok van voorzienini gen niet voldoende zijn. Samenwerking is ook nodig tussen instantites die organisatorisch miel duidelijk bij elkan horen" (Ten Horn en Giel, 1978, p. 24).

Enkele jaren llater blikkt er aluhanis in de regio Manstiricht. ussen diverse GGZorg-voorzieningen samengewerkt the wonden. Het groolste deel van hel multiple-service-use past dan ook in de beschreven regionale samenwerkingsverbanden of geinstitutionalisee rde overlegwormen. Daarnaiast is er in deze regio een krisiscincuill operationeel.

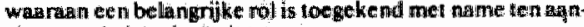
zien war de kontinutiteit wan tor:

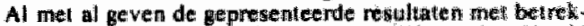
king tot het mult ple-siervice-use een gediffetentiecto bed

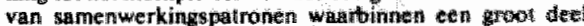
van dit gebruik heel funktioneel is. Dit gelde mo nas work

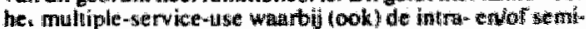
murale sektor betrokken is. Dit geldt in mindere mate voor

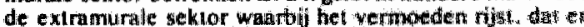
mede yan dysfunctioneel multiple-serviee-use spatak is zoals shopping around of koskenverhogend gebritk door inschrifwing bij twee woorzieninge n met min ol mes gethe mogelijkkieden.

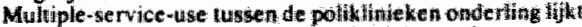
weinig op afspraken te berusten. Multiple-serice-use tussen poliklinicken en de vrijgevestigde zenuwartsen cater.

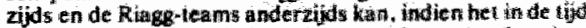
opeenyolgend platsinindu wel passer binnen de afspraten

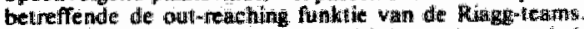
Een deel van dete vorm van multiple-service-usic with

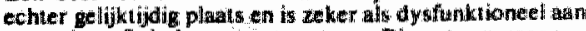
te merhen. Ook de overgang van een Riage-team mar cen polikliniek kan toch nauweligks als funktionet gexien worden.

Wij konstateendea dal er verhoudingigewits vee: funkto 


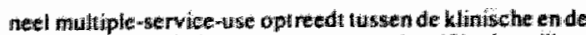
poliklinische afdelingen wan cen en dezelfide instelling.

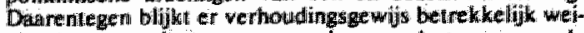
aig overtap te bestann tussen de centrale teamis van de Riags on de klinische funkties in de regjo. Alhow wel beide yormen wan gebruik funktioneel zijn, kin mien zich afwragen of de cenilnale neams wan de hiagg niel sterker in de ambulane (ourreaching) hailpvertening: ingeschakeld dienen te worden: Dit gebseurt nit al voonafgatande an een opname. Echier nadai ten opnome betindigd is, en er

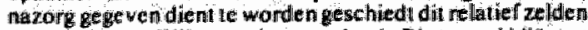
door de Riagg. Wil zagen immers dat de Rugg veel kifienten "wertiest' dath de intramisrale sektor (APZ en PAAZ) en

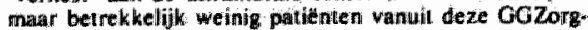
voorzieningen " cont vangl".

Opvallend of hel dall de samenwerkinguvormen platsvin. den rond enthele themp"s die om specialisatie wragen zoals de behandeling wan chronische patienten en de apwang bij akute krises. Het betreft dan veelal samenwerking tussen gespecialiseerde GOZorg-voorziteningen die tlkaar onder: ling sierk nowig thebiben om in gezamenijkthe id Gorzorg le leveren. Daarbij zijn vrijwel altijot intria of semimuirale voorzieningen betrokken en meestal enkele gespeciali" seerde exlrwmumale voorziteningen. Tussen de meer algemene funkties - myonteams waf de Rugs "de poliklinieken en de vrujgevestigde zenuwrartsen-zijin er in de regio geen: explicite te samen werkings verbanden of afspraken tot stand gehomen. Tegellikertijd blikt eit ook tussen deze voorzieningen multiple-service-use op te treden, warran een deel als negatief gezien moet warden.

Wij willen afshiken mel cen drietal oventegingen. Op de cersie plaals zou de GOZorg mocten overweger of de takverdeling itssen de extramumale voorzieningen op het getbied van onderzoek en behandeling een (beier) af hensiystem behoeft on het multiple-service-use te reduceren,

Op de rweede plaats ts het de vraag of bij de opnamew indicaties. gesteld door de 24-uurs Opvangpost en de poliw kitinielken voldoende aandacht is, besteed aan de ambiulante oull-reaching mogelijkheden. bifwoorbeeld door eerst te verwifizen naar een van de (centrale) teams wan de Riags.

Tenslotte ware her te overwegen om de nazorg te laten verrichten door die CGZorg-voorziening dit voór de klinische behandeling de extramurale GO20rg verzorgd heft. Dit zot grote voordelen hebben, omdat in die sithuatie de kontinumeil van; zorg dow minder hulpyerteners dan nu gerenliseerd kan worden.
Foor

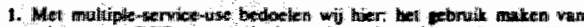

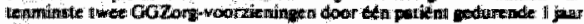
tad.

GUWMAMY

A grent deal of the persons who whe in care by the nersial bealth care

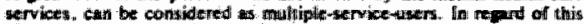
phenomenon twa questicins are impartant:

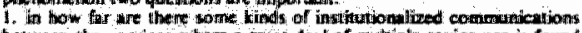

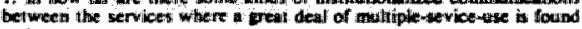
and

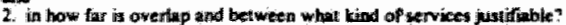

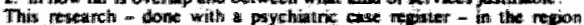

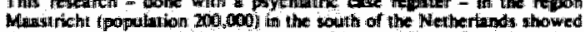
that mons of the overtag west coverned with some foma of collaboration.

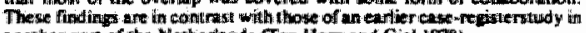
another pan of the Nethertands (Ten. Horn und Giel 1978).

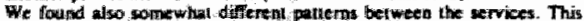

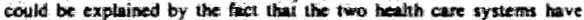
different sirvetlines. Expecially the nole of the service for mevasil health crises in the southern region was i very ianpoirtant ons.

\section{UTTEMTUUR}

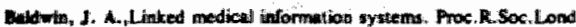
$184(1973) 403-420$

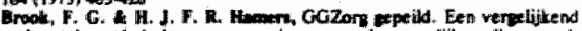

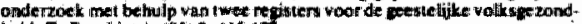
heid. T. Foychintre 6512 . 115127

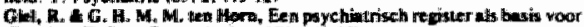

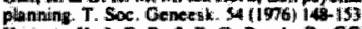

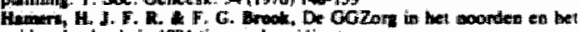

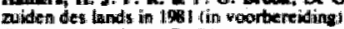

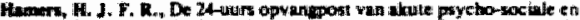

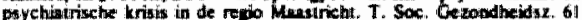
(19.9. 3) $802-805$

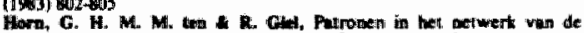

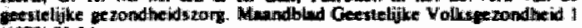
(1976) $23-344$

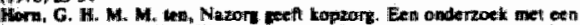

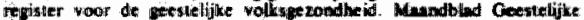

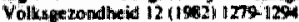

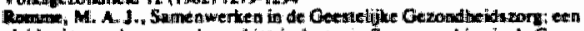

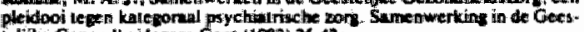
tallate Gerond heids som Genil (1992) 25-42

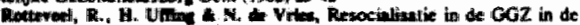

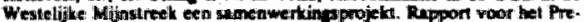

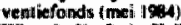

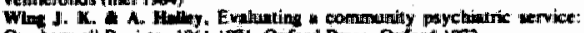

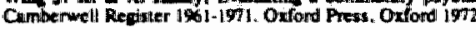

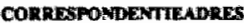

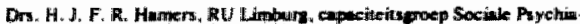

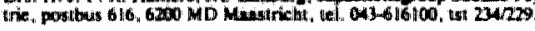




\section{2. 2. KORTDURENDE OPNAMEM IN PAAZ KN APZ: WIE MAAR UAAR?}

H.J.F.R.Hamers, G.A.M.Driessen en J.M.G.Lasker*

\section{Inleiding}

Zo'n tien jaar geleden is onder alle destijds actleve mAA-en (Psychiatrische Afdeling Algemeen Zlekenhuis) en APZ-en (Algemeen Psychiatrisch ziekenhuis) een onderzoek gehouden nax de taken van deze instellingen (Abraham \& Gunning, 1976). Daarbij werd geconstateerd, dat de eerste hulp en de opmame van patienten met ernstige desintegratietoestanden zowel in de PAAZ als in het APZ kon platsvinden. De PAAZ is daarnast geschikt voor patienten die behalve een intensleve psychosociale begeleiding ook een somatische behandeling behoeven, en het APZ voor patienten die aansluitend behoefte hebben aan klinische psychotherapie of langdurige verzorging.

Gedurende de laatste decennia blijkt het aantal eerste opnamen en in nog sterkere mate het antal heropnamen in het APZ sterk te zijn toegenomen. Dit geldt niet alleen voor de Nederlandse situatie (Brook, 1984; Haveman, 1980): ook elders werd dit fenomeen vastgesteld (Hafner \& Klug, 1982).

Door de stijging van het aantal kortdurende opnamen in het APZ en het bifna per definitie kortdurend zijn van de opnamen in de PAAZ, verzorgen beide voorzieningen eenzelfde functle.

Het overheids- en het reglonale beleid is gericht op het bevorderen van een betere samenwerking tussen voorzieningen in het gehele veld van de geestelijke gezondheldszorg (GGZ). Mede daartoe werden en worden er in Nederland Regionale Instituten voor de Geestelifke Gezondheidszorg (Rigg) opgericht, nadat al een groot deel van het ambulante veld onder én paraplu kwam (Riagg). Juist om deze Rigg-vorming optimaal te laten verlopen, is het van van groot belang om zowel de functies ls de daarult voortvloelende taken van de voorzieningen zo duldelifk mogelifk te beschrijven. Dit alies" om helder te krijgen in hoeverre er sprake is van afstemming of van overlap.

Terwifl er zowel in de PAAz alsook in het APZ kortdurende opmamen voorkomen, is het niet duidelijk of belde voorzleningen in deze te onderscheiden taken vervulien. Kortom: warin verschilt de kortopgenomen patient in de PAAZ met die in het APZ ?

* Allen verbonden an de vakgroep Sociale Paychiatrie van de Rijksuniversiteit Limburg. 
Wet behulp van een reglonal reglster voor de geestellfke volksgezondheid gestueerd in een gemeente in het noorden van het land (met en populatie wan ca, 45.000 inwoners) heeft men geprobeerd meer inzicht te krijgen in de specifieke taken van PAAZ en APZ (ten Horn, 1982). Het onderzoek heeft betrekking op de ontslagen van patienten van 15 tot 65 Jaer, in de periode 1974 tot en met 1978 . Om lets meer te veten te kamen over de acute opname-functie worden opnamen van mlnder dan twalf weken bekeken, een perlode die -hoewel ook gehanteerd door het $\operatorname{coz}^{1}$ - tamel1jk wilekeurig is gekozen. Uit het onderzoek b11jkt, dat PAAZ en APZ een vergel1jkbar andeel in de korte opnamen hebben, mar dat er in het soort patidnten verschillen $21 j \mathrm{n}$. Zo komen patidnten met psychosen of persoonlijkheidsstoornissen vaker terecht in het APZ en dle met neurosen of neurotische depressies vaker in de PAAZ. Ook konden APZ- en PAAZ-patienten verder getypeerd worden wat betreft de verdeling naar leeftifd en geslacht. Zo wordt van de groep patienten met en psychose bijna driekwart ult het APZ ontslagen, maar voor psychotische vrouwen beneden de 25 jaar en psychotische patiunten vanaf 55 jaar vervult de PAAZ weer een belangrijke rol. Het behulp van het item burgerlijke staat konden geen verdere nuanceringen porden a angebracht. Ondat de onderzoeksresultaten op etn reglo betrekking hebben, kan de vraag worden gesteld in hoeverre de bevindingen gegeneraliseerd kunnen vorden.

Zonder het problem van de generaliseerbarheld hier geheel op te lossen, presenteren wif onze bevindingen met betrekking tot de kortdurende opnamen in het APZ en de PAAZ. Onze bevindingen gelden voor de reglo zuldelijk Zuld-Limburg (populatie ca. 195.000 Inwonera ${ }^{2)}$ ).

Voor onze vraagstelling sluiten wij (in tegenstelling tot ten Horn) de leeftijdscategorle van 65 jaar en ouder in, ondat ons gebleken is, dat beide voorzieningen een belangrijke functie vervullen voor de bejaarde populatie en de vraag naar voren kont in hoeverre APZ en PAAZ ook voor deze categorie te onderschelden taken hebben.

De reglonale ituatie

Naast een APZ en en PAAZ is er in de regio een breed spectrum an GGZ-voorzieningen aamwezig (Brook Hamers, 1985; Hamers a., 1985; Hamers Brook, 1986). Uit eerdere prevalentietelingen - en vergelijkingen met de noordelijke reglo - bleek dat het aantal patienten in behandeling bij de GGZ in de regio zuidelifk Zuld-Limburg hoog is. Daarult kan vooralsnog slechts geconcludeerd worden, dat het anbod an GGZ groot is. Enkele verschilien tussen de prevalentleciffers voor twee reglo's dienen vermeld te worden, omdat -if verwachten dat de toen getrokken conclusies ook hier relevant zullen blijken. Uit de tellingen bleek dat er in beide regio's, zowel op 6en tijdstip lsook gedurende een geheel jaar, ongeveer evenveel 
bedden bezet waren. Echter, het bleek ook dat de opbouw van de Intramurale sector naar soort bed verschillend was. Zo werden in de reglo zuldelijk Zuid-Limburg meer patienten verpleegd op een verpleeghulsbed, terwijl in het noordelifke gebied meer pationten werden opgenomen in het $A P Z$ of de PAAZ. Bovendien bleek in zuldelijk zuld-Limburg een grote groep patienten kortdurend in het Crisiscentrum te worden opgenomen. Een dergelifke voorziening was in het andere registergebied niet aanwezig. Uit deze eerdere bevindingen blijkt dat or in het zuidelijk registergebied naar verhouding minder kortdurende opnamen in het APZ zulien plaatavinden dan in het noordelifk registergebled; voor de zuldelifke PAAz geldt dit in nog sterkere mate.

Afgezien van bovenstaande bemerkingen verwachten if nlet alleen de resultaten van ten Horn te kunnen bevestigen, maar verwachten wij ook dat de taken van het APZ en de PAAZ nu (1981-1984) meer complementair zijn in de regio zuidelijk Zuid-Limburg, dan toen (1974-1978) in het noordelijk registergebied. Immers Rigg-vorming en overleg tussen APZ en PAAZ zijn - in leder geval in zuldelijk zuid-Limburg - al geruime tijd realiteit.

\section{Methode}

Voor onze vraagstelling is een onderzoeksinstrument verelst, waarin de opnamen in het APZ en de PAAZ van bewoners woonachtig in $66 n$ regio worden vastgelegd, en warbij de informatie die per pationt en per (her) opname aanwezig is, volgens dezelfde regels verzameld wordt en dus vergelijkbaar is. Aan deze voorvaarden voldoet het register voor de GGz in de reglo zuldelifk Zuld-Limburg. In dit reglster - opgezet analoog an andere reglsters. Wing Halley, 1972; Giel \& ten Horn, 1976) - worden de gegevens van een patient nlet op naam, maar door middel van een warschijniljkheidscoppeling (Baldwin, 1973) bijeengebracht. Op deze wifze kunnen de gegevens per patiout aneengekoppeld en naar heropnamen geanalyseerd worden zonder dat de privacy van de patient in het geding komt (Hamers e..., 1986). overlgens heeft de discussie over privacy ertoe geleld dat gedurende de onderzoeksperiode met name in het APZ fluctuaties optraden in het aantal personen dat welgerde zijn gegevens in het register te laten opnemen. De variabelen dle bij de analyses worden gebrulkt $z 1 j n$ gecontroleerd op systematische vertekening als gevolg van deze velgeringen. Het biljkt, dat over een twetal jaren het antal fongere patienten ( 15 tot 25 jaar) ondervertegenwoordigd is. Wat betreft de verdeling naar diagnose, geslacht, burgerlijke stat en opnameduur werden geen verschillen in de tijd aangetroffen.

In het navolgende worden - analoog an het onderzoek van ten Horn ontslagen ten gevolge van overlijden en ontslagen resulterend in directe overplatising nar en andere intramurale voorziening bulten beschouwing gelaten. De informatie heeft betrekking op de Jaren 1981 tot en met 1984 . 
On de verschilien tussen APZ en PAAZ veer te geven zullen voor de analyses en de presentatie van de resultaten nast de gebruikelijke krulatabelien enkele minder vak gehanteerde methodieken gebrulkt worden, namelifk enkele zogenoemde snorredozen (Tukey, 1977) en loglinealre modelien (Haberman, 1979; Everitt, 1977). Bovendien is met behulp van laatstgemoende tochniek een deel ven de gepubliceerde gegevens van de noordelijke regleterstudie opnleuv geanalgaeerd en vergeleken met enkele van onze bevlndingen.

\section{Regultaten}

In tabel 1 wordt het percentage ontslagen patiunten uit PAAZ en APZ per opnameduur gepresenteerd. De opnameduur is gesplitst in kort (tot 85 dagen) en lang (85 dagen en langer). In de tabel zijn de gegevems opgenomen van twee leeftijdacategorieén: van 15 tot 65 jaar en van 65 Jar en ouder.

Tabe1 1 .

Het aandeel van PAAZ en APZ in de ontslagen na kort-en langdurende opnamen (in een reglo gedurende 1981-1984)

voor twee leeftijdscategoriedn.

\begin{tabular}{|c|c|c|c|c|c|c|}
\hline opnameduur & $\begin{array}{l}15-64 \\
\text { APZ }\end{array}$ & $\begin{array}{l}\text { Jaar } \\
\text { PAAZ }\end{array}$ & $\mathbf{N}=$ & APZ & $\begin{array}{l}65 \underbrace{}_{\text {JAAZ }} \\
\text { PAar }\end{array}$ & $\begin{array}{l}\text { en oude } \\
\mathrm{N}=\end{array}$ \\
\hline $\begin{array}{l}\text { tot } 85 \text { dagen } \\
85 \text { en meer }\end{array}$ & $\begin{array}{l}65.0 \\
88.8\end{array}$ & $\begin{array}{l}35.0 \\
11.2\end{array}$ & $\begin{array}{l}766 \\
251\end{array}$ & $\begin{array}{l}48.6 \\
71.4\end{array}$ & $\begin{array}{l}51.3 \\
28.6\end{array}$ & $\begin{array}{r}177 \\
77\end{array}$ \\
\hline totaal & 70.9 & 29.1 & 1017 & 55.5 & 44.5 & 254 \\
\hline
\end{tabular}

Tabel 1 late zien dat de kortdurende opnamen van patienten tot 65 jaar voor meer dan de helft $(65.0 \%)$ in het APZ plaatsvinden. De PAAZ neert lets meer dan de helft ( $51.3 \%)$ van de bejarde patienten voor zifn rekening.

De PAAZ Is voox de langer opgenomen bejaarde patient - in vergelijking met de populatie tot 65 jaar - belangrijk: van opnamen van 12 weken en langer wordt $11.2 \%$ van de patienten tot 65 jaar vanult de PAAZ ontolagen, bij de bejaarden is dit percentage $28.6 \%$. In het vervolg van dit artikel zullen wij ons beperken tot de kortdurende opnamen. 
In flguur 1 wordt de opnameduur van patienten - ontslagen binnen 84 dagen - veergegeven in een viertal snorredozen.

Figuur 1.

Opnameduur van ontsligen pationten na

kortdurend (tot 85 dagen) in APZ en PAAZ

opgenomen te $21 j n$, voor twee leeftijds-

categoriedn.

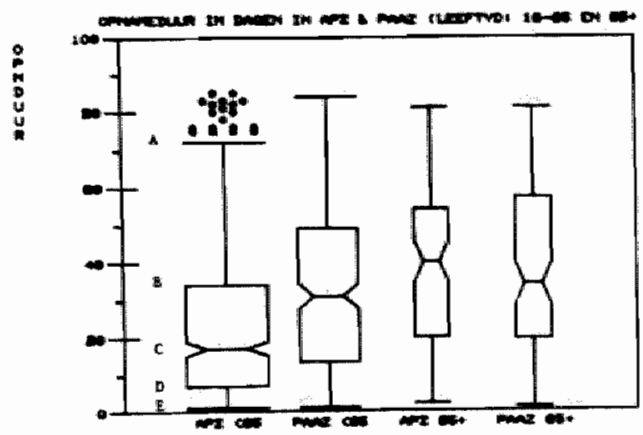

Een snorredoos deelt het antal warnemingen in vier gelifke delen; maar laat daarbij extreme warden die de figuur onrealistisch zouden beInvloeden, buiten beschouwing (in de eerste snorredoos a angegeven met de cirkeltjes boven $11 j \mathrm{n}$ A). Het eerste kwartlel vinden we bij de horizontale lifn $\mathrm{D}$. Op de $\mathrm{Y}-\mathrm{as}$ wordt de bljbehorende opnameduur afgelezen. Een kwart van de patienten van 15-65 Jaar wordt na een opnameperlode varierend van 1 tot 8 dagen ontsiagen ult het APZ.

Het tweede kwartiel (de mediaan) is met de horizontale $11 \mathrm{fj}$ C gemarkeerd. Nog eens $25 \%$ wordt ontalagen na een opnameduur varierend van 9 dagen (D) tot 18 dagen (C): de helft van de (kortdurend) opgenomen patienten wordt dus binnen 18 dagen ult het APZ ontslagen. De inkepingen bij C (taile) geven het $95 \%$ betrouwbarheidsinterval van de mediaan veer. Overlappen deze intervalien van twee snorredozen - lkaar niet (b.v. de eerate twee snorredozen ult figuur 1), dan verschilien de medianen significant van elkaar. De breedte van de snorredoos wordt bepald door de wortel ult het antal warnemingen (Does, e.a., 1983). Zo blijkt uit de eerate twee anorredozen dat uit het APZ meer mensen - in de leeftijdscategorio 15 tot 65 jaar worden ontsigen dan ult de PAAZ.

De opnamedur van pationten tot 65 Jaar is in de PAAZ langer dan in het APZ: de helft van de patienten van de PAAZ is na 30 dagen ontslagen, bif het APZ is dit na 18 dagen het geval. Dit verschil is significant. Voor de $65+$ groep treffen we de omgekeerde situatio an: de opnamedur in het APZ is langer. De helft van de APZ patienten is na 41 dagen ontslagen; van de PAAZ patiunten na 38 dagen. Dit verschil is echter niet significant. 
Worden de ouderen en de fongeren binnen een lnstelling met elkaar vergeleken, dan blifkt dat de 65 t groep in het APZ ignificant langer verblifft dan de groep tot 65 jaar. De oudere patient in de PAAZ verbliff gemiddeld ook lets langer, maar dit verschll is niet significant.

In het navolgende wilien if de patientenpopulaties in belde voorzleningen analyseren nar gestelde diagnose, leeftijd en geslacht. In tabel 2 is een overzicht gegeven van patienten die in de perlode 1981-1984 binnen 85 dagen uit APZ en RAAZ ontslagen worden, utgesplitst naar leeftijd (15-64 jaar en 65 jaar en ouder), le en heropname, voorzlening en diagnose.

Tabel 2. Diagnostiek b1j APZ en PAAZ-ontslagen binnen 85 dagen voor twe leeftijdacategoriebn: voor alle, de eerste en de heropnamen.

$$
\text { 15-64 Jaar }
$$

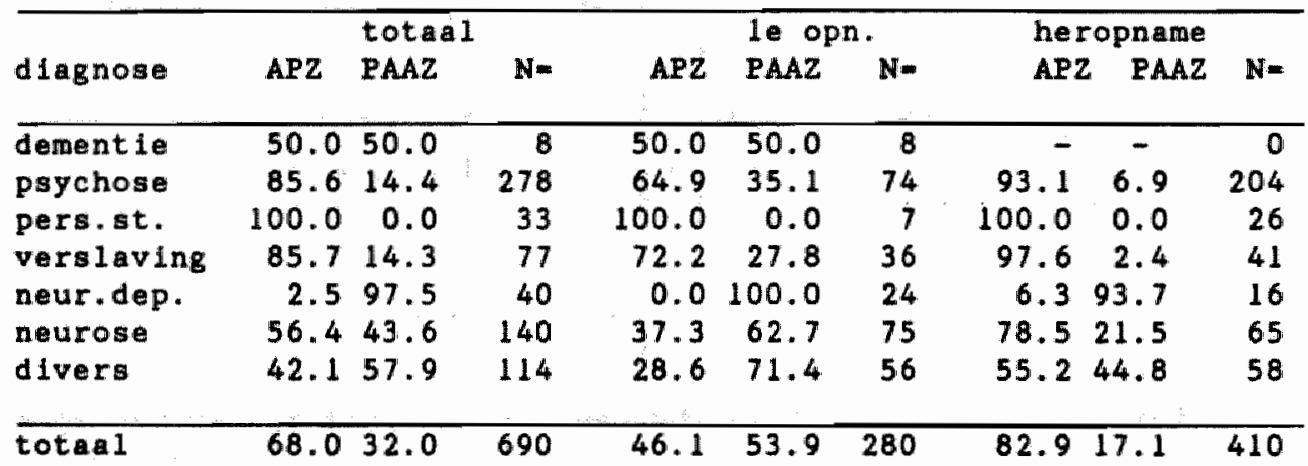

65 Jaar en ouder

\begin{tabular}{|c|c|c|c|c|c|c|c|c|c|}
\hline \multirow[b]{2}{*}{ diagnose } & \multicolumn{3}{|c|}{ totaal } & \multicolumn{3}{|c|}{ le opn. } & \multicolumn{3}{|c|}{ heropname } \\
\hline & APZ & PAAZ & $\mathbf{N}=$ & $\mathrm{APZ}$ & PAAZ & $N=$ & APZ & PAAZ & $N=$ \\
\hline dement 10 & 76.9 & 23.1 & 39 & 68.2 & 31.8 & 22 & 88.2 & 11.8 & 17 \\
\hline peychose & 69.2 & 30.8 & 39 & 58.2 & 41.2 & 17 & 77.3 & 22.7 & 22 \\
\hline pers.st. & 100.0 & 0.0 & 3 & - & - & 0 & 100.0 & 0.0 & 3 \\
\hline verslaving & 25.0 & 75.0 & 4 & 25.0 & 75.0 & 4 & - & - & 0 \\
\hline neur.dep. & 11.1 & 88.9 & 27 & 10.0 & 90.0 & 20 & 14.3 & 85.7 & 7 \\
\hline neurose & 33.3 & 66.7 & 27 & 13.3 & 86.7 & 15 & 58.3 & 41.7 & 12 \\
\hline divers & 33.3 & 66.7 & 18 & 11.1 & 88.9 & 9 & 55.6 & 44.4 & 9 \\
\hline totaa 1 & 50.3 & 49.7 & 157 & 35.6 & 64.4 & 87 & 68.6 & 31.4 & 70 \\
\hline
\end{tabular}

onbekend: 104 
Voor de leeftijdscategorle 15-64 Jaer zlen wi dat het APZ de meste psychosen $(85.67)$, alle persoonlijkheldsstoornissen an de meeste verslavingen ( 85.77 ) voor zijn rekening neemt. De PAA daarentegen zlet vrijwel alle neurotische depressies $(97.57)$ en wat betreft de nourosen heeft de PAAZ een lets kleiner andee1 $(43.67)$ dam het APZ.

Voor de leeftijdscategorie van 65 jaar en ouder alem wij ten dele eenzelfde verdeling. Zo heeft ook nu het AFZ het grootste andeel in de psychosen $(69.2 \%)$. Van de neurotische depressies worden de meeste binnen de PAAZ behandeld $(88.97)$; datzelfde geldt voor de categorie neurosen $(66.77)$. Het APZ neemt ongeveer driekwart van de dementiedn (76.98) voor zijn rekening.

Van de hier gepresenteerde informatie betreffende kortdurende opnamen heeft een deel betrekking op heropnamen. De diagnostiek bezien voor de eerste en de heropnamen, levert geen wezenlijk ander beeld. BIJ de heropnamen (voor fongere en oudere patiunten) zijn de eerdere constateringen nog wat uitgesprokener (psychosen en verslavingen), terwijl de categorie neurosen richting APZ verschulft.

Ten lotte is uit deze tabel af te lezen dat de PAAz een belangrijke voorziening voor eerste opnamen is voor de 15-64 Jarlgen (53.9\%), mar in nog sterkere mate voor de bejaarde populatie (64.4I). Wat betreft de heropnamen: deze vinden vooral in het APZ plaats (82.9\% voor de 15-64 jarigen en 68.6\% voor de 65 jarigen en ouder).

Bif 132 patienten (ongeveer 16\%) werd de diagnose in de categorie 'divers' ondergebracht (het betreft 114 15-64 Jarigen en 18 65-plussers). Een groot deel van deze categorie 'divers' omvat tentamen-sulcide ( $33 \%)$, terwijl verder een aantal patienten gedlagnostiseerd blijken onder de term anpassingsreacties (20\%). Verder zien wij enkele keren misbrulk drugs, gedragsstoornissen e.d.. Sulcideg treffen wj voornamelijk in de PAAZ an; de andere categorieun in belde voorzieningen.

In het navolgende zullen wj de patilenten van 15-64 jaar wat betreft de verdeling over de voorzleningen per leeftijdscategorle beschouwen, ultgesplitst naar diagnose en geslacht. Uit tabel 3 blifkt dat per dlagnostische categorie de verdeling over de voorzlemingen tamelijk constant is voor de drie onderscheiden leeftijdscategorletn.

Tabe1 3. Diagnostiek bij patienten (tot 65 jaar) ontslagen binnen 85 dagen uit APZ en PAAZ uitgesplitst nar enkele leeftijdacategoriedn.

\begin{tabular}{|c|c|c|c|c|c|c|c|c|c|c|}
\hline & $15-2$ & $4 \mathrm{jr}$ & & $25-4$ & $4 \mathrm{Jr}$ & & $45-$ & $4 \int r$ & & \\
\hline dagnose & APZ & PAAZ & $\mathbf{N}=$ & $\mathrm{APZ}$ & PAA2 & $N=$ & & & $\mathrm{AZ}$ & $\mathrm{N}=$ \\
\hline dementie & - & - & 0 & 50.0 & 50.0 & 2 & 50.0 & 50.0 & 6 & \\
\hline psychose & 89.7 & 10.3 & 29 & 89.4 & 10.6 & 141 & 79.6 & 20.4 & 108 & \\
\hline pers.st. & 100.0 & 0.0 & 6 & 100.0 & 0.0 & 14 & 100.10 & 0.0 & 13 & \\
\hline verslaving & 100.0 & 0.0 & 9 & 81.3 & 18.7 & 32 & 86.1 & 13.9 & 36 & \\
\hline meur.dep. & 0.0 & 100.0 & 2 & 0.0 & 100.0 & 13 & 4.0 & 96.0 & 25 & \\
\hline neurose & 70.0 & 30.0 & 10 & 58.6 & 41.4 & 70 & 51.7 & 48.3 & 60 & \\
\hline divers & 36.4 & 63.6 & 11 & 50.9 & 49.1 & 55 & 33.3 & 66.7 & 48 & \\
\hline totaa 1 & 77.6 & 22.4 & 67 & 72.2 & 27.8 & 327 & 61.1 & 38.9 & 296 & \\
\hline
\end{tabular}


De neurosen, die in de leeftijdsgroep 25-64 jaar gelijkelijk over belde voorzieningen verdeeld $\mathrm{zlj}$, worden in de leeftijdscategorie 15-24 jaar meer in het APZ opgenomen. De categorle 'divers' wordt voornamelifk in de PAAZ angetroffen blj de jongeren en de ouderen (reapectlevel1jk 15-24 jaar 63.67 on 45-64 jaar 66.77), terwij1 de categorfe 'divera' bij de middengroep (25-44 jaar) gelijkelifk is verdeeld over PAAZ en APZ (resp. 50.9 en 49.1z).

De verdeling naar leeftijd en geslacht wordt in tabel 4 weergegever.

Tabe1 4. Verdeling naar geslacht van patienten (tot 65 jaar) ontslagen binnen 85 dagen uit APZ en PAA uitgegplitst naar enkele leetifdscategorledn.

\begin{tabular}{|c|c|c|c|c|c|c|c|c|c|}
\hline geslacht & $\begin{array}{l}15-2 \\
\text { APZ }\end{array}$ & $\begin{array}{l}j x \\
\text { PAAZ }\end{array}$ & $\mathrm{N}=$ & $\begin{array}{l}25-4 \\
\text { APZ } \\
\end{array}$ & $\begin{array}{l}j \mathrm{r} \\
\text { PAAZ }\end{array}$ & $\mathbf{N}=$ & $\begin{array}{l}45-6 \\
\text { APZ }\end{array}$ & $\begin{array}{l}\int r \\
\text { PAAZ }\end{array}$ & $\mathrm{N}=$ \\
\hline $\begin{array}{l}\text { man } \\
\text { vrouw }\end{array}$ & $\begin{array}{l}77.8 \\
66.7\end{array}$ & $\begin{array}{l}22.2 \\
33.3\end{array}$ & $\begin{array}{l}45 \\
27\end{array}$ & $\begin{array}{l}75.3 \\
62.8\end{array}$ & $\begin{array}{l}24.7 \\
37.2\end{array}$ & $\begin{array}{l}198 \\
164\end{array}$ & $\begin{array}{l}63.3 \\
54.1\end{array}$ & $\begin{array}{l}36.7 \\
45.9\end{array}$ & $\begin{array}{l}147 \\
185\end{array}$ \\
\hline totaa 1 & 73.6 & 26.4 & 72 & 71.6 & 28.4 & 362 & 58.2 & 41.8 & 332 \\
\hline
\end{tabular}

In de leeft 1 jdscategorie tot 45 jaar wordt ongeveer driekwart van de mannen in het APZ opgenomen. Worden de mannelijke patienten ouder, dan neemt de PAAZ lets meer mensen op. Eenzelfde beeld treffen we ook bij de vrouwelifke patidnt aan. Tot 45 jaar verblifft circa tweederde in het APZ. Van de $45+$ groep gat bijna de helft van de vrouwen naar de PAAZ. Voor leder van de drie leeftijdscategorieun geldt dat de PAAZ relatief meer vrouwen opneemt.

De resultaten ander vergeleken

Hier worden onze resultaten met die van ten Horn nader vergeleken, warbij wij ons beperken tot de ontslagen van patienten in de leeflddscategorie van 15 tot $65 \mathrm{jaar}$.

Dartoe $z i j n$ de resultaten op een andere wijze geanalyseerd; namelijk door iniddel van een loglinealre analyse (Norusis, 1985). Een dergelijke methode beoogt 0.0 . relaties vast te stellen tussen een gedichotomiseerde afhankelijke variabele en een set onafhankelijke varlabelen van en la $\mathrm{ag}$ meetniveau.

Allereerst hebben wj gezocht nar een loglineair model dat goed paste op de erder gepubliceerde data met betrekking tot de ahankelifke varlabele (soort ziekenhuis, APZ of PAAZ) en een tweetal onafhankelijke variabelien, te weten: de gestelde diagnose en een eerste of en heropname (zle ook tabel 4 in ten Horn, 1982). 
Het uitelndelijke model -en de belangrijkste resultaten- zijm in tabel 5 gepresenteerd. Dit model heeft een perfecte 'goodness of $f(t)$ ondat het een verzadigd model betreft warin dus alle mogelljke interacties zijn opgenomen. (Voor dit model is gekozen, omdat een eenvoudiger - zonder de drleweg-interactle - significant van de geobserveerde warden afweek en dus niet als een weersplegeling daarvan opgevat kon worden.)

Tabel 5. De resultaten van een heranalyse van ten Horn's data (ten Horn, 1982, p.601): een loglineair model warin ziekenhuls als afhankelijke en diagnose (excl. dementle, divers en onbekend) en (her)opname als onafhankelijke variabelen zijn opgenomen (voor de leeftifdscategorie 15 tot $65 \mathrm{jaar}$ ).

Mode 1 Geschatte coufficient

ziekenhuis

1. APZ

$-0.074$

ziekenhuis tegen (her)opname

2. 1e. opname

$-0.145$

ziekenhuis tegen diagnose

$\begin{array}{ll}\text { 3. psychose } & 0.493 \\ \text { 4. pers.st. } & 0.254 \\ \text { 5. verglaving } & 0.103 \\ \text { 6. neur.dep. } & 0.349\end{array}$

zlekenhuis tegen (her)opname tegen dianose

\begin{tabular}{llr}
\hline 7. & psychose & 0.125 \\
8. persist. & -0.098 \\
9. & verslaving & 0.303 \\
10. neur.dep. & -0.134
\end{tabular}

Associatiematen: concentration $=0.189 /$ entropy $=0.146$

Goodness of $f$ it statistics: likelihood ratio chi square $=0 \mathrm{df}=0 \mathrm{p}=1.00$ pearson chi square $\quad$ o df $=0 \mathrm{p}-1.00$

De analyse heeft betrekking op 443 gevallen: 48 gevallen zijn niet in de analyse opgenomen.

De coufflcient voor de heropname is +0.145 en voor neurose -0.501 , omdat de coeffienten behorend bij een variabele in dit model te zamen nul zijn. De coßfficienten leren ons, dat de kans op een eerste opname in het APZ kleiner is dan in de PAAZ en dat en psychotische patient een grotere kans heeft in het APZ te belanden.

Wit de associatiematen is af te lezen hoe groot de reduktie is ten anzien van de fout-classiflcaties op de varlabele soort zlekenhuls; de reductie m.b.v. dit model en deze variabelen is ongeveer 17\%. Een goortgelifk model is voor onze elgen data bepald. Daarin is echter de interactie tussen (her)opname en diagnose ten opzichte van het 
soort ziekenhul reggelaten, ondat dit geen substanticle bifdrage opleverde. (DIt ondat gekozen dient te vorden voor het meest envoudige model, tenminste indien de 'goodness of fit statistics" het toelaten.)

De resultaten vam beide loglinealre modellen lopen in grote lijnen parallel zif het dat er en belangrijk vergehil ontatat door het aterkere contrast tussen de voorzleningen in het zuidelijk registergebled: een verschil tot ulting komend in hogere associatlematen. (De foutreductle is voor onze data ongeveer $30 \%$ met behulp van de varlabelen (her)opname en diagnoge).

Vervolgens hebben wf enkele modellen, warin ook andere variabelen opgenomen werden met behulp van onze data getest. De modellen warin leeftifd en geslacht opgenomen werden voldeden niet; deze variabelen leverden nauwelijkg een bijdrage ter verklaring van de scores op de onafhankelifke variabele. Hier presenteren wij een model, waarin (her)opname, dlagnose en burgerlijke stat (teruggebracht tot twee categorlegn) als onafhankelijke varlabelen zijn opgenomen.

Tabe1 6. De resultaten van een analyse over de kortdurende APZ en PAAZ opnamen in zuldelijk Zuid-Limburg: een loglineair mode1, waar in ziekenhuis als afhankelijke en diagnose (excl. dementie, persoonlijkheidsstoornis, divers en onbekend), (herlopname en burgerlijke stat (alleen of gehuwd) als onafhankelijke variabelen zijn opgenomen (voor de leeftijdscategorie 15 tot 65 Jaar).

Mode 1

Geschatte coèfficiènten

ziekenhuts

1. $\quad$ APZ

zlekenhuis tegen (her)opname

2. le. opname -0.483

zekenhuls tegen dignose

$\begin{array}{ll}\text { 3. paychose } & 0.717\end{array}$

4. verslaving 0.858

5. neur. dep. -1.759

zikenhu is tegen burgerlijke stat
6. a11an
0.245

Assoclatiematen: concentration=0.404 I entropy= 0.349

Goodness of fit statistics:11kellhood ratio chi square= 2.21 df $=10$

$p=0.994$

person chi square

$=2.87 \mathrm{df}=10$

$p=0.953$

De analyse heeft betrekking op 521 gevallen: 243 zijn nlet in de analyse megenomen (hlervan blijken 93 onbekend). 
In dit model (tabel 6) zijn de diagnostische categoriean dementie, persoonlijkheidsstoornls (omdat deze alleen in het APz voorkomen) en divers uftgesloten; het item burgerlijke stat is gehercodeerd in gehuwd en alleenstaand (ongehuwd, gescheiden of weduwstaat). Vanuit dit model kan per cel worden bepald, hoe groot de kans 1s, dat een bepaaldę) combinatie (als voorspelde warde) voorkomt. Bljvoorbeeld: de kans dat een psychotische alleenstaande patilnt bif zijn eerste opname in het APZ terecht komt is 0.65 (en 0.35 voor de PAAZ). In het noorden zijn deze waarden (nlet gedifferentiferd naar burgerlijke staat) 0.55 (APZ) en 0.45 (PAAZ).

Bij heropnamen van psychotische gehuwden is in het zulden de kans 0.86 om in het APZ terecht te komen; voor alleenstaanden ls die kans bif een heropname 0.95 . In het noorden is de kans 0.75 voor psychotici (ongeacht de burgerlifke staat) om bif een heropname in het APZ terecht te komen. Gehuwde patienten met een neurotische depressie hebben in het zuiden een zeer grote kans bij een eerste opname in de PAAZ terecht te komen (praktisch 1.0); voor de alleenstaande is die kans 0.98 (in het noorden is die kans 0.75 ).

Neurotici hebben in het zuiden een grotere kans dan in het noorden om bij een heropname in het APZ terecht te komen (namelijk 0.85 -alleenstaanden- en 0.60 -gehuwden- in het zuiden tegenover 0.29 in het noorden).

In het algemeen zijn in het zuiden de waarden wat betreft de "kansen" extremer dan in het noorden. Ook geven de analyses aan dat de kans voor de verschillende categorieern om of in het APZ of in de PAAZ te worden opgenomen in dezelfde richting wijzen. M.a.w. neurotisch depressieve pationten hebben -bij eerste en vervolgopnamen- in beide regio"s de meeste kans in de PAAZ terecht te komen. Datzelfde geldt voor neurotische patienten bif een eerste opname; voor de heropmamen in het zuiden gaat dit niet meer en in het noorden wel op.

Ten slotte is het van belang erop te wijzen dat wellawar de speciflciteit voor beide voorzieningen in beide regio's op een vergelijkbare wijze anwezig is, mar dat deze in het zuiden groter blijkt.

\section{Discussie}

Uit onze resultaten blijkt, dat bij patienten jonger dan 65 jaar de opnameduur van kortdurende opnamen (tot 85 dagen) in de PAAZ langer is dan die in het APZ. Een vergelijking met de noordelifke regio leert, dat de opnameduur in de zuidelijke PAAZ nlet langer is dan in de noordelijke PAAZ. Daarentegen ontslaat het zuidelijk APZ zijn patienten sneller dan het noordelifk APZ.

Bezien we de diagnostische verdeling in beide regio's dan blifkt in het zuiden de categorle psychose vaker in thet APZ voor te komen. Neurotische depressies komen in het zuiden bijna geheel voor rekening

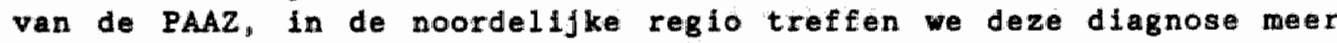
(dan in de zuidelijke regio) aan binnen het APZ. 
Er blijken in het zulden naar verhouding meer heropnamen in het APZ plats te viaden, terrijl de opnamedur in deze zuidelifke voorziening kort te noemen 1s. On daaraan een negatieve konklusie te verbinden (Brook, 1984), liJkt ons mede gezien andere onderzoeksresultaten (Hattes, 1982) voorbaris.

Wat betreft de heropnamen zien if In belde regio's dezelfde accenten met die restrictle, dat in het zuiden de heropnamen van neurotische patienten voornameIijk in het APZ en in het noorden in de PAAZ platsvinden. De dignose neurotische depressie treffen we in het zuiden bij een eerste opname witsluitend bij de PAA aan "bij heropnamen komt deze categorfe in geringe mate ook voor bif het $A P Z$. Gelden de door ten Horn getrokken conclusies ook voor zuldelijk Zuld-Limburg ondanks enkele gesignaleerde versehillen?

De diagnostische verdelingen lelden niet tot afwijkende profielen voor overeenkomstige voorzieningen in beide regio's. In beide regio's zifn dezelfde accenten gesignaleerd. Uiteraard is het mogelijk, dat er diagnostische voorkeuren - per reglo of per voorziening - bestaan die de resultaten belnvioed kunnen hebben. Echter de geconstateerde verschilien tussen belde voorzieningen en overeenkomsten tussen beide regio's zijn groot.

Hoewel het a antal kortdurende opnamen in APZ en PAAZ in verhouding tot die in het noordelijk registergebied klein is en met name de PAAZ een klein andeel in het antal opnamen heeft, konden wij de bevindingen van ten Horn bevestigen. Zelfs blijkt onze verwachting, dat APZ en PAAZ in het zuiden in sterkere mate complementafr zouden zijn dan in de door ten Horn onderzochte reglo, uit te komen. Rig-vorming $11 \mathrm{Jkt}$ ook positieve aspecten te hebben, zeker daar war dit daadwerkelijk leidt tot afsteming van de GGz-voorzieningen op elkaar. In dit licht bezien zou het interessant zijn om na te gaan in hoeverre de altuatie in de noordelifke regio momenteel is veranderd. In ten Horn"s en ons onderzoek is gebruik gemaakt van de grens van twaalf weken om kortdurende opnamen vast te atellen. Deze grens is als reods gezegd - tamelfjk willekeurig te noemen. Wij pleiten ervoor de te onderzoeken opnamen op stat 1 stische gronden te selecteren. Dit zou kunnen gebeuren door de opnameduur van de FAAZ als criteriunt te stellen. We hebben en mat voor de beneden- en bovengrens van de opnameduur als we het $95 \mathrm{z}$ betrouwbarheidsniveau uit de verdeling van de totale opnameduur In de PAAZ nemen. Bovendien zijn de FAAZ en het APZ nlet de enlge voorzieningen war kortdurende opnamen plaatsulinden; om functies en taken binnen de totale GGz vast te stellen zullen ook andere voorzleningen (zoals b. $v$, het Crisiscentrum in het zulden war tijdens de onderzoeksperiode meer dan 1000 kortdurende opmamen plativonden) bij vervolgonderzoek betrokken moeten worden.

Vervolgens doet de vraag zich voor hoe de opnamen en de daarbif betrokken patidnten met elkaar vergeleken kunnen worden. In eerste Instantle kunnen verschillende kruistabellen gemaakt worden. Het nadeel hierbij is dat, gezien de vele variabelen, al snel door de 
bomen het bos niet weer wordt gezien. Een multi-varlate technlek, zoals de boven gehanteerde loglinalre modellen, blljkt daartoe een oplosing an te reiken.

noot 1: nu C.O.T.G. ofwel Central Orgaan Tarleven Gezondheldszorg. noot 2: in eerdere publikaties is een inwoneraantal van ongeveer 200.000 gemeld. T.g.v. gemeentelifke herlndelingen omvat de huidige registerregio lets minder inwoners.

noot 3: de kans wordt als valgt berekend: de van toepassing zijnde coëfficienten worden opgeteld en met twe vermenlgvuldigd; de ant $110 \mathrm{~g}$ van dit getal geeft de kans aan. Dus de kans dat een psychotische alleenstarnde patient bij een eerste opname in de PAAZ terecht komt, is als volgt berekend:

$2 *(-0.040+0.483-0.717-0.245)=-1.038$

de antilog van dit getal is 0.35 .

\section{Literatuur}

Abraham, R.E. W.B. Gunning: De reglonale psychlatrische kliniek en de psychiatrische afdeling van een algemeen ziekenhuis. Medisch Contact, $1976 ; 17: 513-520$.

Baldwin, J.A.: Linked record medical informationsystems. Proceedings of the Royal Society of London, series B, 1973; 184: 403-420.

Brook, 0.H.: Heropnemingen in de Algemene Psychiatrische Zlekenhuizen in de periade 1970 tot en met 1980. Tijdschrift voor Psychiatrie, $1984 ; 26: 500-525$.

Brook, F.G. H.J.F.R. Hamera: GGZ gepeild. Een vergelifkend onderzoek met behulp van twee registers voor de geestelifke volksgezondheid. Tijdschrift voor Psychiatrie, 1985; 27 ; 115-127.

Does, R., A. Koning, L. Strijbosch \& L. Volovics: Syllabus. Data Analyse: exploratie en evaluatie. Capaciteitsgroep Medische Informatica en Statistiek, september 1983.

Bveritt, B.S.: The analysis of contingency tables. London, 1977.

Glel, R. G.H.M.M. ten Horn: Een psychiatrisch register als basis voor planning. Tijdschrift voor Sociale Geneeskunde, 1976:54: $148-153$

Haberman, S.J.: Analysis of qualitative data. Vol. 2. Academic Eress, New Hork, 1979.

Hafner, H. * J. Klug: The impact of an expanding commulty mental health service on patterns of bed usage: evaluation of four-year period af implementation. Psychological Medicine, 1982; 12 : $177-190$.

Hamers, H.J.F.R., M.A.J. Rome \& G.A.M. Driessen: Het (on)bedoelde gebrulk van meer geestelifke gezondheldszorg voorzieningen. Tijdsehrift voor Sociale Gezondheidszorg, 1985; 13:506-511.

Hamers, H.J.F.R. F.G. Brook: De GGZ in het noorden en zulden des 
lands In 1981. Tijdachrift voor Paychiatrie, 1986; 28: 254-266.

Hamers, H.J.F.R., H.A.J. Rome H.W. deVries: Resistance, Rrivacy and Technology: comments on the negoclations of the case register In Maastricht. In: G.H.M.M. ten Horn, R. Giel, W.H. Gulbinat J.H. Henderson (eds), Paychiatric Case Registers in Public Health, 1960-1985. Elaevier Science Publishers BV, 1986.

Haveman, H.J.: De frequent opgenomen psychiatrische patidnt-draait de draaldeur selectief (II). Tijdschrift voor Esychiatrie, 1980; 22 : $267-277$.

Horn, G.M.H.H. ten: Kortdurende opnamen: elgen taken voor de PAAZ en het paychiatrisch zlekenhuls. Het zlekenhuls, 1982; 11, vol.12: $601-603$.

Mattes, J.A.: The optimal Length of Hospitalization for Psychiatric Patients: A reviev of the Literature. Hospital and Community Psychiatry, $1982 ; 33$ (10): 824-828.

Morug1s, M.J.: SPSS-X Advanced statistics guide. New York, 1985

Tukey, J.W.: Exploratory Data Analyses. Reading, Massachusetts, 1977.

WIng, J.K. A.M. Hailey: Evaluating a comunity psychiatric service:

Camberwe11 reg1ster 1961-1971. University Oxford Press, 1972. 


\subsection{Samenvatting}

In dit hoofdstuk is gekeken naar het functioneren wan de cGZ als regionale organisatie: uiteraard dienden op dit punt beperkingen a angebracht te worden. Een van de belangrijkste constateringen hier is, dat het mogelijk blijkt de GGz op zijn functioneren te beoordelen. En hoewel hierover (ook onderzoekstechnlsch) veel meer te zeggen is (zie b.v. Beenackers, 1986), is deze constatering op zich al positief en ultnodigend voor verder onderzoek.

Hier werden een tweetal concrete vraagstellingen an de orde gesteld: de eerste vraagstelling is erop gerleht an te geven hoe de (regionale) GGZ beleidsmatig ongat met patienten dle of in de tifd opeenvolgend of op én moment gebruik van meer GGz-voorzieningen maken. De hypothese-zoals die in hoofdstuk 5 geformuleerd is en hier ter toetsing voorligt- luldt als volgt: "de overlap tussen GGz-voorzieningen is in vergelijking met het verleden in sterke mate 'gedekt' door samenwerkingsverbanden tussen die GGZ-instelingen. De achtergrond van deze hypothese 1 s gelegen in de veronderstelling dat een deel van het $z \cdot g$. dubbelgebruik functioneel te noemen zal zijn, maar dat er dan aok sprake dient te $z i j n$ van samenwerkingsverbanden, overlegstructuren, e.d. wardoor dit potentlel functioneel gebruik van de zorg ook daadwerkelijk functionel wordt, en de geboden (GG)zorg verbetert.

In het verleden bleek er -althans in een andere regio (ten Horn \& Giel, 1978)- onvoldoende sprake van samenwerking tussen instanties die organisatorisch niet duidelifk bif elkar behoorden, terwijl patienten zich van deze grenzen mar weinig bleken (en nog blifken) aan te trekken. Paragraaf 8.2.1. bevat een beschrijuing van de regionale GGZ die ik hier onderzocht, waarbif ook de anwezige samenwerkingsverbanden en overlegstructuren gelinventariseerd werden. Daarnaast werd bekeken hoe het dubbelgebruik aanwezlg was en in welke mate dit correspondeerde met de beschreven samenwerkingsverbanden en overlegstructuren.

Te concluderen is, dat 1) een groot deel van het dubbelgebrulk correspondeert met de angebrachte dwarsverbanden in de GGZ en dit dubbelgebruik functioneel te noemen is, 2) het dubbelgebrulk in de regio zuidelijk zuid-Limburg in vergelifking met det in de noordelijke registerregio qua omvang zeker niet gering is en 3 ) de verschijningsvorm van het dubbelgebruik in deze reglo ten dele anders is dan in de noordelifke regio ten gevolge van een andere GGZ-structuur (b.v. voor 1978 het ontbreken van een RIAGG in het noorden en de anwezigheid van een 24-uurs berelkbarheidsdienst sinds 1980 in het zuiden).

De hypothese als gesteld in hoofdstuk 5 dient geaccepteerd te worden: wel behoort daarbij de opmerking dat de toeting plaats vindt door een vergelijking in de tijd en in de rulmte, 1 mers de GGZ in de regio zuidelijk zuid-Limburg nu (1981) tegenover die in een middelgrote gemeente in het noorden van Nederland toen (1974). 
De volgende hypothese vordt langs dezelfde weg getoetst. On deze hypothese in vergelijking met het verleden is er een duldelijker takkafbakening at betreft kortdurende opnamen in het APZ en de PAAZ" te toetsen werden vooreerst de kortdurende opnamen in die GGZ-voorzieningen in het zuiden (1981-1984) besproken. De bevindingen werden vervolgens vergeleken met die van ten Horn (19B2) betrekking hebbend op kortdurende opnamen in APZ en PAAZ vanult de noordelijke registerregio gedurende de perlode 1974-1978.

Kort gesteld kan geconcludeerd worden, dat de bevindingen van ten Horn in het zulden gerepliceerd konden worden; echter ook bleek dat de functies van APZ en PAAZ in het zulden beter t.o.v. elkar te onderscheiden $z 1 j n$ met behulp van de in die GGZ-voorzieningen platsvindende kortdurende opnamen.

Gesteld kan worden, dat de vermoede onduidelifkheid (inzake de functieafbakening van APZ en PAAZ t.a.v. kortdurende opnamen) in de zeventig Jaren al niet zo groot was, maar ook dat de afbakening in het zulden -wellicht t.g.v. RIGG-vorming en een beleidsmatige onderlinge afsteming tussen de GGZ-voorzieningen- nu groter is dan toen in het noorden.

Het is in die zin -door het kunnen accepteren van beide hypothesen betreffende de $\mathrm{GGZ}$ als organisatie- dat de rationaliteit waraan de GGZ Immers ook getoetst dient te worden, in de tijd lijkt te zijn toegenomen: overigens wil dat niet zeggen dat er in dit opzicht geen wensen meer te formuleren zouden $z 1 j n$, lntegendeel. Wel blijkt dat dergelijke wensen vertaald kunnen worden in te beantwoorden vragen, warbij deze antwoorden in practisch handelen omgezet kunnen worden. Definitieve conclusies t.a.v. het functioneren van de gehele GGz mogen n.a.v. de hier gepresenteerde deelstudies niet getrokken worden. Wel zouden wij lets meer zekerheid verkrijgen, indien b. $v$. in die middelgrote gemeente in het noorden van Nederland soortgelijke ontwikkelingen als in het zulden te constateren zouden zijn. Toch moet gewarschuwd worden tegen het al te gemakkelijk, te snel generaliaeren n.a.v. reglonale deelstudies: uiteindelifk kan alleen het vertichten: van analoge studieg in meer delen van Nederland darto een gerechtvardige anleiding zijn. Wat dat betreft moeten ve wachten op de resultaten van nleuwe reglsters en/of op resultaten van anderssoortige onderzokingen elders in Nederland. 


\subsection{Inleiding}

In dit hoofdstuk wordt en ultwerking gegeven vanuit de in hoofdstuk 7 gedane constatering dat niet iedere categorle in de samenleving eenzelfde kans heeft met de GGZ in anraking te komen.

Dit hoofdstuk is opgebouwd uit twee onderdelen. In het eerste wordt op een drietal wijzen per buurt van en stad van ongeveer 110.000 inwoners het incidentiecijfer bepald. Bovendien worden de aldus verkregen cijfers voor o.a. de leeftijdsopbouw per buurt gecorrigeerd.

In de tweede paragraaf worden deze gecorrigeerde cijfers (SMR's) vergeleken met een antal andere zaken gemeten op buurtniveau, die op hun beurt ook lets vertelien -als indicator-over de qualiteit van het bestaan (c.q. over pogingen samengestelde gellfkheld te realiseren).

\subsection{Maatschappe1ijke kwetsbaarheid en angemelde morbiditeit}

In deel I heb ik beredeneerd dat die groepen in de samenleving die op een punt -wat betreft een "sociaal goed"-compensatie nodig hebben, ook een meer dan toevallige kans lopen voor andere 'sociale goederen' compensatie te behoeven. 
De sociale en ruimtelifke sprefding van pogchiatrische morbiditeit H.J.E.R. Hamers ${ }^{*}$

\section{Inlelding}

Geluk en ongeluk - isselend uftgedrukt in termen als welzijn, gezondheid, het ontbreken van allerhand problemen, etc. - blijken niet met behulp van een dobbelsteen over de bevolking verdeeld te zijn.

Zo blijkt de Amsterdamse populatie opgesplitst naar buurten een grote variatle te kennen wat betreft een drietal gezondheidsindicatoren, te weten sterfte, ziekenhuisopname en langdurige arbeidsongeschiktheid (Habbema e.a., 1980 en van den Bos e.a., 1981): een relatie tussen soclaal-economische status (SES) en gezondheid blijkt aanwezig. Voor Rotterdam (Verdonk, 1979) werd op een soortgelijke wijze een verband geconstateerd tussen SES en geestelijke gezondheid (beide indicatoren werden ook weer op buurtniveau gemeten). Hoewel Bosma (1975) voor Nijmegen -een tad anzienlijk minder grootsteeds als Rotterdam en Amsterdam- antoonde, dat daar een a-typisch patroon wat betreft de psychiatrische opnamen voorkwam, was er voor ons de nodige twijfel of wif voor een provinciestad als Mastricht (met ongeveer 110.000 inwoners) grote (en stabiele) verschillen tussen geografische eenheden wat betreft de aangemelde psychiatrische morbiditeit zouden aantreffen. Immers, Maastricht kent nlet alle vormen van de rand(groot)stedelijke problemen en hoewel de populatie in $z i j n$ geheel relatief achtergesteld is, zijn de sociaal-economische tegenstellingen niet zo groot (zie ook Social Cultureel Planburo, 1980 en van Wagenberg, 1982).

Ondat de hlerboven angehalde literaturur grotendeels gebaseerd is op administratief bepalde antalien $-d . w . z$. dat op indirecte manier ultspraken omtrent de (geestelijke) gezondheidstoestand van subpopulaties gedaan worden-, is voorzichtigheid geboden. Zo werd onlangs geconstateerd dat juist die categorieln die het meest geplagd worden door een slechte geestelifke gezondheid het minste met de psycho-sociale hulpverlening in aanraking komen (Raats e.a., 1987). Naar aanleiding hiervan zijn twee opmerkingen te maken. De cerste is inhoudelijk van aard: als de geestelijke gezondheidszorg (GGZ) de categorleên met de slechtste geestelifke gezondheid het minst berelkt, dan is zij kennelifk slecht op haar taak berekend.

* als socioloog verbonden a de vakgroep Soclale Psychiatrie van de Rijksuniversiteit Limburg. 
De tweede opmerking is methodisch van aard: Indlen de ultspraak van Rats en de zijnen algemeen geldig $\mathrm{Is}$, dan leert het administratief bepalde (Incidentie- en prevalentie-) ciffer ons 'als indlcator' niets omtrent de verdeling van de werkelijke morbiditeit in de populatie. Ook het filtermodel van Goldberg (Goldberg H Hxley, 1981) geeft steun an de uitspraak dat de angemelde morbiditelt geen goede weergave behoeft te zijn van de spreiding van de verkelijke morbiditeit. Immers vanuit dit model mag verondersteld vorden, dat niet ledereen in de populatie -bif overenkomstige pathologle- eenzelfde kans heeft met de GGZ in contact te komen. Achtereenvolgens kan if een discrepantie tussen pathologle: en "gerealiseerde behoefte"

ontstaan door l.) hulpzoekgedrag ( 0. . rlchting le lija en GGZ-sector) 2.) (verwijs)gedrag van le lifns functionarisaen en 3.) GGZ-factoren (zoals afstand tot de populatie, GGz-omvang, veronderstelde effectiviteit, image, p.r.-aktiviteiten, etc.). Toch zijn er redenen te over ons vooralsmog te beperken tot de angemelde morbiditeit (o.a. vanwege de beschikbaarheld van deze en niet van andere data, andere data die bovendien slechts op een kostbare wije te vergaren zouden $\mathrm{zijn}$ ).

De interesse in administratieve incidentiecijfers ontstond uit twee overwegingen. In de eerste plaats ondat daarin de (gerealiseerde) behoefte an GGZ tot uitdrukking komt en zodoende tot uiting komt voor wie de GGZ feitelijk werkt. Bovendien - in de tweede plaats-als blijkt dat de (gerealiseerde) behoefte in sterke mate anwezig is in categorieen die in bevolkingsonderzoekingen als risicogroepen gesignaleerd worden, dan mogen wij veronderstelien dat er en samenhang bestaat tussen behoefte an GGZ en de mate warin er in subpopulaties psychiatrische pathologie anwezig is. Indien deze latste veronderatelling onderbouwd kan worden, dan zijn wellicht de (sociale) determinanten inzake geestelijke ongezondheid te achterhalen en kunnen if nleuwe hypothesen genereren, c.q. ter toetsing van oudere hypothesen material verschaffen.

De vragstelling "hoe is de sociale en rulmtelijke sprelding van de angemelde psychiatrische morbiditeit" zal hier an de orde komen: over hoe deze angemelde apreiding zich verhoudt tot de ware marblditeit zal hier beslist niet het latste woord gezegd worden.

Methode

In feite is onze werkwijze erop gericht om de top van de ijsberg te beschrijven - het gedeelte van de psychiatrische morbiditeit dat boven water, bij de GGZ, kont- en daamee uitspraken te doen over de totale ijsberg. Hoewel wif geen informatie hebben over datgene an marbiditeit dat niet bif de GGZ verschijnt, hebben wij de mogelijkheid te bezlen hoe de verdeling over de echelon in de GGZ zelf ultvalt: m.a.w. Wij hebben de mogelijkheid tot op zekere hoogte de stand van de vatersplegel te manipuleren. Immers als top van de $1 \mathrm{j}$ sberg kunnen if het incidentleciffer nemen welke amenhangt met 
1.) alleen de intramurale GGZ, 2.) alleen de semi-en de intramurale GGZ en 3.) alle GGZ-voorzleningen, dus de extra-, de semi- en de intramurale GGZ. In figuur 1 ziet de metafoor er als volgt uit:

Elguux 1.

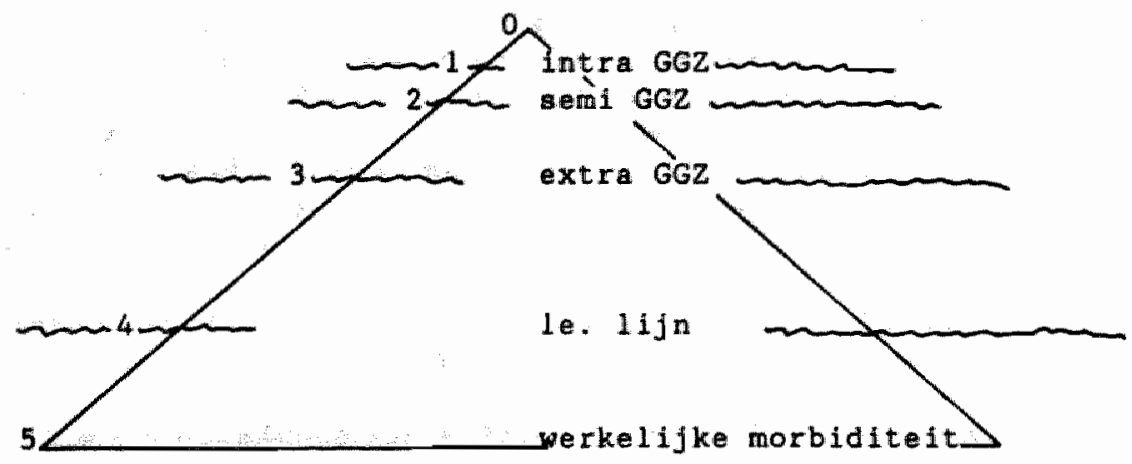

Ontrent 'waterspiegel' 4 en 5 hebben wij geen informatie, maar de veronderstelling is dat indien er een rechte $11 \mathrm{jn}$ gat door de punten $0,1,2$ en 3 die 1 ijn zijn weg recht zal vervolgen door de punten 4 en 5. Anders gezegd, indien de incidentlecijfers gemeten voor diverse aubpopulaties op de punten 1,2 en 3 met elkaar samenhangen gaan if or vooralsnog van uit dat $z i j$-in relatieve zin-goede uitspraken doen inzake de werkelijke morbiditelt in die subpopulatie. Deze benadering is elders (DeVries e.a., 1986) uitgebreider verantwoord.

Vooreerst hebben wif besloten ons onderzoek te beperken tot de stad Maastricht (ongeveer 110.000 inwoners), ondat zodoende de afstand tussen de populatie en de GGZ -vrijwel geheel in Maastricht aanwezigconstant gehouden wordt. Welliswaar kost het vanuit enkele buurten lets meer tifd dan gemiddeld om de GGZ -of een onderdeel daarvan- te bereiken, maar in een stad die op een willekeurig moment van de dag in oen willekeurige richting in ongeveer tien minuten per auto te 'doorkrulsen' is, mogen wij annemen dat afstand geen rol zal spelen voor de populatie om al dan niet gebrulk van de GGZ te maken.

Bekend is dat een antal categorfeern-gevormd met behulp van eenvoudige demografische variabelen als leeftijd en burgerlijke staat - meer dan anderen gebruik van de GGZ maken (Glel ten Horn, 1981; Hamers \& Driessen, 1986): wellicht kennen deze categorieen ook meer pathologie, althans daarvoor is in diverse bevolkingsonderzoekingen steun te vinden (Henderson e.a., 1981; Offerhaus, 1984 en Hod lamont e.a., 1986).

Binnen onze onderzoekspopulatie zullen vooreerst de aantallen (per 1000 inwoners in de verschillende categorieën) berekend en 
weergegeven worden: verwolgens kan verwacht worden dat vanwege een specifieke demografische opbouw van een subpopulatle de (gerealiseerde) behoefte an GGZ vanuit een antal ruimtellfke eenheden groot zal zijn. W1j wensen subpopulaties met elkar te vergelifken warbif wij niet zozeer geinteresseerd zifn in de invloed van een specifieke populatieopbouw, mar warblj deze invloed ulteraard niet ontkend mag worden. Daarom hebben wij ons Incidentleciffer omgewerkt naar een SMR (standardised morbldity rat 1o) ofwel indirect gestandaardiseerd voor leeft $1 \mathrm{jd}$ en burgerlijke staat warbif de totale populatle van Mastricht en het daarbij per burgerlijke stat en per leeftijdscategorie behorend incidentieciffer als referentie heeft gediend (zle o.a. Sturmans 1983 en v.d.Mas \& Habbema, 1981 ).

De administratieve incidentiecijfers als hierboven bedoeld $z i f n$ met behulp van een gevalsregister voor de GGZ bepald. De mogelijkheden van een dergelijk register zijn breed en liggen op het vlak van zowel Bezondheidszorgonderzoek alsook epidemiologisch onderzoek (Glel \& ten Horn, 1976). In het register zijn de gegevens opgeslagen van personen woonachtig in een orschreven gebied en in contact met de GGZ; deze gegevens worden zodanig opgeslagen dat patientstromen en patiëntcarrières gereconstrueerd kunnen worden. Ook adminlstratieve incidentie- en prevalentiecijfers zijn alleen m.b.v. deze onderzoeksmethode vast te stellen.

Het register is gestart op 1 januari 1981 en keek daarbij drie maanden in de tijd terug. Onze incidentieteliing hebben wij op 1 Januari 1982 laten starten en loopt door $t / m 31$ december 1985 . Dat w1 zeggen dat iedereen (woonachtig in Mastricht), die gedurende de laatste drie maanden van 1980 on 1981 niet en in de periode van 1 Januari 1982 tot 1 januari 1986 wel met de GG2 in contact kwam, in het incidentiecijfer werd opgenomen. Vervolgens hebben wij drie soorten incidentieciffers bepaald. Het eerste incidentiecijfer is gebaseerd op een definitie van de GGZ warbij alle GGZ-voorzieningen betrokken zijn (voor en overzlicht van de bij het register betrokken voorzleningen zie Hamers e.a., 1986), het tweede incidentieciffer is gekoppeld an een definitle van de GGZ warbij alle seni-.en Intramurale GGZ-voorzieningen als GGZ zijn geoormerkt: Tensllate het derde Incidentiecijfer dat -alleen intramurale GGZ-voorzieningen- in feite atat voor alle eerste psychiatrische opnamen. Deze drie Incidentiecijfers zijn gestandaardiseerd en geindexeerd en worden per buurt weergegeven. Hierbij is gebruik geraakt van de gegevens per buurt zoals die verkregen konden worden van de afdeling onderzoek en Statistiek van de gemeente Maatricht. De werkwifze aangande het gtandardiseren is als volgt in zijn werk gegaan: per leeftijds- en per burgerlijke staat categorie in voor geheel Mastricht bekend hoeveel incidentiegevalien er zijn. Per buurt -vanult het werkelijk antal inwoners per categorie in de buurtpopulatie- is dus te berekenen hoeveel incidentiegevallen er (per categorie) op basis van het stedelijk getal verwacht mogen worden en het geobserveerd antal 
(per categorle) is ulteraard bekend: ult die verhouding komt de (1ndirect) gestandaraliseerde morblditeitsratio naar voren.

\section{Resultaten}

Het feitelijk gemidield incidentieciffer (6738 incidentiegevallen gedurende 4 jaren) voor Maasticht bedraagt 14.77 per 1000 inwoners per jaar: enkele kleinere buurten (kleine populatie, een industrieterrein, e.d.) zijn bulten beschouwing gelaten, zodat onze data betrekling hebben op 34 buurten. Van 4.87 van de mastrichtse incidentlegewallen was de burt onbekend of betrof het een wan de kleinere verder bulten beschouwing blijvende buurten (netto blijkt dan 3.57 onbekend): het incidentieciffer over de 34 buurten (gemiddeld 113.893 inwoners) bedraagt 14.08 per 1000 inwoners per jaar (6414 incident legevallen).

Alvorens onze data nader te analyseren was onze eerste zorg Bericht op de mate warim onze gegevens per buurt stablel in de tijd zouden zifn. Ulterard zullen over langere perioden $-b: v$. een buurt die verpaupert of war zich juist stadsvernieuwingsprocessen afspelenveranderligen kunnen plaatsvinden: echter gedurende kortere perioden moet vooreerst verwacht worden dat er leder jaar uit en buurt ongeveer evenveel nieuwe gevallen zullen optreden.

In tabel 1 is afleesbaar dat de stabiliteit over die periode van vier Jaren groot is: m.a.w. per buurt per jaar ziet de GGZ ongeveer evenveel nieuwe patienten (in de zin van incidentiegevallen).

Tabe1 1. De correlatiecoefficienten tussen de absolute a antalien incidentiegevalien (a1le GGZ-voorzleningen) per buurt ( $N=34)$ en per jaar.

\begin{tabular}{lccc}
\hline & 1983 & 1984 & 1985 \\
\hline 1982 & $0.92 *$ & $0.90 *$ & $0.91 *$ \\
1983 & - & $0.96 *$ & $0.95 *$ \\
1984 & - & - & $0.96 *$ \\
$*$ significant $<0.01$ & &
\end{tabular}

2oals al gezegd heeft niet ledere categorie in de populatie evenveel kans om met de GGZ in anraking te komen: indien wij de incidentieciffers per buurt willen bezien dan zal hiermee rekening gehouden moeten worden. In tabel 2 is aangegeven dat controleren op leeftijd en burgerlijke staat noodzakelljk is; opvallend is overigens dat de getallen per 1000 inwoners in de onderscheiden categoriezn voor de drie incidentlecijfers parallel lopen. Zo hebben Bescheiden personen 
een grote kans met alle voorzieningen in aaraking te komen, maar is ook het incidentieciffer wan de gescheidenen wat betreft intramurale voorzieningen hoog. Buurten war b.v. veel gescheidenen en bejaarden wonen zullen om die reden hogere incidentieclffers hebben: standardiseren voor leeftijd en burgerlifke staat is dus noodzakelifk.

Tabel 2. Voor geheel Maastricht de antallen per 1000 inwoners voor drie incidentiecifferg (1982-1985) voor de gehele populatie, naar leeftijd en naar burgerlijke stat weergegeven als gemiddeld ciffer per $j a a r$.

\begin{tabular}{|c|c|c|c|}
\hline categorie & $\begin{array}{l}\text { Incidentiec } \\
\text { gehele GGZ }\end{array}$ & $\begin{array}{l}\text { Jfer per } 1000 \text { in } \\
\text { semi/intra GGZ }\end{array}$ & $\begin{array}{l}\text { voners } \\
\text { intra GGZ }\end{array}$ \\
\hline $\begin{array}{l}\text { ongehuwden } \\
\text { gehuwden } \\
\text { gescheiden } \\
\text { weduwstaat }\end{array}$ & $\begin{array}{l}12.136 \\
12.740 \\
32.672 \\
18.248\end{array}$ & $\begin{array}{l}2.594 \\
2.900 \\
8.914 \\
5.047\end{array}$ & $\begin{array}{l}1.127 \\
1.466 \\
4.780 \\
4.807\end{array}$ \\
\hline $\begin{array}{l}0-19 \mathrm{fr} . \\
20-39 \mathrm{jr} . \\
40-69 \mathrm{jr} . \\
70 \mathrm{fr} . \mathrm{e.o} .\end{array}$ & $\begin{array}{r}9.673 \\
17.471 \\
10.749 \\
23.197 \\
\end{array}$ & $\begin{array}{l}2.271 \\
3.020 \\
2.698 \\
7.433 \\
\end{array}$ & $\begin{array}{l}0.085 \\
1.274 \\
1.751 \\
6.477 \\
\end{array}$ \\
\hline
\end{tabular}

FIGUUR 2.

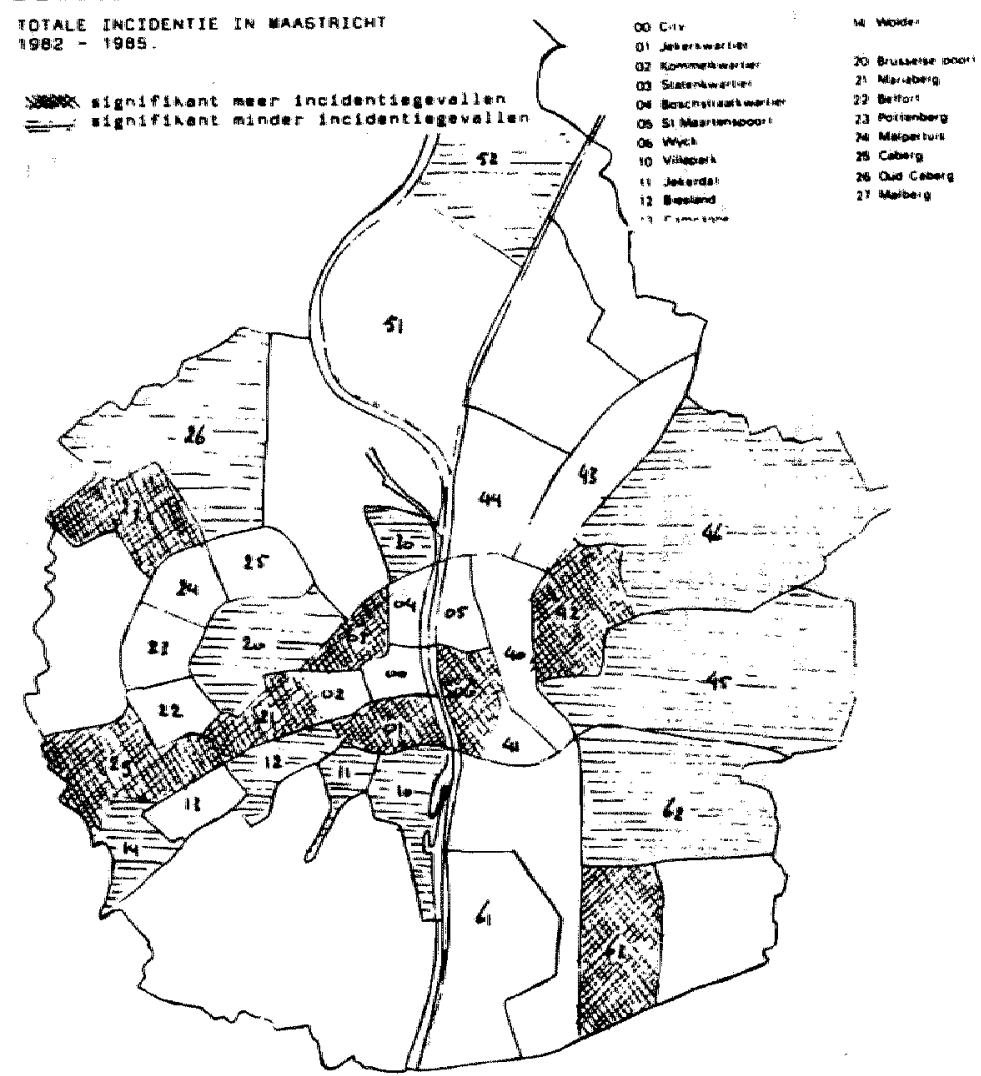


Tabel 3 geeft de gestandaardiseerde morbiditelts ratio's (alle voorzieningen SHRe; cemi- en intramurale voorzieningen SMRs en Intramurale voorzieningen SMRI) voor de afzonderlijke buurten. Op het eerste gezlcht blijkt al dat de drle SHR's onderling samenhangen, terwijl uit de tabel -zle ook figuur 2- duldelijk blijkt welke butrten significant meer incidentiegevalien dan verwacht kennen, danwel juist significant minder: het toetsen is geschled op een wize als door $v$. d. Mas o Habbema (1981) angegeven.

Tabel 3. De drie gestandaardiseerde morbiditeitsratio's en de absolute antalien incidentiegevallen.

\begin{tabular}{|c|c|c|c|c|c|c|}
\hline BUURT & SMRe & $(\mathrm{N})$ & SMRS & (N) & SMRI & $(\mathrm{N})$ \\
\hline$\overline{c i t y}$ & 120.91 & 113) & 98.88 & 21) & 100.92 & 11) \\
\hline jekerkwartier & $166.58 * C$ & 153) & 137.33 & 31) & 165.32 & 22) \\
\hline komme 1kwartier & 106.64( & 131) & 135.76 & 43) & 162.80 & 33) \\
\hline statenkwartier & $160.46 *($ & 152) & 135.01 & 30) & 139.64 & 17) \\
\hline boschstratkwartier & 114.410 & 76) & 94.98 & 14) & 148.69 & 11) \\
\hline martenspoort & 120.78 & 115) & 140.03 & 32) & 148.79 & 19) \\
\hline$w i f \mathrm{ck}$ & $138.20 *($ & 164) & 231.21 & 62) & 224.15 & 31) \\
\hline v111 apark & $62.06 *($ & 109) & 45.62 & 19) & 52.85 & 12) \\
\hline jekerdal & $60.28 *($ & 48) & 63.60 & 12) & 68.89 & 7) \\
\hline b1esland & $68.89 *($ & 69) & 61.21 & 15) & 85.09 & 12) \\
\hline campagne & $06.36 \%$ & 74) & 119.66 & 26) & 144.24 & 19) \\
\hline wolder & $56.89 *($ & 56) & 45.41 & 10) & 29.61 & 3) \\
\hline brusselse poort & $87.13 *($ & $224)$ & 61.31 & 38) & 55.87 & 20) \\
\hline mariaberg & $114.40 * 1$ & 321) & 143.03 & 97) & 131.19 & $50)$ \\
\hline belfort & 88.95 & 163) & 61.20 & 26) & 72.81 & 16) \\
\hline pottenberg & 96.70 & $179)$ & 117.24 & 50) & 125.05 & 27) \\
\hline malpertuis & 93.98 & 161) & 109.71 & 44) & 85.99 & 18) \\
\hline caberg & 110.37 & 246) & 130.20 & 68) & $121 \cdot 30$ & 33) \\
\hline oud caberg & $72.87 *($ & 75) & 29.43 & 7) & 42.75 & 5) \\
\hline malberg & $132.26 *($ & $528)$ & 159.52 & 147) & 112.21 & 51) \\
\hline daalhof & $117.29 *($ & $548)$ & 87.51 & 92) & 79.35 & 39) \\
\hline bosehpoort & $58.25 *($ & 47) & 50.05 & 10) & 69.06 & 8) \\
\hline w Ifokerpoort & 103.82 & 223) & 110.30 & 57) & 120.01 & 35) \\
\hline kerpoort & 110.83 & 165) & 111.66 & 39) & 91.59 & 17) \\
\hline oostermaas & $127.56 *($ & $393 i)$ & $149.29 *$ & 109) & 109.85 & 43) \\
\hline nazareth & 96.231 & 212) & 104.83 & 54) & 91.16 & 25) \\
\hline 1 imme 1 & 97.77( & 123) & 76.65 & 22) & 48.10 & 7) \\
\hline scharn & $64.48 *($ & 18.4) & 65.29 & 44) & 76.88 & 2B) \\
\hline amby & $85.35 *($ & 211) & 89.95 & 51) & 95.93 & 27) \\
\hline borgharen & 96.181 & 114) & 74.87 & 20) & 70.46 & 9) \\
\hline 1tteren & 68.861 & 5.4) & 54.88 & 10) & 51.44 & 5) \\
\hline heugem & 100.23 & 158) & 114.31 & 41) & 125.85 & 22) \\
\hline heer & $71.42 *($ & 299) & 71.15 & 68) & 77.84 & $37)$ \\
\hline de heeg & $142.61 *($ & $526)$ & 118.92 & 95) & 74.45 & 24) \\
\hline MAAS & \multicolumn{2}{|c|}{$100.00(6414)$} & \multicolumn{2}{|c|}{$100.00(1504)$} & \multicolumn{2}{|c|}{$100.00(743)$} \\
\hline S.D. & 28.69 & & 41.86 & & 42.27 & \\
\hline
\end{tabular}


De toetsing is sterk afhankelijk van het aantal govallen per buurt, waardoor de SMRs en de SMRI nergens, een enkele keer uitgezanderd, Ignificant blijken af te wijken.

In tabel 4 zifn de correlatiecoefficienten tussen de drie SHR's weergegeven; hieruit blijkt dat zlj sterk samenhangen en dat dit -zeker wat betreft de correlatie tussen SMRe en de andere twee SMR"sniet toe te schrifven is an het aantal 'gezamenlijke" incldentiegevalien. Anders gezegd de drie SMR $11 \mathrm{Jken}$ in sterke mate hetzelfde op buurtniveau te meten.

Tabe 1 4. De correlatiecoefficlenten tussen de drie SMR's.

\begin{tabular}{lccc}
\hline & SMRs & SMRI & $\begin{array}{c}\text { gebaseerd op a antal } \\
\text { incidentiegevalien }\end{array}$ \\
\hline SHRe & $0.78 *$ & $0.66 *$ & 6414 \\
SMRs & - & $0.88 *$ & 1504 \\
SMRi & - & - & 743 \\
\hline * significant le $<0.01$ & \\
\hline
\end{tabular}

Tabel 5. De correlatiecoüficienten: de SMR $s$ en de geobserveerde aantalien per 1000 inwoners (leeftifd en burgerlijke staat).

\begin{tabular}{|c|c|c|c|c|c|c|c|c|}
\hline & on & gehuwd & gesch. & $7 \mathrm{st}$. & $0-191$ & $20-391$ & $40-691$ & 7010 \\
\hline 1 & $0.78 *$ & $0.76 *$ & 0.26 & $0.43 \star$ & $0.72 *$ & $0.89 k$ & $0.67 *$ & $0.57 \hbar$ \\
\hline $\mathrm{MRE}$ & $0.53 *$ & $0.45 *$ & 0.20 & $0.55 *$ & $0.49 \star$ & $0.79 *$ & $0.44 *$ & $0.57 *$ \\
\hline SMR 1 & $0.55 *$ & 0.26 & 0.03 & $0.52 \star$ & $0.48 *$ & $0.64 *$ & 0.25 & $0.48 *$ \\
\hline
\end{tabular}

* significant $<0.01$

In tabel 5 zijn de correlaties tussen de SMR"s enerzijds en de geobserveerde antallen per 1000 voor enkele onderscheiden subpopulaties anderzijds opgenomen. Hieruit mag geconcludeerd worden -gezien de hoge correlaties uitgezonderd voor de geschelden populatie- dat ongeacht de hoogte van de SMR op buurtnivo telkens dezelfde categoriegn in relatleve $z i n$ onder- danwel oververtegenwoordigd zijn. Ofwel er blijkt en lgemene buurtfaktor anwezlg die de drie SMR's hoog danwel laag doen zijn.

\section{Discussie}

Gebleken is dat 1.) het antal incidentlegevalien per buurt over een perlode van vier jaar atablel is, 2.) de drle gestandaralseerde morbiditeitsratio"g nau met elkar samenhangen c. g. hetzelfde $11 \mathrm{jken}$ te meten en er mogelijk een onathankelijke buurtfaktor anwezig is die 3.) ervoor verantwoordelijk geacht kan worden dat gestelijke Bezondheid -uitgedrukt als gerealiseerde behoefte- niet toevallig over de populatie van Mastricht verdeeld is. Ten elote 4) bleken en antal categorlešn oververtegenwoordigd: darmee konden eerdere 
bevindingen gereplicterd worden.

U1t en reeks opeenvolgende onderzoekingen (Brook \& Hamers, 1985. Hamers Brook, 1986; Hamers \& Drlessen, 1986) groelt bif ons een steeds toenemend vertroumen in de geldigheid van administratieve incldentie-ciffers a is indicatoren voor de psychische morbiditeit in aubpopulaties. Deze geldigheld is echter alleen aanezig onder anname van een ge11jk (quantitatief en qualltatlef) hulparanbod voor de (sub)populaties.

De verdeling van de angemelde psychiatrische morbiditelt blijkt niet volgens de concentrische zone-theorie anwezig. Wel blifkt dat de centrumbuurten een hoge norbiditeit kennen; dat geldt echter ook voor een antal buurten dle verder van het centrum of zelfs aan de rand van de stad gelegen zijn. Over de gehele linie lijkt een duidelijk verband met de social-economische status van de buurten aanwezig: dit verband $\mathrm{za} 1$ in een volgend artikel uitgewerkt worden.

noot 1 .

Onder gerealiseerde behoefte verstaan wij dat deel van de "psychische ellende dat door de omgeving, de le. lifns voorzieningen en de patient als zwar genoeg beleefd wordt om door de GGz behandeld te worden en warbij aan de beoogde behandeling kennelijk op voorhand enig vertrouwen is gegeven.

\section{Literatuur}

Bos, T. van den, A. Lau-IJzerman, J.D.F. Habbema C P.J. van der Maas: Ongezondheld in de grote stad (I \& I). Medisch Contact, $1981 ; 12$ : 13: $335-340,385-89$.

Bosma A. De ruintelijke spreiding van klinisch psychiatrische patienten in Nijmegen. Tijdschrift voor Psychiatrie, 1975; 17 (4): $273-282$.

Brook F.G. \& H.J.F.R. Hamerg: GGZorg gepeild. Een vergelijkend onderzoek met behulp van twee Registers voor de Geestelijke Volksgezondheid. Tijdschrift voor Psychiatrie, 1985; 27 (2): $115-127$.

DeVries M.W., H.J.F.R. Hamers C. Sturmans: The use of the case register in making epldemiological research more cost-efficient. In: G.H.M.M. ten Horn, R. Glel, W.H. Gulbinat \& J.H. Henderson (EAs). Psychlatric Case Reglsters in Public Health, 1960-1985. Elsevier Science Publishers BV, 1986.

Gie1, R \& G.H.M.M. ten Horn: Een psychlatrisch reglster als basis voor planning. Tijdschrift voor Sociale Geneeskunde, 1976; 54 : 148-153.

Giel R. G.H.M.M. ten Horn: De verhouding tussen hulp-vraag en -aanbod: rislcogroepen in de GGZ. Tijdschrift voor Psychiatrie, $1981 ; 23: 504-521$.

Goldberg, D. G P. Huxley: Mental illness in the community. London, 1981 .

Habbema, J.D.F., T. van den Bos, A. Lau-IJzerman C P.J. van der Mas: Onderzoek nat verschilien in sterfte, ziekenhuisopname en langdurige arbeldsongeschiktheid tussen buurten in Amsterdam. Tifdschrift voor Sociale Geneeskunde, 1980; 58: 101-106. 
Hamers H.J.F.R. G G.A.M. Driessen: De geestelijke gezondheidszorg en haar risikogroepen. Tijdschrift voor Sociale Gezondheidszorg* 1986; 64, nr. 17: 562-567.

Hamers H.J.F.R., M.A.J. Romme \&.W. deVries: Resistance, Prlvacy and technology: Comments on the negotiations to establish the case register in Mastricht. In: G.H.M.M. ten Horn, R. Glel, H.H. Gulbinat \& J.H. Henderson (Eds). Psychiatric Case Reglsters in Public Health, 1960-1985. Elsevier Sclence Publishers BV, 1986.

Hamers H.J.F.R. \& F.G.Brook: De GGZorg in het noorden en zulden des lands in 1981. Tifdschrift voor Psychiatrie, 1986; 28: 254-266.

Henderson, S., D.G. Byrne \& P. Duncan-Jones: Neurosls and the soctal environment. Canberra, 1981 .

Hodiamont, P., B. ter Helne, P. Hegendael, J. Furer $\mathbf{P}$. Peer: Psychiatrische en psychosociale problematiek: overeenkomst en verschil. Maandblad Geestelj.jke Volksgezondheld, 1986; nr.2: $128-144$.

Maas, P.J. van der \& J.D. Habbema: Standaardiseren van ziekte- en sterftecijfers: magelijkheden en beperkingen. Tijdschrift voor Sociale Geneeskunde, 1981; 59, nr.8: 259-270.

Raats G., R.Sanderman J.Ormel: Ongelijke kansen op geestelijke gezondheid(szorg). Verslag naar het voorkomen van risicogroepen ten anzien van de geestelijke gezondheid in Nederland. Vakgroep Medische Soclologle, Groningen, 1987.

Sociaal Cultureel Plaburo: S.C.P. cahier no. 14, 1980.

Sturmans F.: Epidemiologie. Theorie, methoden en toepassing. Dekker \& v.d.Vegt, Nijmegen, 1983.

Wagenberg H. van: Rangorde van sociale achterstand in de buurten van de gemeente Mastricht en van de gemeente Mastricht in vergelifking met een aantal Limburgse en Nederlandse gemeenten, Dienst Welzijnszaken Mastricht, 1982 . 
9.2.2.

Behoefte an GGZ in relatie tot amengeatelde gelijwheid

H.J.F.R.Hamers ${ }^{*}$

\section{Inlelding}

Het bepalen van de behoefte an (A)GGZ blijkt geen eenvoudige zaak. B1fl en Mastboom (1986) concluderen, dat bevolkingsonderzoekingen -het vaststellen in objektleve of in subjektieve zin van psychische ellende- ons op dit punt nlet verder brengen. Ook ij (o.a. DeVries e. 1986; Hamers Driessen, 1986) zijn van mening dat aan het loket -de geestelljke gezondhefdszorgvoorzieningen (GGZ)-voorlopig de beste indicatoren te vinden zijn, ondat daar blijkt wat de gerealiseerde behoefte is: d.w.z. dat deel van de "psychische - 1 lende" dat door de omgeving, de le lifnsvoorzleningen en de patient zelf als zwar genoeg beleefd wordt om door de GGZ behandeld te worden en warblj ar de beoogde behandeling kennelijk enig vertrowen wordt gegeven. Dat er tussen mogelijke behoefte en gerealiseerde behoefte en grote discrepantie anwezig is, mede ten gevolge van de werking van fllters tussen populatie en GGZ en ten gevolge van de omvang van de GGz (zie b.v. Goldberg \& Huxleg, 1981) behoeft hler nauwelijks vermeld te porden. De centrale vragg is echter of sommige groepen in de GGZ relatief oververtegenwoordigd $z 1 j n$, omdat de fliters op de en of andere wijze selectief werken of ondat zlf daadwerkelifk meer behoefte an GGZ hebben.

De inwalshoek die hier gekazen wordt om de behoefte an GGz te bespreken, komt voort uit het begrip 'samengestelde gelljkheid". Met dit begrip wordt weergegeven dat in onze samenleving ongelijkheid ten anzlen van sociale goederen weliswar anwezig is, mar dat diegenen die wat betreft een soclaal goed tekort komen, daarvoor gecompenseerd vorden. Een dergelifke compensatie kan echter niet zonder meer als een onverdecld genoegen beschouwd worden, ondat $z$ if als een inbreuk door het publieke in het prlve domein ervaren wordt.

op theoretische en empirische gronden is het zeer aanneemlijk dat individuen die wat betreft een sociasl goed compensatie behoeven -onder de heersende Ideologie van samengestelde gellfkheid (zie Koot ( Stegerhoek, 1986)-een gratere kans hebben ook wat betreft andere sociale goederen tekort te komen. Het is in deze zin dat verwacht mag worden dat categorle en die meer dan andere 'publiekelijk' gecompenseerd worden ook meer behoette zullen hebben an GGz; of zij daadwerkelifk meer gebrulk maken van die GGZ, hangt mede af van in hoeverre de GGZ har matschappelifke taak varmakt. Dat or wat betreft dit latste de nodige twijfels zijn, blijkt uit een recente constate-

* verbonden an de vakgroep Soclale Psychiatrie van de Rijksuniversiteit Limburg. 
ring dat die categoriekn die het meest geplagd worden door een slechte geestelifke gezondheld het minst met de psycho-soclale hulpverlening in a anraking komen (Raats e.a., 1987).

De hypothese die hier ter toetsing voorligt, is de volgende: de (reglonale) GGZ heeft tot taak (haar matachappe11Jk angedragen) samengestelde gelijkheid (op het terreln van de geestelijke volksgezondheid) te bewerkstelligen. Indien de categoriedn dle op andere terreinen (matschappelijke) ongelijkheld ervaren, danwel daarvoor gecompenseerd worden, in de GGZ-populatile ondervertegenwoordigd of evenredig vertegenwoordigd zijn wordt deze hypothese gescht te zijn verworpen.

De hypothese wordt getoetst door middel van (geaggregeerde) data die op een reglonale GGZ betrekking hebben; als de hypothese niet verworpen kan worden, wordt darmee dus en uitsprak gedan voor deze regionale GGZ en niet voor de GGZ in Nederland.

\section{Methode}

In de stad Mastricht hebben if gedurende een viertal jaren de nleuwe, bif de GGZ in behandeling gekomem, gevallen bepald met behulp van het reglster voor de geestelijke gezondheidszorg in de reglo Mastricht en ongeving. Dit register -opgezet naar analogie van het reglster in het noorden van Nederland (Giel ten Horn, 1976) -1s sinds 1 januar1 1981 operationeel en werd mede opgezet om replicatieen vergelijkende studies van de GGZ in verschillende reglo's mogelijk te maken (Brook \& Hamers, 1985 en Hamers \& Brook, 1986). A11een m.b.v. een gevalsregister voor de GGZ is het praktisch mogelijk am patientcarrieres, patientenstromen en (administratieve) incidentieen prevalentiecijfers vast te stellen.

Wif beperken ons hier tot de populatie in de stad Masstricht, ondat zodoende gecontroleerd wordt voor de afstand van de populatie tot de GGZ. Imners reeds lang is bekend dat het gebruik door de populatie van voorzieningen sterk athankelijk van do toegankelifkheid en berelkbarheid van de voorzieningen: afstand is hlerblj belangrifk.

Voar 34 buurten van Mastricht (enkele kleinere zijn bulten beschouwing gelaten) hebben wij over 4 jaren het gemiddelde inclidentieciffer per buurt berekend. Vervolgens hebben $1 \mathrm{~J}$ de $S M R$ (gestandaardiseerde morblditelts ratlo) berekend, wardoor een specifleke demografische opbouw (nar leeftijd en burgerlijke stat) geen invloed meer had. Een sterk vergrijsde buurt b.v. heeft vanwege de grotere kans om op hoge leeftijd met de GGz in kontakt te komen (Giel \& ten Horn, 1981; Hamers \& Drlessen, 1986) grotere anta11en incidentiegevallen: deze invloed werd zo ondervangen. De invloed van dergelifk geaggregeerde factoren blijkt voor kleine eenheden als buurten groot.

Tenslotte moet vermeld worden dat wj drie vegen gevolgd hebben om het incidentieciffer te bepalen (xie ook DeVries e.a 1986). Het eerste incidentieciffer omvat al diegenen die voor het eerst 
(gedurende $1982 \mathrm{t} / \mathrm{m} 1985 \mathrm{ma}$ in 1981 en de laatste drie maanden van 1980 'vrij van GGZ' te zijn geweest) met een willekeurige GGZ-voorziening (extra- of semi- of latramuraal) in aanraking komen. Het tweede on derde incidentiecijfer is op eenzelfde wijze vastgesteld mar dan respektievelijk voor de semi- of de intramurale GGZ en de intramurale GGZ. (De drie SMR's -dus de incidentieciffers als gestandaardiseerde morblditeits ratio's-blljken onderling sterk te correleren: $0.66,0.78$ en 0.88 , Zle ook Hamera, 1987.) In de resultaten sectie beperken wij ons hier tot de ratio's voor alle GGZ-voorzieningen (SMRe) en voor de combinatie semi-intramuraal (SMRs).

In samenwerking met de gemeente Maastricht, te weten de afdeling Onderzosk en Statistiek, de afdeling Onderwijs en de Sociale Dienst, het Gevestelijk Arbeidsbureau en het Medisch en Maatschappelijk Informatie Centrum (MEMIC) van de Rijksuniversiteit Limburg werden cen antal gegevens op buurtiniveau bijeengebracht; en weI demografische Begevens, de doorstroomcijfers betreffende het vervolgonderwifs, gegevens betreffende het schoolverzuim, de antallen uitkeringsgerechtigden ( $A B W$, RWW en WWV) en de aantallen werkzokenden. (Criminaliteits- en sterftecijfers bleken op dit moment nog niet voorhanden.)

Alle indicatoren zijn geindexeerd, waarbij wij zijn uitgegaan van de absolute antallen en deze gerelateerd hebben an de relevante referentiepopulatie. Vooreerst worden de scores op de indicatoren per buurt gegeven. Vervolgens zullen de resultaten van een clusteranalyse gepresenteerd worden.

\section{Resultaten}

In tabel 1 zijn de belangrijkste resultaten per buurt gegroepeerd weergegeven: twee maten voor wat betreft de gerealiseerde behoefte an GGZ (SMRe en SMRs), het aandel in de populatie van onvolledige gezinnen on wan gescheidenem, het schoolverzuim en de doorstroom naar HAVO-VWO, het antal uitkeringsgerechtigden ( $A B W, R W W$ en WWV) en het antal werkzoekenden. Bovendien stat in de tweede kolom het clusterlidmatschap weergegeven, welke resulteerde na de nog te bespreken clusteranalyse. Alle genoende indlcatoren zifn geindexeerd, warbif 100 voor gemiddeld staat, een hogere warde is ongunstiger dan gemiddeld -ultigezonderd de doorstroom nar HAVO-VWO- en een lagere waarde gunstiger dan gemiddeld. 
Tabel 1. Een weergave per buurt van het cluster wartoe de buurt behoort, van de SMRe, de SMRs en de rat $0^{\prime \prime}$ s betreffende het antal onvolledige gezinnen, gescheldenen, het schoolverzulm, de doorstroom naar HAVO-VWO, het antal uitkeringsgerechtigden ( $A B W, R W W$ en WWV) en het aantal werkzoekenden.

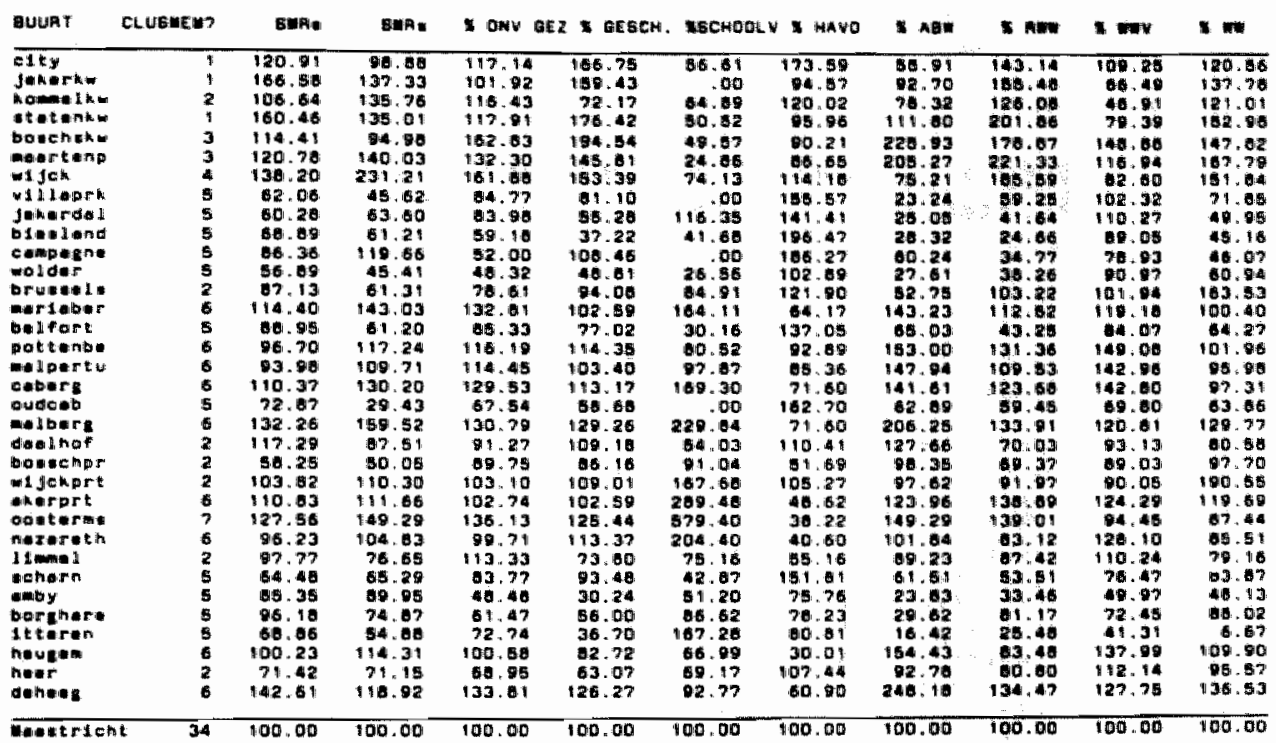

Over de gehele linfe blijkt global dat en ongunstige index op een indicator correspondeert met ongunstige warden op de overige indicatoren en andersom: uiteraard zijn de samenhangen niet perfekt. Over de tien indicatoren zoals die in tabel 1 zifn weergegeven is een clusteranalyse (SPSSX; methode Baverage; afstandsmat kwadratische euclidische warde; zie ook Norusis, 1986) uitgevoerd thet als doel te bepalen welke buurten wat betreft deze indicatoren bij elkar behoren. (De robuustheid van een methode ala clusteranalyse blifkt net altifd even goed: nar gelang de keuze van procedures en 
afstandsmaten blijken de resultaten nogal eens te varleren. Dat was voor ons en reden verschillende wegen tijdens het clusteren te bewandelen. De reaultaten bleken echter redelifk atabiel.)

Hier worden zeven cluster weergegeven: uit figuur 1 is af te lezen dat de clusters redelifk homogeen zijn en anel tot stand zijn Bekomen.

Flguur 1. Dendogram weergevend de wijze warop de butrten tot cluster bljeengevoegd $z i j n$.

Aencaled Olstance Cluster Comblne

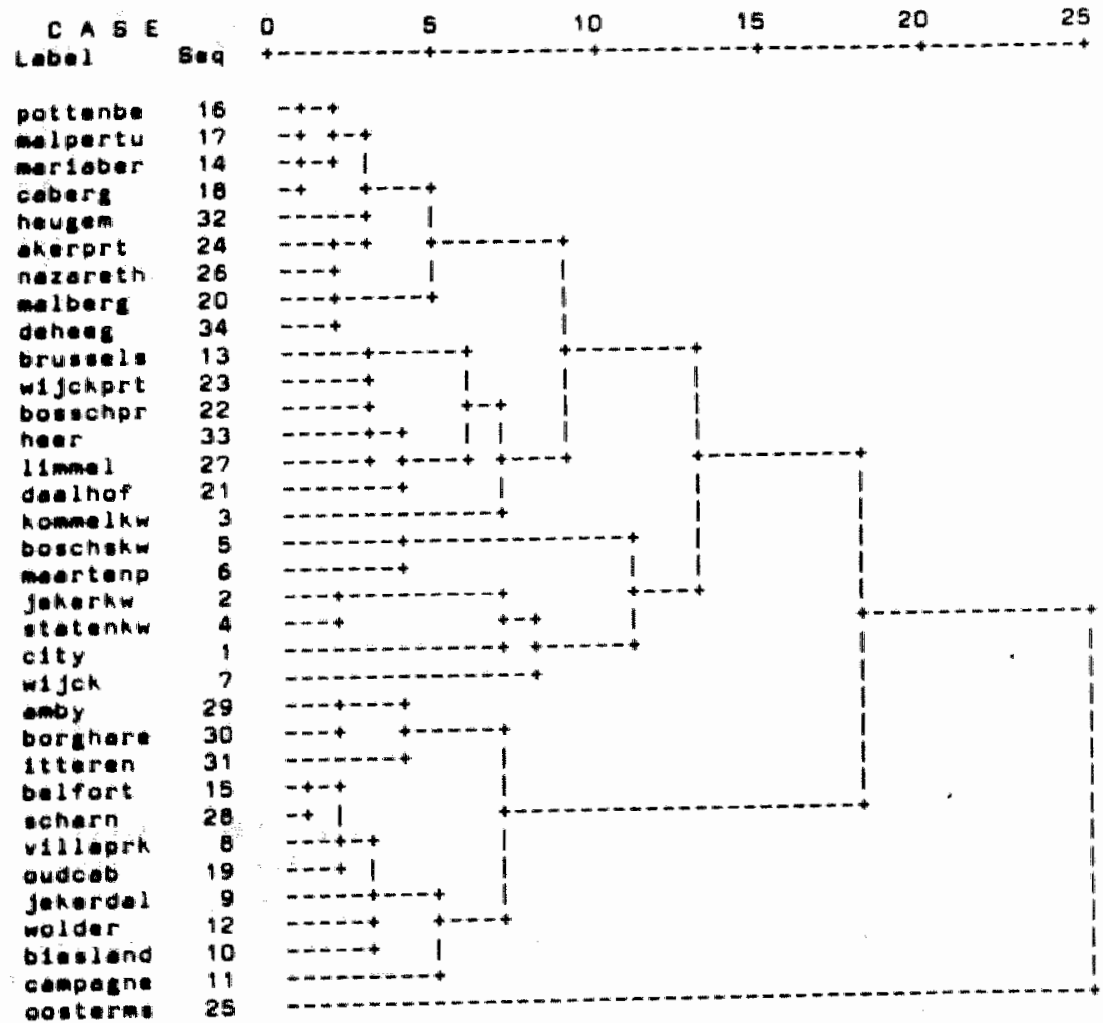


Tabel 2. De gemiddelden per cluster voor de indicatoren: betreffende de GGZ, de onvolledige gezinnen, de gescheldenen, het sehoolverzulm, de doorstroom nat HAVO-VWO, de uitkeringsgerechtigden en de werkzoekenden.

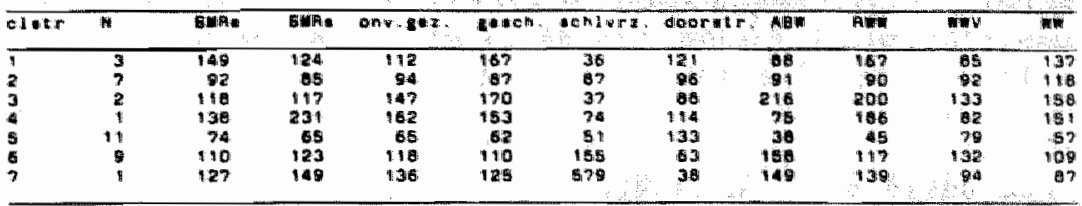

cluster 1 :

clty, jekerkwartler, statenkwartier.

cluster 2 :

kommelkwartier, brusselse poort, daalhof, boschpoort, wjckerpoort, 1 imme1, heer.

cluster $3:$ boschstraatkwartier, maartenspoort.

cluster $4:$ wjek.

cluster 5 .

villapark, jekerdal, biesland,

campagne,

wolder, belfort, oud-caberg, scharn, amby, borgharen, itteren.

cluster 6 : marlaberg, pottenberg, malpertuis, caberg, akerpoort, nazareth, heugem, de heeg.

cluster 7: oostermaas.

In tabel 2 is per cluster angegeven hoe de gemiddelde score per Indicator uitpakt en uit welke buurten leder cluster is opgebouwd. Het eerste cluster -een drietal binnenstadsbuurten- scoort hoog op de SMRe, het aantal gescheidenen en het aantal werkzoekenden, maar laag wat betreft het schoolverzuim.

Het tweede cluster -een zevental buurten-kent over de gehele linie gemiddelde scores op de indicatoren, terwijl het derde cluster - twee binnenstadsbuurten- op de meeste indicatoren ongunstig scoort (uitgezonderd het schoolverzuim). Het vierde cluster bestat uit cén (binnenstads)buurt: de hoge score op de SMRe en de vooral hoge score op de SMRs valien hier op. De scores op de overige indicatoren leveren een zeer gemêleerd beeld: enerzijds ongunstige indices voor wat betreft de onvolledige gezinnen, het antal gescheldenen, het aantal personen met een RWW-uitkering en het antal werkzoekenden, anderzljds weinig schoolverzuim, een hoge doorstroom nas HAVO-VWO en weinlg uitkeringsgerechtigden wat betreft de $A B W$ en de WWV.

Het grootste cluster -warin alle 'betere' buurten (11) zijn terecht gekomen- scoort op alle indicatoren duidelifk gunstiger dan gemiddeld. Daarentegen geft het daropvolgende cluster -met en negental buurten- een volledlg ander beeld: op alle indicatoren wordt ongunstig gescoord. Het laatste cluster -6én buurt- heeft enkele extreem ongunstige scores (SMRs, het schoolverzulm en de doorstroom nas het HAVO-VWO), terwijl ook voor de overlge indicatoren -ultgezonderd het antal WWW-ers en het antal werkzoekendenongunstige warden te zien zijn.

Inspektie van figuur $\mathbb{1}$ levert ons nog sallante informatie. Teruglopend $-d$. w. van zeven clusters naar én cluster-zien wij, dat llereerst (bij zes clusters) enkele binnenstadsbuurten (cluster 1 en 4) blj elkar gevoegd worden. Blj vijf clusters worden de twee 'arme' clusters ( 2 en 9) samengevoegd tot een groot cluster van 
aegten burten:

De volgende stap (vier clusters) levert een samenvoeging van alle binnenstadsbuurten (ultgezonderd het kommelkwartier) op, met over de gehele $11 j n$ ongunstige warden, hoewel de "onderwifsindicatoren" posltief blijken. Het tweede cluster bestaat uit fen buurt op vijwel alle Indicatoren (zeer) ongunstig scorend; en derde cluster omvat a11e betere' buurten van Maatricht met dienovereenkomstig gunstige acores. Vervolgens is en vierde cluster te onderschelden wat als gemideld arm" te typeren is.

Brengen 15 het antal clusters nog verder terug, dan ontstat een cluster (6en buurt) met extreem ongunstige scores, een tweede cluster bestaand ult alle "betere' buurten en een derde -een gemiddeld "arm"cluster.

Wat betreft de zeven clusters dienen enkele bevindingen gememoreerd te worden. Het 1 opvallend dat de binnenstadsbuurten met name in cluster 1 en 4, voor cluster 3 geldt dit in mindere mate- sterker geneleerd blifken, althans zo scoren op de indicatoren. Zo scoren de binnenstadsbuurten beter wat betreft de 'onderwijsindicatoren' en wat betreft de ABW en de WWV. Daarentegen scoren twee clusters (6 en 7 ) op viljwel alle indices (sterk) negatief en scoort cluster 5 op alle indicatoren (sterk) positief.

Discussie

Alvorens de discussie inhoudelifk ean te zetten is een wasschuwing op zijn plats. Deze geldt de resultaten betreffende het schoolverzuim. Immers julst omdat er in enkele buurten problemen op dit terrein zijn; is er een vergrootte aandacht voor een antal grotendeels buurtgebonden acholen. Met name het schoolverzulm in én buurt (Oostermas) is, als hier weergegeven, in verhouding te hoog.

De hier gepresenteerde resultaten kunnen op verschillende wijzen gelezen worden. Vanuit de optlek van de (psychiatrisch geschoolde) epldemioloog kan de diskuste over de spreiding ven psychische andoenlngen en de invloed darop van sociale factoren weer geopend worden. In grote $11 \mathrm{jn}$ zijn dan twe verklaringen mogelijk: de eerste luldt dat mensen dle (psychisen) zlek ziJn ten gevolge darvan afglifian nar en lagere sociale status (ofwel en premorblde persoonilfkheld hebben wardoor zif nlet die sockale status berelken d1. ${ }_{1} J$ op grond van andere kenmerken normaliter berelkt hadden). Deze personen konen terecht in butrten met en lage soclale status en d1t verklart de ruimtelijke prelding. Echter de processen van socile teruggang hebben tijd nodig, terwil wij hier uitgingen van Incidentlegevallen: $1 \mathrm{~J}$ het dat het incidentiegevallen in de GGZ betreft, dus de andoening kan van een eerder tijdstip zijn.

De tweede verklaring is nauw gellerd an de (algenene) stress-theorle en de onderzoeken rond de z.g. live-events. Lagere socilde klassen zouden al dan nlet in samenhang met persoonskenmerken meer te $11 j d e n$ hebben onder stress en bedreigende gebeurtenissen en dardoor meer psychische problemen hebben; deze sociale verdeling uit 
zich ook rulutelijt ten gevolge van processen as angegaven door Verdonk (1979) en verschlont dan gesplegeld in de rumbelike spreiding van angemelde psychlatrische norblditelt voot belde benaderingen 18 zowel theoretische nlook empirische gronc watg (ale ook Dohrenwend, 1986 ).

Oa deze kennel1jk onvruchtbare polumek te omellen, is her voor en andere optiek gekozen. In de context van de verzorgugestat (HA: warbj de tern lzorgzame samenleving wordt gezlen ws ean amendement op de verzorgingsatat) is samengestelde gelidkheld de concrete lnvulling geworden van het ldeal van een rechtvatuge abenleving." (Koot Stegerhoek, 1986, p.54) De hit getoonde bevindingen zijn te interpreteren als pogingen va de samenleving om de samengestelde rechtvamdigheid te bewerkstelligen, alj het dat ons metinstrumentariun vooral vanult een negatief gezichtsveld gesperationaliseerd werd. Echter, het is allesuns annemelis dat bijvoorbeeld hoogte van het inkonen en woonkonfort megatief gecorreleerd zin an de hier gehanteerde indicatoren betreffende de behoefte an GGZ.

De amenieving kent dus kennelijk mogelijkheden on ondervonden "ellende", zoals die t.g.v. menselijke verhoudingen, geleden verliezen, can gebrekkig sociaal netwerk, anwezige pathologit, ect. tot atand komen, te compenseren voor een categorie varbil op en punt gecompenseerd dient te worden, is de kans dat du voor andere zaken nod 18 is, groot.

De bevolking van Hastricht woonachtig in 34 buurten- is verdeeld over en groep 'betere' butren war weliawar (GGZ-)problemen voorkomen, mar kenneligk, is het leven er gemiddeld beter; over en tweede groep burten war de heterogenitelt groter blijkt en en ax anwezig is van mensen met meer en van mensen met minder probiemen dan elders. Resteren twee soorten burten, populaties i en soort bestaand uit gemiddelde burten met een gemiddeld antal problemen en een ander soort war zich op allerhand terreinen in het leven mer problemen dan elders voordoen. Overigens zijn het in globale zan ook deze vierde soort buurten war het soclaal-kultureel werk, de basiseducatie en het onderwijsvoorrangsbeleid -ook alle to bezlen als Instituties bedoeld om samengestelde gelljkheid te bewerkstiligenzich op richten.

Tenslotte 18 er een bevinding die frappeert en anieiding tot verder onderzoek geeft. Bekijken wij de SMR's dan blifkt det de "arme" clusters, de "arme' buurten ongunst $1 \mathrm{~g}$ scoren wat betreft de SMRe-dus vat betreft de ambulante GGZ-, mar nog ongunstiger wat betreft de SHRs (semi- en intramurale GGZ). De 'rifke' buurten geven een exact tegengesteld patroon te zien: dus nar verhouding nog minder intramurale zorg. Op dit punt is het trekken van conclusies voorbarig nader onderzoek met name gericht op de "patientcarriere" dient opgezet te porden, on te onderzoeken of de GGZ genelgd is om individuen ult lagere sociaal-economische klasien sneller intramuraal te behandelen en blj individuen ult hogere klassen dit juist langer ut of zelfs af te sellen.

Voorlopig kan voorzichtig geconcludeerd worden dat de reglonale GGZ, 
die hier onderzocht werd, aan haar maatschappelifke taak mede camengestelde gelljkheid te bewerkstelligen toekomt, maar ook dat het er op lljkt dat er tot op zekere hoogte sprake is van een qualteltsverschl in het aabod nas verschlliende sociaal economlache klassen.

\section{Literetur}

B1f1, R. I Jastboom: Van behoefte naar vraag. NCGV-reeks 89, 1986. Brook, F.6, an H.J.F.R. Hamera: GGzorg gepeild. Ben vergelifkend onderzoek met behulp van twee Reglsters voor de Geestelijke Volksgezondheld. Tijdgchrift voor Psychiatrie, $1985 ; 27$ (2): $115-127$

DeVrles, H.U., H.J.T.R. Hamers C . Sturmans: The use of the case reglater in making epldemiological research more cost-efficient. In: G.H.H.H. ten Horn, R. Giel, H.H. Gulbinat J.H. Henderson. Psychiatric Case Registers in Public Health, 1960-1985. Elsevier Science Publishers BV, 1986 .

Dohrenwend, B.P., Addendum: B.S. Dohrenwend, Social Status and Responsibility for Stressful Life Events. In: C.D. Splelberger I.G. Arason (eds.), Stress and Anxiety. Washington, Wew York, London, 1986.

Gie1, R. G.H.M.M. ten Horn: Een psychiatrisch register als basis voor planning. Tifdschrift voor Sociale Geneeskunde, 1976; 54: $148-153$.

G1e1, R. \& G.H.H.M. ten Horm: De verhouding tussen hulp-vraag en -aanbod: risicogroepen in de GGZ. TIjdschrlet voor Psychiatrie, $1981 ; 23: 504-521$.

Goldberg, D. \& P. Huxley: Mental illness in the community. London, 1981.

Hamers, H.J.F.R. G.A.M. Driessen: De geestelijke gezondheidszorg en har risikogroepen. Tijdschrift voor Sociale Gezondheidszorg, 1986; 64, nr. 17: 562-567.

Hamers, H.J.T.R. F.G. Brook: De GGZorg in het noorden en zuiden des land in 1981. I1Jdschrift voor Psychiatrie, 1986; 28: 254-266.

Hamers, H.J.F.R. De soclale en ruimtelijke spreiding van pisychlatrische morbiditeit. Te verschljnen (1987).

Norubia, M.J.: SPSS-X Advanced Statistics Gulde. New York, 1985.

Koot, $\mathbf{T}$. Stegerhoek: Zorgzame samenleving. Tussen recht en ruil. Harmonisatieraad welgijnsbeleid, Den Haag, 1986.

Verdonk, A.: Stadsbuurten, de ene is de andere niet. Deventer, 1979. 


\subsection{Samenvatting}

In hoofdstuk 7 stond de vraag centraal of en in hoeverre onze reglonale GGZ vergelijkbaar is met en andere regionale GGz, met als achtergrond de nog niet beantwoorde vrag in hoeverre te generallseren uitspraken omtrent de nederlandse GGZ veroorloofd $z i j n$. In hoofdstuk 8 waren wij erop gespitst te achterhalen hoe de GGz als organisatle functioneert.

In hoofdstuk 9 had ik meer dan in de twee voorafgande hoofdstukken oog voor de GGZ-consument. Om de kans met de GGZ in contact te komen voor alle leden van de onderzoekspopulatie gelijk te doen zijn (ten gevolge van de afstand tot de GGZ), heb Ik mif in dit hoofdstuk beperkt tot de inwoners van de stad Mastricht. Van deze populatie is over een viertal jaren het incidentiecijfer voor de GGz per jaar berekend; deze 'incidentiepopulatie' bestaand ult bljna 6500 individuen vormde in dit hoofdstuk mijn feitelljke onderzoekgroep.

De bevindingen kunnen kort als volgt gememoreerd worden. In de eerste plaats kon geconstateerd worden, dat er leder jaar per buurt ongeveer evenveel patiénten bij de GGZ verschenen en dat er wat dit getal (per 1000 inwoners) betreft grote verschilien anwezig waren tussen de buurten.

In de tweede plaats konden eerdere bevindingen, betrekking hebbend op 'kans op GGZ' en een indeling met behulp van demografische variabelen, gerepliceerd worden: zo bleken gescheidenen en ouderen een grotere kans te hebben met de GGZ in contact te geraken dan anderen.

Vervolgens heb $1 k$ enkele gestandaardiseerde morbiditeitsratio's (SMR's) per buurt berekend; de hoogte daarvan wordt niet belnvloed door een specifleke opbouw van en buurtpopulatie (naar leeftifd en burgerlifke stat). Deze aldus ontstane ratio geeft een goed vergelfjkingsgetal voor de buurten onderling; het bleek overigens dat voor buurten met lage, gemiddelde en hoge ratio's telkens dezelfde categoriesn (zoals gescheidenen en ouderen) in de desbetreffende buurt de grootste kans hadden met de GGZ in anraking te komen. Overigens zij eraan herinnerd dat het incidentiecijfer (en de darblj) behorende SMR) op drie wifzen vastgesteld werd: het eerste was een algemen incldentiecijfer dat betrekking had op alle GGZ-voorzieningen, het tweede had betrekking op de semi- an do intramurale GGZ en ten slotte het derde dat in felte alle eerste psychiatrische opnamen omvat.

In dit hoofdstuk werd vastgesteld dat de socialo en ruimtelijke spreiding van de angemelde psychiatrische morbiditeit verre van toevallig over de populatie van een stad van ruim 100.000 inwoners verdeeld is. Bovendien blifkt deze niet-toevalifge spreiding stablel gedurende de periode 1982-1985.

Tenslotte is getoond dat het patroon wat betreft angemelle psychlsche problemen een grote overeenkomst heeft met patronen welke ontstaan met behulp van andere indicatoren, zoals die met betrekking 
tot het onderwifs, de antallen witkeringsgerechtigden, e.d..

Derme zif vastgesteld, dat de hypothesen die in hoofdstuk 5 opgesteld werden, miet verworpen kunnen worden.

Wat de GGZ betreft heb voorlopig geconcludeerd dat deze -althans voor de stad Mastricht- har matschappelijke taak "samengestelde gelijkheid bewerkstelligen' $11 j k t$ war te maken; wel 1 a op dit punt twijfel anwezig war het de soort zorg betreft, daar het erop lijkt dat de subpopulaties die het meest geplaagd worden door een slechte goestelifke gezondheld nar verhouding minder extramurale en meer Intramurale zorg ontvangen.

Toch blifft voorzlchtigheld op zijn plats en vel vanwege drie redenen. In de eerste plats zij erop gewezen, dat hier gewerkt is met geagregeerde data, en hoewel geen rechtstreekse relaties op een lager aggregatienlveau afgeleid werden dient men hier voorzichtig te zIjn: uiteindelijk dienen de data verbonden te worden met individuele data (b.v. In de vorm van een contextuele analyse) alvorens men op dit punt definitlevere uitspraken wil doen.

In de tweede plaats is de invloed van de huisarts niet nagegaan; komen er vanuit comige buurten meer patienten naar de GGZ, ondat een hulserts met een hoog detectlevermogen voor psychlache stoornissen zifn practijk daar gelocaliseerd heeft? Dit soort vragen zijn in princlpe te beantwoorden, indien de practijken van de hulsartsen wat betreft enkele simpele (demografische) data doorgelicht zouden kunnen worden.

In de derde plats: in dit hoofdstuk werd gesproken over Incidentiegevallen. Echter, de GGZ kan wat betreft haar matschappelijke taak pas volledig beoordeeld worden, indien ook naar de (aangeboden) zorg gekeken wordt. Daarbij gaat de interesse uit naat de geboden GGZorg zoals dil in de patientcarrieres tot uitdrukking komt. 


\section{SLOTBESCHOUWING}

\subsection{Inleiding}

"De GGZ in wankel evenwicht": het idee van deze titel werd geboren n.a.v. de voorgenomen afbouw van de RIAGG in de door mij onderzochte regio ten gevolge van de normering zoals die door het C.O.T.G. enkele jaren terug werd opgesteld. Immers, deze afbouw bedreigde (en bedreigt) niet alleen de RIAGG, maar brengt veranderingen teweeg in het gehele zorgsysteem.

Echter, de titel is op meer manieren te lezen. In de eerste plats is getoond dat het ontstaan van de GGZ moeizaam ging, waarbif met name de uitbouw van diverse extra- en semimurale zorgvormen lang op zich lieten wachten en ten dele nog op zich laten wachten. Ook, in de tweede plaats, bleek nogal eens dat een zorgvorm bedoeld voor een categorie patilnten daarvoor fuist niet geschikt bleek, terwijl andere -nog niet ontdekte doelgroepen-daarvoor wel gevoelig waren. ook daarin bleek en blijkt de GGZ als een zorgsysteem dat zich vanuit het ene 'wankele' evenwicht naar een ander -even zeer 'wankel'ontwikkelt.

Ten slotte, blijkt het onderwerp van de GGZ -'gekte'- geen voordeel om als institutie ingang te vinden: jufst dit onderwerp levert vanwege zijn matschappelijke geladenheid niet het crediet op dat de GGZ wellicht wel verdient. Dit wordt nog eens versterkt doordat de GGZ zich tracht te legitimeren door te wijzen op haar medische achtergrond, terwij1 dit echter niet de enige is. De relatieve buitenstaander zal met recht op deze dubbelzinnigheid wijzen: diens oordeel over de GGZ kan hierdoor negatief beinvloedt worden.

In dit hoofdstuk zal ik enkele conclusies naar aanleiding van de hier gepresenteerde deelstudies trekken. Na een korte inleiding worden deze conclusies weergegeven warbij een verbinding wordt gelegd tussen de theoretische beschrifving van de GGZ als cultureel en als soclaal systeem en de empirische bevindingen. Dok wordt aangegeven op welke punten nader onderzok gewenst is. Ten slotte wil ik niet nalaten enkele speculaties over de toekomst van de GGZ an te dragen.

In het empirisch deel van deze studie is in de eerste plats getoond, dat de GGZ in een regio veel lijkt op die in een andere, warbij voorzichtig geconcludeerd werd, dat in grote lijn de regionale variatie qua GGZ-structuur niet zo groot is als op andere gronden vaak verondersteld wordt. Toch moet eraan herinnerd worden, dat er in hoofdstuk 7 de nodige verschillen tussen twee regionale GGZ-systemen geconstateerd werden. De belangrijkste hadden van doen met de onvang van met name de semi- en de extramurale GGZ in het zuiden: deze bleek immers op die punten groter. Ook bleek het mogelijk dat een functie door verschillende GGZ-voorzieningen ingevuld wordt. Voorlopig kan 
uit de bevindingen geconcludeerd worden dat het landelijk beleid niet te zeer in detail kan platio vinden zonder dat dit ten dele onvoorzlenbare, problemen in deze of gene regionale GGz tot gevolg zal hebben. Anders gesteld, an een reglonale GGZ -als gezamenlifk bijeen In de RIGG- kan een belangrijke tak wat betreft monitoring, evaluatle en planning toegedacht worden.

Dat deze toebedeling richting regionale GGz geen luchtspiegeling behoeft te zifn, bleek ult de bevindingen van hoofdstuk 8 , waar Beconcludeerd werd dat de functionele samenhang en differentiatie in de reglonale GGZ in de tijd blijkt toe te nemen.

Ten slotte bleek (in hoofdstuk 9), dat de gerealiseerde behoefte an GGZ verre van toevallig over de populatie verdeeld is; daarbij bleek behoefte an GGZ samen te gaan met problemen in andere domeinen die lets leren over de qualiteit van het bestan. De vragen die op dit punt nu onbeantwoord blijven, komen voort uit methodologische beperkingen (samenhangend met het agregatieniveau van de data en de invloed van de eerste 1 ijn) of hebben van doen met inhoudelijke items (zoals de ard on de qualitelt van de geboden zorg).

\subsection{De huldige GGZ}

In de eerste plats kan gememoreerd worden dat in Nederland slechts een minderheld van diegenen die wat betreft hun geestelijke gezondheid onvoldoende scoren, ook bij de GGZ in behandeling is. Echter, ook wat betreft lichamelijke klachten -zeker als zij niet een onmiddeliljk en duldelifk gevaar in zlch meedragen- zal er vaak geen sprake zifn van een zoeken van specialistische behandeling. Bovendien zij erop gewezen dat het antal personen bij de huidige GGZ in behandeling hoog is in vergelijking tot het verleden en tot in de ons omringende landen.

In de tweede plaats zij er op gewezen, dat het merendeel van de GGZ zich ambulant afspeelt; d.w.z. dat de meeste patienten die in contact net de GGZ komen en ambulante behandeling ontvangen.

In de derde plaats, blifkt het mogelijk de regionale GGz te bezien a cen organisatie "warin gandeweg de onderdelen meer op elkaar worden afgestemd: m. a. wet $11 \mathrm{jkt}$ mogelifk de regionale GGz als een social-subsystem te beschrijven, warin planmatig te werk gegaan wordt, wardoor ook in de GGZ min of meer gewerkt wordt volgens de principes van het instrumenteel rationalisme. Onderzoek kon en kan dartoe en bijdrage leveren.

In de vierde plats biljkt niet ledere subpopulatie evenveel gebruik te maken van de $G G Z$; behoefte aan GGZ blijkt samen te hangen met andere factoren. Een regionale GGZ die juist ook die groepen bedient, die de meeste problemen angaande hun geestelijke gezondheid hebben, zal gemakkelijker anspraak kunnen maken maatschappelijk gelegitimeerd te worden. Voor de door mif onderzochte regionele $\mathrm{GGZ}$ lijkt dit tot op zekere hoogte op te gaan.

Tenslotte, is het vanuit de concrete beschrijving op indirecte wifze 
mogelijk de GGz als cultureel-subsysteem te bezlen, warbif enerzljds har matschappelijke legltimatle nar voren komt, em warult anderzifds har moellifke positie als institutle opererend op de grens van het mastschappelijk systeem zichtbaar wordt: immers de GGZ kan wel compenseren, mar ongelifkheld als zodanig niet wegnemen.

\subsubsection{Als cultureel sgsteem}

Het culturele systeem is het geheel aan ideedn warmee wij het menselijk (samen)leven $z$ in geven: daarmee wardt ons sociaal handelen voorgestructureerd en weten wif $g$ lobal welk social handelen wij van onze tegenspelers kunnen verwachten.

Zo kan de GGZ als cultureel-subsysteem bezien worden; met behulp van dit cultureel-subsysteen kunnen ondervonden problemen zoals die in het soclaal handelen tot ufting komen alsnog "getackeld" worden. In die zin past de GGZ in een cultuur warin rationalitelt en het oplossen van problemen voorop staan. Maar ook is daaruit af te leiden dat personen die in het algemeen beter passen in, beter agngepast zijn an het overheersende culturele systeem-vooropgezet dat de GGZ daar een onderdeel van uit makt- ook beter met die denk- en handelwijze in de GGz overweg kunnen: kortom, gevoeliger zijn om bepaalde problemen als een GGZ-probleem te benoemen. Dit zal zeer duidelijk opgaan voor diegenen, die een opleiding hebben genoten die kort tegen de GGZ aanzit, of die anderszins kennis van de GGZ als cultureel-subsysteem hebben.

Algemeen kan aangenomen worden dat deze relatief nleuwe vorm om het leven (en problemen daarin) vorm te geven anvankelijk slechts bif kletne groepen -veelal de hogere en de middenklassen-bekend zal zijn: deze bekendheid zal zich alechts geleidelijk verbreiden onder de populatie. Dat kan onder meer gebeuren door de anwezigheid van GGZ-voorzieningen wardoor de GGZ als cultur een sociale verdichting $\mathrm{krijgt}$.

Toch kan verwacht worden, dat juist diegenen die het meete kans lopen problemen aangaande kun geestelijke gezondheld te krijgen, het minst bekend zijn met technieken zoals die in de GGZ ontwiklkeld zijn. Ondanks deze opmerking lijkt het erop, dat de GGZ zich langzam "lnvecht" in het dagelijks leven van de gehele populatie linclusief diegenen die het verst afstan van de GGZ als geheel an verkiaringsen behandelingsmodellen. Hoe deze constatering gewardeerd dient te worden, hangt af van het te hanteren uitgangspunt vanuit hot standpunt van de GGZ bezien zal deze constatering positief ingeschat worden: vanuit de (toch wel optimistische) ondertoon van deze bundel zal de GGZ-werker de toekomst hoopvoller tegenoet zien dan dat de dagelijkse realiteit daartoe voor her/har veelal anleiding geft. ook vanuit een standpunt marin rationaliteit, planmatigheid, e.d. voorop staan zal de constatering dat het instrumenteel rationalisme ook "zegeviert" in een schemergebied van het menselijk bestan-gekte geheten- positief gewardeerd worden. 
Echter or is een tegendraads atandpunt in te nemen, vam warult tot een negatieve beoordeling wordt gekomen en van varuit een pessiwistische visile op de Bamenleving blijkt. Hiertoe kom je vanneer je vanult en cultuurfilosofisch standpunt vaststelt dat een van de latste domeinen van het prive-1even -wellicht dan wiet het mest plezierige deel-veroverd wordt door het instrumenteel rationalisme. De keuzen die ons als individu en als collectief resten, dienen binnen dat instrumentel rationalisme te liggen: de toenemende suprematle van dit cultuurpincipe kan eteeds moellijker ter discussie gesteld worden.

\subsubsection{A1s socianl sgeteen}

Is de theorle een cultureel subsysteem, de practijk van de GGZ is een soclaal aubsysteem. Eenmal ontstaan, beinvloedt deze practijk het culturele syteem en kan door wederzijdse anpassing de inpassing van dit culturele subsysteem in de onvattende cultuur bewerkstellingen.

De GGZ als sociaal systeem kan de context warin zly zich bevindt belnvloeden: een GGZ als (regional) social systeem kan gaandeweg latente behoeften in de populatie manifest maken. Dit kan ten dele geschieden langs het kanaal 'huisarts' *1*. Echter, ook de output van de GGZ zal een zekere qualiteit moeten hebben: de perceptie van de hulsarts, van andere verwijzers en van de (behandelde) populatie zal positief moeten zijn, wil de GGZ als cultuur langs deze weg verspreid worden.

Laten ij ens en gedachtenconstructie opzetten, warin de GGZ -als cultureel systeem- nog in het geheel niet is ingebed in de samenleving. Dan zal slechts een zeer klein deel van de psychiatrische morbiditeit boven water -bij de GGZ- komen: namelifk datgene wat vroeger als 'intramurale morbiditeit' verscheen $B$ if de start van de extramurale GGZ -anders dan die welke rond de intramurale zorg georganigerd is- zal deze nieuwigheid het eerst anslaan bif die klassen die deze vorm van probleemhantering ultgevonden hebben. In de beginfase van de extramurale GGZ zal deze vooral een aantrekkingskracht hebben op de hogere en de midden klassen, terwijl deze vorm van bohandeling voor de lagere socile klassen minder voor de hand $1 \mathrm{dg}$. Een nog niet volledig ontwikkelde GGz met en onvoldoende Inpassing in de samenleving zal een beeld oproepen, warbij juist voor diegenen die het meest latente behoefte an GGz hebben, het minste a anbod anwezig zal zijn en warblj het wel anwezige anbod intramurabl zal zijn.

In hoofdstuk 9 heb ik echter laten zlen, dat in het algemeen er sprake is van een tamelijk gelijk opgaande consumptie van de verschillend zorgsoorten. Hieruit zou een nog mader te toetsen hypothese geformuleerd kunnen worden, die er op neer komt dat de regionale GGZ *2*, die hler onderzocht werd, redelifk is ingepast in de samenleving die zif bedient. Het is in die zin dat de GGz werkaam 
lijkt te zijn als een institutie die een functie heeft om samengestelde gelijkheid te bewerksteligen.

Toch blek ook, dat vanuit buurten (subpopulaties) die positief scoorden wat betreft de gehanteerde indicatoren -wijzend op een "hoge qualiteit van het bestaan'- er naar verhouding nog minder gebruik gemakt werd van de intramurale GGz vanuit negatief ocorende buurten bleek de populatie -hoewel veel van de GGZ gebruikmakend-daarentegen naar verhouding minder gebrulk te maken van de extramurale zorg en meer van de intramurale zorg.

Een definitieve ultspraak betreffende de inbedding van de GGz in mijn onderzoekspopulatie is nog niet te geven nader onderzoek is noodzakelijk naar met mame de soort GGz dif angeboden/geconsumeerd wordt. Daarbij zal de factor tijd moeten worden betrokken: kort en goed, nast het 'in zorg komen' zal ook de patidntcarriere bekeken moeten worden.

Tot slot is het hier van belang te constateren dat julst ondat GGZ-problematiek op geaggregeerd niveau samengat met andere minder prettige zaken het van belang is te blijven zoeken naar de factoren die negatieve gevolgen voor de gezondheidstoestand tot gevolg hebben. Concreet zou dan gekeken moeten worden naar consequenties van allerhand sociale veranderingen, zoals van optredende werkloosheid, stadsvernieuwlingsprocessen, e.d..

\subsubsection{Implicaties voor verder onderzoek}

De constateringen in de vorlge paragraaf, behoeven bepald niet als vaststaand aangenomen worden. In de eerste plats ondat de conclusies op geaggregreerd niveau getrokken zijn; dus een verbinding met data op Individueel niveau ( $0 . a$. In de vorm van contextuele analysen) is zeer gewenst. In de tweede plaats is ook nu al te zien, dat de correlaties weliswar hoog zijn, mar ook dat enkele buurten, negatief scorend wat betreft een antal indicatoren (zoals werkloosheid, antal uitkeringsgerechtigden, etc.) in het geheel niet slecht scoren wat betreft de aangemelde morbiditeit: soms bljjken met name de "ambulante anmeldingen" lag. Hierult mag zeker niet zonder meer beconcludeerd worden, dat de anwezige morbiditelt laag is. Immers het $1 \mathrm{~s}$ ook mogelijk dat de GGZ als cultureel (en dus als sociaal) systeem bif de populaties van die buurten nog geen vaste grond onder de voeten heeft gekregen. Een mogelijke reden kan obo bif een "typische" hulsarts 1 iggen; controle hierop is noodzake $11 \mathrm{Jk}$.

In de derde plaats zal ook de patientcarriere in vervolgonderzoek meegemomen moeten worden.

Verder onderzoek zal dus gericht moeten zijn op de populaties van enkele specifleke buurten en zal o.a. de morbiditeit en de attitude ten anzien van de GGZ op individueel niveau meten. Deze data worden geanalyseerd tegen de achtergrond van de context, de buurt: deze analysen kunnen ons lets leren rond de eerste twee vragen. Daarbij hoort echter ook, dat voor de invloed van de hulsarts gecontroleerd 
wordt; deartoe zijn per huigartopraktijk enkele eenvoudig te verzamelen gegeven nodig (zoals het antal patienten en de verdelingen naar leeftifd, burgerlijke stat en buurt). Wat betreft de derde opmerking kan gemeld worden dat met behulp van de in het regleter opgeslagen data de patientcarriere te reconatrueren is. Het onderzok hiernaar wordt inmiddels ultgevoerd.

Tot lot is het mogelifk - al dan nlet m.b.v. de buurt als ingang-om to zoeken in de populatle nar grote soclale veranderingen en daarvan consequenties vast te atlen. Als voorbeeld: er kan een populatie morden samengesteld van diegenen die collectief ontslagen zijn ten gevolg van inkrimpingen. Daarnast dient een "controle-groep" samengesteld te worden. Vervolgens wordt gedurende een vervolgperiode bekeken welke groepen het meest met (en welke) institutles, bedoeld om amengeatelde gelifkheid te realiseren, in aanraking komen.

\subsection{De toekomst pan de GGZ}

De opkomst en de uitbreiding van de GGZ was mogelijk in een samenleving die in tomemende mate complex wordt" een samenleving die in toenemende mate bestaat dankzij zich steeds verder ontwikkelende afhankelijkheidsrelaties. Daarbij is het mogelijk in steeds toenemende mate complexiteit te reduceren, mar tegelifkertijd neemt ook de behoefte an die reductie toe. Dat is de consequentie van zichzelf versterkende processen, die in het instrumenteel rationallsme hun vertrekpunt vinden. Toenemende arbeidsverdeling en specialisatie gaan dan hand In hand en vormen zo zichzelf autonoom voedende subsystemen, die wellswar afhankelifk van anderen zijn -overheid, financiers en (potentiele) klanten- "mar die ook de anderen in sterke mate weten te belnvioeden. Geldt dit voor verschillende instituties, 0.a. voor de somatische gezondheidszorg, het gat ook op voor de GGz.

In hoofdstuk 4 -met name in de afsluitende concluderende opmerkingenbespreek $1 k$ met optimisme de toekomst van de GGZ. Aan het eind van deze studie ben ik van mening dat ik de in hoofdstuk 4 geventileerde mening kan handhaven; uiteraard ben 1 k mijervan bewust een globale kijk op de GGZ te hebben gepresenteerd. Daarbij ben ik mij er van bowust dat vele problemen in de hedendagse GGz hier niet genoemd zijn. Dat wil nlet zeggen dat ik die problemen zou willen ontkennen of zou wilen bagatelliseren; wel ben 1 k van mentig dat deze poblemen gandeweg beter hanteerbar gemakt kunnen worden. Daartoe zullen de anzetten tot een reglomallsering van de zorg verder gevoerd moeten worden. Immers het terrein van de GG2 $1 \mathrm{~s}$ zo breed, dat onderlinge aftemming alleen per reglo nauweurlg gepland en getvalueerd kan worden. Dit geldt ook voor het critisch volgen van reeds a anwezige functios. Bovendien is alleen zodoende te bewerkstelligen, dat er per reglo en toegesneden a anbod ontstaat: d.w.z. een a anbod dat past bij de (problematilek in de) populatie die bediend moet worden Dat kan dus ook inhouden dat per reglo -zlj het ufteraard binnen de marges van en totalbudget- voor een andere opbouw van de zorg gekozen kan 
worden. Dit heeft mede als voordeel dat historisch gegroelde situaties niet ontkend behoeven te worden, zoals nogal eens wil geschieden, indien gekozen wordt voor landelijk vast te stellen normen. Een hiermee samenhangend knelpunt dat de (regionale) GGZ momenteel in zijn ontwikkeling remt is het volgende. Als vele zaken gedecentraliseerd worden aangaande planning, e.d., dan lifkt het alleszins redelifk dat belangrijke delen van de financlele verantwoordelijkheden ook gedecentrallseerd worden. Het probleem ontstaat dan echter in de huldige situatie dat regional de budgetten krap gehouden worden, mar dat de Blobale qualiteitselsen waraan de GGZ dient te voldoen, grotendeels landelijk worden geformuleerd. Daarnast kan gesteld worden, dat de verschilien in de wljze van financiering voor de te onderscheiden voorzieningen het tot stand komen van een stablel zorgsysteem niet bevorderen.

In tegenstelling tot het zojulst ultgesproken optimisme is mijn cultuur-critiek pessimistisch van ard. Daarin komt tot uiting dat er voor individuen geen irrationele keuzen meer te maken zifn. ofwel: onze vrijheid is dan relatief groot, over ons materibel welzijn behoeven wij ons ook geen al te extreme zorgen te maken en zelfs aan ons geestelijk welzijn kan gesleuteld vorden, mar wel alles volgens de principes van het instrumenteel rationalisme. Deze tendens blifkt in de $t$ ijd gezien sterker te worden; afhankelijkheid van vele anderen is darbij ons 'lot".

\subsection{Samenvatting en conclusies}

In deze slotbeschouwing is geconcludeerd dat de GGz zeker enige reGionale elgenheid heeft, maar toch ook dat deze verschillen kleiner zijn dan oorspronkelijk verwacht werd. Verder werd vastgeateld dat de Globale rationaliteit in de GGZ toeneemt; plannen, evalueren en bijstellen heeft enerzijds kennelifk zin, maar anderzijds zal daar voorlopig geen einde an komen, omdat een definitief eindprodukt in een zlch veranderende amgeving nooft als een atatisch evenwicht berelkt zal worden. Oak in de GGZ zal de rationalitelt hoogult globaal zijn. De altuatie ook in de toekomst zal als een proces te bezien zijn warbif van het ene 'wankele evenwicht' nat het volgende gegan vordt.

Tenslotte werd gememoreerd dat de GGZ een kennelifke functie heeft in bewerkstelligen van samengestelde gelijkheld en dat 'onze GGZ' deze functie minstens ten dele 1 ijkt war te maken.

Verder leverde deze slotbeschouwing de verwachting op dat de GGZ als cultureel systeem zich verder zal verbreiden over de populatie. Dlt betekent op termifn een uitbreiding van de GGz als soclaal systeem onder de voorwarde dat voor de toenemende vraag naar GGZ een aanbod geschapen zal worden. Echter, gezien de monetaire situatle wordt op de GGZ een zware issel getrokken: dit betekent ook dat er en grote druk op het organisatorisch verrogen komt te $11 \mathrm{ggen}$ or zo efflcient mogelijk gebruik te (blijven) maken van de aanwezlge middelen. 
Een verdere organisatorische ontwikkeling van de regionale GGZ kan voordelen opleveren; noodzakelifk is het dan dat werkelifke decentraliatie doorgewoerd wordt, warbif landelifke criteria en normen nlet bij woorbat al teveel vastleggen. Tenslotte $11 j \mathrm{kt}$ het verstandig on nlet alleen op budgetbasis te financieren, maar ook een link te leggen tussen datgene wat geleverd wordt en de anwezlge rulmte in de budgetten. 
HOOFDSTUK 11

\section{SAKTENVATTING}

Dit boek is opgebouwd uit twee delen. Het eerste bestat uit een vifftal peclaal voor dit boek geschreven hoofdstukken, warin een aantal theoretiache overwegingen gegeven worden, ultmondend in een negental hypothesen: deze worden vervolgens in het tweede deel getoetst.

Deel II is samengesteld uit een negental eerder verachenen (of nog te verschijnen) publicaties; van deze megen zljn er twee onder te brengen onder het hoofdje "methoden en technieken', de overlge zeven bevatten afzonderlifke deelstudies.

In het eerste deel heb ik de volgende onderwerpen an de orde gesteld. Na een inleidend hoofdstuk volgt een beschouving over de wijzen warop 'gekte' bekeken en geoperationaliseerd wordt. Dok enkele verklaringsmodellen en de daaruit naar voren komende behandelingsstrategieûn worden kort besproken. De stelling dat in onze cultuur met behulp van de GGZ de definitie van 'gekte' Is opgeslagen, leidt tot de conclusie dat daarin ook de beperking van de psychiatrische epldemiologle schullt. Daarom heb ik voorgesteld de resultaten van de psychlatrische epidemiologie te herinterpreteren in een macro-optiek: binnen deze optiek zou de plats van de GGZ als sociaal en als cultureel subsysteem in de samenleving bezien moeten worden.

Het derde hoofdstuk is met recht een intermezzo, ondat daar bij het. menselijk handelen in zifn algemeenheld wordt stilgestaan. In dit hoofdstuk wordt op theoretische gronden angegeven hoe belangr $j \mathbf{k}$ het is 'cultuur' als zingevend en voorstructurerend systeen voor dat menselifk handelen bij beschouwingen en bij concreet onderzoek te betrekken. Uit dit hoofdstuk konden een drietal conclusies getrokken worden.

In de eerste plaats bleek dat "gekte' gelinterpreteerd kon worden in termen van (mislukte) sociale handelingen: dit heeft consequentles voor een theoretische onderbouming inzake de relatile tussen het ontstaan van psychische stoornissen en de matschappeiljke positie.

In de tweede plats -en deze notie speelt op macro-nivo- werd geconcludeerd dat onze aamenleving gebouwd is op onderlinge afhankelijkheid en dat dit in combinatie met het heersende principe van instrumenteel rationalisme leidt tot een quasi gelljkheld van de ledem van de populatie. Deze vorm van gelifkheid heb ik - in navolging van anderen- samengestelde gelifkheid genoemd. Aan het tot stand komen van deze samengestelde gelijkheid zal de cGz em bljdrage moeten leveren. De GGZ doet dat door middel van technleken, die in het instrumenteel rationalisme hun achterland hebben. Het begrip instrumenteel rationalisme heb $1 k$ gekozen on te benadrukken dat de relatie tussen de middelen en de te bereiken doelen van belang is en 
dat deze middelen voortiomen ult een positiviatisch gebrienteerde vetenschapsbeoefening.

In de derde plate kon ik beargumenteren dat wij het steeds alnder accepteren als lets in het leven mis gat; wij wensen mislukkingen op theffen, te compenseren, en zodanlge vorm te geven dat de "pijn" verdwijnt. Bovendien blljken daar in toenemende mate technleken voor anwezig. Dlegenen dle vertrouwd zijn met deze technieken zullen deze In toenemende mate toegepast 111 en zien.

Het vierde hoofdstuk behandelt de GGZ als matschappelijk fenomeen. Julst omdat de GGZ getoond wordt als onze manier om met 'gekte' om te gaan, was het noodzakelijk kort an te geven hoe men daar in vroeger tijden mee omging. Ook het ontstaan van de GGZ als soclale verdichting vard geachetst. Daarbij bleek dat het particulier initiatief in een verzulide samenleving de in tijd zichtbaar wordende expansie van de GGZ in de vorm van nleuwe voorzieningen mogelifk makte. Het resultaat was een uitbreiding van met name het objekt van de GGZ 'Bekte'. Het beleid van de overheid als een 'achteraf beleid' kwam im dit hoofdatuk eveneens an de orde.

Tenslotte werden met behulp van een antal afsiuttende conclusies de lifnen in dit hoofdstuk verbonden met enkele eerder geformuleerde ldeeän over het menselifk handelen. Toen kon de GGZ beschreven worden als een verspreider vam het instrumenteel reationalisme in een schemergebied van het menselijk bestaan, 'gekte' geheten. De GGZ maakt het moge11jk -voorheen ongrijpbare-delen van het mensel1jk handelen in een beheersbare vorm te gieten. Bovendien blijkt de GGZ een van de instituties die er voor zorg dragen dat samengestelde gelifkheid tot stand komt. Hoewel ik -ondanks enkele zwakke kantenoptimistisch gestend ben over de algemene toekonstige ontwikkeling van de GGZ, heb $1 k$ vanult een cultuurfilosofisch standpunt een pessimistische visie geformuleerd. Immers klezen voor een leefwijze buiten het instrumenteel-rationalisme is in steads sterkere mate onmogelijk, met als consequentie een steeds verder doordringen van het publieke im het prive-bestaan.

Hoofdstuk 5 vormt een brug tussen het eerste en tweede deel van deze bunde1; In dit hoofdatuk worden vanult de theoretische overwegingen negen hypothesen geformuleerd, die in het tweede deel getoetst worden.

Het erste hoofdstuk in deel II bevat enkele besprekingen van het gebrulkte onderzoeksinstrument. Zowel de achtergrond van en de wensen rond de opzet van het MHCR (een paychiatrisch gevals-reglster voor de reglo zuldelijk zuid-Llmburg), de opzet zelf alsook de mogelijkheden van een dergelijk instrument werden in dit hoofdstuk 6 besproken.

De hoofdstukken 7,8 en 9 bevatten -1 de vorm van een zevental afzonder11jke deelstudies- de resultaten warmee de hypothesen als in hoofdstuk 5 geformuleerd, getoetst konden worden. Hoofdstuk 7 geeft de resultaten van enkele vergelifkingen, warbif de GGZ in twee verachllende reglo"s bezlen wordt. Het blifkt dat de omvang van het 
hulpaanbod de bevindingen kleurt. Zo blijkt er in en reglo meer patienten in behandeling (te komen) dan in de andere; dit geldt vooral voor de extramurale GGz. Ook blljkt dat dergelijke voorzleningen in de twee regio's verschillende functies in het GGZveld vervulien. Tenslotte blijkt in dit hoofdstuk dat in beide reglo's dezelfde categoriežn (naar leeftijd en burgerifjke stat) over- danwel ondervertegenwoordigd zijn in de patientenpopulatie. In hoofdstuk 8 komen enkele vraagstellingen, wasin de reglonale GGZ als organlsatie centraal staat, aan de orde. In de eerste plats blijkt dat het gebrulk van meer GGz-voorzieningen omvangrijk ls : echter dit zogenaamde dubbelgebruik is zeker wat betreft de meer gespecif lceerde GGZ-voorzieningen gedekt door samenwerkingsverbanden tussen die GGZvoorzleningen. In de tweede plaats blifkt de tabelafbakening tussen APZ en PAAZ ten anzien van kortdurende opnamen duidelifk aan te geven met behulp van patient-en (eerdere) zorgkenmerken. Hoofdstuk 9 resultaten toont die lets leren over de behoefte an GGz vanult de populatie (en verschilien tussen verschillende subpopulaties) en over de relatie daarvan met samengestelde gelijkheld. Het $11 j \mathrm{kt}$ erop dat de GGZ -voor de stad Maastricht althans- har taak, julit de groepen berefken met de meeste problemen angande de geestelijke gezondheidstoestand, warmakt. Om definitieve uitspraken op dit punt te doen is echter nader onderzoek vereist.

Hoofdstuk 10 -slotbeschouwing- start met een puntgewifze samenvatting, waruit blifkt dat de eerder geformuleerde hypothesen ten dele Behandhasd kunnen worden. In grote lijnen kan geconcludeerd worden dat 1). de GGZ in een regio oppervlakkig bezien sterk op die in een andere gelijkt, d.w.z. dat de reglonale varlatie niet zo groot is als op andere gronden vaak verondersteld wordt; 2) de onderlinge samenhang en takafbakening in de regionale GGZ in de tijd blifkt toe te nemen en 3) de gerealiseerde behoefte aan GGZ verre van toeval1ig over de populatie verdeeld is en met andere factoren blifkt samen te hangen.

Tenslotte werd in de slotbeschouwing de verwachting uitgesproken dat de GGZ als cultureel systeem -als een set an verklaringsschema's om problemen tifdens het social handelen op te vangen-zich verder over de populatie zal uitbreiden. Dit zal een zware druk leggen op de GGZ als sociaal systeem, wardoor een zware wissel getrokken wordt op het organisatorisch vermogen zo efficist mogelijk gebruik te (b1ljven) maken van de anwezige middelen. Daarbij zal men in toenemende mate aangewezen zijn op kortdurende behandelingen die bovendien geschikt moten zifn voor het behandelen van die categoriein die het meest geplaagd rorden door een sechte geestelijke gezondheld (dus o.a. Individuen uit de lagere soclaal-economische klassen en zeker in de nablje toekomst, de oudere populatie). Verder zal de GGZ, als reg10naal voorzieningensysteem, hear elgen ontwikeling, haar resultaten en has inpassing in de populatie die zif bedient critisch dienen te volgen om zodoende tot een, zij het geen universele, dan toch wel globale rationaliteit te komen. Alleen dan ken zij als institutie 
werkend onder de vlag van het instrumentele rationalisme in onze amenleving gelegltimeerd worden, hoewel dit gezlen het objekt ven de GGZ wel "wankel" zal blijuen. 
This book is set up in two parts. Part I consigts of five ehapters, especially written for this book, in which a number of theoretical propositions are offered that lead to nine hypotheses. These are examined in Part II by means of nime published articles, two on methods and techniques and seven that illustrate apects of (MHCR) Mental Health Case Register research.

In the first part, the following abjects are ralsed: First, a varlety of perspectives of 'madness' are consldered. Explanatory models and the treatment strategles are discussed. The proposition that the labeling of 'madness' Is charged to a cultures mental health care system is discussed and leads to the conclusion that explanatory power of psychlatric epidemiology is 1 imited for this reason. I thus propose a reinterpretation of the results obtained by psychiatric epidemiology and place these results as well as the role of mental health care ithin a social and cultural ausystem of aclety.

The third chapter discusses how important it is to recognize that "culture' is a structuring system for human acts and that these 1 deas should be considered in research. In this chapter three notions are raised. FIrst, "madness" may be interpreted in terms of (unsuccessful) social acts; this has implications for understanding the theoretical relation between the origin of mental disorders and a persons social position. Secondly, it is concluded that our society is bulit on mutual dependence of its members which in combination with the principle of instrumental rationalization leads to a quasiequality of the members of a population, I call this complex equality. The mental health care system can or does contribute to the establishment of this complex equality, by means of techniques based on the instrumental rationalism. Thirdly, the phenomene that we are not capable of accepting the fact that things go wrong in Iife is discussed. We seem to attempt to remove or compensate for fallure, by means of reshaping events in order to make the 'pain' disappear. Techniques for this purpose are in the hands of the mental health care aystem which encourage the $1 \mathrm{r}$ use.

Mental health care as social phenomena is discussed in chapter 4. Slnce mental health care system is "how" we deal vith "madness" in this chapter I discuss brlefly how people dealt wh it in the past and describe the development of mental health care in social terms. Private inftiative in a segregated society system seems to have caused the expansion of mental health care over time "by aupplying new resources. The result was an expansion of concepts of "madness" as the object of the mental health care. That government policles have aften been 'retrospectlve' policies is also discussed.

In conclusion in these chapters the mental health care can be described as a distributor of the instrumental rationalism in a twilight zone of human existence, called "madness". Mental health 
care thus makes it posafble to control formerly intanglble parts of human acts. Furthermore, mental health care seems to be one of the inatitutiong charged wh the realization of complex equality. In general, while I an optimistically disposed towards the future development of mental health care, despite of weaknesses, from a culture-philosophical point of view, I formulate pessimistic viev: it beems to be more and more impossible to choose for a mode of 1 ife outside the instrumental rationalism, and this 111 result in an Increased penetration of public issue into private life.

Chapter 5 connects the first and the second part of this book. In this chapter, nine hypotheses are formulated, IInking the theoretical formulationg wh the research that follows in the second part.

The first chapter in part II contains a number of reviews of the MHCR research instruments. Background detalls and aspects of organizing and developing the paychiatrfc case register for the authern part of South Limbure are discussed in chapter 6 . The chapters 7,8 and 9 contain research results.

Chapter 7, compares mental health care in two different areas, in the north and in the south of Holland. Although the findings suggest some remarkable almllarities, there seem to exist some differences between the mental health care in both areas. Most people contacted outpatient aervicea, especially the so called Reglonal Institutes for Ambulatory Mental Care. In chapter 8 , the mental health care as an organized system is investigated with the MHCR. A great deal of the people who are under the care of the mental health services, can be considered multiple-service-users. This research showed that most of the overlap was covered by a collaboration of services. In fact, it seems that rationality in the field of mental health care as an orgamization is growing. Chapter 9 examines mental health care needs in the population and the difference between separate subpopulations. These are further related to complex equality.

Chapter 10 - final conclusion - starts with polnt by point summing up of the hypotheses, formulated earlier. First, the data suggest that mental health care in different areas is similar, Implying that the regional varlations are not as important as is often supposed. Secondly, the resemblance of the responsibilities taken by different institutions in the reglonal mental health care seems to increase in time. Thirdly, the need for mental health care is unequally distributed over the population, a fact related to a number of soclal and historical factora.

In conclusion, I expect that mental health care, as a cultural system and a ot of explanatory frames to manage problems in social behavior, will expand further into the population. This will put additional pressure on the mental health care 'social' system, requiring wuch from the organizational ability to use available resources. Beslides we will increasingly have to rely on short-term treatment, that are : sultable for the realization of complex equality particularly for the treatment of these categories of 
Individuals most troubled by mental disturbances, such as individuals from lower socio-ecomomic classes and the elderly. Furthermore, mental health care - as a regional service system - wil have to evaluate in a scrupulous way, its own development, its effectiveness and its sultability for the population it serves. Only this way can it be fully legitimated in our soclety as an institution. 
VOETWOTEN

VERANTWOORDING

1. Zle 0.a. de Swaan (1984), warin het nut van protoprofesslonalisering als volgt omschreven wordt: "Mar tezelfdertifd doen zich in de samenleving allerhande conflicten voor, warin de betrokken partijen steun zoeken blj deskundigen om hun tegenstelingen te besiechten. Een dergelijke herformulering van hun geschll in technlsch-wetenschappelifke termen veronderstelt al een zekere mate van bekendheld met de baslsbegrippen en grondhoudingen van de professie die de oplossing moet bleden: veronderstelt dus een zekere mate van "protoprofessionalisering'." (de. Swaan, 1984, p. 216) Onder professiona1 sering kan dan verstaan worden, "het doordringen op alle terreinen van de matschappij van rationel, wetenschappelijk denken en de toepassing van ingewikkelde, theoretisch gefundeerde methode en technieken". (Mok, 1973, p. 71)

2. Bernsdorf (1972) geeft de volgende definitie: "die jeweils kulturell geltenden, einen Sinnzusammenhang bildende, durch sitte und Recht offentlich garantierte Ordnungsgestalt, in der sich das Zusammenleben von Menschen darbietet." (1bid, p. 371)

3. Koot \& Stegerhoek (1986) merken hierover het volgende op: "De Amerikaanse filosoof Walzer heeft voor het vraagstuk van de verdeling van sociale goederen het begrip complex equality (samengestelde gelijkheid) geintroduceerd. Geen enkel soclaal goed is dan zo dominant, dat de verdeling binnen dat goed bepaalt hoe de verdeling bij andere sociale goederen uitpakt." (1bid, p.54)

B.v. niet alleen het inkomen bepalt in Nederland of je een redelijk dak boven je hoofd hebt: allerhand aanvullende subsidies bieden op dit punt soelaas. Zo ook bij een slechte gezondheldstoestand zijn er -ongeacht het inkomen- mogelijkheden voor zorg.

Hoofdstuk 1. Inleiding

1. Het bifzondere an dit soort instituties $1 . t$ " $t$ "blfvoorbeld "het huwelijk, is dat $z i j \mathrm{zich}$ a.h.w. (ook ruimtelijk) verzelfstandigen, wardoor zij een dynamische factor vormen, een verander Ing veroorzakend karakter hebben.

2. Uiteraard mag niet gesteld worden dat er én cultur is b.v. voor alle nederlanders op dit moment; binnen deze algemene verzamelterm zijn de nodige variaties a nwezig. D.w.z. het is niet denkbaar dat er 6en algemene voor ledereen geldende definitle, omschrijuing bestaat voor wat hij/zij als psychische stoornis ziet.

Hoofdstuk 2. Pagchopathologie en verklaringsmodelien

1. Hier is de anti-psychiatrie opgenomen onder het hoofdje "soctalle psychiatrie' omdat immers bij uitstek hier sprake is ven een soclale 
optlek t.a.v. paychische stoornisgen. Sprekend over Sasz en Laing -die weliswar op enkele punten verschillen- zegt Busfield (1986, p.90): It $1 \mathrm{~s}$ society and soclal groups such as the family that have their deflciencies and pathologies, not the findividual."

2. Bovendien vordt er al vroeg een relatie gelegd tussen het voorkomen van deviante gedragingen (en de mate van verspreiding daarvan) en andere macro-kenmerkem van de samenleving, zoals de mate van anomie in de betreffende samenleving.

3. Overigens, de ecologie als methode is in zijn toepassing zeker niet allen gereserveerd voor een toepasing gericht op de spreiding van psychische stoornfssen; ook de spreiding van andere vormen van devlant gedrag en zlekten ken object van onderzoek zijn. Ook behoeft de aggregatie-unit niet een buurt te zijn, mar hiervoor kunnen kleinere en ook grotere gebieden gekozen worden; b.v. de gemeente in het onderzoek van Drop (1979) en landen (zie 0.a. Hank1ss, 1982 en Milbrath, 1978).

4. Daarbif moet bedacht worden, dat vele data op individueel miveau niet of niet betroumbar te verzamelen zijn. Bovendien -als de data in princlpe al wel te verzamelen zouden zijn- zijn vaak de kosten te hoog de gegevens op individueel niveau te verzamelen. Tenslotte moet bedacht worden, dat vele gegevens valk voor andere doeleinden reeds verzameld en anwezig zijm.

5. De kern van de 'ecological fallacy' is, dat de conclusies getrokken op een hoger niveau ten onrechte naar een lager niveau vertaald worden. Dit kan geschieden ondat het model warin de relaties gespecificeerd zifn wel op het geaggregreerde niveau van toepassing 1s, mar niet op het individuele niveau (men spreekt dan van 'specificatie-blas'). Of -en dan is er sprake van 'aggregation-bias'de geagregreerde units zijn zodanig gevornd dat daarin de verklaring voor de bevindingen gezocht moeten worden. (zile o.a. Morgenstern, 1982 en Langbein (Lichtman, 1978).

6. Waar naar mijn idee bij het opstellen van de verklaringsschema's te weinig rekening werd gehouden, is de mogelijkheild van het optreden van circulaire causalitelt. Dit ldee werd door Rome e. . (1981) in schema vergegeven voor wat betreft de relatie tussen sociale klassen en gestelifke gezondheld. Dit model (Ibid, p.43) is ook bruikbaar om relaties tussen andere variabelen in te vullen. In dit model is het mogelifk dat oorzak en gevolg telkens van plaats rullen, warbij achteraf nlet meer vastgesteld kan worden, welke factor als eerste het proces gestart heeft. Bovendien is het denkbaar dat verschillende factoren eenzelfde (clrculalr) proces op gang brengen.

Overlgens, het $11 \mathrm{jkt}$ er sterk op dat de sociale wetenschappen strak vasthouden an een (verouderd?) causaliteitsprincipe dat in wezen gestoeld is op een wetenschapstraditie welke op het werk van Newton 1. gebaseerd. Terwijl met name in de natuurwetenschappen men deze traditie -zeker om complexe vragstukken te benaderen- ingerulld heeft voor nleuwere opvattingen. (zle voor en bespreking van deze nleuwe opvattingen en de consequentles daarvan voor de sociale 
wetenschappen een recent artikel van Bamme, 1987). Daarbif la niet gezegd dat 'Newton" nlet voldoet, maar dat Newton' voor bepaalde vragen nlet deugt. Deze 'creatleve vrijheld durven de soclale wetenschappen kenne11Jk nog nlet an.

7. Interessant is de bevinding dat locus of control enerzijds samenhangt met sociale klasse, opleiding, e.d. en anderzifds met geestelifke gezondheid gemeten als persoonlijkheldakenmerk (b.v. neuroticisme-score) en als de feltelijke geestelljke gezondheld op dat tijdatip. Lagere sociale klasse hangt samen met en externe locus of control, terwijl een externe locus of control samengat met een slechtere geestelffke gezondheld.

B. De studie naar culturgebonden syndromen is hler van belang: $a 10$ b.v. voor een recent artikel Prince Taheng-Laroche (1987) en de moeilifkheid dit soort gyndromen onder te brengen in een diagnostisch systeem als b.v. de DSM III.

Daarnast blijkt uit vele atudies de invloed van cultuur, van culturele verschillen, op de wijze warop kinderen gesoclalisere worden, welke persoonlijkheidskenmerken in welke richting angescherpt porden.

9. Een uitzondering hierop vormt het verslag van een antal case-studies over patiknten in Harare. In deze beschrijuligen stat de relatie tussen een specifieke cultuur en het ontstaan/becindigen van de stoornis (Romne, 1987) centraal: met name is er aandacht hoe om binnen een netwerk al dan niet met positieve gevolgen met stress wordt omgegaan.

Hoofdatuk 3. Intermezzo: het menselifk handelen

1. In feite bevind ik mij in de traditie van het noo-kantiaans denken gemodificeerd door een cultureel relativisme zoals dat in het werk van Boas (1962) en Benedict (1960) naar voren komt (zie ook Hymes, 1974).

2. Cultur is uiteraard meer dan warden en normen. Ook de ethiek, de moraal. de kunst, de semiotiek -om nar enkele termen to noemen zonder volledig $z 1 j n$, zonder an te nemen dat alle termen van eenzelfde orde zijn er er geen overlappingen zouden zija- behoren tot de cultuir.

Bernsdorf (1972, p.479) zegt: "Kultur 1st die Gesantheit der typlschen Lebensformen lner Bevolkerung, elnschliessilch der sie tragenden Geistesverfassung, Insbesondere der Wert-Elnstellungen." en "Dle 'typigchen Lebensformen' Imfassen auch die technischen Grundlagen des Deseins samt ihren materielien substraten (Kleldung, Obdach, Werkzeugen und Gergten, usw.) und dem gestalteten Naturraum als 'Kulturlandschaft'."

3. Weber heeft het aldus geformuleerd: "Es ist in kelner Art gesagt: dass die an dem aufeinander ingesteliten Handeln Beteiligten im Einzelfall den gleichen sinngehalt in die soziale Beziehung legen oder sch sinnhaft entsprechend der Elnstellung des Gegenpartners 
Innerich zu thr einstellen, dass also in diesem Sinn 'Gegenseitigkeit" besteht. 'Freundschaft", "Llebe' "Pietdt', 'Vertragstreue'" 'nationales Gemelnschaftsgefuhl' von der elnen Selte kann auf durchaus andersartige Elnstellungen der anderen seite stossen. Dann verbinden eben dle Betelligten mit Ihrem Handelm einen verschiedenen Sinn; die goziale Beziehung lot insowelt von belden Selten objektiv "elnseltig'." (Weber,1972, p.13)

4. De hler geformuleerde opvatting ten anzien van het sociale handelen heef betrekling op gedrag gericht op een individu; gedrag met betrekking tot dieren, mar ook culturrelementen in zijn algemenheid, $11 \mathrm{Jkt}$ darmee ultgesloten, mar is het nlet gehel en a1. Imners bekijken wij mijn gedrag tegenover de tekstverwerker -al schrijvend onder mijn handen- dan moet bedacht rorden dat niet het oppervlakkige gedrag -het tikken- van beleng is, mar dat die tekstverwerker het product is van een lang proces van menselljke handelingen en warblj zowel de tekstverwerkers alsook het ulteindel1jk manuscript een (half)produkt van sociad handelen $z i j n$.

5. De oplnie die hler wordt weergegeven is oterk interactionistisch bepald. Toch moet bedacht worden, dat b.v. indien ik mijn bureau tracht te klleven -en er dus oppervlakkig gesproken is van gedrag en niet van sociaal handelen- de "soclologische observator" niet geimteresseerd is in dit klieven sec, maar in het proces van elkar opeenvolgende (soclale) handelingen, wardoor weer duidelifk wordt dat dit klieven gezien kan worden als het optreden van incompatibele angevingen verband houdend met een soclale relatie.

Deze opinie is niet 'oorzakelifk" bedoeld: m.a.w. de incompatibilitelt -de tegensteling tussen do attitudesystemen- kan toegeschreven worden $0 . a$. aan geheel bulten het individu en buiten de soclale relatie/het social handelen liggen. B.v. ruimtelijke omstandigheden, van 'buitenaf' optredende factoren, etc. kunnen veranderingen in het individu 'veroorzaken' en zo leiden tot incompatibele zingevingen.

6. Immers het sociale systeem als totalitelt wordt opgebouwd uit telkens kleinere gybsstemen, warbij het kleinste element -het soclaal handelen, het interactiesysteem- als bouwsteen dient. Sociale syatemen bestaan madrukkelijk niet uit personen, mar uit de handelingen van die personen. (Luhmann, Soziologische Aufklyrung I Aufsutze zur Theorle sozlaler Systeme, Opladen, 1970. p.67 en 68). Het ls juist in die in -vanwege de afhankelijkheid van het grotere sociale system vam de prestaties binnen de interactiesystemen- dat Ik de bedreigling "In principe' noem. Viteraard moeten binnen een groot deel van de interactiesystemen lets scheef gaan, wil deze bedrelgling concreet worden en om die reden is de bedreiging nlet snel realiteit.

7. Met name liet Ellas zien hoe de gedragsstandaarden vanaf het efnde van de middeleeuwen tot an het begin van de negentiende eeuw veranderden en dat die veranderingen telkens starten in de bovenlaag en geleidelijk narar de lagere klassen 'druppelen'. Deze veranderingen 
worden door Ellas toegeschreven an de toenemende voclale vervlechting en de staatsvorming. Het typerende a an de goschiedenis in (West) Europa is dat in een korte tijd van 300 a 400 jaar zo'n grote sociale, politleke en technischeveranderingen plaatsvinden, terwil 1 ook de moderne staat in deze periode tot stand kont en de omgangsvormen tussen de mensen drastisch veranderen.

8. Het begrip 'instrumenteel rationalisme' heb ik hler om verachillende redenen gekozen. Het begrip is naw gelieerd an Vebers 'zweckrationalitat', m.a.w. de relatie tussen het te berelken doel en de gekozen middelen -de weg warlangs het doel met zo min mogelijk kosten berelkt zal worden- Ia van groot belang. De toevoeging "Instrumenteel" is essentleel en vol vanwege drie overweglngen. In de eerste plats om an te geven dat rationalisme hler als "zweckrationalitut" bedoeld wordt en dus de relatie tussen doel en middelen van belang is. In de tweede plats de benadrukking dat de doelen bereikt worden met instrumenten (in de meest brede $z 1 n$ ) die hun achtergrond hebben in de (positivistische) wetenschapsbeoefening. In de derde plaats -nauw verbonden met de eerste twee overwegingen- blijkt hieruit het proceskarakter van het hier bedoelde rationalisme: er is een begintoestand van het te bewerken materiaal, van daaruft wordt een probleem gesignaleerd, een vraagstelling geformuleerd, deze mondt ut in een doelstelling, daarbif worden de relevant geacht middelen gekozen en tenslotte worden deze ingezet teneinde van een begintoestand nar eindtoestand te geraken. Uiteraard behoort bif dit alles een evaluatie in termen van doelbereiking en de al dan niet julste keuze van de middelen. Het formuleren van de doelen als zodanig kort kennelijk niet tot stand op basis van een 'rationele' discussie.

9. De eerste twee bewegingen $11 j k e n$ inderdaad tegenstrijalg, maar julst de derde beweging ondervangt de paradox. Eigenlijk kan je stellen, dat de uitstoting niet zo dramatisch als vroeger platesindt (warbil) het individu in zijn totaliteit uitgestoten werd), maar dat slechts een deel van het individu (betrekking hebbend op soms een zeer beperkt antal interactiesystemen) uitgesloten wordt en zo de mens niet in zijn totaliteit tot ongeving wordt gemakt. Deze beperkte uitstoting krljgt vorm binnen specifleke voorzieningen: in die.zin is er sprake van een (partiele) uitstoting door inslulting (binnen specifieke voorzieningen). Het aantal personen dat bij zo'n (partiele) uitstoting betrokken is, is echter anzieniljk in vergelijking tot vroeger.

10. D. $z$. gemakshalve ga ik er telkens vanuit dat dit social handelen tussen twee individuen betreft: er kan uiteraard sprake zijn van een veelvoud wat betreft het antal betrokkenen.

Hoofdstuk 4. De geestelijke gezondheldszorg als matachappelijk fenomeen.

1. Het de onderzoekspraktijk $11 \mathrm{jkt}$ ook lets an de hand te zljn (Beekers, 1986). Uiteraard wens $1 k$ mif als "bultenstaander" niet in 
deze atrijd te mengen die volgens somigen (zie Smith o.a.,1980) als vitrlool nogal ens in de literatur van het effectonderzoek maar voren komt.

2. Howel dit gezlen de beperkte middelen en de daartoe benodigde energie (ook voor de patient) nog maar zeer velnig schljnt voor te komen.

3. Hoewel er grote twiffels zifn omtrent hoe dit geoperationaliseerd moet vorden.

4. Ondere hogere klasse bedoel dus niet de 500 van Mertens of lets ven dien ard: $1 \mathrm{k}$ bedoel diegenen die volgens de ITS-beroepen Indeling op de hoogste schaal terecht komen, en alhoewel ook deze operationalisatle beperklmgen oplevert, wordt zo het ldee nog het beste benaderd.

5. Vooral dient bedacht te worden dat de leefomstandigheden sterk verbeterd zifn 0.a. door de anwezigheld van de sociale zekerheid; de confrontatie met onplezierige gebeurtenissen wordt door $0 . a$. medicatie beter hanteerbaar. Bovendien kunnen een aantal vormen in een vroeber stadiun redelijk effectief behandeld worden d.m.v. psychotheraple.

Dok de groep chronici is zeker niet in zijn totaliteit hetzelfde gebleven: dit en door matschappelljk veranderingen (nu meer opnamen t.B.v. misbrulk van middelen -vooral alcohol-en t.g.v. veroudering van de populatie) on door therapeutische mogelijkheden (b.v. de belnvloeding van de 'expressed emotions' in het gezin, wardoor de afhankelifkheid van -intramurale-zorg in de tijd gezien korter kan zijn).

6. Homosexualiteit kon pas als 'ziektebeeld' uft de GGz verdwifnen, nadat deze afwijkende beleving als een geëmancipeerde variant naast de gebruikelifke geaccepteerd werd.

7. Een ultzondering is de Social Pedagogische Dienst als ambulante zorgvorm voor intellectueel gehandicapten die als welzijnsvoorziening betiteld $1 \mathrm{~s}$ en als zodanig door het Ministerie van WV gefinancierd wordt: deze voorzlening behoort in strikte zin dan ook niet tot de GGZ.

Hoofdatuk 5. Ben brug: van theorie nar emplre.

1. Voor de psychoanalyse als afzonderl1jke professle heeft Bulhof (1983) het proces, tijdens welke de psychoanalyse als 1 dee aan de man gebracht werd, beschreven (dus het ontstan van de psychoanalyse als culturel subsystem in de nederlandise samenleving); Brinkgreve (1984) verhalde voor diezelfde club over de vestigingsstrijd (dus het ontstaan van de psychoanalyse als sociaal subsysteem in de nederlandse samenleving).

2. Hoewe 1 ; dit in een antal landen 0.2 . andat deze dunbevolkte gebleden kennen, noolt op een volledige manler tot stand zal kunnen komen.

3. Misschien moet zelfs gesteld worden, dat julst door middel van socialisatie de nieuwe gedragsvormen echt goed geveatigd worden en wordt civilisatie niet alleen mede door socialisatie als proces 
Bande gehouden, mar worden fasen in dat clvillsatieproces vervolmaakt $t$ ijdens de oclalisatie.

Hoofdatuk 6. Ben paychlatriach case-reglater

1. Sinds 1974 als een gemeentelifk register operationeel, terwij1 nu een groter register voor de gehele provincie Drente opgezet $1 \mathrm{a}$.

2. Dit soort vragen zullen wij beantwoorden in een projekt dat per 1.1.1988 start onder de titel 'Chronische GGz-patronen' dat nu als pilot in uitwoering is.

Hoofdatuk 7. De reglonale GGZ

1. Op dit punt is een klein, mar zeer irritant foutje in de tekst geslopen: hier behoort het woord 'niet' niet te staan.

Hoofdstuk 10. Slotbeachouving

1. Interessant is b.v. het gegeven dat een minderheid van alle hulsartsen een meerderheid van alle GGZ-patienten "toelevert", terwijl nog onduldelijk is of dit ligt aan verschilien in het detectievermogen of in therapeutische vardigheden van de huisarts of an verschillen in morbiditeit tussen de praktijken.

2. In feite alleen de stad Masiticht, voor het ruraal en suburbaan gebied zal dit warschijnlijk in veel mindere mate gelden. 


\section{LITERATUUR}

Aakster, C.W.: Sociologle van de gezondheldszorg. In I. Rademaker (ed), Toegepaste sociologie. Spektrum, Utrecht, 1981.

Abraham, R.B. \& W.B. Gunnimg: De reglonale psychlatrische kliniek en de psychiatrische afdeling van het algemeen zlekenhuls. Medisch Contact, 1976; 31 : 513-520.

Albinskg, $M .:$ Onderzoek en aktie. Over de relatie tussen social wetenschappelijk onderzoeken en menselijk handelen. Assen, 1978.

Anonfem: Editor's Comment (as a reply at Favazza, 1986). Transcultural Psychiatric Research Review, 1986 Vol. XXIII; 1 : 87-89.

Baldwin, J.A.: Linked record medical information systems. Proceedings of the Royal Society of London, serles B., 1973; 184 : $403-420$.

Bamme, A.: Wenn aus Chaos ordnung wird. Die Herausforderung der Sozialwissenschaften durch die Naturwissenschaftler. Klagenfurt, 1987.

BAvo-rapport: Van probleem tot psychiatrie. $3 \mathrm{e}$ rapport visle commissie, 1978 .

Beckers, B.H.C.: Persoonlijke vaardigheldstherapieun voor kansarmen. Lisse, 1986.

Beekers, M.: Interpersoonlijke vaardigheldstherapieün voor kansarmen. Lisse, 1982 .

Beekers, H.: Gemiste kans. Bespreking van S. Schagen e.a." De praktijk van de psychotherapie. De Psycholoog, $1986 \mathrm{jrg}$. XX1; 3 : 127-129.

Beels, C.C. : Social networks and schizophrenia. Psychlatric Quaterly, $1979 ; 51: 209-215$.

Beenackers, A.A.J.M.: Projekt-evaluatie in de geestelijke Bezondheidszorg. Delft, 1986.

Benedict, R.: Patterns of Culture. Mentor, New York, 1960.

Bernsdorf, W.: Worterbuch der Sozlologie. Stuttgart, 1972.

BInenveld, J.M.W., C. Brinkgreve, A.J. Lamelja, H.F.M. Rerterg, P. Vandermeersch, C.P. Vos \& J. Vijgelar: Een poychiatrich verleden. Utt de geschledents van de psychiatrie. Batr, 1982 .

B1j1, R. J. Mastboon: Van behoefte naar vraag. Epldemiologlach onderzoek en regionale verdeling van AGGZ-capaciteit beperkingen en mogelijkheden. NCGV-reeks $89,1986$.

Boas, F.: Anthropology and modern Life. New York, 1962.

Bos, T. van den, A. Lau-IJzerman, J.D.F. Habbema \& P.J. van der Maas: Ongezondheld in de grote stad (I \& II). Medisch Contact, $1981 ; 12$ \& $13: 335-340,385-389$.

Borma, A.: De ekologische benadering in de psychiatrie. Tijdschrift voor Psychiatrie, 1975a;17; 4: 273-282.

Bosma, A.: De ruimtelijke spreiding van klinisch psychiatrische patienten in Nifmegen. Tijdschrift voor Psychiatrie, 1975b; $17 ; 4$ : $273-282$. 
Brinkgreve, C., J.H. Onland A. de Swaan: Soclologle van de psychotherapie 1. De opkomst van het psychotherapeutisch bedrijf. Utrecht, Antwerpen, 1979.

Erimkgreve, C.: Psychoanalyge in Nederland. Een vestingsstrijd. Amsterdam, 1984.

Brook, 0.H.: Heropnemingen in de Algemene Paychlatrische Ziekenhuizen in de periode 1970 tot en met 1980 . Tijdschrift voor Psychiatrie, $1984 ; 26: 500-525$.

Brook, F.G., H.J.F.R. Hamers: GGZorg gepeild. Een vergelijkend onderzoek met behulp van twee Registers voor de Geestelljke Volkagezondhe1d. Tijdschrift voor Psychiatrie, 1985; $27: 115-127$.

Brown, G.W. T. Harris: Social origins of depression: A atudy of psychiatrlc disorder in women. London, 1978 .

Bulhof, I.N.: Freud en Nederland. Baarn, 1983.

Busfleld, J.: Managling madness. Changing ideas and practice. London, 1986.

Cassel, J.C. Tyroler: Epidemiological studies of Culture Change. Archives of Envirommental Health, 1961 vol. 3; 7: 61.

Cassel, J.C.: Social science theory as a source of hypothesis in epldemiologic research. American Journal of Public Health, 1964; $54(1): 1482-1488$.

Casse1, J.C.: The Contribution of the Social Environment in Host Resistance. American Journal of Epldemiology, 1976; 104 (2): $107-123$.

Cohen, C.I. J. Sokolovsky: Schizophrenia and soclal networks: ex-patients in the inner city. Schizophrenia Bulletin, 1978; 4 : 546-560.

Cooper, J. N. Sartorius: Cultural and temporal variations in Schizophrenla. A speculation on the Importance of Industrialization. British Journal of Psychiatry, 1977; 130: 50-55.

Crombag, H.F.M.: De eeuw van het beleid. Intermediair, $198622 \mathrm{e}$ frg * 13-28 mart, $19-21,55$.

DeVries, H.W.: Introduction: Medicalization in perspective. In: $M$. DeVrles, R.L. Berg and M. Lipkin Jr,, eds., The use and abuse of medlelne, New York, 1982 .

DeVries, H.H., H.J.T.R. Hamers: Mental Health Care and Morbidity. Tifdschrift voor Sociale Gezondheidszorg, 1984; 12 : 504-506.

DeVries, M.H., H.J.I.R. Hamers, F. Sturmans: The use of the case register in econimizing epidemiological reaearch. In: Ten Horn, Giel, Gumblinat and Henderson (eds). Psychiatric Case Registers 1960-1985. Elsevier Sclence Publishers BV, 1986.

Does R., A. KonIng, L. Strijbosch \& L. Volovics: Syllabus. Data Analyse: exploratie en evaluatie. Capaciteitsgroep Medische Informatica en Statistiek. September, 1983.

Dohrenwend, B.P.: Addendum: B.S. Dohrenwend: Social status and responslbility for stressful life events. In: C.D. Splelberger \& I.G. Sarason (eds.), Stress and Anxiety. Washington, New York, London, 1986. 
Dormaar, H., C. DIflman, H. deVrles: Consensus in mental health care: a measure of the therapeutic relationship related to outcome. Perspectief, $1986 \mathrm{Jrg} 4$; no. $2: 3-28$.

Drop, H.: Arbeldsverdeling, nomatleve integratle en typen van afwifkend gedrag. Maastricht, 1979 .

Duncan-Jones $P$. \& S. Henderson: The use of a two-phase design in a population survey. Social Psychiatry, 1978; $1: 231-237$.

Dunham, H.H.: Community and achizophrenia: an epidemiological analysis. Detrolt, 1965.

Bdgerton, R.B.: Traditlonal treatment for mental iliness in Africa: a review. Culture Medicine Psychiatry, 1980; 4: 167-189.

E11as, N.: Het civilisatieproces. Soclogenetische en paychogenetische onderzoekingen. Deel. I en II. Utrecht, Antwerpen, 1984.

Everitt, B.S.: The analysis of contingency tables. London, 1977.

Fabrega, H. Jr.: The Idea of Medlcalization: an Antropological Perspective. In: M.W. deVrles, R.L. Berg M. Lipkin jr. (eds.). The Use and Abuse of Medicine, New York, 1982.

Farris, R. E Duham, H.: Mental Disorders in urban areas. Chicago, 1939; Phoenix Books, London, 1965.

Pavazza, A.R. E A.D. Faheem: Themes in Cultural Esychiatry. An annoted bibliography, 1975-1980. Columbia, Londen, 1982.

Tavazza, A.R. Letter in Trancultural Psychiatrio Research Review, 1986; vol. XXIII: 186-87 n.a.v. DiNicola (1985).

Friedman, G.D.: Primer of epidemiology. New York, HeGraw-H111, 1974.

Foucault, M.: Madness and Clvilization, A History of Insenity in the Age of Reason, New Tork, 1965.

Gardner, B.A., H.C. Mlles, A.K. Bahn and J. Romano: All psychiatric experience in a community. A cumulative survey: Report of the first year's experience. Archives of General Psychlatry, 1963; 19: 369-378.

Gardner, B.A., H.H. Babigian: A longitudinal comparison of psychiatric service. American Journal of Orthopsychiatry, 1966; $36,818-828$.

Gie1, R., G.H.H.H. ten Horn: Een psychiatrisch register als basis voor planning. Tijdschrift voor Sociale Geneeskunde, 1976; 54 : 148-153.

Glel, R.: Over de clasiffcate in diagnostisch opzlcht van de clienten. Afd. Sociale Rsychiatrie, RUGroningen, 1978.

Giel, R., G.H.M.M. ten Horn: The thruth about psychiatic morbidity. Acta psychiatrica Scandinavica, 1980, Suppl. 285; 62: 30-40.

Giel, $R$ G.H.M.M. ten Horn: De verhouding tuseen hulp-vraag en -aanbod: risicogroepen in de GGZ. Tijdschrift voor Paychlatrie, $1981 ; 23: 504-521$.

Giel, R.: Warom een psychlatrische dianose? Een beknopte Inleiding in het medisch wodel en in andere modellen. Alphen a.d. Rifn/Brusse1, 1982. 
Goldberg. D.: Manual of the General Health Questionaire. Slough, National Foundation for Educational Research, 1979.

Goldberg, D. $f$. Huxley: Mental Illness in the Community: the pathway to paychiatric care. Tavistock, London, 1981 .

Graaf A.C. de, G.H.H.M. ten Horm: Paychiatriache patienten-registers In Engeland, Schot1and, Denemarken en Nederland anno 1975. TiJdachrift voor Soclale Geneeskunde, 1975; 53 : 829.

Grintem $T$. v.d.: De vorming van de ambulante Geestelijke Gezondheidzorg. Een historlach beleldsonderzoek, Baarn, 1987.

Gunateren, H.R. : : The Quest for Control. John Wiley song, London, 1976.

Habbema J.D.F., T. van den Bos, A. Lau-IJzerman \& P.J. pan der Maas Onderzoek naar verschilien in sterfte, zlekenhulsopnamen en langdurige arbeldsongeschiktheld tussen buurten in Amsterdam. Tijdachrift voor Soclale Geneeskunde, 1980; $58: 101-106$.

Haberman: Analysis of quantitative data. Vol. 2. Academic Press, New York, 1979.

Habermas, J.: Theorle des kommunkativen Handelns, Band 1. Suhrkamp Verlag, Frankfurt am Main, 2e druk, 1982.

Habermas, J.: Theorle des kommunikativen Handelns, Band 2 . Suhrkarap Verlag, Frankfurt an Maln, 2e druk, 1982.

Hafner, H., H. Reimann, H. Imich \& H. Martini: Inzidenz Seelicher Erkrankungen in Mannheim. Social Psychiatry, 1965 Vol.4: 126-135.

HEfner, H. \& $J$. Klug: The Impact of an expanding community mental health service on patterns of bed usage: evaluation of a four-year period of Implementation. Psychological Medicine, 1982; 12: $177-190$.

Halfena, R.J.G.: Locus of Control. Beheersingsorientatie in relatie tot zlekte en gezondheidsgedrag. Maastricht, 1985 .

Hamera, H.J.F.R. \& F.G. Brook: De GGZ in het noorden en zuiden des lands in 1981. Tijdachrift voor Psychiatrie, 1986; 4: 254-266.

Hamera, H.J.F.R., M.A.J. Romme, G.A.M. Drlessen: Het (on)bedoelde Bebruik van meerdere GGzorg-voorzieningen. Tijdschrift voor Soclale Gezondheldszor, 1985, 13: 506-511.

Hamers, H.J.F.R., G.A.M. Driessen: Risico op GGZorg. Tljdschrlft woor Soclale Gezondhe1dszorg, 1986; 563-567.

Hamers, H.J.T.R.: Onderzoek en privacy van een dilemma. Perspektief, jund 1984 .

Hamers, H.J.R.R.: 24-uurs Opvangpost van akute en psycho-soclale en psychiatrische krises in de regio Mastricht. Tijdschrift voar Soclale Gezondheldszorg, $1983 ; 61$ (21): 802-805.

Hamera, H.J.F.R., M.A.J. Rome, M.W. deVries: Resistance, Privacy and Technology: comments on the negoclations of the case register in Mastricht (me1 1985) In: ten Horn, Giel, Cumblinatt and Henderson (eds). Psychlatric Case Registers 1960-1985. Elsevier, 1986.

Hankiss, B., R. Manchin \& L. Fustos: The Role of Value Deficiencies In Primary Health Care Recording Systems. In: Lipkin, $M$. $K$. Kupka, Poycho social Factors Affecting Health. New York, 1982. 
Haveman, H.J.: De frequent opgenomen psychlatrische patidnt draalt de draaldeur selectief (II). Tijdschrift voor Psychiatrie, 1980; 22 : 267-277.

Helgason, I.: Prevalence and Incldence of mental disordrers estimated by a health Questionnaire and a psychiatric Case Register. Acta Psychiatrica Scandinavica, 1978; 58: 256-266.

Helgason, T.: The epidemlology of Alcohol Abuse. Nordisk Medicine, $1984 ; 99: 290-294$.

Henderson, S., D.G. Byrne \& P. Duncan-Jones: Neurosis and the Soclal Environment. Canberra, 1981 .

Hodiamont, $\mathbf{P}$. $\mathbf{B}$. ter Helne, $\mathbf{P}$. Hegendaal, J. Furer, P. Peer: Psychiatrische en psychosociale problematiek: overeenkomst en verschi1. Maandblad Geestelijke Volkggezondheld, 1986; $2: 128-144$. Hoek, H.W., F.G. Brook, R. Giel \& G.H.H.H. ten Horn, Anorexia Nervosa. Tijdschrift voor Psychlatrle, 1984; $26: 736-744$.

Hondrich, K.0.: Menschliche Bedurfnisse und Sociale Steuerung.

Reinbek be 1 Hamburg, 1975.

Horn G.H.M.M. ten: De dienstverlening aan mensen met alcohol- of drugsproblemem door instellingen van de GGZ. Tijdschrift voor Soclale Geneeskunde, 1976; 54 : 806-809,840.

Horn G.H.M.M. ten, R. Giel: Patronen in het netwerk van de geestelifke gezondheidszorg. Mandblad Geestelijke Volksgezondheid, $1978 ; 1: 23-34$.

Horn ten G.H.M.M.: Nazorg geeft kopzorg. Maandblad Geestelijke Volksgezondheid, $1982 ; 12: 1279-1294$.

Horn tem G.H.M.H.: Kortdurende opnamen: elgen taken voor de PAAZ en het psychiatrisch ziekenhuis. Het ziekenhuis, 1982 vol. 12; 11: 601-603.

Hymes, D. (Ed.): Reinventing Anthropology. Vintage, Random House, New York, 1974

I11ich, I.: Medical Nemesis: The Expropriation of health. New York, 1976.

Jaobs, H.: RIGGtingen '83. Een Inventarisatie van samenwerkimgsverbanden tussen extramurale, semimurale en Intramurale GGZvoorzieningen, Utrecht (NCGV-reeks 59), 1984.

Jonkman, J.: Apart afrekenen. De verhouding tussen de financieringswijzen in de geestelifke gezondheldszorg en het streven nar inhoude 11 jke samenhang. NCGV-reeks 63 , 1984.

Kapteyn, P.: De speeltuin Nederland. Zwolle, 1985.

Kiev, A.: Transcultural Esychiatry. Middlesex, 1972.

Rleinman, A.: Ratients and Healers in the context of Culture. Berkeley, Universtty of California Press, 1980.

Kleinman, A.: Medicalization and the Clinical Praxis of Medical Syatems. In: M.W. deVries, R.L. Berg M. Lipkin Jr. (eds), The Use and Abuse of Medicine, New York, 1982.

Koot, T H. Stegerhoek: Zorgzame samenleving tussem recht en w1. Harmonisatleraad Welzijnsbeleid. "-Gravenhage, 1986. 
Langbein L.I. A A.J. LIchtman: Ecological Inference, Beverly HIIIs, London, 1978 .

Lasch, C.: Haven in a Heartless Horld: The Family Beselgned, New York, 1977 .

Lasch, C.: On Hedicalization and the Triumph of the Therapeutic. In: H.W. deVrles, R.L. Berg \& H. Lipkin Jr. (eda). The Use and Abuse of Modleine, Nev Tork, 1982 .

Lamalre $T .:$ over de warde van kulturen; een inleiding in de kulturfilosofie. Ambo, Barn, 1976.

Levin, B.L., J.H. Glaaser, R.B. Roberta: Changing Patterns in Mental Health Service Coverage ithin Health Haintenance Organizations. American Journal of Public Health, 19.; 74: 453-458.

Luhman, N.: Aufklitungen I, Aufsatze zur theorle aozialer systeme. Opladen, 1970 .

Luhman, N.: Soclologische AufkIlirung II, Aufsatze zur Theorie der Gesellschaft. Opladen, 1975.

Haas F.J. V.d. S J.D. Habbema: Standaardiseren van ziekte- en sterfteciffer: mogelijkheden en beperkingen. Tifdschrift sociale Geneeskunde, $1981 ; 59$ (8): $259-270$.

MacMahon, B., T.F. Rugh: Epidemlology: principles and methods. Boston, Little, Brown, 1970.

Mattes, J.A.: The optimal Lenght of Hospitalization for Psychiatric Patients: A review of the Literature. Hospltal and Communty Psychiatry, 1982; 33 (10):824-828.

Haslow, A.H.: Toward a paychology of being. New York, 1968.

Milbrath L.W. : Indicators of environmental quality and quality of 11ve. Reports and Papers in the social sciences, 38, Unesco, 1978: $32-56$.

M111er, P. J.G. Ingham: Friends, confidants and aymptoms. Social Psychiatry, 1976; 11:51-58.

Hok, A.I.: Beroepen in akt1e. Meppe1, 1973.

Morgenstern, H.: Uses of ecologlc analysis in epidemiologic research. American Journal of Public Health, 1982, 72: 1336.

Mefe, J.A., S.L. Mcra11, T.D. Cleaveland: Paychiatry and medicine in US: Interpreting trends in medical speciality cholse. 1987.

Nelisen, N.J.M.: Grondbeglaselen van de saciale ecologle, Utrecht, Antwerpen, 1972 .

Norus 18, M.J.: SPSS-X Advanced statistlcs gulde. New-York, 1985.

NLuwe Nota Geestelijke Volksgezondheid. Handelingen Tweede Kamer $1983-1984$, stuk 18.463, no.1-2, 1984 .

Offerhaus, R.: Nadere analyses van de st. Bavo bevolkingsenquete. 1984 .

Oosterbaan, H. W. Zeldenrust: Geschelden wegen. Soclale Netwerken, proto-professionalisering; psychische problemen en hulpzoekend gedrag bij geschelden mensen. Utrecht (NCGV-reeks 84), 1985.

Ormel, J.: Moelligk met leven of een moeilifk leven. Een vervolgonderzoek naar de invloed van psychosociale belasting op het 1 bevinden van drlehonderd Nederlanders. Groningen, 1980 . 
Orme1, J. R. Glel: Omvang, beloop en behandeling van psychische stoornissen bif de hulsarts. Een literatuur-overzlcht pleldooi voor de ontwikkeling vam een beslissingsschema op multiaxiale basis. Tijdschrift voor Psychiatrie, 1983: 688-710.

Peters, F.G.: Cultuur in of aan organisatles; lets bljzonders? Technische Universiteit Twente Enschede, Jan. 1986.

Prince, R. $\mathbf{E}$. Teheng-Laroche: Culture Bound syndromes and International Disease classifications. Culture, Medicine Psychlatry, 1987; 11: 3-19.

Rants, G; R. Sanderman, J. Orme1: Ongelijke kansen op geestelljke gezondheid(szorg). Verilag van de geestelljke gezondheld in Nederland. Groningen, 1987.

Redilch, F. and S.R. Wellert: Trends in American Mental Health. American Journal of Psychtatry, 1978; 135: 22-28.

Regler, D.A., I.D. Goldberg and C.A. Taube: The facto Us mental health services system, a public health perspectlve. Archives of General Psychiatry, 1978; 35 : 685-693.

Regier, D.A., J.K. Myers, M. Kramer, L.N. Robins, D.G. Blazer, R.I. Hough, W.W. Baton, and B.z. Locke: The NIMH Epidemiologic Catchment Area Program. Archives of General Psychiatry, 1984; 41: 934-941.

Rome, M.A.J., H. Kram, R. Rottevel: Wat Is sociale psychiatrie? Een inleiding. Alphem a/d Rijn, Brussel, 1981.

Rome, M.A.J.: Samenwerken in de Geestelijke Gezondheldszorg; een pleidool tegen kategoraal psychiatrische zorg. Samenwerking in de Geestelijke Gezondheidszorg Gent, 1982 (25-42).

Romme, M.A.J. (red): Geestelifke Gezondheidazorg. Voorzieningen, werkwijzen, doelgroepen, medewerkers, ontwikkelingen, finamciering, omvang. Alphen a/d Rijn, Brussel (2e herziene druk), 1984.

Romme, M.A.J.: Bedenkingen bij de regionale geestelijke gezondheidszorg in Nederland. Tijdschrift voor Psychlatrie, 1985; 27 (7): $439-446$.

Romme, H.A.J.: Social Psychiatry in Zimbabwe or the interplay of culture and psychosocial disorders. Te verschifnen in The International Journal of Social Psychlatry, 1987.

Rotteveel, R., H. Uffing, N. de Vries: Resoclaliatie in de GGZ in de Westelijke Mijnstreek; een samenwerkingsprojekt. Rapport voor het Preventiefonds. Me1, 1984.

Rotter, J.B.: Generalized expectanties for internal versus external control of reinformcement. Psychological Monographs, 1966; 80: $1-28$.

Sartoriug N.S., A. Jablensky R. Shapiro: Cross-cultural differences in the short-term prognosis of schizophrenic psychoses. Schizophrenia Bulletin, $1978,4: 102-113$.

Schagen, S.: Het effect van psychotherapie. Meetbarheld en resultaten. Deventer, 1983.

Schagen. S.: De praktijk van de psychotherapie. Deventer, 1985. 
Se11giman, M.E.P.: Helplessness: On depression, development, and death. W.H. Ereeman, San Francisco, 1975.

Shepherd, M., B. Cooper, A. Brown and G.H. Kalton: Psychiatric 11 iness in general practice. Oxford Unlversity Rress, London, 1966 .

Smith, H.L., G.V. Glass \& Th.I. Miller: The benefits of psychotherapy. Baltimore, 1980 .

Soclaal Cultureel Planbureau: S.C.P. cahler no.14, 1980.

Srole, L., T.S. Langner, S.T. Hichael, F. Kerkpatzlck, H.K. Oplen \& T.A.C. Rennie: Mental Health in the Metropolis. The Midtown Manhattan Study (edited by L. Srole \& A.K. Fisher). Nev York (revised and enlarged edition), 1978.

stokola, D.: A Congruence Ana1ysis of Human Stress. In: Splelberger, C.D. I.G. Sarason (eds), Stress and Anxiety. Vol.10. A source book of Theory and Research. Washington, New York, London, 1986.

Sturmans, R.: Epidemiologie: theorile, methoden en toepassing. Dekker en Van de Veght, Nijmegen (2e druk), 1983.

Swaan, A. de, R. $\nabla$. Genderen $\boldsymbol{F}$. Kense: Sociologie van de pgychotheraple 2. Het spreekuur als opgave. Utrecht, Antwerpen, 1979.

Swaan, A. de: De mens is de mens een zorg. Amsterdam (3e herziene druk), 1984 .

Szasz, T.S: The Myth of Mental Illness: Foundations of a theory of Personel Conduct, Wew York, 1961.

Tukey, J.W. Exploratory Data Analyses. Reading, Massachusetts, 1977.

Tpema, R. F. de Haan: Verdelen naar behoefte. Nederlands Centrum Geeste 1 ijke Volksgezondheid, Utrecht, 1983.

Verhey, F.H.H.: Langzame hersenpotentialen en gemeten gedrag. Leiter-Nypels, Mastricht, 1981.

Verdonk, A.: Stadsbuurten, de ene is de andere miet. Deventer, 1979.

Vagenberg, H. . Rangorde van sociale achterstand in de buurten van de gemeente Mastricht en van de gemeente Mastricht in vergelijking met een antal Limburgse en Nederlandse gemeenten. Dienst Weldijngzaken Masitricht, 1982 .

Weber, W. Wlrtachaft und Gesellschaft. Grundriss der verstehende Sociologie. (Studlenausgabe) se gereviseerde oplage door Wincke Iman, J.C.B.: Mohr, Tubingen, 1972.

Wearden-DiJkatra J.R. van a R. Giel: Mededelingen uit het centrale Patiden-Register voor psychlatrische ziekenhuizen en undversiteitaki inieken. Tijdschrift voor Psychiatrie, 1974; 16: 453.

Weerden-Dijkstra, J.R. van R. Giel: Risilicogroepen voor psychiatrische opmame. Tijdschrift voor Psychiatrie, 1975; $41-47$.

Weyerer, S., B. Maylath, M. Pfelger-Kurda, B. Krum, G.H.M.M. ten Horn: Die stabilitut der skologischen verteilung psychiatrisch behandelter Ersterkrankungen in der stadt Mannheim. Nervenheilkunde, $1987 ; 6: 14-22$. 
Whiting, J.: Methods and problems in cross-cultural research. In: G. Lindzey and E. Aronson, eds., Handbook of social psychology, Vol. 2, 2nd ed.: 693-728. Addison-Wesley, Reading (Mass.), 1968.

wiken, H.: Hacht und psychlatrische etikettlerung. Rolner Zeitschrift fur Soziologie und Sozial Psychologie, 1973a; 25: 274-285.

W11ken, M.: Hospitalisationsristko und Gemeindestruktur. Kolner Zeltschrift fur Soziologie und Sozlal Psychologle, 1973b; 25 : 319-336.

Wing, L., J. Ving, A. Hailey, A. Bahn, H. Smith and $J$, Baldwin: The use of psychiatric services in three urban areas; an international case register study. Social Psychiatry, 1967; 2: 158-166.

Wing, J.K. a.o.: Camberwell Cumulative Psychiatric Case Register. Part I Aims and Methods. Social Psychlatry, 1968; 3: 116.

Wing, J.K. \& A. Hailey: Evaluating a community psychlatric service: Camberwe11 Register 1961-1971. Oxford Press, Oxford, 1972.

Wing, J.K., A. Halley: Reported prevalence, In: $L$. Wing and A. Hailey, eds. Evaluating a community psychiatric service. London, Oxford University Press, 1972.

Wing, J.K., J.H. Mixon, S.A. Mann J.P. Zeff: Rehability of the PSE (nineth edition) used in a population study. Psychological Medicine, $1977 ; 7: 505-516$.

World Health Organisation: Psychiatric case registers, report on a working group. Mannheim 5-6 May, 1983. 


\section{DANKMOORD}

Het wetenschapsgebied sociale psychlatrle ls groot; werken in je eentje an onderzoek op dit terrein is bijna per definltie onmoge11jk. Dit proefschrift is dus bepald niet het werk van en persoon. Temeer daar het verwerkte empirisch material ult een psychlatrisch casusregister gedestilleerd is; concreet betekent dit, dat vele medewerkers werkzaam in GGZ-voorzleningen een bijdrage "op afstand' aan dit proefschrift leverden.

Een aantal persomen is op de een of andere wijze nauw betrokken bij de werkzamheden die en voorlopig elndpunt vonden in deze bundel. Prof.Dr. M. Romme is alnds 1980 mijn mentor in het vakgebied sociale psychiatrle en onder zijn begelelding kwam het reglater tot stand. Bovendien stimuleerde hij mij een antal register-deelstudies bijeen te brengen. In dat proces -en vooral wat betreft de theoretische onderbouwing van het empirisch material- heb ik in mifn tweede promotor Prof.Dr. H. Philipsen een goede gesprekspartner gevonden, wardoor mij enkele dwalingen besparard bleven.

Prof.Dr. R. Giel mag national en international als de 'peetvader' van psychiatrische casusregisters gezien worden. Hij heeft een niet te onderschatten rol gespeeld in het tot stand brengen van het 'zuldelifk' register. In het vervolg hierop heeft hij zifn rol als referent nauwgezet en ter zake ingevuld. Zonder Prof.Dr. F. Sturmans en Prof.Dr. M. deVrles had dit proefschrift moellijk afgerond kunnen worden. Immers, behalve hun adequate reactie als referent, hebben belden - leder vanuit een andere positie-bijgedragen tot het ocheppen van voorwarden wardoor enerzijds het register als continu te onderhouden 'data-base" in stand kan blijven en anderzijds het psychiatrisch-epidemiologisch onderzoek gestimuleerd wordt.

Het opzetten van het register werd mogelijk gemakt door een subsidle van het Ministerie van Welzijn, Volksgezondheid en Cultuur. Van de contacten met dit Ministerie is met name de aktieve rol van Mevr.Drs. A.C. de Grat te noemen: de plaatsvervangend hoofdinspecteur voor de

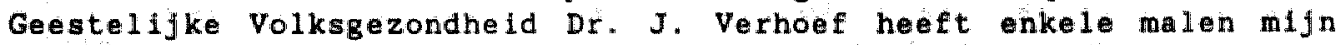
gemoedstoestand - In mineur als lets angaande het regleter minder goed verliep- weten te verbeteren. Eenzelfde rol heeft Dr. T. v.d. Grinten -wellicht ongeweten- nogal eens in de landelijke begele1dingscomissie op zich genomen.

De collega's te Groningen van de afdeling Sociale esychiatrie aldar ben Ik veel dark verschuldigd. Dit geldt in het bljzonder voor Hevr. Dr. G. ten Horn en Drs. F. Brook. Ik hoop dat de samenwerking tussen het zuiden en het noorden, liefst tezamen met bultenlandse registerteams, verder gelntensiveerd wordt en er nog vele vergelifkende studies uitgevoerd mogen worden. Aan stimulans hiertoe zal vooral dankzij Dr. ten Horn geen Bebrek zijn.

Bif de opzet van het register kreeg ik ondersteuning vanuit de vakgroep Medische Soclologie door een actieve bljarage van Brof.Dr. G. Saenger, terwijl het MHCR in die beginfase een facultalre plek in 
een deelproject onder leiding van Prof.Dr. M. Drop kreeg. Enkele recente exploitatieproblemen konden soepel verholpen worden, omdat een van de huldige MHCR-projecten organisatorisch tot het deelproject "aspecten van de gezondheidszorgbeleid bij overheid en Instelling" ander lelding van Dr. I. Mur behoort. Van Prof.Dr. J. Bremer mocht ik enkele muttige tips ontvangen betreffende hoofdstuk 2 .

Vanult het Memic waren Mevr. M. Kruljen, Dr.Ir. C. Limonard en dhr. L. Ploumen actief anwezig on het reglster mede van de grond te tillen. Ook ben ik het Memic dankbaar voor de levering van de noodzakellfke referentiegegevens op populatieniveau. zo werden de "buurtdata" verkregen met hulp van Dra. F. Nijhuis (Memic), Drs. H. v. Wagenberg en Drs. G. Rutten (belden van de afdeling Onderzoek en Statistlek van de gemeente Mastricht).

Dit proefschrift kon groeten op een werkvloer, warop in de loop der Jaren diverse personen meer dan verdienstelifk waren. Dat waren in het bifzonder enkele medewerkers bij de vakgroep Sociale Psychiatrie -Mevr. J. Lasker als onderzoeksasistente en Mevr. L. van Mameren, Mevr, L. Vissers en Mevr. C. Kerkhofs als administratief medewerksters- die hun onontbeerlijke bifdragen leverden. Vanaf eind 1983 kreeg het reglsterteam versterking in de persoon van Drs. G. Driessen; vanaf dat moment kwam een gestage onderzoeksproductie op gang.

Indlen $u$ met mif van oordeel bent dat het Nederlands in dit dankwoord gebrekkiger is dan het overige talgebrulk dan zal lk u verklappen dat dit verschil te danken is an Mevr. S. Escher. zif las (en verbeterde) het dankwoord niet, de rest van de tekst wel: ook Drs. H. Kraan en Drg. L. Meertens hadden gedurende de afgelopen periode een meer dan gebruikelijke aandacht voor mijn mederlands. Wat betreft het Engels taalgebruik ben ik dank verschuldigd an Mej. C. Dijkman.

Howel de omvang van de secretariele ondersteuning met het jar terug blifkt te gaan, ben ik de dames Habets, Van den Boorn en Soute voor enige crisisondersteuning dankbar.

Deze studie had niet ultgevoerd kunnen worden, indien niet bijna alle GGZ-patiknten in deze regio goedkeurde dat hun gegevens voor het reglat werden verwerkt. Dat zil hilertegen niet massal protest antekenden was mede te danken an de 1fze warop het MHCR zifn plasts in de GGZ kreeg. Daarvoor ben ik vele GGZ-medewerkers, hulpverleners, beleldsmedewerkers, atafleden en adminlstratieve medewerkers dankbaar. In het bljzonder il ik hier de heren Vrijlandt Hilberink, Tans, Berden, Griens, Vroemen en Narimx noemen. Ook met de leden van de Raed van Toezicht is -ondanks hun critische taakinvulifng- in de loop der jaren en constructieve relatie tot atand gekomen.

Dat het schrijven van een proefschrift ook prive enkele gevolgen blijkt te hebben, was u als lezer warschijnlijk bekend. In het kader mijn priveleven enigszins to 'dekoloniseren' zal ik $u$ en openbare dambetulging an al diegenen die Ik prive te kort deed besparen. Wel zal Ik zorg dragen voor de noodzakelijke compensatile teneinde het evenwicht te herstellen. 
De auteur werd in 1949 in Mastricht geboren. Na de lagere school doorliep hij de H.B.S.-B an het Henric v. Veldeke College. In 1971 sloot hil een opleiding an de H.T.S. te Heerlen af. In de Jaren 1971-1973 vergrootte hij zijn kennis van de architectuur an de Academie voor Bouwkunst te Mastricht.

Vanaf 1973 tot 1979 studeerde hij westerse soclologle aan de $\mathrm{KU}$ te Nifmegen: de aandacht $\mathrm{ging}$ in het bijzonder ult nas stads-on organisatiesoctologie.

Na in 1979 korte tijd als beleidsmedewerker voor een samenwerkingsproject in de GGZ werkzaam te z\$jn geweest, startte hif in 1980 als profectmedewerker bij de toenmalige capaciteitsgroep Soclale Psychiatrie. Sinds medio 1985 is de auteur a de gelifknamige vakgroep als universitair docent verbonden.

De auteur $1 \mathrm{~s}$ gehuwd en vader van drie kinderen. 